Szegedi Tudományegyetem

Ásványtani, Geokémiai és Kőzettani Tanszék

Földtudományok Doktori Iskola

\title{
ALJZATI FLUIDUM-TÁROLÓK
}

KOMPLEX REPEDÉSHÁLÓZAT VIZSGÁLATI MÓDSZEREN ALAPULÓ HIDRODINAMIKAI ÉS HŐTRANSZPORT MODELLEZÉSE

Doktori $(\mathrm{PhD})$ értekezés

Vass István

Témavezetők:

Dr. M. Tóth Tivadar

tanszékvezető, egyetemi tanár

Dr. Szanyi János

tudományos főmunkatárs

Szeged 


\section{Tartalomjegyzék}

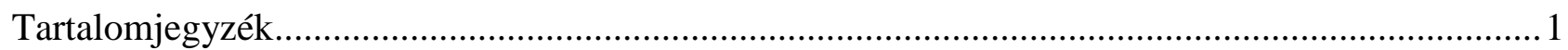

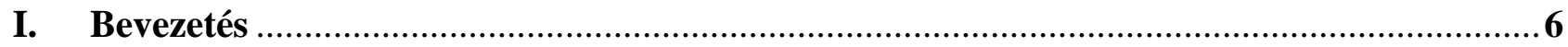

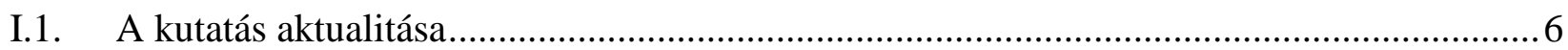

I.2. Problémafelvetés és a kutatási célok definiálása........................................................... 10

II. Repedéshálózatok vizsgálati lehetőségei ........................................................................ 12

II.1. Repedések, repedéshálózatok szerkezetföldtani jellemzése ........................................... 12

II.1.1 Törések kialakulása - tektonikai háttér..................................................................... 12

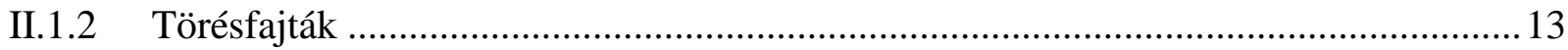

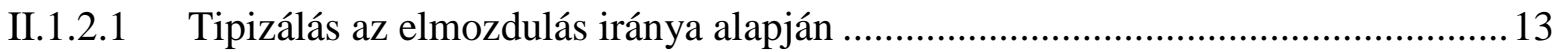

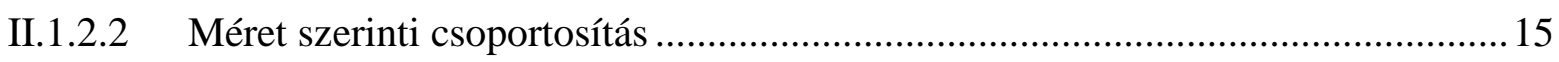

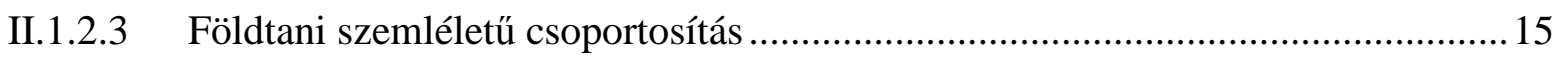

II.1.2.4 Kategorizálás a kitöltöttség alapján .............................................................. 16

II.1.2.5 A repedések fluidum-áramlásban betöltött szerepe ............................................ 17

II.1.2.6 Egyéb szempontok szerinti megkülönböztetés ................................................. 17

II.2. Matematikai jellegü megközelítés................................................................................... 18

II.2.1 Az egyedi törések parametrizálása.......................................................................... 18

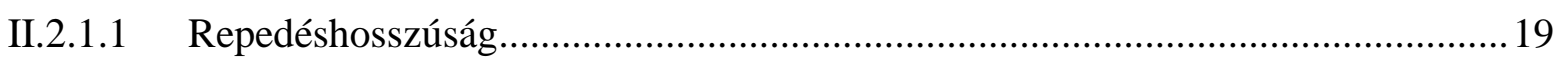

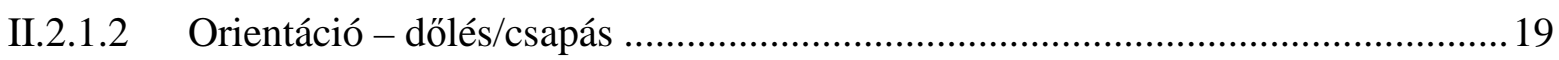

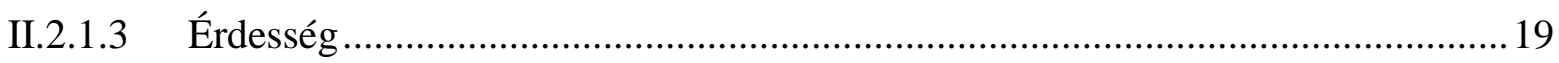

II.2.2 A repedés-paraméterek térbeli eloszlása..................................................................20

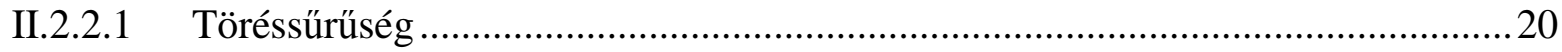

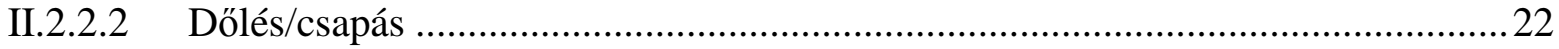

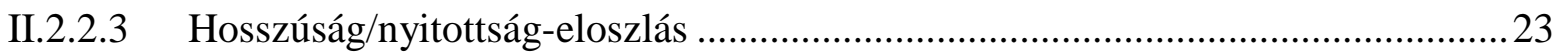

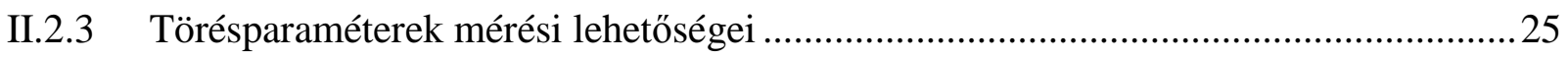

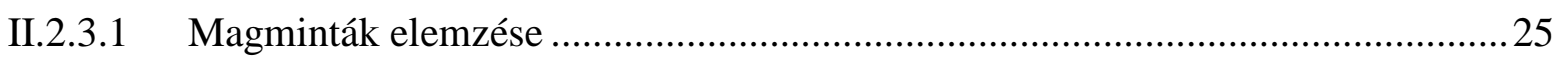

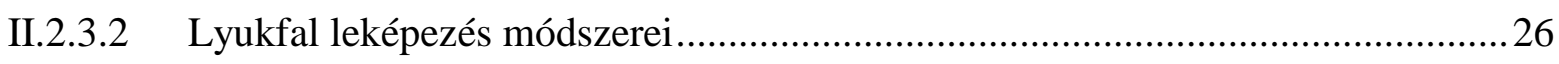

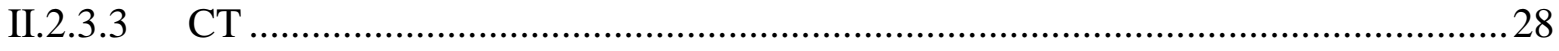

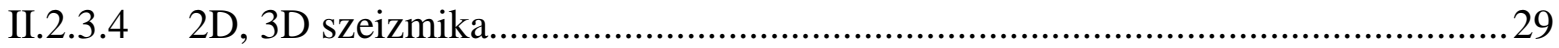

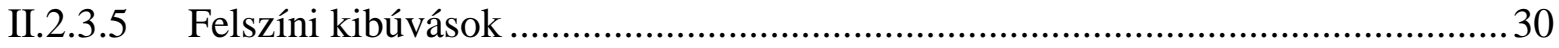

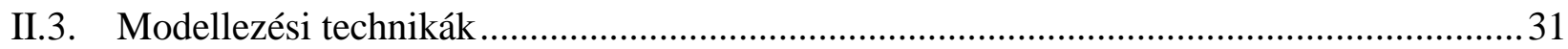

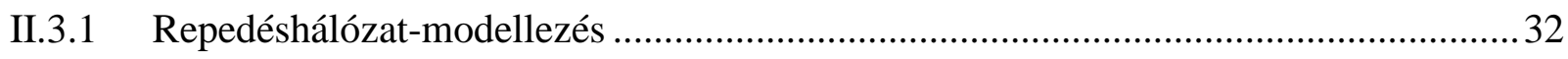


II.3.1.1 Repedéshálózat-modellezési megközelítések ...................................................33

II.3.1.2 A RepSim és az alkalmazott algoritmus ......................................................... 36

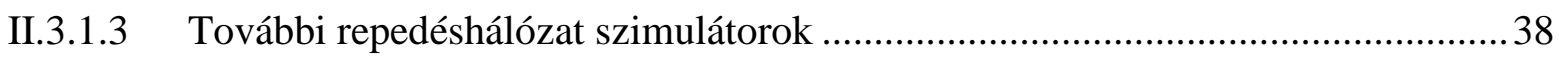

II.3.2 Porózus közeg modellezése - Felszín alatti vízáramlás és hőszállítás .........................39

II.3.2.1 A Processing Modflow környezet bemutatása ................................................ 41

II.3.2.2 A Feflow modellező szoftver bemutatása........................................................ 41

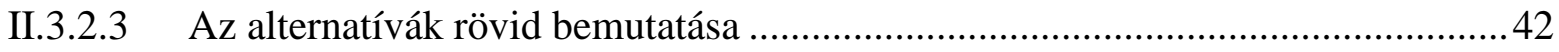

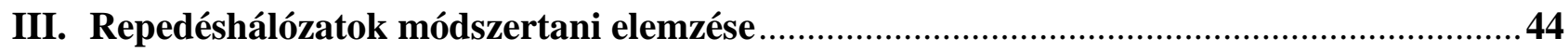

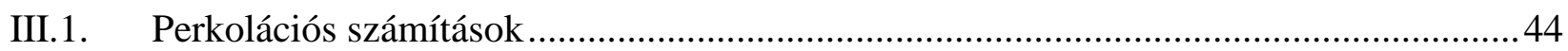

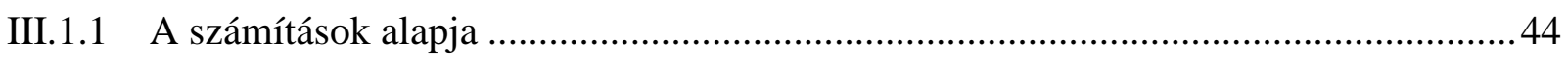

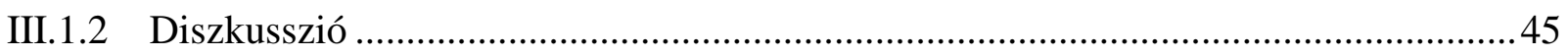

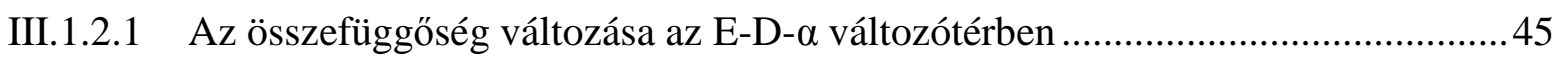

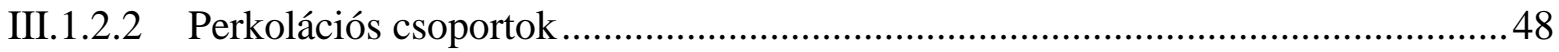

III.1.2.3 A perkoláció paraméter-függése .....................................................................50

III.1.2.4 Az E-D- $\alpha$ nomogramok alkalmazhatósága a Mórágyi gránit példáján ................52

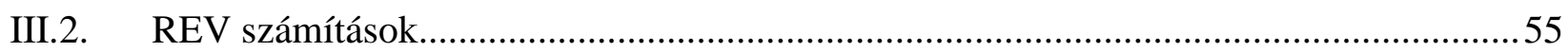

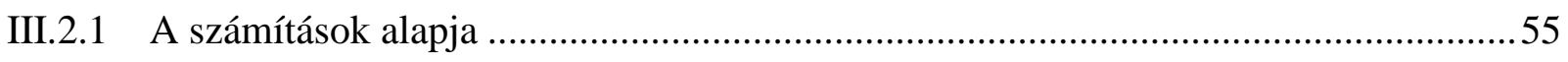

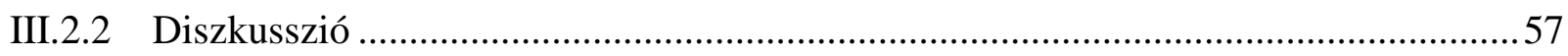

IV. Aljzati kristályos magaslatok hidrodinamikai és hőtranszport folyamatainak komplex

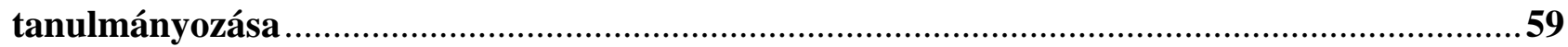

IV.1. Földtan - vízföldtan - geotermikus viszonyok …..........................................................59

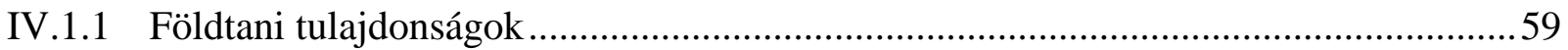

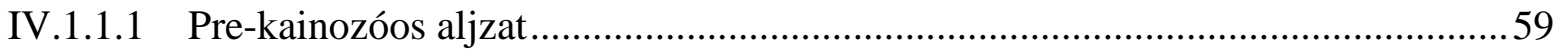

IV.1.1.2 Neogén és fiatalabb medencekitöltő üledékek ................................................61

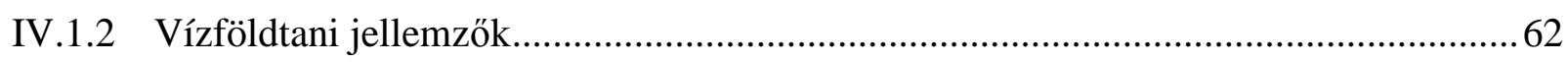

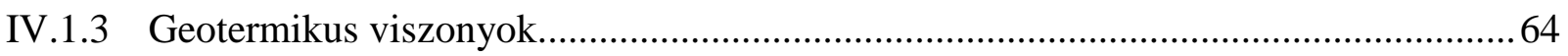

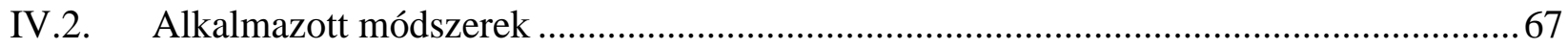

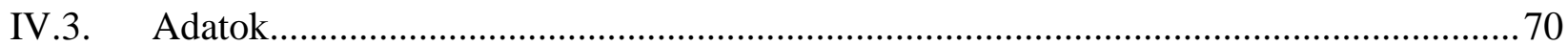

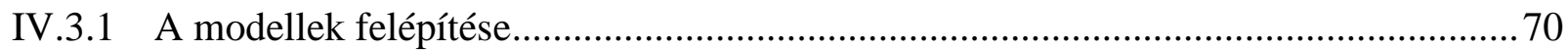

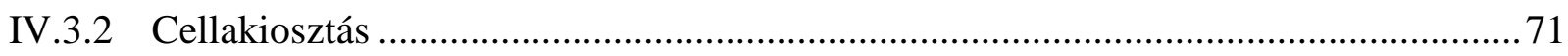

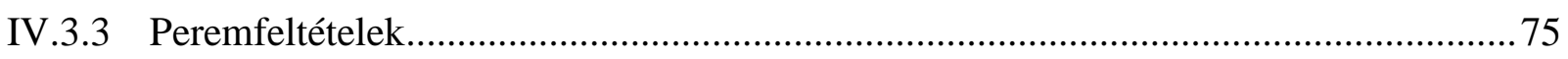

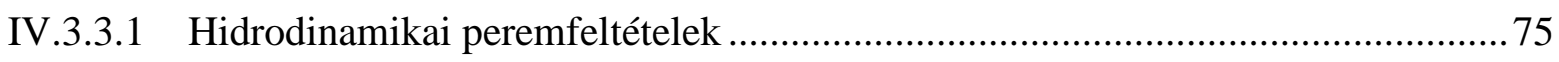

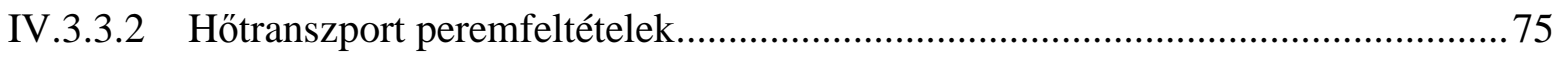




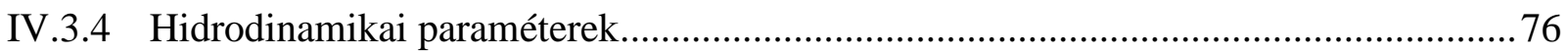

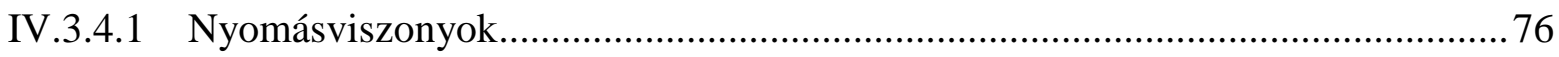

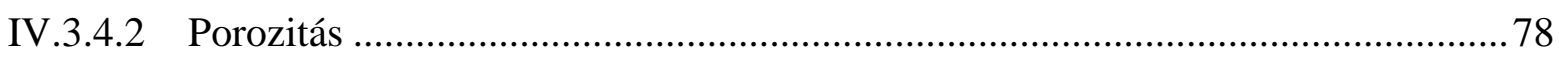

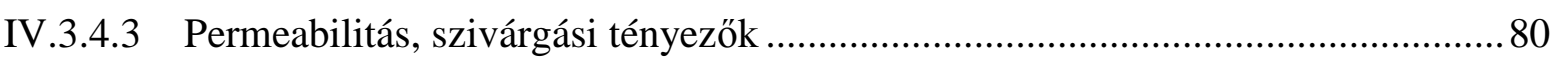

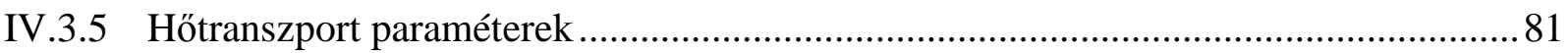

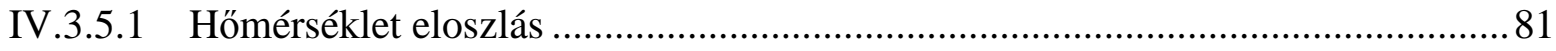

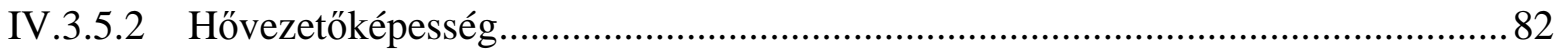

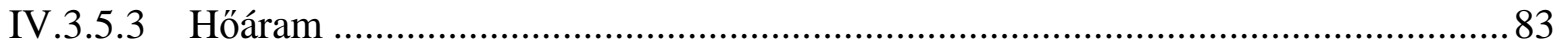

IV.3.5.4 A kőzet és a fluidum fajlagos hőkapacitása...................................................... 84

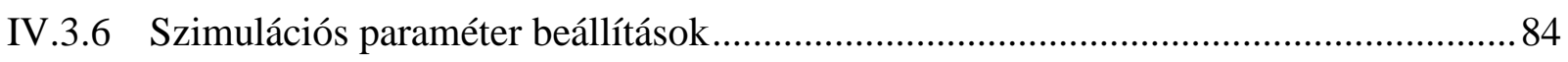

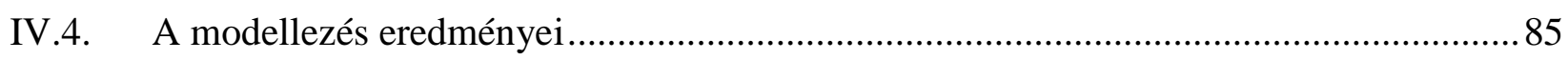

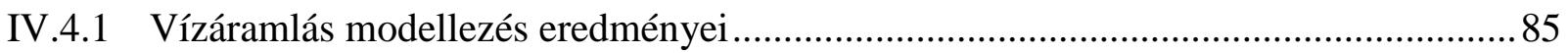

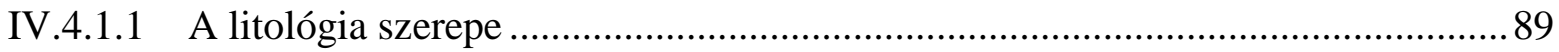

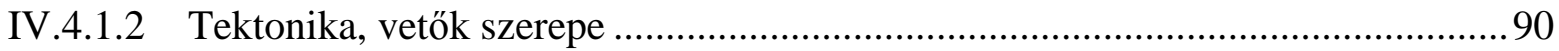

IV.4.1.3 Érzékenység vizsgálat - szivárgási tényező ..................................................92

IV.4.2 A hőterjedés modellezés eredményei..................................................................93

IV.5. A numerikus medellek összehasonlító értékelése......................................................... 100

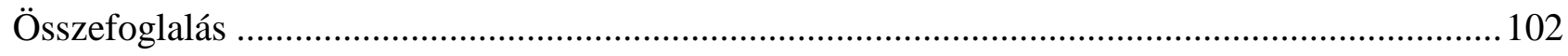

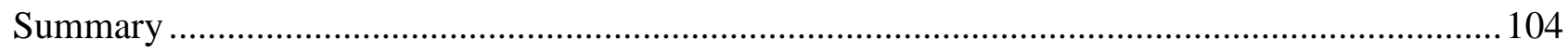

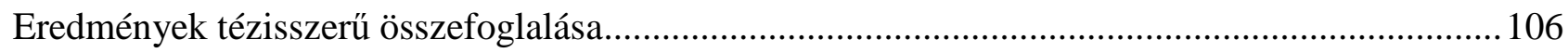

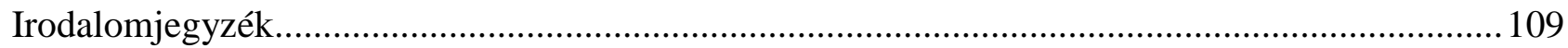

$A$. melléklet: a legnagyobb törésklaszter relatív méretének változása az $E, D$ és $\alpha$ paraméterek függvényében

$B$. melléklet: a legnagyobb törésklaszter relatív mérete szórásának változása az $E, D$ és $\alpha$ paraméterek függvényében

$C$. melléklet: a második legnagyobb törésklaszter relatív méretének változása az $E, D$ és $\alpha$ paraméterek függvényében

D. melléklet: a relatív dőlés számítására íródott Visual Basic program forráskódja.

$E$. melléklet: A véges differencia és végeselemes modellek hidrodinamikai és hőtranszport paraméterei

F. melléklet: a konduktív és konvektív hőterjedés arányának analitikus számítása az aljzati magaslat központi részén . 


\section{Szimbólumjegyzék}

\begin{tabular}{|c|c|c|}
\hline Jelölés & Leírás & Mértékegység \\
\hline$a$ & Törést reprezentáló korong nyitottsága & $\mathrm{mm}$ \\
\hline$A$ & Repedés nyitottsága & $\mathrm{mm}$ \\
\hline$\alpha$ & Közeg összenyomhatósága (II. fejezet) & $1 / \mathrm{m}$ \\
\hline$\alpha$ & Repedéscsoportok relatív dőlése (III. fejezet) & $\circ$ \\
\hline$B_{w}$ & Víz teleptérfogati tényezője & - \\
\hline$\beta$ & Fluidum összenyomhatósága & $1 / \mathrm{m}$ \\
\hline$c_{p}$ & Fajlagos hőkapacitás & $\mathrm{J} / \mathrm{kg}^{\circ} \mathrm{C}$ \\
\hline$\gamma$ & Nyomásgradiens & $\mathrm{bar} / \mathrm{km}$ \\
\hline$D$ & Repedésközéppontok fraktál dimenziója & - \\
\hline$D_{f}$ & Repedéshálózat fraktál dimenziója & - \\
\hline$E$ & Repedéshosszúság eloszlás hatványkitevője & - \\
\hline$h$ & Hidraulikus emelkedési magasság & $\mathrm{m}$ \\
\hline$I$ & Hőtermelés & $\mu \mathrm{W} / \mathrm{m}^{3}$ \\
\hline$k$ & Permeabilitás & $\mathrm{mD}, \mathrm{m}^{2}$ \\
\hline$k_{h}$ & Vízszintes permeabilitás & $\mathrm{mD}, \mathrm{m}^{2}$ \\
\hline$k_{v}$ & Függőleges permeabilitás & $\mathrm{mD}, \mathrm{m}^{2}$ \\
\hline$K$ & Szivárgási tényező & $\mathrm{m} / \mathrm{s}, \mathrm{m} / \mathrm{nap}$ \\
\hline$K_{h}$ & Vízszintes szivárgási tényező & $\mathrm{m} / \mathrm{s}, \mathrm{m} / \mathrm{nap}$ \\
\hline$K_{v}$ & Függőleges szivárgási tényező & $\mathrm{m} / \mathrm{s}, \mathrm{m} / \mathrm{nap}$ \\
\hline$l$ & Törést reprezentáló korong hosszúsága & $\mathrm{m}$ \\
\hline$L$ & Repedéshosszúság & $\mathrm{m}$ \\
\hline$\lambda$ & Hővezetési tényező & $\mathrm{W} / \mathrm{m}^{\circ} \mathrm{C}$ \\
\hline$M$ & Porozitás értékek átlaga & - \\
\hline$n$ & Repedések száma & $\mathrm{db}$ \\
\hline$N(L)$ & $L$ hosszúságú törések száma & $\mathrm{db}$ \\
\hline$N(s)$ & Törést tartalmazó cellák száma & $\mathrm{db}$ \\
\hline$p$ & Nyomás & bar \\
\hline$P$ & Perkoláció & $\%$ \\
\hline$P_{e}$ & Peclét-szám & - \\
\hline$q$ & Hőáram & $\mathrm{mW} / \mathrm{m}^{2}$ \\
\hline
\end{tabular}




$\begin{array}{clc}Q_{0} & \text { Felszíni höáram } & \mathrm{mW} / \mathrm{m}^{2} \\ \rho & \text { Fluidum sürüsége } & \mathrm{kg} / \mathrm{m}^{3} \\ s & \text { Rácselemek élhossza } & \mathrm{m} \\ S_{V} & \text { Vertikális föfeszültség } & \mathrm{MPa} \\ S_{H m a x} & \text { Maximális horizontális föfeszültség } & \mathrm{MPa} \\ S_{h m i n} & \text { Minimális horizontális föfeszültség } & \mathrm{MPa} \\ \varsigma & \text { Variációs koefficiens } & - \\ \sigma & \text { Porozitás értékek szórása } & - \\ \sigma_{1} & \text { Legnagyobb főfeszültség } & \mathrm{MPa} \\ \sigma_{2} & \text { Közepes főfeszültség } & \mathrm{MPa} \\ \sigma_{3} & \text { Legkisebb főfeszültség } & \mathrm{MPa} \\ T & \text { Hömérséklet } & { }^{\circ} \mathrm{C} \\ T_{0} & \text { Évi középhőmérséklet } & { }^{\circ} \mathrm{C} \\ T_{g r a d} & \text { Geotermikus gradiens } & { }^{\circ} \mathrm{C} / \mathrm{km} \\ \Delta T & \text { Hömérsékletváltozás } & { }^{\circ} \mathrm{C} \\ V & \text { Kocka rácselem térfogata } & \mathrm{m}^{3} \\ V_{f} & \text { Törést reprezentáló korong térfogata } & \mathrm{m}^{3} \\ \Delta V_{w p} & \text { Nyomásváltozás hatására bekövetkezö térfogatváltozás } & \mathrm{m}^{3} \\ \Delta V_{w T} & \text { Hómérsékletváltozás hatására bekövetkező térfogatváltozás } & \mathrm{m}^{3} \\ z & \text { Tengerszint feletti magasság } & \mathrm{m} \\ \phi & \text { Porozitás } & -\end{array}$




\section{Bevezetés}

\section{I.1. A kutatás aktualitása}

A földkéreg felső néhány kilométeres zónájában jelen lévő, térben és időben változatos összetételű fluidum alapvetően a kőzetek szemcseközi pórusterében vagy repedéshálózatában tárolódik. Bizonyos mélység alatt azonban, a pórustérre nehezedő litosztatikus nyomás és az ezáltal bekövetkező tömörödés hatására már csak olyan kőzeteket találunk, melyekben a repedéshálózat jelentheti a fluidum számára az egyedüli tárolási teret. A sekélyebb zónákban, ahol a szemcsék közötti pórusok a fő tárolók, ott a töréses elemek tulajdonképpen a szivárgás felgyorsításában játszhatnak fontos szerepet. A törések a legszélesebb mérettartományon jelen vannak, a szemmel nem látható mikro skálától a vetőkön keresztül egészen a kontinenseket átszelő nyírásos szerkezetekig.

A repedezett kőzettestek viselkedésének átfogó kutatása nélkülözhetetlen az olyan távlati célok szempontjából, mint a mélységi geotermikus kutatás, a víz és szénhidrogén bányászat, a veszélyes hulladékok és sugárzó anyagok elhelyezése (Hedin, 2008), vagy éppen az épületek, alagutak, tározók és egyéb mesterséges szerkezetek mérnökgeológiai tervezése. A rendelkezésre álló információ ugyan soha nem elegendően részletes, a megismerhetőség valamilyen mértékben mindig korlátozott, mégis, kellően sokoldalú kutatással elég közel kerülhetünk a repedéshálózatok viselkedésének megértéséhez.

A világ művelés alá vont, vagy már letermelt kőolajmezőinek 35\%-át természetes módon repedezett karbonátos üledékes rezervoárként tartják számon, az összes ismert készletnek pedig közel fele található ilyen típusú tárolókban. Példaként álljanak itt az olajtermelésben élen járó Szaud Arábia, Kuvait, Irak és Irán olajtelepei, melyek jelenléte szinte egytől egyig kiterjedt töréshálózatokhoz kötődik. Az ugyancsak kőolaj-nagyhatalmak közé tartozó Egyesült Arab Emirátusok, Omán, Szudán, Szíria, Katar és Líbia területén található olajtárolókat pedig meghatározó részben szintén hasadozott kőzetek építik fel.

Hazánkban magmás-metamorf kőzetekbe migrált jelentősebb szénhidrogén előfordulásokat az Alföld néhány aljzati kiemelkedésében találunk. Ezek közül gazdaságilag is nagy szerepe volt a Szeghalom melletti Halom I és II mezők, valamint a Mezősas, Pusztaföldvár, illetve Battonya környéki telepek bányászatának a 70-es évektől kezdődően, ahol az alaphegység mállott, repedésekkel sűrűn átszőtt sekélyebb régiói alkotják a fő tárolót.

Az Alsó-Tisza-vidéki aljzati karbonátos, repedezett szénhidrogéntárolók közül a szegedi előfordulások (Szegedi dolomit), valamint az Üllés és Zsana környéki gáztárolók rendelkeznek 
figyelemre méltó termelési és kutatási múlttal. A hazai olajkutatás nagy jelentőségü aljzati szénhidrogén mezői Észak- és Dél-Zalában találhatók. Ezen a környéken a reménybeli olajtároló kőzeteket a tektonikailag zavart, vetőkkel különálló blokkokra szabdalt kréta mészkövek (pl. Ugodi mészkő) és triász korú dolomit (Fődolomit) alkotják, bonyolult mélyföldtani és teleptani adottságok (repedezett, karbonátos, lencsés kifejlődés) jelenlétében.

Hazánkban jelentős vízkészlettel - a preneogén képződményeket tekintve - a mezozóos karbonátos üledékes kőzetek, közülük is főként a triász időszaki mészkövek és dolomitok rendelkeznek. Míg számos régióban, többnyire a karsztos hegységek közvetlen előterében (Bükk, Dunántúli-középhegység, Budai-hegység) ezek a rezervoárok jelenthetik az ivóvíz-utánpótlás alapját, addig a mélyebb medencebelseji területeken a repedezett karbonátos vízadók alkotják a közepes és nagy entalpiájú hidrotermális rendszerek zömét.

Az ország területén található $14 \mathrm{db}$ hideg karszt víztest adja az éves ivóvíztermelés $10 \%$-át, ami összesen közel 73 millió $\mathrm{m}^{3}$-t jelent évente. Többek között Tatabánya, Veszprém, Várpalota, stb. városok ivóvízellátásának döntő hányada repedezett karsztrendszerekből történik. A termálkarsztok ezzel szemben föként a fürdők vízellátásában játszanak fontos szerepet, ez hozzávetőlegesen évi $15 \cdot 10^{6} \mathrm{~m}^{3}$ vízszükségletet jelent.

A repedezett karbonátos rezervoárok a bennük jelen lévő hidrotermális rendszerek révén igen jelentős, ám ezidáig kiaknázatlan potenciált jelentenek a geotermikus energia villamos erőmüvi felhasználását illetően is, mely úgynevezett bináris típusú ORC (Organic Rankin Cycle) technológia segítségével valósítható meg. A Pannon-medence jelentős részén, többek között a Zalaimedencében, Somogy-megye É-i részén, Budapest D-i előterében, a Bükk D-i előterében, valamint Csongrád és Békés megye É-i részén találunk olyan kiterjedt és összefüggő dolomit, illetve mészkő felépítésű vízadó rendszereket, melyek elegendő mélyre nyúlnak a 130-140 C-nál magasabb hőmérséklet eléréséhez.

A repedezett kőzettestek részletes vizsgálatára és feltérképezésére alkalmas módszerek nélkülözhetetlen szerepet kapnak a geotermikus iparág nagy entalpiájú, EGS (Enhanced Geothermal System) rendszereinek fejlesztésében is. Ez alatt olyan mesterségesen fejlesztett rezervoárt értünk, melynek létrehozásával gazdaságilag is hasznosítható mennyiségü hő vonható ki eredetileg alacsony permeabilitású és/vagy porozitású közegből (Tester és tsai., 2006). A kőzet által tartalmazott termál energia úgy nyerhető ki, ha a rezervoárban hidraulikus törésrendszert generálunk a nyomás mesterséges növelésével. A gyakorlati tapasztalatok azt mutatják, hogy a hidraulikus repesztés (hydrofracturing) ott lehet igazán eredményes, ahol a kőzettestet már eleve 
természetes repedésrendszer tagolja, s ennek alapvető geológiai jellemzői határozzák meg a hidraulikus stimulációval gerjesztett új hálózat karakterisztikáját.

Az így kialakuló mesterségesen létrehozott repedéshálózaton keresztuil szivárog át a besajtolt fluidum, felvéve a helyi geotermikus gradiensnek megfelelö, általában $150{ }^{\circ} \mathrm{C}$ feletti hőmérsékletet. E módszerrel tulajdonképpen a repedésfal, mint geológiai hőcserélő felület tud funkcionálni. Az elérhető termeltetési ráták, s így az adott projekt gazdaságosságának meghatározásában végül a repedéshálózat összefüggőségének és a generált törések nyitottságnak lesz döntő szerepe.

Az EGS-ben rejlő rendkívüli geotermikus potenciált hazánkban is célszerü lehet majd kiaknázni, tekintettel a fosszilis energiahordozókkal való ellátás kiszolgáltatottságára, a környezetszennyezésre és a növekvő energiaárakra. E szempontból a legígéretesebbnek a Délalföldi régió mutatkozik, ahol különösen a mély medencék közötti kiemelt helyzetủ kristályos alaphegységi hátak lehetnek a kutatás szempontjából optimális helyzetben (Dövényi és tsai, 2005).

Immár számos ország próbálkozik több-kevesebb sikerrel az EGS technika alkalmazásával, Soultz-souz-Forets-ben például már 2008 óta folyik áramtermelés a telepített 1.5 MW kapacitású ORC erőműben. A tárolókőzet paleozóos gránit, melyben 3 termelő és 2 visszasajtoló kút működik a 3000-5000 m mélységtartományban. A világ többi nagyobb EGS programja közül az Egyesült Államok-beli Desert Peak-nél egyelőre a projektfejlesztés fázisában tartanak, míg az ausztrálok elsőszámú projektje, mely a Cooper Basin 250-500 MWe-ra becsült elektromos potenciálját célozza meg, már a fúrási stádiumig jutott.

A mélységi geotermikus energia bányászat egyik fő problémáját napjainkban a lokálisan nagy mennyiségű fluidum besajtolása következtében észlelt repedés-terjedés és az ebből adódó szeizmikus aktivitás jelenti. A jelenség sok helyen a kitermelés ideiglenes csökkentésének (Landau, Németország) kényszerét, máshol az egész projekt leállítását (Bázel, Svájc) vonta maga után.

A repedezett tárolók fluidum-áramlási sajátosságainak tanulmányozása teljesen új megvilágításba kerül, amikor a hulladékelhelyezés problémájára kísérelünk meg hosszú távú megoldást találni. Ilyen esetekben - az előző két témakörrel ellentétben - a rezervoárnak pontosan azokat a tulajdonságait keressük és kényszerülünk bizonyítani aprólékos elemzésekkel, melyek a szivárgáshidraulikai viszonyokra negatív hatást gyakorolnak. A magmás-metamorf kőzetrendszerek bizonyos helyzetekben kedvező környezetet jelenthetnek a veszélyes anyagok tárolására, például ha a repedéshálózat kevésbé összefüggő jelleget ölt, $\mathrm{s}$ ezáltal egymással nem kommunikáló alrendszerek vannak jelen, vagy ha hidrodinamikailag elszigetelt kőzetblokkokat sikerül azonosítani. 
Az Egyesült Államokban a nevadai Yucca hegységben, a washingtoni Hanfordban, valamint az angliai Sellafield-ben (Chaplow, 1996) létesített felszín alatti nukleáris hulladéktárolók hosszú távú hidrogeológiai alkalmasságát döntően befolyásolja a kiterjedt repedésrendszer, valamint a nagyobb mérettartományokon megjelenő kiterjedt vetőegyüttesek viselkedése.

A kis és közepes aktivitású radioaktív hulladékok hazai tárolási helyének kiválasztásával kapcsolatban már a 90’-es évek elején elkezdődtek a vizsgálatok. A választás a Bátaapáti (Benedek és tsai, 2009) melletti karbon gránitra (Mórágyi Gránit Formáció) esett, ahová 12 év kutatómunka után végül 2008 végétől kerülnek elhelyezésre a paksi atomerőmű megfelelően előkezelt, hordókba zárt radioaktív elemei. A tárolótér valójában blokkos szerkezetü, a blokkokon belül összefüggő repedésrendszer alakult ki. Ezzel szemben az egyes térrészek közötti vízföldtani kapcsolatot finomszemcsés, általában agyaggal kitöltött tektonikai elemek akadályozzák. Érthető okokból a müszaki kivitelezés során törekedni kellett a blokkon belüli tároló kialakításra, valamint a blokkok közötti hidraulikai kommunikáció minimális szinten tartására.

Számos mérnöki projekt tervezése és megvalósítása kötődik szorosan olyan felszíni és sekély mélységü, kompakt kőzetek jelenlétéhez, ahol a repedezettség deformációt és permeabilitást befolyásoló hatása a legfontosabb tényezők közé sorolható. A kőzet terhelhetőségét ebböl a szempontból pozitívan befolyásolja a ritka repedéshálózat, a minél tömöttebb, jelentős struktúra nélküli felépítés. 


\section{I.2. Problémafelvetés és a kutatási célok definiálása}

Az Alföld alatti kiterjedt preneogén aljzat kőzettani felépítéséről terjedelmes információhalmaz áll rendelkezésre, melynek nagy része része az elmúlt 80 év több ezer szénhidrogén kutató fúrásából, az azokból származó magminták és geofizikai szelvények részletes leírásából származik. Ezen kívül a terület egy részét lefedő 2D és 3D szeizmikus felmérések, valamint egyéb geofizikai és magnetotellurikus felvételek feldolgozása ugyancsak hozzájárul a szerkezetföldtani és fejlődéstörténeti kép megalkotásához. A prevariszkuszi és variszkuszi korú metamorf képződményekből álló aljzatkomplexum helyenként mezozóos, főként karbonátos üledékes kőzetekkel fedett, míg másutt közvetlenül a neogén fedőképződmények települnek rá. Az üledékes környezet az előbb említett vizsgálati módszereknek köszönhetően földtanilag szintén viszonylag jól megkutatott.

Vízföldtani szempontból a mezozoikumnál fiatalabb üledékes kőzetek 2 nagy vízadót alkotnak. Az egyik a felső-pannóniai, alapvetően folyóvízi delta környezetben lerakódott, közepesdurva szemcsés homokkő és közbetelepülő agyagsávokból álló rezervoár. Ez az Alföld csaknem teljes területén meghaladja a $30{ }^{\circ} \mathrm{C}$-os izoterma mélységét, termálvizeink jelentős része is innen származik. A másik a fiatalabb pleisztocén törmelékes üledékek alkotta rezervoár, mely a fő felszín alatti ivóvízbázist jelenti, legnagyobb mélységét a makói árokban, Szeged környékén éri el (> $500 \mathrm{~m})$.

A két vízadó egy hidrodinamikai egységet alkot, ahol a központi kiemelt területeken (DunaTisza-közi hátság) beszivárgó víz a regionális áramlási rendszerhez kapcsolódva egészen a felsőpannóniai aljáig követhető (Tóth és Almási, 2001; Szanyi és Kovács, 2010), majd a mélyebb fekvésű peremeken (Duna, Tisza-mente, Körös-vidék) jut felszínre. A felső-pannóniai alatt közvetlenül települő alsó-pannóniai üledékek összetételében már a finomabb szemcsés aleurolit, agyag és márga játsszák a főszerepet, melyek rossz áteresztő képességük révén jelentősebb vízkitermelésre nem alkalmasak. Ez a néhol 2000 m vastagságot is meghaladó képződmény - a paleogén formációk esetleges jelenlététől eltekintve - választja el a sekélyebb gravitációs áramlási rendszert a mély, sok helyen túlnyomásos, repedezett kristályos és mezozóos karbonátos aljzati rezsim által tárolt fluidum rendszertől. Az aljzati komplexum nagy mélysége ellenére nem impermeábilis, másodlagos porozitása és tektonizáltsága révén különböző korú és összetételü fluidumok tárolódnak benne. Ezek vizsgálatának fontossága a szénhidrogén- és vízbányászat, valamint a geotermikus energia kutatás terén az I.1 fejezetben részletes bemutatásra kerültek.

Az említett két rendszer hidraulikailag nem teljesen elszigetelt, az aljzati magas oldottanyagtartalmú, idősebb vizek jelenlétét a pannóniai és pleisztocén üledékekben több helyen is kimutatták 
(Mádlné Szőnyi és tsai, 2005; Mádl-Szőnyi és Tóth, 2009; Simon és tsai, 2009; Varsányi és Ó. Kovács, 2009). Itt azonnal felmerül a kérdés, hogy vajon milyen módon töltődhetnek fel a repedezett aljzati tárolók, milyen irányokból, milyen szerkezetekből érkezhet a fluidum utánpótlása. A két alapvetően eltérő viselkedésű rendszer hidrodinamikai és hőterjedési folyamatainak komplex leírását leghatékonyabban numerikus modellezési vizsgálatok elvégzésével lehetséges megvalósítani. Mindezt kiegészítve a repedéshálózatokon végzett módszertani elemzésekkel, a következő feltevésekre és kérdésekre keresek magyarázatot:

1. A repedéshálózatok - fluidum-átjárhatóság szempontjából kritikus - összefüggőségi viszonyainak feltérképezése hogyan valósítható meg a legfontosabb geometriai paraméterek alapján; hogyan függ az összefüggőség az input paraméterektől?

2. Ezek a származtatott paraméterek egyértelmüen meghatározhatók-e, vagyis előrejelezhetö-e biztonsággal a törésrendszerek térbeli megjelenése, viselkedése a kőzetmintákon mérhető repedésparaméterek alapján?

3. Milyen minimális homogén elemi térfogat választható repedezett kőzetek esetén, mennyire változik ez a térfogat a törések térbeli sürüségének, hosszúságának és orientációjának függvényében?

4. Milyen módszer alkalmazható olyan esetben, amikor porózus és repedezett képződmények fluidum-áramlási tulajdonságait akarjuk vizsgálni egy rendszerben?

5. Az aljzatban tárolt fluidum milyen irányokból kaphat utánpótlást, milyen áramlási pályák lehetségesek?

6. Milyen hidraulikai kapcsolat van a repedezett aljzati tároló és az üledékes fedőképződmények között?

7. Hogyan befolyásolja az aljzati litológia és geometria az áramlást, változik-e a szivárgás az azonos összetételü kőzetblokkok helyzetének megváltozása következtében?

8. Hogyan módosul az áramlási kép a szerkezeti, tektonikai változatosság hatására?

9. Hogyan kapcsolódhatnak be az aljzati fluidumok a fiatalabb, felső-pannóniai - pleisztocén rétegek gravitációs áramlási rendszerébe?

10. Mennyire érzékeny a modell az egyes hidrodinamikai paraméterek, elsősorban a szivárgási tényező változására?

11. Milyen mértékü anomáliát okoznak az aljzati metamorf dómok a hőmérsékleti mezőben?

12. Milyen szerepe van a konvektív, illetve konduktív hőterjedésnek a hőmérsékleti viszonyok kialakulásában? 


\section{Repedéshálózatok vizsgálati lehetőségei}

\section{II.1. Repedések, repedéshálózatok szerkezetföldtani jellemzése}

A repedések által létrehozott kiterjedt hálózatok térbeli viselkedésének alaposabb megértéséhez, részletes elemzésük elvégzéséhez legelőször is az azokat létrehozó geológiai folyamatokkal kell tisztában lennünk. A fejlődéstörténet, szerkezet, s az ebből származó fizikai tulajdonságok ismerete pedig az adott repedezett térfogatra irányuló további kutatások, illetve hasznosítási törekvések miatt jut nagy szerephez.

\section{II.1.1 Törések kialakulása-tektonikai háttér}

A kőzet irányított feszültség hatására alapvetően háromféleképpen: rugalmasan, képlékenyen vagy törésesen viselkedhet. Ez utóbbi, a rideg kőzettestekre jellemző alakváltozás az előbbi kettőnél magasabb feszültségtartományban van jelen. A törés (fractus [lat], jelentése „törött”, „,öredezett”) mint fogalom definiálását többféle módon tehetjük meg, függően a vizsgálódás tárgyától. Míg egyes megközelítések leíró jellegűek, mások tisztán mechanikai szemléletet tükröznek (Ranalli és Gale, 1976). Egy általános definíció szerint a repedés olyan felületet jelent, mely mentén a kőzet kohéziója megszűnik, az anyagban folytonossági hiány lép fel (Twiss és Moores, 1992).

A töréses alakváltozás viszonylag közvetlen összefüggésben van a feszültségtérrel, a kőzet elsősorban ott fog elrepedni, ahol az anyag belső kohézióját legyőzik az abban ébredő tenziós- vagy nyírófeszültségek.

Húzás vagy egytengelyü összenyomás hatására a kőzetben általában nagyobb hasadék keletkezik, amely a legkisebb főfeszültség irányára merölegesen, a legnagyobb föfeszültséggel párhuzamosan helyezkedik el. Többtengelyü összenyomásnál rendszerint két vagy több, egymáshoz, illetve a legnagyobb főfeszültséghez szimmetrikusan hajló töréssík keletkezik, melyek mentén nyírásos jelleggel elmozdulnak a szomszédos tömbök.

A töréses deformációt befolyásoló legfontosabb külső és belső tényezők a következők:

- a kőzet anyagi minősége

- a stressz mértéke

- a stressz-komponensek irányai

- a környezeti nyomás

- a hőmérséklet

- a fluidum mennyisége

- a geológiai idő 
A törések mindig többedmagukkal együtt fordulnak elő, az egy feszültségtérben kialakult repedések pedig rendszert alkotnak, hálózatba rendeződnek. Ennek orientációját maga a feszültségtér, illetve az alakváltozási tér jellege szabja meg. A Mohr-rendszer jellemzően tiszta alakváltozáskor jelenik meg, míg a Riedel-rendszer nyírásos erők dominanciája esetén fejlődik ki. A feszültségtértől és a fluidumnyomástól függően mindkét esetben kialakulhatnak húzásos és nyomásos, valamint nyírásos eredetủ elemek.

\section{II.1.2 Törésfajták}

A természetben előforduló töréseknek számos fajtáját különböztethetjük meg. A tipizálást, függően a vizsgálódás céljától, különböző tulajdonságok és folyamatok alapján tehetjük meg. Az alábbiakban ezek közül a legfontosabbnak ítélt csoportok kerülnek bemutatásra.

\section{II.1.2.1 Tipizálás az elmozdulás iránya alapján}

A törések keletkezésekor létrejövő elmozdulások történhetnek egyrészt a felületre merőlegesen, vagy a felülettel valamilyen szöget bezárva; az így keletkező kőzettömbök vagy hasadékot alkotva szétválnak (dilatációs litoklázis), vagy összetolódnak úgynevezett nyomásoldódási felületet létrehozván (kompresszív litoklázis).

Az elmozdulás másrészt történhet a felület mentén, az így keletkező kőzettömbök a nyírási sík mentén csúsznak el egymás mellett. A nyírásos repedések esetében az elmozdulás iránya párhuzamos a törési síkkal. A felnyílás iránya általában valamilyen hegyesszöget $\left(\sim 30^{\circ}\right)$ zár be a maximális főfeszültség $\left(\sigma_{1}\right)$ irányával (Nelson, 2001).

A vetők esetében szintén egy felületről vagy keskeny zónáról beszélünk, ami mentén az egyik térrész párhuzamos felülettel vagy zónával mozdul el a másikhoz képest. A kifejezést általában a nyírásos repedések esetében, a méter nagyságrendü tartomány felett használjuk. Az egyes vetődéstípusok legkézenfekfőbb csoportosítása az in-situ feszültségtér főfeszültségeinek relatív nagysága és iránya alapján lehetséges (Anderson, 1951), ez határozza meg az elmozdulás jellegét (2.1 táblázat).

\begin{tabular}{llllll}
\hline \multirow{2}{*}{ Feszültségtér } & \multirow{2}{*}{ Vető jellege } & \multicolumn{3}{c}{ Föfeszülttség } \\
\cline { 3 - 5 } & & $\sigma_{1}$ & $\sigma_{2}$ & $\sigma_{3}$ \\
\hline eltolódásos & csapásirányú vető & $\mathrm{S}_{\mathrm{H} \max }$ & $\mathrm{S}_{\mathrm{v}}$ & $\mathrm{S}_{\mathrm{hmin}}$ \\
tenziós & normál vető & $\mathrm{S}_{\mathrm{v}}$ & $\mathrm{S}_{\mathrm{H} \max }$ & $\mathrm{S}_{\mathrm{hmin}}$ \\
kompressziós & inverz vető & $\mathrm{S}_{\mathrm{H} \max }$ & $\mathrm{S}_{\mathrm{hmin}}$ & $\mathrm{S}_{\mathrm{v}}$ \\
\hline
\end{tabular}

2.1 táblázat Az egyes vetőtípusok esetén ható főfeszültségek relatív nagysága és iránya. 
Oldalelmozdulásról akkor beszélünk, ha a két szomszédos kéregblokk egy nyírási sík mentén horizontálisan mozog. A csapásirányú vetők általában függőleges vagy ahhoz közeli helyzetüek. Ezekben az esetekben a legnagyobb főfeszültség vízszintesen hat, a legkisebb föfeszültség pedig ugyancsak vízszintes irányú: $S_{\mathrm{Hmax}}>S_{\mathrm{V}}>S_{\mathrm{hmin}}(\mathbf{2 . 1 / 1}$ ábra).

Normál vetővel, illetve normál vetős rezsimmel van dolgunk, amennyiben az adott kéregrészben tenziós feszültségtér uralkodik, így a kialakuló meredek dőlésű vető feletti kőzetrész lefelé mozdul el. Eredményeként összetett árok-sasbérc, illetve lépcsős szerkezetek jönnek létre.

Normál vető esetén a legnagyobb főfeszültség $\left(\sigma_{1}\right)$ azonos a vertikálisan ható feszültséggel $\left(S_{V}\right)$, a kőzet súlyából eredő nyomásnál pedig kisebbek lesznek a maximális és minimális vízszintes föfeszültségek, azaz $S_{\mathrm{V}}>S_{\mathrm{Hmax}}>S_{\mathrm{hmin}}(2.1 / 2$ ábra).

Feltolódás akkor történhet az adott kéregrészben, ha a vertikális főfeszültség kisebb a horizontális föfeszültségeknél: $S_{\mathrm{Hmax}}>S_{\mathrm{hmin}}>S_{\mathrm{V}}(\mathbf{2 . 1 / 3}$ ábra). Ilyenkor a mozgás ellentétes a vetősík dőlésirányával.

(1.)
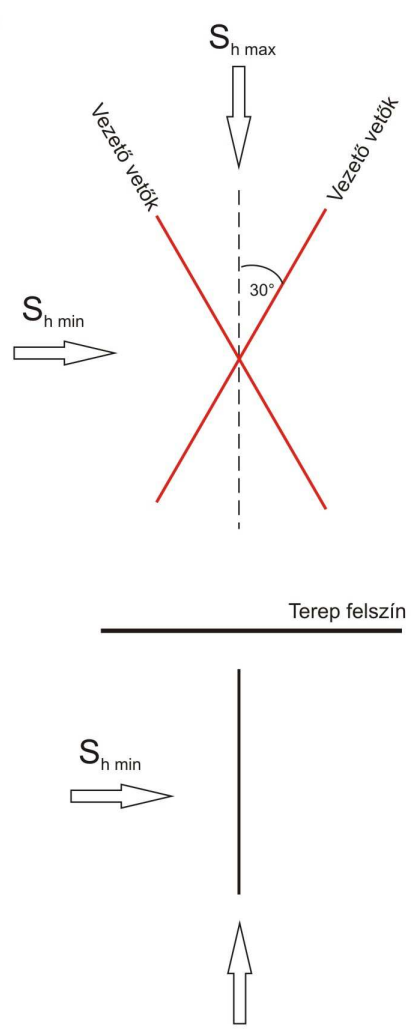

$\mathrm{S}_{\mathrm{v}}$
(2.)
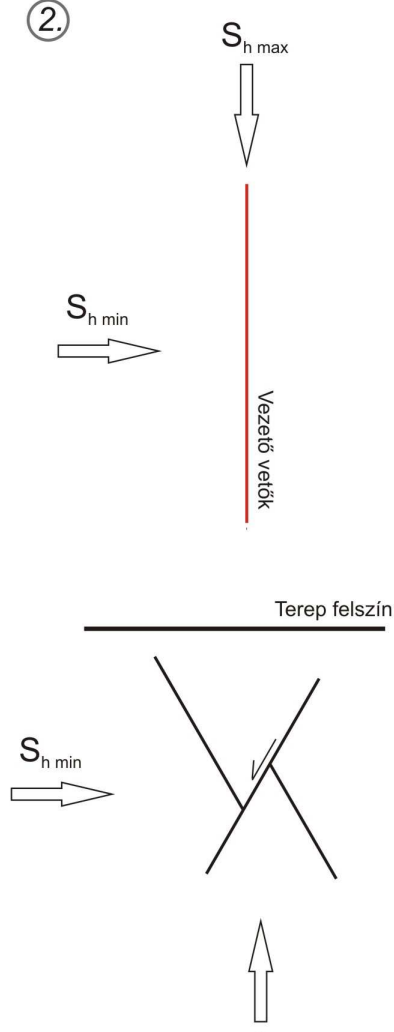

$\mathrm{S}_{\mathrm{v}}$

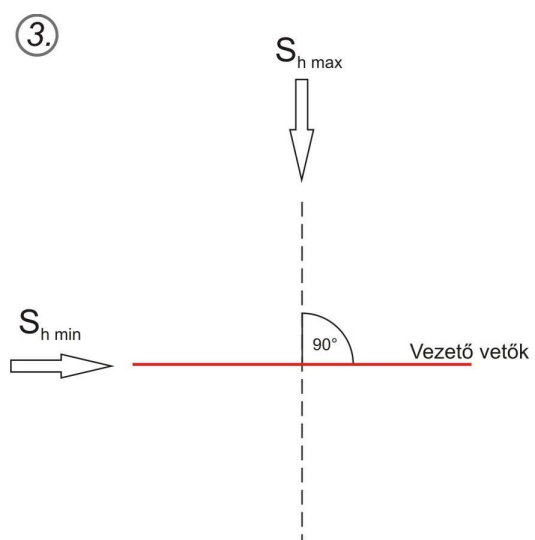

Terep felszín

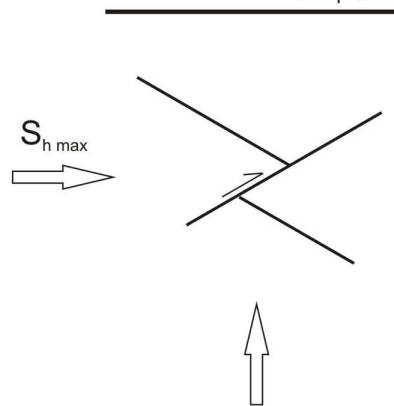

$\mathrm{S}_{\mathrm{v}}$

2.1 ábra A különböző típusú vetők és repedések orientációja a horizontális és vertikális főfeszültségek elhelyezkedése alapján, felülnézeti (felső sor) és oldalnézeti (alsó sor) sematikus illusztrációban. (1) közel vertikális oldalelmozdulásos vetők, melyek csapásiránya $\sim 30^{\circ}$-ot zár be a legkisebb horizontális föfeszültség $\left(\mathrm{S}_{\mathrm{H} \text { min }}\right)$ irányával. (2) a konjugált normál vetők $60^{\circ}$-hoz közeli dőlésűek, csapásuk $S_{\mathrm{H} \text { max}}$-al párhuzamos. (3) a feltolódási síkok dőlése $\sim 30^{\circ}$, csapásuk pedig merőleges a legnagyobb horizontális föfeszülttség $\left(\mathrm{S}_{\mathrm{H} \text { max }}\right)$ irányára. 


\section{II.1.2.2 Méret szerinti csoportositás}

A törések méretüket tekintve igen széles mérettartományt fognak át, a szabad szemmel még nem látható mikrorepedésektől kezdve egészen a több $10 \mathrm{~km}$, vagy akár több $100 \mathrm{~km}$-es vetőkig terjedőleg. A méret szerinti csoportosítások közül talán Babadagli (2001) négyes tagolású rendszere a legkifejezőbb:

- mikro-skála $(\mu \mathrm{m})$

- makro-skála (cm)

- mega-skála (m)

- giga-skála $(\mathrm{km})$

\section{II.1.2.3 Földtani szemléletü csoportositás}

A Nelson (2001) által ismertetett osztályozás a klasszikus Stearns és Friedman (1972) repedéscsoportosítási szemléletet bővíti ki két alapvető feltevés figyelembe vételével. Az egyik szerint a természetes repedésminták tökéletesen levetítik a kialakuláskori lokális feszültségtér állapotát, másodsorban pedig a mélységi kőzetrepedések és a laboratóriumi, valós körülményeket szimuláló tesztek alkalmával létrehozott törések viselkedésében analógia érvényesül. Ezek alapján Nelson a következő töréscsoportokat különbözteti meg:

\section{a) tektonikus törések}

A tektonikus repedések csoportját olyan elemek alkotják, melyek térbeli eloszlása, orientációja, morfológiája és egyéb attribútumai valamilyen lokális tektonikai esemény következményeként alakultak ki. A tapasztalat alapján a felszíni kibúvásokon észlelt elemek többsége nyírásos eredetü. Ezen repedések általában hálózatokba rendeződnek, melyek speciális kapcsolatban lehetnek a gyürődéses elemekkel és vetőkkel. További alcsoportokként a vetőkhöz kapcsolódó repedésrendszerek, a gyürődéses elemekhez kötődő repedésrendszerek és egyéb tektonikus törésrendszerek nevezhetők meg.

\section{b) regionális törések}

Ide tartoznak a földkéreg nagy területét átfogó, közel azonos orientáltságú, réteglapokra meröleges repedései. Kifejlődésük egy konzisztens és egyszerü geometriával jellemezhetö, rendszerint egymással derékszöget bezáró halmazokba rendeződnek, csapásirányuk enyhén változik formációról formációra. A regionális törések kialakulása minden jel szerint extenziós feszültségtérhez kötött, ahol a maximális főfeszültség iránya vertikális. 


\section{c) összehúzódásos repedések}

Ebbe a csoportba azok a tenziós repedések sorolandók, melyek kialakulása valamilyen fajlagos térfogatcsökkenéssel hozható kapcsolatba. A létrehozó folyamatok az alábbiak lehetnek:

- száradás

- szinerézis

- termikus gradiens

- ásványi fázisátalakulás

Mivel ezek a törések alapvetően az anyag belsejében koncentrálódó erők hatására keletkeznek, így eloszlásuk sem feltétlenül korlátozódik lokális geológiai szerkezetekhez. Az üledéklerakódás, majd diagenezis alatt kialakuló törések a szénhidrogén-csapdák elhelyezkedésétől függetlenül találhatók meg egyes rezervoárokban (pl. gáztermelés az USA középső államaiban (Nelson, 2001)). A szénhidrogéniparban betöltött fontos szerepük, még pontosabban a gázkutatás terén elért magas termelési értékük is ennek köszönhető.

d) felülethez kötődő repedések

Az ilyen fajta törések leggyakrabban az anyag által tárolt feszültség felszabadulásakor, szabad felszínek kialakulása hatására, vagy a mállás során jönnek létre a kőzetegyüttesekben. Szénhidrogén-tárolás szempontjából túl nagy jelentőséggel nem rendelkeznek.

\section{II.1.2.4 Kategorizálás a kitöltöttség alapján}

A repedésrendszeren átszivárgó fluidum kémiai tulajdonságainak megváltozása, vagy a kőzettest fizikai állapotában (hőmérséklet, nyomás) bekövetkező változások ásványi anyag kiválását eredményezhetik a törések falán. A repedés fajtájától függően megnevezett ásványerek, telérek és pull-apart szerkezetek megváltoztatják az áramlási sajátosságokat, mivel a rájuk jellemző permeabilitás különbözik a kőzetváz átlagos permeabilitásától. Ez a fajta negatív visszacsatolás főként a magmás és metamorf kőzetegyüttesek áteresztőképességét redukálja, míg a karbonátos kőzetek járataiban szivárgó fluidum sokkal inkább oldja a repedések falát, növelve ezzel az átjárhatóságot. A repedéskitöltő ásványok ezenkívül információt nyújthatnak a szivárgó fluidum természetéről, a törések nyitottságáról, valamint a kiválás során jelen lévő kémiai és fizikai folyamatokról.

Egy példát említve, Nelson (2001) a repedések morfológiája és kitöltöttsége alapján a következő osztályokat határozza meg: 
- nyitott repedések

- deformált törések

○ barázdált

○ vetőkarcos

- ásvánnyal kitöltött repedések

- üreges törések

\section{II.1.2.5 A repedések fluidum-áramlásban betöltött szerepe}

A töréseknek talán az egyik legfontosabb megkülönböztetése hidrodinamikai szerepük alapján történhet meg. Amennyiben a repedezett kőzettest rezervoár tulajdonságait elemezzük, akkor a töréshálózat hidraulikailag aktív elemeit kell mindenekelött feltérképezni. Az, hogy az adott repedés képes-e fluidum vezetésére, vagy hidraulikailag szigetelőként viselkedik, elsősorban a jelenlegi feszültségtérben elfoglalt helyzetétől függ. Előfordulhat, hogy az egykor kialakult nyitott repedésegyüttes a jelenlegi feszültségtér megváltozott irányultsága miatt záródott, s ezáltal nem, vagy csak korlátozott mértékben vesz részt a fluidum-szállításban.

A fluidum-áramlásban leginkább a nyírásos eredetű törések vehetnek részt, míg a hajszálrepedések szerepe ennél jóval kisebb a rájuk jellemző minimális nyitottság miatt. A vetők tekintetében elmondható, hogy a vető központi része, a magzóna a cementanyag-kitöltés mennyiségétől és minőségétől függően vezet vagy szigetel, a külső, jellemzően 10-100 m vastag repedezett zóna (kárzóna) azonban rendszerint a mellékkőzetnél nagyságrendekkel jobb vezetőképességgel rendelkezik (Evans és tsai, 1997).

\section{II.1.2.6 Egyéb szempontok szerinti megkülönböztetés}

Az elöbbiekben felsorolt, repedések megkülönböztetésére használatos szempontokon kívül megjegyzendő még az egymástól elváló felületek sík vagy térben elhajló (lisztrikus) jellegének megkülönböztető szerepe. A sík geometriájú, szisztematikus törések térben szabályos elrendeződést követnek, míg a nem szisztematikus repedések általában nem metszik egymást és valamilyen réteghatár mentén végződnek el. Amennyiben a kifejlettség mértékét vesszük a csoportosítás alapjául, akkor egyrészt beszélhetünk elsőrendü, több réteget átszelő repedésekről, vagy megkülönböztethetjük a csak egy rétegre kiterjedő másodrendü töréseket. 


\section{II.2. Matematikai jellegü megközelítés}

A repedéshálózat és az egyedi törések komplex geológiai jellemzésén túl a matematika eszközeivel történő részletes leírásra és vizsgálatra szintén nagy hangsúly kerül. Mindez egyrészt a valóságot minél jobban közelítő modellbe integrálás, továbbá a térbeli eloszlásra vonatkozó statisztikai törvényszerűségek kidolgozása céljából szükséges. A geometrián belül a fraktál geometria nyújt segítséget ahhoz, hogy a törések mintázatának ismétlődését vizsgálni tudjuk a különböző mérettartományok között (Barton, 1995).

\section{II.2.1 Az egyedi törések parametrizálása}

Egy repedezett kőzettestet alapvetően 3 fő komponens, a repedéshálózat, a kőzetmátrix, valamint - amennyiben jelen van - az érkitöltő anyag épít fel. A hálózat minden egyes diszkontinuitási eleme egyértelműen leírható olyan tulajdonságok halmazával, melyek valamilyen módon matematikailag is kifejezhetők, számszerűsíthetők. Ily módon kapjuk a repedéshálózat numerikus modellbeli ábrázolásához szükséges input paraméterek sokaságát. Az egyedi törések egyes jellemzőit a 2.2 táblázat tartalmazza.

\begin{tabular}{ll}
\hline Paraméter & Leírás \\
\hline Töréscsoportok száma & A repedéshálózatot alkotó diszkontinuitás-halmazok száma \\
Orientáció & A megjelenő törés térbeli helyzete, dőlés-csapás adatpárral \\
& kifejezve \\
Töréstávolság & A szomszédos diszkontinuitási síkok közötti merőleges \\
Állandóság & távolság \\
& Törés felszíni kibúváson észlelt nyomvonalának hossza \\
Sürüség (1-3D) & Egységnyi hosszra jutó törésszám (1D); egységnyi területre \\
& eső kumulatív töréshossz (2D); egységnyi kőzettérfogatra jutó \\
Repedésterület és forma & kumulatív törésfelület (3D) \\
Térfogati repedésszám & A repedezett felület területe és formája \\
Mátrix blokk egység & Egy köbméter kőzettérfogatba eső repedések darabszáma \\
Összefüggőség & A repedéshálózat által tagolt kőzetblokkok mérete és formája \\
Nyitottság & A törések metsződésének és elvégződésének jellege \\
A szomszédos repedésfalak közötti merőleges távolság nyitott \\
Érdesség
\end{tabular}

2.2 táblázat A töréses elemek jellemző tulajdonságait kifejező paraméter lista (Singhal és Gupta, 1999). 


\section{II.2.1.1 Repedéshosszúság}

A valós 3D térben megjelenő repedés méretét a hosszúság és a nyitottság jellemzi. A töréses elemek egyik legfontosabb, fluidum-áramlás és összefüggőség szempontjából alapvető tulajdonsága a repedések hossza. Ez valójában a diszkontinuitási felület kiterjedtségének mértékeként értelmezhető, ami a természetben egy nem síkbeli távolságként jelentkezik. A használt repedéshálózat modelltől függően különböző közelítéseket alkalmazunk, így például a valódi hossz a „parallel plate” modellben (Huitt, 1955; Snow, 1965) a repedéseket reprezentáló hengerek körlapjainak átméröjével jellemezhetö.

A törések hosszúságát meglehetősen nehéz számszerüsíteni, ugyanis az egyedi törések különböző térbeli orientációja miatt, azaz más és más dőlés/csapás értékek mellett különböző mértékben torzul a valós hossz is.

\section{II.2.1.2 Orientáció - dölés/csapás}

A repedések - akárcsak bármely más, síklappal közelíthető geológiai elem - térbeli irányultsága két paraméter, a dőlésirány és dőlésszög, azaz egy $\mathrm{x}^{\circ} \mathrm{y}^{\circ}$ alakú értékpár segítségével egyértelmủen meghatározható. A repedések orientációja jelentősen befolyásolja a permeabilitás anizotrópiájának kialakulását, valamint - ahogyan azt később látni fogjuk - nem csekély szerepe van a töréshálózat összefüggőségének szabályozásában is. Akár terepi mérésekről van szó, akár közvetett úton szerzünk információt az egyedi repedések orientációjáról, a mérés és értelmezés mindig valamilyen mértékű pontatlansággal terhelt, aminek kiküszöbölésére célszerü az adott repedéscsoportot statisztikai analízis alá vetni.

\section{II.2.1.3 Érdesség}

A repedés érdessége, mely alatt a törésfalon kialakult egyenetlenség (kisebb mérettartományon értelmezett szabálytalanság) illetve hullámosság (nagyobb mérettartományon értelmezett unduláció) mértékét értjük, szintén a fontosabb repedés-paraméterek közé tartozik. Az érdesség alapvetően kihatással van az adott törés síkjában fellépő nyírófeszültség nagyságára (Patton, 1966), míg jelentősége rohamosan csökken a nyitottság növekedésével, vagy a repedéskitöltő ásványfázis térhódításával. A repedésfal érdessége okozza - egy sokkal komplexebb környezet megteremtésével - az egyes töréseken belül az áramlási csatornák kialakulását, komolyan befolyásolva ezzel a kőzettest szivárgási paramétereit (Lespinasse, 2000). A tulajdonság kvantitatív meghatározására leggyakrabban a JRC (Joint Roughness Coefficient) módszer használatos (Barton, 
1973), de a fontosabb mérési módszerek közé tartozik a fraktál dimenzió, spektrálanalízis, vagy a statisztikai mutatók használata is (Jing és Stephansson, 1995).

\section{II.2.2 A repedés-paraméterek térbeli eloszlása}

Az adott törésgenerációkhoz tartozó törések, azaz egy meghatározott feszültségtérben nyíló repedéscsoport elemei nem teljesen véletlenszerủen töltik ki a teret, hanem az általuk mutatott mintázaton mindig valamilyen matematikai törvényszerüség fedezhető fel. Ez a tulajdonság a matematikai fraktálok segítségével írható le, mondhatni a természetben kialakuló komplex formák részletes vizsgálatához a fraktál geometria eszközeit a legcélszerűbb alkalmazni. Mandelbrotnak (1983) a fraktálokról alkotott elmélete ma már igen széles körben alkalmazott a földtudományokban. Ugyanez a tudományterület eszközt ad arra, hogy topológiailag korlátozott mintákból következtethessünk a repedések, repedéshálózat egészének tulajdonságaira (Barton, 1995).

A természetben előforduló törések valójában fraktálszerü elrendeződést mutatnak. Ezeket a struktúrákat egyben az önhasonlóság is jellemzi, ami azt jelenti, hogy bármilyen kisebb részletet kiragadva a teljes képpel közel azonos mintázatot fedezhetünk fel. E másolatok azután a megfelelő hasonlósági transzformáció alkalmazásával visszaadják az eredeti mintázatot. Így a természetben előforduló repedéshálózat-mintázatok is bizonyos fokú - de nem a szigorú értelemben vett matematikai - hasonlóságot mutatnak különböző mérettartományokon vizsgálva.

Az említett fogalmakkal kapcsolatban tisztázni kell, hogy amennyiben egy térbeli struktúra önhasonló, az még nem jelenti azt, hogy fraktál természetü is. A négyzet például kisebb négyzetekre osztható, vagy egy kocka feldarabolható további kis kockákra hasonlósági transzformációval, mégsem beszélhetünk fraktálokról.

A kőzetekben elöforduló természetes eredetü törések és törésrendszerek parametrizálása a következőkben szigorúan e fraktálszerü jelleg és önhasonlóság figyelembe vételével történik.

\section{II.2.2.1 Töréssürüség}

Adott kőzettérfogatot kitöltő repedések térbeli sürüségének meghatározására többféle lehetőség van. Használhatunk például db/m mértékegységet, ami tetszőleges helyzetű egyenes által elmetszett repedések metszéspontjainak egy méterre eső darabszámát adja meg, vagy analóg módon, a dimenziók kiterjesztésével a $\mathrm{db} / \mathrm{m}^{2}$, illetve $\mathrm{db} / \mathrm{m}^{3}$ egységek is alkalmazhatók. Egy másik megközelítésben meghatározhatjuk a repedéshálózat tetszőleges síkmetszetének egy $\mathrm{m}^{2}$-es felületére jutó töréshosszt $\left(\mathrm{m} / \mathrm{m}^{2}\right)$, vagy három dimenzióban kifejezhető az egy köbméter térfogatra eső törésfelület $\left(\mathrm{m}^{2} / \mathrm{m}^{3}\right)$. 
A fraktál dimenzió $\left(D_{f}\right)$ is egy olyan tulajdonsága a vizsgált repedéscsoportnak, mely a térbeli sürüségröl ad kvantitatív információt. A matematikusok által definiált néhány tucat dimenziótípusból talán az alábbi három (Mandelbrot, 1985) a legelterjedtebb a gyakorlatban:

a) „box counting” dimenzió

b) ,self-similarity” dimenzió

c) „compass” (vagy „divider”) dimenzió

A fraktál dimenzió Mandelbrot féle első verziója, a „box-counting” dimenzió (Mandelbrot, 1985) alkalmazásaival találkozhatunk legtöbbször a földtudományokban. Ez a megközelítés egy olyan szisztematikus méréssorozatot jelent, amely bármilyen síkbeli mintára alkalmazható, továbbá könnyen kiterjeszthető térbeli struktúrákra is. Meghatározásához azt az elvet követjük, hogy az adott struktúrára - esetünkben a repedésháló mintázatára - meghatározott cellaméretű ( $s$ ) grid rácsot fektetünk, és megszámoljuk azon cellákat $(N)$, melyek a struktúra valamely részét tartalmazzák (2.2 ábra).

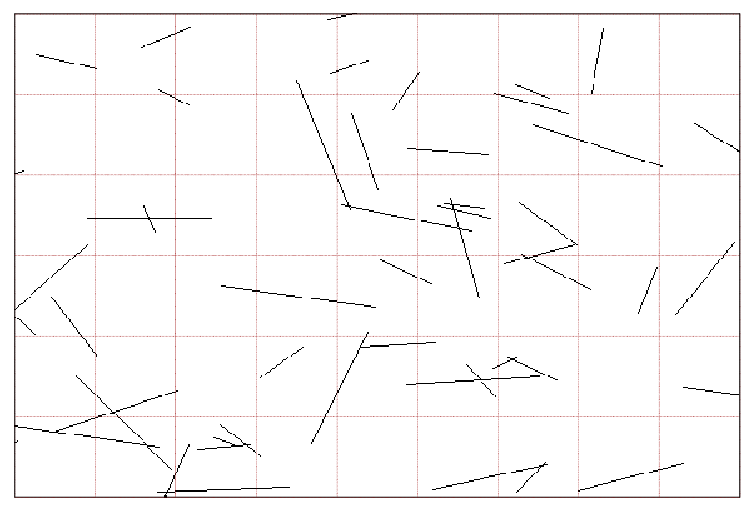

$\mathrm{s}=1 / 9 \quad \mathrm{~N}(\mathrm{~s})=49$

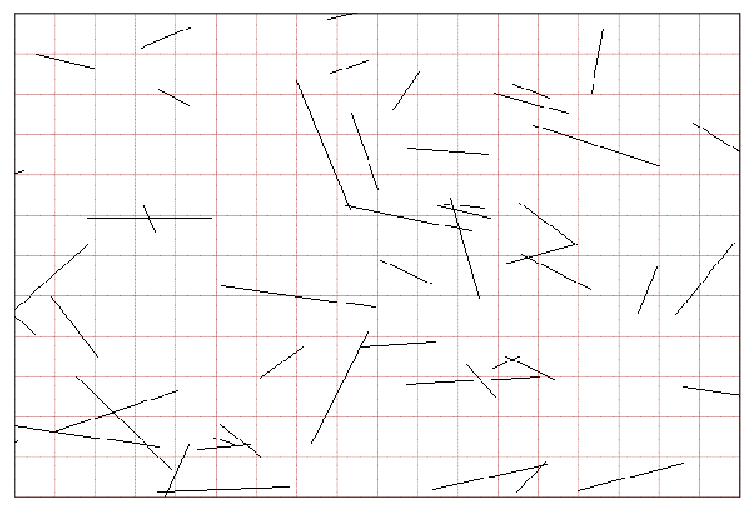

$\mathrm{s}=1 / 18 \quad \mathrm{~N}(\mathrm{~s})=114$

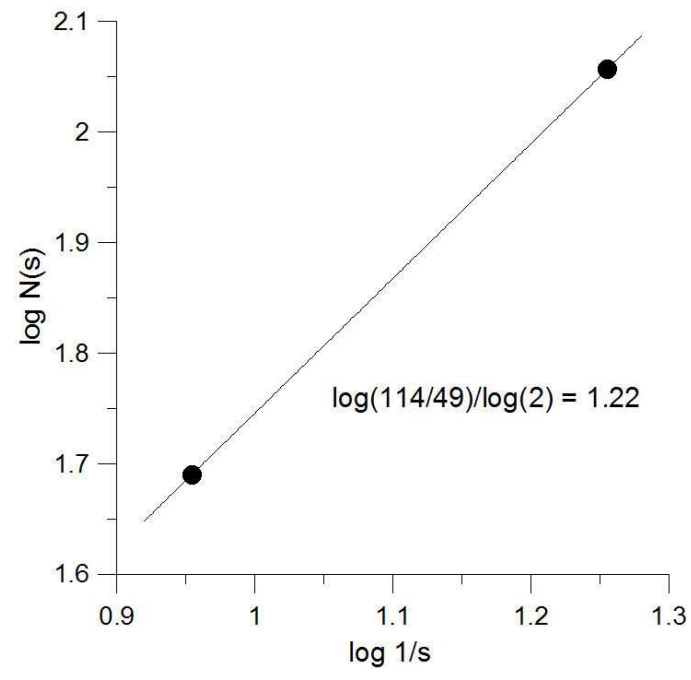

2.2 ábra A „,box-counting” módszer elve két különböző felbontású rácsháló esetén $\left(D_{f}=1.22\right)$. 
Könnyen belátható, hogy $N$ a cellamérettől függő változó, jelölésére használhatjuk az $N(s)$ kifejezést. A következőkben $s$ méretét arányosan csökkentjük, miközben $N(s)$-t minden felbontásnál feljegyezzük. A matematikai fraktálok esetében a két változó értékei között hatványfüggvény típusú összefüggés van, így a log-log transzformáció elvégzése után lineáris kapcsolatról beszélhetünk. A „box-counting” dimenziót a pontokra illesztett egyenes meredeksége $\left(D_{f}\right)$ adja, vagyis

$$
D_{f}=\frac{\log N(s \cdot k)-\log N(s)}{\log (s \cdot k)-\log (s)}
$$

ahol $k(\in Z) \geq 0$. Meg kell jegyezni, hogy a természetben előforduló repedésrendszerek fraktálszerü természete miatt a log-log diagram pontjai nem fognak pontosan egy egyenesre esni, az illesztés mindig valamilyen hibával terhelt.

Példaként az egyenes „,box-counting” dimenziója 1, a síké 2, a vizsgált térfogatot kitöltő kockáé pedig 3. Ennek megfelelően egy repedéshálózatból előállított 2D-s metszet dimenziója 1 és 2 között, a 3D térben leképezett törésmintázatok pedig 2 és 3 közötti értékekkel jellemezhetőek.

A fraktál dimenzió az önhasonlóság miatt a szomszédos mérettartományok között közel azonos, a tapasztalat szerint azonban széles skálán (mm-től a km-es nagyságrendig) kismértékü növekedés figyelhető meg (Babadagli, 2001; Tsuchiya és Nakatsuka, 1995; Tsuchiya és Nakatsuka, 1999) a vizsgálati mérettartomány növelésével.

A „box-counting” dimenzió nemcsak az adott repedéscsoportot reprezentáló térbeli vagy síkbeli elemekre, hanem a repedések középpontjaira is meghatározható, bár a két esetben egymástól eltérő eredményt kapunk. Ugyanazon minta esetében a törésközéppontok fraktál dimenziója $(D)$ elmarad a repedéshálózat nyomvonalán számított dimenziótól (Babadagli, 2001). A kutatás során gyakorlati okokból az előbbi módszert használtam.

\section{II.2.2.2 Dölés/csapás}

Míg az egyéni repedésekhez egy dőlés/csapás értékpár tartozik, addig egy repedéshalmaz orientációját ezen értékpárokból képzett matematikai eloszlással közelíthetjük. Az eloszlásfüggvény valójában csak adott törésgenerációhoz tartozó repedések esetén nyújt használható információt, ugyanis különböző időben és feszültségtérben kialakult törések esetén természetszerüleg teljesen eltérő térbeli orientáció tapasztalható. A jellemző eloszlás legjobban a kétváltozós Fisher függvénnyel közelíthető (Fisher, 1953).

Egy adott repedéscsoport regisztrált dőlés/csapás értékpárjainak halmazán elvégezhető statisztikai analízishez és megjelenítéshez többféle módszer áll rendelkezésre. A legelterjedtebb módszer a sztereografikus projekció, mellyel geológiai eredetü, síkszerü felületek térbeli 
orientációja és a dőlés-csapás adatpárok térbeli eloszlása jeleníthető meg. A megjelenítés gyakran a póluspontok sűrüségeloszlásának klaszterezésével (2.3 ábra) történik, így adott repedéshálózat esetén a csapásirányok relatív koncentrációja könnyebben vizsgálható. Egy másik igen elterjedt módszer a rózsa diagram, ami különféle irányított trendek relatív statisztikai gyakoriságát hivatott ábrázolni, mint például a törések csapásiránya (2.3 ábra). A dőlésértékek nagyságának ábrázolását ez utóbbi módszer nem foglalja magába.

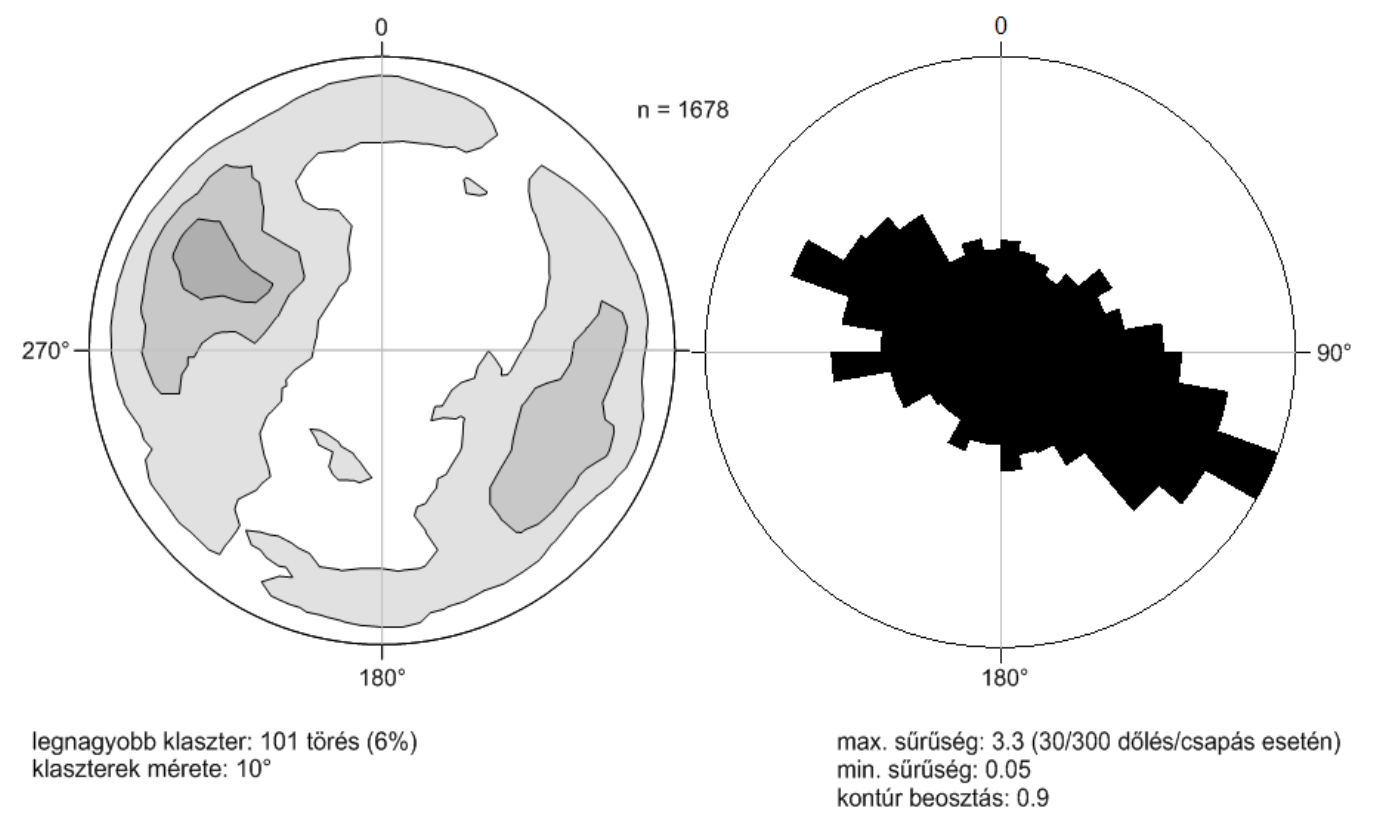

2.3 ábra Az Üveghuta-30 fúrás gránitjának 0-300m-es mélységtartományában észlelt repedések (1678 db) dőlés/csapás értékei.

\section{II.2.2.3 Hosszúság/nyitottság-eloszlás}

Az egyedi repedések hosszúságának és nyitottságának értelmezése után a repedéshálózat egészére is kiterjesztjük a két változó szempontjából történő jellemzést, mely matematikai eloszlásfüggvények segítségével válik lehetővé. A hosszúság kifejezése esetében azt az általánosan elfogadott feltevést alkalmazzuk, mely szerint egy adott törésgenerációhoz tartozó rövid elemek száma jóval meghaladja a hosszabb egyedek számát. A nagy és kis törések relatív mennyisége, egymáshoz viszonyított aránya a skálainvariancia miatt nem változik a méretarány változtatásával. Ebből következően, az összefüggés szerint a - természetes úton kialakuló törés-populációkban - a repedések száma és hossza közötti matematikai kapcsolat hatványfüggvénnyel írható le, s ez a kapcsolat a szerkezetfejlődés és progresszív deformáció során tapasztalt repedésterjedés hatására sem változik meg (Cladouhos és Marrett, 1996). Logaritmikus skálán a két változó között közel lineáris kapcsolat áll fenn (2.4 ábra). 


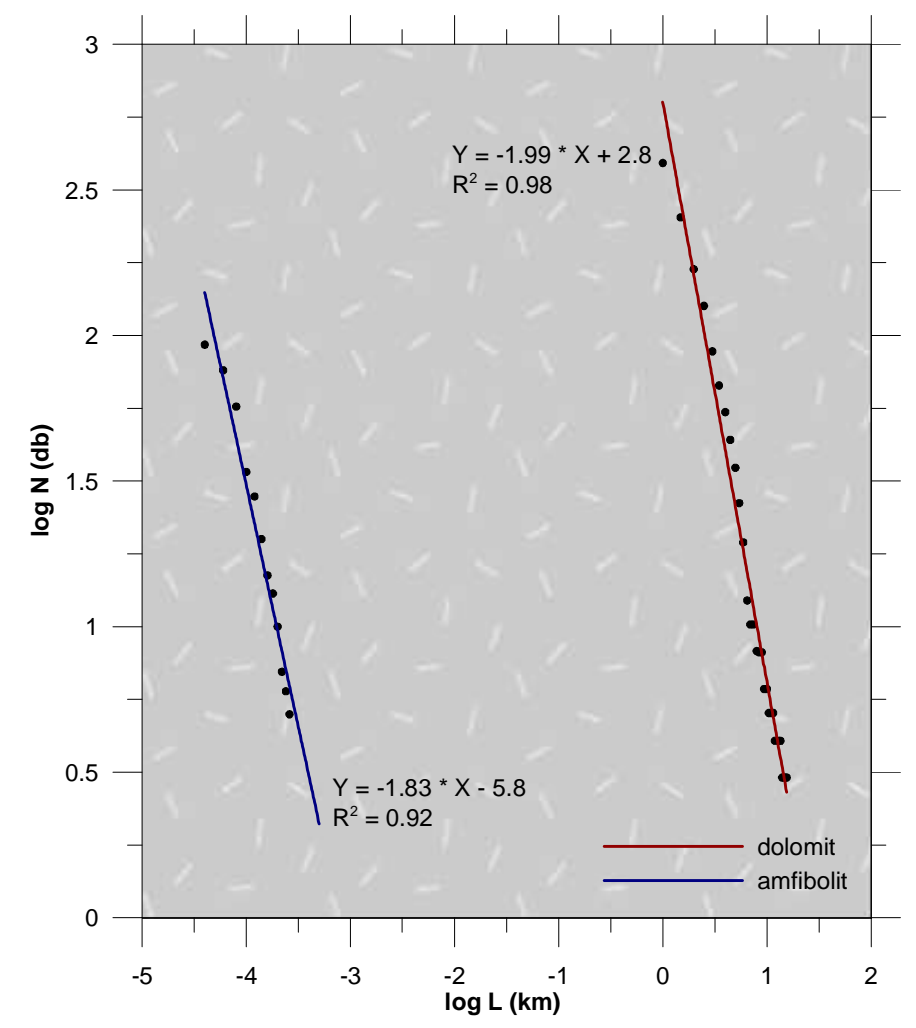

2.4 ábra Egyedi repedések hosszúságeloszlása dolomitban (Középső-Atlasz plató, Rouai (2006) nyomán) és amfibolitban (Szeghalom-2. sz. fúrás, M. Tóth és tsai, 2004 alapján).

Így, a leggyakrabban használt modell alapján (Yielding és tsai, 1992; Min és tsai, 2004; Segall és Pollard, 1983; Barton és Larsen, 1985; Scholz és Cowie, 1990) adott repedéshálózat hosszúságeloszlását a

$$
N(>L)=F \cdot L^{E}
$$

egyenlet írja le, ahol $N$ jelenti az $L$-nél hosszabb repedések számát, $F$ a minta méretétől függő konstans, $E$ a töréshosszúság hatványkitevője. A két oldal logaritmusát használva pedig a

$$
\log (N)=E \log (L)+b_{1}
$$

egyenlettel adhatjuk meg a lineáris kapcsolatot. Az $E$ hatványkitevő minden esetben negatív előjelü, értéke általában -1 és -2 értékek között változik (Rouai, 2006).

A hosszúság pozitív korrelációban van a nyitottsággal (A) (Cartwright és tsai, 1995; Clark és Cox, 1996; Cowie és Scholz, 1992; Johnston és McCaffrey, 1996; Olson, 1993; Peacock, 1991; Vermilye and Scholz, 1995; Walsh és Waterson, 1988), a közöttük lévő összefüggés legtöbbször jól kimutathatóan lineáris jellegü (Vermilye és Scholz, 1995). Más szóval a kapcsolat a következő kifejezéssel közelíthető: 


$$
A=a \cdot L+b_{2} .
$$

Az a paraméter értéke a statisztikai mérések alapján $2.1 \quad 10^{-4}$ és $8.210^{-3}$ között változik, 0.24-es igen gyenge és 0.96-os erős korrelációs koefficiens mellett (Vermilye és Scholz, 1995). Az egyenes meredekségében enyhén növekvő tendencia figyelhető meg a litológia változásával, magmás kőzetekre kisebb, törmelékes üledékes kőzetekre közepes, karbonátos kőzetekre pedig nagyobb értékek jellemzőek. Ez a megfigyelés az említett kőzettípusok növekvő duktilitásának köszönhető (Bürgmann és tsai, 1994), ami pedig konzisztens a nyomásoldódási aktivitás fokozódásával. A $b_{2}$ értéke a valóságban természetszerüleg minden esetben nulla kell legyen, ezzel szemben, mivel az együtthatókat általában lineáris regressziós analízissel határozzuk meg, nullától különböző értékek is előfordulnak.

Meg kell jegyezni, hogy a matematikai kapcsolatot néhány szerző logaritmikus, vagy hatványeloszlással közelíti (Johnston és McCaffrey, 1996), míg például Jamison (1997) egyáltalán nem talál kimutatható kapcsolatot a két paraméter között. Ezt a szakmai egyet nem értést alapvetően a nyitottság mérése során fellépő nehézségek és bizonytalanságok okozzák.

\section{II.2.3 Törésparaméterek mérési lehetöségei}

Az előző fejezetekben részletesebben is tárgyalt repedésparaméterekről a földtani helyzet és megkutatottság függvényében korlátozott mértékben, és minden esetben csak meghatározott részletességgel szerezhetünk kvantitatív információt. Természetesen a mérhető adatmennyiség drasztikusan lecsökken, amennyiben a vizsgálni kívánt repedezett térfogat nem jelenik meg felszíni kibúvásban vagy feltárásban, illetve mélységi helyzetében fúrás nem harántolja, s ezáltal közvetlen fizikai mintapéldány sem áll rendelkezésre. Az információ részletessége pedig, vagyis az a mérettartomány, skála, amin az adott tulajdonságok „láthatóvá” válnak, egyértelműen az adott esetben alkalmazható vizsgálati módszer vagy módszerek felbontásától függ.

Mindemellett további korlátozó tényező lehet a mérés pontatlansága, a mérési dimenziók közötti konverzió okozta adatvesztés, valamint a számítási algoritmusok bizonytalansága.

A következőkben felsorolt repedésparaméter mérési technikák alkalmazása ugyan nem képezi tárgyát e munkának, a vizsgálati módszer egészének megértése miatt azonban, a teljesség igényét szem előtt tartva mégis célszerünek éreztem mindezt bemutatni.

\section{II.2.3.1 Magminták elemzése}

A magmintavétel a magfúróval harántolt kőzet eredeti szerkezeti állapotát megközelítő kőzetmintát eredményez. Az így kinyert kőzetanyag vizsgálatával kapjuk a legközvetlenebb 
információt a repedésrendszerről, ami a legpontosabb repedésazonosítást és jellemzést teszi lehetővé.

A mag szeletelésével, ami ugyan kissé időigényes folyamat, a szerkezeti paraméterek közvetlenül mérhetők és tanulmányozhatók. Itt a néhány mm-től a néhány $10 \mathrm{~cm}$-es méretig terjedő tartományban van lehetőség mérni.

A magszkenner ezzel szemben a kőzetmag hengerpalástjának nagy felbontású képét készíti el a vizsgálni kívánt magszakaszon. Ezt az eljárást a mag minőségi roncsolásmentes vizsgálatára fejlesztették ki, mely lehetővé teszi a kőzet fizikai és geokémiai jellemzését. Alkalmas szoftver kapcsolt használatával a szerkezeti elemek könnyen osztályozhatók, a törések dőlés-csapás adatai automatizált módon származtathatók, illetve mindez szinkronba hozható az lyukszelvények adataival.

A mikroszöveti és szerkezeti jegyek meghatározására a kőzetvizsgálati módszerek közül a polarizációs mikroszkóp használata ad lehetőséget, az ásványos összetétel, szövet és szerkezet a kisebb, tized mm-cm mérettartományban vizsgálható. Vékonycsiszolat készítésével és mikroszkópos megfigyeléssel akár a mikronos nagyságrendü törések is számszerüsíthetők.

\section{II.2.3.2 Lyukfal leképezés módszerei}

A különféle lyukfal felvételező készülékekkel a fúrólyuk szükebb környezetében lévő repedéscsoport térbeli helyzetéről és eloszlásáról közvetlen információ nyerhető, emellett pontosabb képet kaphatunk a geológiai felépítésről, tektonizáltságról és az in-situ feszültségtérről. A lyukfal leképező módszereknek három fő típusa különböztethető meg a készülékek működési elve alapján (Prensky, 1999). Míg az akusztikus és elektromos készülékek közvetett módon szereznek információt a repedésrendszerről, addig az optikai technológiával közvetlen módon kerülünk kapcsolatba a lyukfal szerkezetével. Hatékonyságuk és elterjedtségük miatt itt csak előbbi kettő kerül bemutatásra.

\section{Akusztikus képkészítö készüilékek}

A lyukfal televíziók akusztikus hullámokkal pásztázzák körbe a vizsgált lyukfal teljes palástját egy folyamatosan forgó adó-vevő egység segítségével. Az eltelt idő alapján történik a beérkező hullámamplitúdó és terjedési idő adatok regisztrálása, majd a következő lépés az ezekből származó kép létrejöttéhez szükséges mủveletek elvégzése. Az amplitúdóképen a kőzet anyagi minőségében bekövetkező változások követhetők nyomon, míg a terjedési időkép változásaira jellemzően a fúrólyuk geometriája van hatással (2.5 ábra). 
A lyukfalkép elemzése alapján bejelölhetők a geológiai struktúrák (réteghatárok, repedések, üregek, kavernák) és mivel a CBIL (Circumferential Borehole Imaging Log) mérés orientált, ezért helyzetük pontosan leírható. A réteglapok, repedési síkok irányultságuk mellett dőlésük mértékével jellemezhetők, melyek meghatározása a lyukfalkép kiterített ábrázolásával, a hengerpalástot átmetsző síkbeli szerkezeti elemek szinusz-görbére illesztésével tehető meg legegyszerübben.

A dőlések és azimutok gyakoriságának vizsgálatával felderíthetők a fúrólyuk által harántolt rétegszakasz regionális és szerkezeti dőlésviszonyai, tektonizáltságának mértéke, feszültségterének, repedésrendszerének orientáltsága, illetve jobban átláthatóvá válnak az adott terület geológiai történetének részletei.

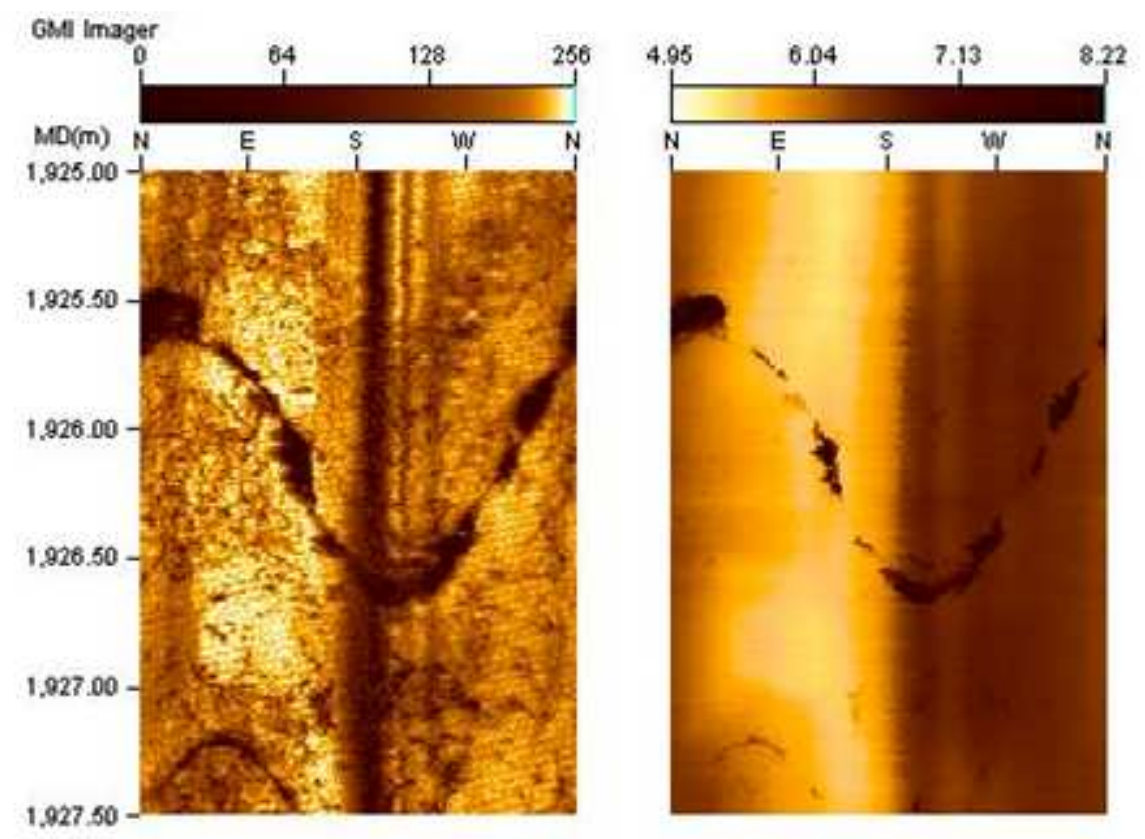

2.5 ábra A Soultz-sous-Forets-i GPK3 geotermikus kút ultraszonikus lyukfalképének részlete (bal oldal: amplitúdó kép, jobb oldal: idő kép) variszkuszi gránitban (Dezayes és tsai, 2005).

Mindemellett a lyukfalképen egymástól megkülönböztethetők lesznek a nyitott, félig zárt és valamilyen ásványi anyaggal kitöltött repedések (előbbiek az amplitúdó és az időképen egyaránt megjelennek), valamint számszerü információ vételezhető a repedéssürüségről. Mindkét esetben egy trigonometrikus transzformációt, a Terzaghi korrekciót szükséges elvégezni, mivel a lyukfal általános esetben nem merőleges a repedések síkjára, s ezért a valódi repedéssürüség nem teljesen egyezik a lyukfal mentén észlelt törésmetszetek közötti távolságok eloszlásával, valamint a valódi nyitottság sem azonos a lyukfalon észlelt nyitottság értékkel. A Terzaghi (1965) korrekció alapján minden egyes eredeti törés adatrekordhoz $N$ db feljegyzést rendelünk a következő formában:

$$
N=\min [(R / \cos \Theta), U]
$$


ahol $R$ egy egységes, véletlenszerü eltérés 0 és 1 között, $\Theta$ a repedési sík és a felvételezési irány közötti szögeltérés, $U$ pedig egy elöre definiált maximális korrekciós érték.

Habár nem minden korláttól mentesek, de léteznek megoldások a repedéshossz (Özkaya, 2003) és nyitottság számítására is a lyukfaltelevíziós képek alapján, ez pedig mintegy utat nyit az olyan hosszúságtól függő, a rezervoár jellemzéséhez nélkülözhetetlen paraméterek meghatározása előtt, mint a repedéssűrűség, összefüggőség és permeabilitás.

\section{Elektromos képkészitö rendszerek}

Egy másik, a szénhidrogéniparban igen elterjedt lyukfal leképezési technika az elektromos képkészítési eljárás, ahol is a fúrólyukba leeresztett elektród típusú eszközzel egy vezető munkaközegben ellenállást mérünk. A mért ellenállást az ásványtani folyamatok nagyban befolyásolják, alapvetően a porozitás, pórusfolyadék, pórusgeometria és cementáció mértéke határozza meg.

A fúrás során a nyitott repedésekbe bejutó iszap fajlagos ellenállása kisebb, mint a tömör kőzeté, valamint a repedéskitöltő ásványok is eltérő vezetőképességgel rendelkeznek, ezáltal a kontraszt mérhetővé válik, s így a repedések detektálása és jellemzése megvalósítható. Az FMS (Formation MicroScanner) szelvények teljeskörü felvételt képesek nyújtani a jelen lévő repedéspopulációról, információval szolgálva a bezáródott törésekről és foliációról is (Davatzes és Hickman, 2006).

Az elektromos képkészítés két fő alkalmazási területe a repedés- (töréssürüség, orientáció, nyitottság és porozitás becslése) és rezervoár- (réteghatárok, litológia, szedimentáció, rezervoár szerkezet és heterogenitás) jellemzés, melyet a mikroelektródos készülékek nagy felbontású képeinek elemzése tesz lehetővé, a nagyobb szerkezeti elemek érzékelése pedig a makroelektródos technikával lehetséges. A módszer további felhasználási területeként említhető a vetőértékelés, feszültségtér-meghatározás és permeabilitás becslés.

$\mathrm{Az}$ akusztikus és elektromos képkészítő rendszerek mellett léteznek közvetlen optikai készülékek, valamint egyéb azimutálisan érzékeny sürűségmérő eszközök, ám ezek használata a törésrendszer tulajdonságainak leírására korlátozott és jelentős hibával terhelt.

\section{II.2.3.3 CT}

Az eredetileg egészségügyi vizsgálatok végzésére kifejlesztett CT (Computer Tomography) (Hounsfield, 1972) geotudományok terén történő alkalmazása az 1980-as évek elejétől igen széles körben elterjedt. A módszer kifejezetten alkalmas a kőzetanyagok teljes térfogati heterogenitásának - a sűrüségbeli és liotológiai különbségek - kvantitatív és kvalitatív leírására (Geiger és tsai, 2008). 
Ezen kívül a CT mérésekkel labóratóriumi körülmények között, stresszhatásnak kitett kőzetekben megbízhatóan vizsgálhatóak a fluidum-áramlási sajátosságok és permeabilitási viszonyok (Mees és tsai, 2003). A technika nagy előnye, hogy a kőzetminták, magminták roncsolásmentes elemzését teszi lehetővé.

A CT készülékek a felvételek elkészítéséhez röntgensugárzást használnak; a sugarakat film helyett detektorok érzékelik és a keresztmetszeti kép a létrehozott villamos jelekből készül el. A módszer a sugárgyengítés törvényén alapszik, mely szerint az anyagra jellemző sugárgyengítési együttható az elem rendszámán és a sugárzás spektrumán kívül arányos az anyagsűrüséggel. A detektorok forgó mozgásuk közben nagyszámú mérést, úgynevezett projekciókat készítenek. A jelek ezután mátrixba rendeződnek oly módon, hogy a mátrix minden egyes elemének értéke az adott kőzettérfogati egység sugárgyengítésével lesz egyenlő. Végül minden egyes értéket az úgynevezett Hounsfield skálának megfelelő HU (Hounsfield Unit) értékhez rendelünk. A skála fix pontjait a víz $(H U=0)$ és a levegő (HU=-1000) jelenti, a maximum HU=3000-nél van. Ezzel a megfeleltetéssel a rekonstruált CT kép már megjeleníthetővé válik, és speciális, pl. ablakolásos technikával kiértékelhető.

A modern készülékek térbeli felbontása 20 vonalpár/cm feletti, kontrasztfelbontására pedig jellemző, hogy 3-5 mm nagyságú objektum látható 3 HU különbséggel. Ezzel szemben a mikro CT-k felbontása már megközelíti a mikrométeres mérettartományt, bár ez esetben a vizsgálható minta mérete is jelentősen korlátozott (2.3 táblázat).

\begin{tabular}{lcc}
\hline \multicolumn{1}{c}{ Típus } & Vizsgálati mérettartomány & Felbontás \\
\hline Hagyományos orvosi CT & $\mathrm{m}$ & $\mathrm{mm}$ \\
Magas felbontású CT & $\mathrm{dm}$ & $100 \mu \mathrm{m}$ \\
Ultra magas felbontású CT & $\mathrm{cm}$ & $10 \mu \mathrm{m}$ \\
Mikrotomográfia & $\mathrm{mm}$ & $\mu \mathrm{m}$ \\
\hline
\end{tabular}

2.3 táblázat Különböző típusú CT készülékek és jellemző felbontásuk (Carlson és tsai, 2003).

\section{II.2.3.4 2D, 3D szeizmika}

A szeizmikus kutatómódszer a szekvenciasztratigráfiai vizsgálatok, a fáciesanalízis és a $\mathrm{CH}$ csapdák illetve indikátorok kijelölése mellet kiválóan alkalmas a földtani szerkezetek feltérképezésére is. Szeizmikus mérések végzésekor mesterséges rezgéseket keltünk a földben, majd a mélyből visszaérkező rugalmas hullámokat regisztráljuk. Az észlelt beérkezésekből elsősorban a különböző akusztikus impedanciájú rétegek határainak elhelyezkedésére tudunk következtetni. A folytonosan követhető reflexiós vonalak kirajzolják a deformált geológiai szerkezeteket, míg adott reflexió mentén előforduló szakadások általában vetők jelenlétére utalnak. 
A CH, illetve geotermikus kutatásokhoz adott esetben elegendő lehet a 2D szeizmikus vonal menti felvételek alkalmazása. Ha nemcsak a nagyobb, regionális skálán észlelhető vetőket akarjuk nyomon követni, hanem a méteres tartományban is fel kívánjuk térképezni a rezervoárt, akkor a lényegesen nagyobb felbontást ( $25 \mathrm{~m}$ ) eredményező területi (3D-s) mérések nyújtanak megoldást. A felmérés során az adatok 3D rácsban kerülnek felvételre, eredménye a 3D adatkocka.

A 3D szeizmikus adatokon a repedésrendszer feltérképezésére nemcsak a hagyományos, manuális, sokszor szubjektív értelmezés létezik, hanem speciális attribútum vizsgálatok is végezhetők. Egyik ezek közül az úgynevezett koherencia-vizsgálat (Bahorich és Farmer, 1995), ami lehetőséget ad komplex vetőrendszerek kimutatására a szeizmikus hullámok folytonossági hiányai alapján, de a görbület, dőlés és azimut, vagy a hasonlóság is olyan tipikus szeizmikus attribútumok, melyek azonosítani és kiemelni képesek a szeizmikus adattömb pontjaiban számított térbeli szakadásokat (Pepper és Bejarano, 2005). A legújabb technológiai fejlesztések közül az automatizált, nagy felbontású ( 5 m) repedésfelismerő algoritmusokat (Oppermann, 2012) melyek az amplitúdó, periódus vagy gyakoriság térbeli változásának fizikai mérésén alapul - egyre nagyobb sikerrel alkalmazzák a szénhidrogéniparban, a szén- és ércbányászatban, valamint a geotermikus energiaiparban.

\section{II.2.3.5 Felszíni kibúvások}

Bizonyos esetekben a mélybeli szerkezeti elemek megfigyelésére, mérésére felszíni kibúvásokban közvetlen módon is lehetőség adódhat (ld. III.1.2.4 fejezet, erdősmecskei gránit). Ilyenkor még célszerübb a kőzetformációról készített digitális fényképeken elvégezni a repedésparaméterekre vonatkozó méréseket, illetve statisztikai számításokat. A formáció repedéshálózatára jellemző hosszúságeloszlás és repedéssürüség az esetek többségében megbízhatóan mérhető, míg a nyitottság meghatározásával járó bizonytalanságok a terepen korrigálhatók, illetve az áldőlések számszerüsítésére is általában további vizsgálatok szükségesek. Felszíni kibúvásokban a repedések durván egy nagyságrendnyi mérettartományon vizsgálhatók a leképezés távolságától függően (pl. néhány 10 cm-től néhány m-es hosszúságig). 


\section{II.3. Modellezési technikák}

A matematikai modellezés hasznos eszközt nyújt a repedezett-porózus rezervoárok tanulmányozásához, segítségével mind a repedéshálózat szerkezeti geometriája, mind a törések orientációja, intenzitása, a kőzetek töréses alakváltozási mechanizmusa, vagy éppen a fluidum alapvető szivárgási sajátosságai előrejelezhetők. A matematikai modellek - a rendszer viselkedését a matematika nyelvén leíró absztrakt sémák - megoldása kétféleképpen, analitikus vagy numerikus úton lehetséges. Az analitikus modell egzakt, matematikai megoldást ad az adott problémára, melyet a geometriai komplexitás és belső anyagi tulajdonságok szempontjából mindig bizonyos fokú korlátozottság jellemez. Ezzel szemben a numerikus modell közelítő, nem egzakt megoldásokat kínál fel, melyek mind időben, mind térben szakaszolják a lezajló folyamatokat. Alkalmazásukkal jobban kezelhetők az olyan geológiai esetek, ahol a - valóságot hűen közelítő nagyszámú fizikai változóval leírt komplex problémát vizsgálunk. A mindennapi gyakorlatban a numerikus modellezés három közvetlen formája a véges elemes-, véges differencia- és véges térfogat-módszerekben nyilvánul meg.

A véges differencia elve leginkább olyan problémákra nyújt hatékony megoldást, ahol valamilyen anyag mozog keresztül a számítási hálón, miközben a csomópontok elrendezése állandó marad a modellezés során. A módszer alapgondolata az adott fizikai folyamatot leíró alapegyenletek (differenciálegyenletek) differencia-egyenletté való átalakításában rejlik. A számítások úgy történnek, hogy a modellezni kívánt teret egyenletes vagy változó osztású rácshálóval téglatest alakú elemekre osztjuk. A modelleknek ez a csoportja ideális fluidum-áramlás, transzport, vagy szeizmikus hullámterjedési vizsgálatokhoz.

A véges elemes módszerben a modellezendő folyamat térbeli és időbeli előrehaladtával a számítási háló elemei változásra, deformációra képesek. A módszer alapötlete a lokális közelítés elve, miszerint az egyes elemek helyén leírni kívánt tulajdonságokat előre parametrizált függvényekkel közelítjük. A lokálisan meghatározott közelítő függvényeket a szomszédos elemek határai mentén illesztjük, így végül a teljes vizsgálati tartományra állítjuk elő a folytonos approximációs mezőt (Kovács, 2004). Az említett tulajdonságai révén a véges elemes technika a szerkezeti változások, természetes repedezettség előrejelzése terén jut legnagyobb előnyhöz, szemben az előző módszerrel. A diszkrét elemek (repedések, vetők) rugalmasan beépíthetők, emiatt bonyolultabb tektonikai szituációk fluidum-szivárgás és transzport modellezésére is kiválóan alkalmas.

A véges-térfogat egy olyan, talán kevésbé használatos diszkretizálási módszer, ami kiválóan alkalmas a különböző típusú megmaradási törvények numerikus szimulációjára. Legfontosabb 
tulajdonságaiban hasonlít a véges elemes módszerhez, tetszőleges geometriájú rendszer esetében használható, illetve szabályos vagy szabálytalan számítási hálót egyaránt alkalmazhatunk. A véges térfogat módszer lokálisan konzervatív, ugyanis egyensúlyi megközelítésen alapul: minden egyes diszkretizációs cellán helyi egyensúlyt hoz létre. Differencál-egyenleteinket az egyes elemi cellák térfogatára integrálva az összes részfelületére vonatkozó felületi integrált kapjuk meg, s végül iteratív közelítő eljárások alkalmazásával jutunk az egyenletrendszer megoldásához.

A fent említett modellezési módszereknek a szimulációs szoftverek körében számos elterjedt képviselője ismert (2.4 táblázat).

\begin{tabular}{|c|c|c|c|c|}
\hline $\begin{array}{l}\text { Program } \\
\text { kód }\end{array}$ & Diszkretizáció & Szivárgási folyamatok & Transzport folyamatok & $\begin{array}{l}\text { Általános } \\
\text { tulajdonságok }\end{array}$ \\
\hline Feflow & Véges elemes & $\begin{array}{l}\text { Lamináris Darcy } \\
\text { Törések (Darcy v. } \\
\text { Hagen-Poiseuille) }\end{array}$ & $\begin{array}{l}\text { Hőtranszport } \\
\text { Többösszetevős } \\
\text { transzport }\end{array}$ & A, B, D \\
\hline Fracas & Véges térfogat & $\begin{array}{l}\text { Lamináris Darcy } \\
\text { Törések (turbulens) }\end{array}$ & $\begin{array}{l}\text { Hötranszport } \\
\text { Többfázisú transzport }\end{array}$ & $\mathrm{D}, \mathrm{E}$ \\
\hline Rockflow & Véges elemes & $\begin{array}{l}\text { Lamináris Darcy } \\
\text { Nem lineáris Darcy } \\
\text { Törések (turbulens) }\end{array}$ & $\begin{array}{l}\text { Hőtranszport } \\
\text { Többfázisú transzport } \\
\text { Többösszetevős } \\
\text { transzport }\end{array}$ & $\mathrm{A}, \mathrm{B}, \mathrm{D}$ \\
\hline Shemat & $\begin{array}{l}\text { Véges } \\
\text { differencia }\end{array}$ & Lamináris Darcy & $\begin{array}{l}\text { Hőtranszport } \\
\text { Többösszetevős } \\
\text { transzport }\end{array}$ & A, B \\
\hline Sutra3D & Véges elemes & Lamináris Darcy & $\begin{array}{l}\text { Hőtranszport } \\
\text { Többösszetevős } \\
\text { transzport }\end{array}$ & A, B, D \\
\hline Tough2 & $\begin{array}{l}\text { Véges } \\
\text { differencia }\end{array}$ & Lamináris Darcy & $\begin{array}{l}\text { Hőtranszport } \\
\text { Többösszetevős } \\
\text { transzport }\end{array}$ & $\mathrm{A}, \mathrm{B}, \mathrm{C}, \mathrm{D}$ \\
\hline
\end{tabular}

2.4 táblázat Különböző numerikus modellező szoftverek fő tulajdonságai (A: ekvivalens kontinuum modellek, B: kettős porozitás modellek, C: sztochasztikus folytonos közeg, D: determinisztikus diszkrét repedésmodellek, E: sztochasztikus diszkrét repedésmodellek) (Kohl és tsai (2007) nyomán).

\section{II.3.1 Repedéshálózat-modellezés}

Általánosságban kijelenthető, hogy a nagy mélységben elhelyezkedő kőzetegyüttesek repedésrendszereinek extenzív mintavételezése igen nehézkes és drága műveleteket rejt magában. 
Emiatt az egyetlen járható út, ami a korlátozottan rendelkezésre álló adatokra támaszkodva mégis segít a döntéshozási folyamatban, az a matematikai modellezés.

Szükségességének alapja: mivel a fluidum mozgása több mérettartományban - mikro/mega - egyszerre valósul meg, így a keretet adó modellnek is tartalmaznia kell az adott töréshalmazt ezen a széles skálán.

\section{II.3.1.1 Repedéshálózat-modellezési megközelítések}

A kőzettestekben kialakuló repedéshálózat és abban lejátszódó felszín alatti vízáramlás matematikai modellezésére két eltérő megközelítés ismert. Az egyik csoportba tartozó modellek a közeget ekvivalens kontinuumként ábrázolják, míg a másik kategóriát a diszkrét hálózat modellek alkotják. Ezenkívül létezik egy harmadik, úgynevezett hibrid technikát alkalmazó modell, mely az előző két módszer bizonyos tulajdonságait ötvözi (2.5 táblázat).

\begin{tabular}{|c|c|c|}
\hline Modell-csoport & Modell & Fö paraméterek \\
\hline \multirow{3}{*}{ Ekvivalens kontinuum modellek } & Egyszeri porozitás-modellek & $\begin{array}{l}\text { Effektív porozitás, permeabilitás } \\
\text { tenzor }\end{array}$ \\
\hline & $\begin{array}{l}\text { Kettős porozitás- (permeabilitás-) } \\
\text { modellek }\end{array}$ & $\begin{array}{l}\text { Mátrix porozitás és permeabilitás, } \\
\text { mátrix-repedés kölcsönhatás }\end{array}$ \\
\hline & $\begin{array}{l}\text { Sztochasztikus kontinuum- } \\
\text { modellek }\end{array}$ & $\begin{array}{l}\text { Permeabilitás geostatisztikai } \\
\text { paraméterei }\end{array}$ \\
\hline \multirow{4}{*}{$\begin{array}{l}\text { Diszkrét repedéshálózat (DFN) } \\
\text { modellek }\end{array}$} & $\begin{array}{l}\text { Egyszerü felépítésü } \\
\text { repedéshálózat-modellek }\end{array}$ & $\begin{array}{l}\text { Hálózati geometria statisztikák, } \\
\text { repedés-vezetőképesség eloszlás }\end{array}$ \\
\hline & $\begin{array}{l}\text { Mátrix porozitással rendelkező } \\
\text { repedéshálózat-modellek }\end{array}$ & $\begin{array}{l}\text { Hálózati geometria statisztikák, } \\
\text { mátrix porozitás és permeabilitás }\end{array}$ \\
\hline & $\begin{array}{l}\text { Repedéshálózat-modellek a } \\
\text { törések közötti térbeli kapcsolat } \\
\text { megjelenítésével }\end{array}$ & $\begin{array}{l}\text { Repedés növekedés, hálózat } \\
\text { fraktál tulajdonságai }\end{array}$ \\
\hline & $\begin{array}{l}\text { Ekvivalens diszkontinuum- } \\
\text { modellek }\end{array}$ & $\begin{array}{l}\text { Ekvivalens vezetőképes } \\
\text { rácselemek }\end{array}$ \\
\hline \multirow[t]{2}{*}{ Hibrid modellek } & $\begin{array}{l}\text { Diszkrét hálózati vizsgálaton } \\
\text { alapuló kontinuum- } \\
\text { megközelítések }\end{array}$ & $\begin{array}{l}\text { Hálózati geometria statisztikák, } \\
\text { repedéstranszmisszivitás-eloszlás }\end{array}$ \\
\hline & Statisztikai kontinuum-transzport & $\begin{array}{l}\text { Hálózati geometria-statisztikák, } \\
\text { repedéstranszmisszivitás-eloszlás }\end{array}$ \\
\hline
\end{tabular}

2.5 táblázat Áramlási- és transzport-modellek csoportosítása a modellszerkezetben megjelenő heterogenitás alapján (Committee on Fracture Characterization and Fluid Flow, 1996).

A kőzettestekre jellemző fluidum-áramlási sajátosságok eredettől, kőzettani összetételtől, szerkezettől és a vizsgálat mérettartományától függően csak bizonyos fokú heterogenitás mellett 
jellemezhetők. Ez a féle heterogenitás sokkal erősebben jelentkezik, amennyiben az adott kőzet fejlett repedéshálózattal rendelkezik. A modellezési eljárások közötti alapvető szemléletbeli különbség éppen ennek a heterogenitásnak a kezelésében rejlik.

\section{Ekvivalens kontinuum-modellek}

A hagyományos ekvivalens kontinuum-módszer a repedezett közeg heterogenitásának modellezését egységes tulajdonságokkal jellemzett, limitált számú régió kijelölésével valósítja meg. Az egyedi töréseket a rendszer nem kezeli explicit módon, továbbá nem veszi figyelembe a reprezentatív elemi térfogat és a skála-invariancia kérdését. A kőzet hidrodinamikai tulajdonságai koefficiensekkel (pl. effektív porozitás, permeabilitás) vannak kifejezve, melyek a legtöbb repedés térfogatra átlagolt viselkedését adják meg.

A modell determinisztikus, ha a szivárgás és transzport leírásakor a változók legvalószínűbb értékeit használjuk fel. A legelterjedtebb gyakorlat a kontinuum-féle megközelítés determinisztikus keretek között történő alkalmazása. Ezzel szemben a modellt sztochasztikusnak nevezzük, amennyiben az együtthatókat - melyek eloszlását valamilyen valószínűségi függvény ír le - térben változó random mezőn vizsgáljuk.

A determinisztikus kontinuum-módszerben az átlagolt térfogatnak elég nagynak kell lenni ahhoz, hogy statisztikailag reprezentatív mintát foglaljon magába a nyitott, egymással kapcsolatban lévő törések halmazán. Ez egyben azt is jelenti, hogy a fluid-fluxust, illetve transzportot jelentős mértékben nem befolyásolják a vezető repedéshálózatot alkotó egyedi törések. Az áramlási tér egységes szivárgási tulajdonságokkal való reprezentációja olyan esetekben alkalmazható jól, amikor a megoldandó probléma léptéke nagy, a törések összefüggő hálózatot alkotnak, és az érdeklődés a térfogati áramlásra koncentrálódik.

A telített zónában a repedések rendszerint az elsődleges útvonalat jelentik a szivárgás és anyagszállítás szempontjából. A jól vezető törések közötti mátrix ehhez hozzájárulva, jelentősen növelheti a kőzet tárolási tulajdonságait. A repedezett közeget leíró ekvivalens kontinuummodelleknek két elterjedt típusa az egyszeri (Carrera és tsai, 1990) és kettős (Pruess és Narasimhan, 1988) porozitás modellek. A fő különbség abban rejlik, hogy míg az előzőben a porozitás kizárólag a repedésekhez kötődik, és a mátrix porozitás elhanyagolható, addig az utóbbi esetben a vezető törések közötti mátrix-blokk is rendelkezik pozitív hézagtérfogattal.

\section{Diszkrét hálózat-modellek}

A diszkrét hálózat-modellek elve azon a feltételezésen alapul, hogy a törések szivárgási sajátosságai a repedés-geometria és egyedi transzmisszivitás-értékek ismeretében kellő biztonsággal 
számítható. A módszer alapelve, hogy a repedéshálózathoz társuló, mérhető adatokból - terepen vagy laboratóriumi körülmények között mért fizikai (permeabilitás) és matematikai (térbeli sủrüség, kiterjedés, orientáció) tulajdonságok - kapott térbeli statisztikai eloszlások felhasználásával azonos térbeli tulajdonságokkal rendelkező repedéshálózat-realizációk generálhatók. Az egyes realizációkban éppen a törések lesznek a fluidum-áramlás fő vezető csatornái (Long és tsai, 1982; Dershowitz, 1984).

A diszkréthálózat-modellezés valójában szorosan kapcsolódik a sztochasztikus szimuláció fogalmához, ahol a fő paraméterek statisztikai eloszlásai alapján generált, azonosan valószínü repedéshálózat-realizációkra áramlási egyenletrendszerek sokaságát kell megoldani a hidraulikus emelkedési magasságok számításához. A Monte Carlo szimulációban ugyanazon sztochasztikus modell-realizációhoz tartozó szivárgási jellemzők (pl. fluid fluxus, vagy szennyező anyag elérési idők) átlagolásával levonhatjuk a következtetéseket a rendszer egészének megjelenéséről, valamint az átlag- és hozzájuk tartozó szórásértékek változékonyságáról.

A diszkréthálózat-modellek alkalmazásához elengedhetetlen a 3D szimulációs képesség. Ezekben a modellekben a töréseket leggyakrabban korong formájú, vagy poligon alakzatok ábrázolják. A módszer egyik nagy előnye, hogy különnemü geológiai, geofizikai és fluidumtermelési adatok sokaságát képes konzisztens módon együtt kezelni, amire például a hagyományos kettős porozitás-modellek ilyen mértékben nem alkalmasak.

A DFN (Discrete Fracture Network) modellezési technika az egyik leghatékonyabb módja a repedezett közegben történő felszín alatti vízáramlás elemzésére, azonban ez a megközelítés nem alkalmas regionális léptékü problémák megoldására. A DFN modelleknek igen nagy számítási igényei vannak, ami miatt alkalmazásuk a kisebb mérettartományok megjelenítésére korlátozódik. Éppen ezért gyakran vetődik fel az igény, hogy más rendszerekkel (pl. sztochasztikus kontinuum) kapcsoltan, azok számára input adatot szolgáltatva nyújtsanak eszközt a rezervoár méretü hidrodinamikai rendszerek modellezéséhez.

A 3D hálózat-modelleknek három általánosan elterjedt csoportját különböztethetjük meg: félig-analitikus modellek, térben elrendezett 1D áramlási csatornák modellje és a 2D diszkrét repedéssíkok modellje.

\section{Hibrid modellek}

A hibrid modellek az előző két modelltípus előnyeit kihasználva szimulálják és teszik elemezhetővé a repedéshálózatot valamely DFN algoritmus alapján (Cacas és tsai, 1990). Mivel a nagy léptékü permeabilitás közvetlenül csak nehezen vagy egyáltalán nem mérhető, a legjobb megoldást a kis léptékben mért permeabilitás-adatokból generált átlagértékkel való következtetés 
jelenthetné. Repedésrendszerek esetén a diszkontinuum-modellek megfelelő keretet adnak az efféle kísérletekhez. Ha a diszkontinuum-modell felépíthető a mért terepi adatokból, akkor a nagy léptéken értelmezett kontinuum tulajdonságok is számíthatók lesznek. Ennek a következtetésnek az igazolására kétféle megközelítés ismert. Az első esetben tulajdonképpen numerikus áramlási kísérleteket végzünk el repedéshálózat-modellek használatával, a második megközelítés pedig a repedéshálózatot perkolációs kérdésként értelmezi, s ez alapján következtet a kontinuumtulajdonságokra.

\section{II.3.1.2 A RepSim és az alkalmazott algoritmus}

A RepSim (M. Tóth és tsai, 2004; M. Tóth, 2010) szoftverkód is egyike azoknak a repedéshálózat-szimulációs eszközöknek, melyek a II.3.1.1 fejezetben már bemutatott fraktál geometria alapú DFN algoritmust használják. Ennek megfelelően a diszkrét töréselemeket reprezentáló korongok halmaza a következő rekurzív módszer alapján történik:

- elsőként történik meg a vizsgált térfogat homogén tulajdonságokkal rendelkező rácselemekre osztása;

- ezután az $i$-edik lépésben kapott blokkok további $n(\in N)$ darab egységre oszlanak, következésképpen $n^{3}$ darab egyenlő méretü $(s / n)$ blokkot kapunk;

- a hálózatra jellemző, input paraméterként beadott fraktál dimenzió alapján $\left(N(s)=s^{-D}\right)$ azok a homogén grid blokkok kerülnek véletlenszerüen kiválasztásra, melyek tartalmaznak repedésközéppontot;

- a 2. és 3. lépés rekurzív ismétlése;

- az előre definiált küszöbérték meghaladtával a törésközéppontot tartalmazó blokkok lesznek a törésközéppontok képviselöi;

- az adott eloszlásokból választott random hosszúság és orientáció értékek felhasználásával generálódnak a középpontok körül a töréseket reprezentáló korongok;

- a (2) egyenlet felhasználásával minden egyes repedéshez nyitottság értéket számít a program.

Az 1-4. lépések ismétlődésekor a töréscentrumokat tartalmazó elemek száma párhuzamosan növekszik a felbontás finomításával. A beépített rekurzív algoritmus és box-dimenziónak köszönhetően a kapott pontok halmaza fraktálszerüen viselkedik. A repedéshálózat végső kimeneti formája megegyezik a kezdeti elvárásokkal, miszerint ennek paraméterei egyenlőek lesznek az eredeti töréshalmaz felvett paraméter-eloszlásaival. Az algoritmus sztochasztikus is abban az értelemben, hogy meghatározott számú azonosan valószínü realizációt kapunk. A modellezett 
töréshálózat porozitásának és permeabilitásának számítására a Repsim beépített algoritmussal rendelkezik, míg az olyan attribútumok, mint a repedéshálózat összefüggősége, vagy a reprezentatív elemi térfogat, további vizsgálatokkal származtathatóak.

A program a repedezett porozitást a töréseket reprezentáló korongok és az azt befoglaló rácselemek térfogatának arányából származtatja a következő kifejezéssel:

$$
\phi=\frac{V s}{V}
$$

Kocka rácselemek esetén $V=s^{3}$, míg a töréselemek által kitett térfogat az adott oldalhosszúságú törést tartalmazó blokkok véges integráljával közelíthető. Amennyiben kellően finom rácsfelbontást alkalmazunk, az integrál az alábbi Riemann összeggel fejezhető ki:

$$
V_{f}=\sum_{i=1}^{n} \sum_{j} \frac{l_{i j} \cdot a_{i j} \cdot s}{n},
$$

a porozitás pedig a következőképpen alakul:

$$
\phi=\frac{1}{n \cdot s^{2}} \sum_{i=1}^{n} \sum_{j} l_{i j} \cdot a_{i j} .
$$

A permeabilitás tenzor meghatározásához használt algoritmust M. Tóth (2008) dolgozta ki, s mivel - mint azt majd látni fogjuk - a program által számított értékek a modellezési munkám fontos bemenetét jelentik, a lényegesebb lépéseket röviden itt is bemutatom.

Töréshálózatok esetében - porózus közegekhez hasonló módon - a fluidum-áramlást alapvetően a nyomásviszonyok befolyásolják, az áramlási irányokat azonban repedések térbeli orientációja határozza meg. 3D-ben tehát a permeabilitás tér az irányultságtól függő anizotrópiát mutat, mely 3·3-as permeabilitás tenzorral határozható meg. Ennek számításához először is a Darcy törvényt vesszük alapul:

$$
q_{i}=\frac{g}{\mu} \cdot \rho \cdot k_{i, j} \cdot i_{i}
$$

ahol $q_{i}[\mathrm{~m} / \mathrm{s}]$ a fajlagos vízhozam, $g\left[\mathrm{~m} / \mathrm{s}^{2}\right]$ a gravitációs állandó, $\mu[\mathrm{kg} / \mathrm{m} \cdot \mathrm{s}]$ a dinamikus viszkozitás, $\mathrm{k}\left[\mathrm{m}^{2}\right]$ a permeabilitás és $i[-]$ a hidraulikus gradiens. Mivel repedezett közeg esetén a szivárgás elsősorban a repedések mentén valósul meg, így ez esetben

$$
q_{i}=\frac{1}{V} \cdot \int v_{i}^{f} \cdot d V^{f}
$$


teljesül adott $V$ térfogat felett, ahol $v_{i}^{f}$ a szivárgási sebességet jelenti az i-dik törésben, melyet jól közelíthetünk a következő kifejezéssel:

$$
q_{i}=\frac{1}{V} \cdot \sum_{f} v_{i}^{f} \cdot V^{f}
$$

A viszkózus, összenyomhatatlan folyadék repedésben történő lamináris áramlásának egyenletét a köbös törvény (Lomize, 1951; Snow, 1965; Bear, 1972) írja le, mely szerint a "parallel plate" modellben (Witherspoon és tsai, 1980)

$$
v_{i}^{f}=\frac{a^{2}}{12} \cdot \frac{g \cdot \rho}{\mu} \cdot J_{i}^{f},
$$

továbbá az i-dik törés mentén jellemző hidraulikus gradiens

$$
J_{i}^{f}=\sum_{f}\left(\delta_{i j}-n_{i} n_{j}\right) \cdot J_{j},
$$

ahol $\delta_{i j}$ a Kronecker delta, $n$ a repedéssíkra merőleges egység normál vektor, valamint $i=1,2$, 3 és $j=1,2,3$. A területtel és transzmisszivitási értékkel súlyozott egyedi törések hozzáadásával meghatározott rácselemre empirikus repedés tenzor fejezhető ki az alábbi módon:

$$
F_{i j}=\frac{1}{V} \cdot \sum_{k=1}^{N} A_{k} \cdot T_{k} \cdot n_{i k} \cdot n_{j k}
$$

ahol $F_{i j}$ a repedés tenzor, $A_{k}$ a k-dik törés alapterülete, $T_{k}$ pedig a k-dik repedés transzmisszivitását jelöli.

Az Oda (1985) féle permeabilitás tenzor az $F_{i j}$ - ből származtatható azzal a feltevéssel, hogy az $F_{i j}$ a repedés menti szivárgást a törés egység normál vektoraként fejezi ki. Feltéve, hogy az adott repedés impermeábilis a normálvektorával párhuzamos irányokban, $F_{i j}$ a következőképpen forgatandó a permeábilitási síkokba:

$$
k_{i j}=\frac{1}{12} \cdot\left(F_{k k} \cdot \delta_{i j}-F_{i j}\right) .
$$

\section{II.3.1.3 További repedéshálózat szimulátorok}

A főleg olaj- és gázkutatásban használatos Petrel 3D rezervoár modellező szoftvercsomag a DFN technikát alkalmazza, ami az iparban a legmegbízhatóbb módszernek számít a törések jellemzése terén. Ez a modell jól ötvözi a determinisztikus és sztochasztikus elemeket, továbbá valósághủen szemlélteti a törések közötti kapcsolódás szabályszerüségeit. Müködésében a repedések egyes tulajdonságait és a hálózat geometriáját leíró statisztikai modell elkészítése után, a - meghatározott paraméterhalmazzal jellemzett törések a 3D térben sík felületekként lesznek 
integrálva. Az objektumok mérettartományának definiálása itt elengedhetetlen, amit ezután fel kell skálázni a szimulációs háló méretéhez.

A Roxar cég FracPerm nevü (Roxar, 2005) integrált repedés modellező programja a kút közvetlen környezetében mérhető adatokból indul ki, s megfelelő extrapolációs trendek felhasználásával vetíti ki a töréshálózat tulajdonságait a tágabb rezervoárra. A fluid áramlás modellezésére effektív permeabilitás térképek készülnek a jellemző repedéseloszlások alapján, magát a töréshálózatot pedig DFN algoritmus segítségével, explicit módon generálja a szimulátor. Saját feszültségtér modellel is rendelkezik a program, aminek köszönhetően a teljes feszültség tenzor alapján készült térképek kontrollálják a törések irányultságát és eloszlását a modellen belül. Repedezett rezervoárok jellemzésére és modellezésére releváns alternatívát jelent a FracaFlow, melynek fejlesztése nagy nemzetközi olajcégek támogatásával valósult meg. A repedések és vetők modellezésére - az előző megoldásokhoz hasonlóan - DFN-t generál a program, mely lehetőséget nyújt dinamikus teszt szimulációra és optimalizációs körök futtatására is. A töréshálózat paramétereinek (pl. permeabilitás, cella méret) számítása analitikus és numerikus módszerek alkalmazásával valósul meg a lokális vagy teljes skálán, kimenete pedig további közvetlen használatot tesz lehetővé más rezervoár szimulátorok (pl. PumaFlow) számára.

A FracMan (Dershowitz és tsai, 1998) ugyancsak egy elterjedt, DFN alapú rezervoár szimulációs eszköz, mely alkalmas a repedésrendszerre jellemző anizotrópia és összefüggőség digitális feldolgozására. A repedésparametrizálás sokféle forrás alapján történhet, mint például szeizmikus attribútumok, jelleggörbék, szerkezeti modellek, vagy felszíni kibúvások vizsgálatával. A kalibrált DFN modellen azután számítható a repedezett pórustérfogat és kitermelési tényező (Williams, 2007), ideális kútpozíció tervezhető a jól vezető repedés-csatornák nyomon követésével, valamint maga a DFN modell felskálázhatóvá válik a kettős porozitású rezervoár modell tulajdonságokkal, beleértve az irányított permeabilitás értékek megadását is.

További alternatívaként meg kell említeni a FracNet, Fraca V, FracProPT és fgenv1.c (Riley, 2004) repedéshálózat szimulátorokat.

\section{II.3.2 Porózus közeg modellezése - Felszín alatti vízáramlás és höszállítás}

A repedezett kőzettestekkel ellentétben a porózus képződmények, habár megjelenésük rendszerint hasonlóan heterogén, mégis sokkal egységesebb, folytonosabb áramlási képet mutatnak, s ezáltal mint ekvivalens kontinuum könnyebben kezelhetők. A kontinuum féle megközelítés fogalomkörében igen elterjedtek a már korábban részletezett véges differencia, véges elemes és véges térfogat módszereket használó alkalmazások (2.4 táblázat), melyek a valós áramlási és 
hőmérsékleti teret homogén hidrodinamikai tulajdonságokkal jellemzett egységekkel közelítik, s közöttük a fő különbség az áramlási és transzport egyenletek megoldási módjában rejlik.

Felszín alatti vízáramlás modellezésekor a szivárgás alapegyenletét oldjuk meg a modellezett térfogat nyomásszintjeinek meghatározása érdekében. Telített közegben a permanens szivárgást a Laplace-egyenlet írja le:

$$
\frac{\partial^{2} h}{\partial x^{2}}+\frac{\partial^{2} h}{\partial y^{2}}+\frac{\partial^{2} h}{\partial z^{2}}=0
$$

ahol $h$ a piezometrikus szintet jelöli izotróp áramlási térben.

Ezzel szemben nem permanens esetben, izotróp és homogén közeg esetén a diffúzió egyenlet segítségével adható meg az áramlási tér nyomásszint eloszlása:

$$
\frac{\partial^{2} h}{\partial x^{2}}+\frac{\partial^{2} h}{\partial y^{2}}+\frac{\partial^{2} h}{\partial z^{2}}=\frac{S_{s}}{k} \cdot \frac{\partial h}{\partial t}=\frac{\rho g(\alpha+n \beta)}{k} \cdot \frac{\partial h}{\partial t},
$$

tehát az áramlási térben a nyomásszintek térbeli és időbeli változása a $k$ szivárgási tényezőtől, az $\alpha$ közeg összenyomhatóságtól, az $n$ hézagtérfogattól, a folyadék $\beta$ összenyomhatóságától és $\rho$ sürüségétől függ.

Hőtranszport modellezés esetén a hő terjedését leíró transzport egyenletet kell megoldani a hőmérsékleti mező kiszerkesztéséhez. A hőterjedést a litoszférában a kondukció és konvekció együttesen határozza meg, miszerint hősugárzással a felszín alatt nem számolhatunk. A hővezetés a következő differenciálegyenlettel írható fel:

$$
\frac{\partial t}{\partial \tau}=a \cdot\left(\frac{\partial^{2} t}{\partial x^{2}}+\frac{\partial^{2} t}{\partial y^{2}}+\frac{\partial^{2} t}{\partial z^{2}}\right)
$$

ahol $t$ a homogén izotróp közeg hömérséklete, $d \tau$ a térelem felmelegedése alatt eltelt idő, $a$ pedig a hődiffúzivitási tényező; továbbá

$$
a=\frac{\lambda}{\rho \cdot c}
$$

$\lambda$ a hővezetési tényezőt, $c$ a fajhőt, $\rho$ a sürüséget jelöli.

Ezzel szemben a konvektív hőterjedés általános differenciálegyenlete, vagy más néven Fourier-Kirchhoff-egyenlet képlete

$$
\frac{\partial t}{\partial \tau}+v_{x} \frac{\partial t}{\partial x}+v_{y} \frac{\partial t}{\partial y}+v_{z} \frac{\partial t}{\partial z}=a \cdot \nabla^{2} \cdot t,
$$


ahol $t$ a homogén izotróp közeg hőmérséklete, $d \tau$ a térelem felmelegedése alatt eltelt idő, $a$ a hődiffúzivitási tényező, $\nabla^{2}$ pedig a Laplace-féle másodrendủ differenciáloperátor.

A következőkben bemutatott numerikus szimulátorok egy része csak vízáramlás (pl. Processing Modflow, Sutra), másik csoportja azonban vízáramlás és hőtranszport folyamatok kapcsolt modellezésére (pl. Feflow, Tough2) is alkalmas.

\section{II.3.2.1 A Processing Modflow környezet bemutatása}

A Processing Modflow (Chiang és Kinzelbach, 1999) egy komplex háromdimenziós rendszer a felszín alatti vízáramlás és transzport modellezési feladatok megoldására. A Modflow véges differencia elven müködő hidrodinamikai modellt, professzionális grafikus megjelenítést, fejlett kalibrációs eszközöket, részecske követési modult, valamint transzport modelleket nyújt a felhasználó számára (Kovács, 2004). A program a következő komponenseket tartalmazza:

- intuitív grafikus felhasználói felület az adatbevitel, valamint az eredmények megjelenítési folyamatainak megkönnyítésére;

- 3D véges differencia algoritmust használó felszín alatti vízáramlás modell, tartalmazza a Modflow-96, Modflow-2000, Modflow-2005, és Modflow-NWT verziókat;

- $\quad$ solute transzport modellek (MT3DMS, MT3D, RT3D és MT3D99;

- többkomponensủ reakció transzport modell (PHT3D), ami magába foglalja a 3D advektívdiszperzív transzport modult (MT3DMS);

- változó sủrüségü felszín alatti vízáramlás, több komponensü oldott anyag és hőtranszport modell (Seawat);

- nem lineáris paraméter becslő algoritmusok (PEST);

- szemi-analitikus részecskekövető modul (PMPATH, MODPATH) a felszín alatti vízáramlási irányok és idők számításához;

- vízmérleg kalkulátor;

- heterogén paraméter mező létrehozását biztosító felület a sztochasztikus szimulációhoz;

- beépített, adatpontok közötti interpolációt végző modul.

\section{II.3.2.2 A Feflow modellezö szoftver bemutatása}

A Feflow 6 (Copyright (C) 1979-2009, DHI-WASY GmbH) szoftver (Diersch, 2002) egy felszín alatti vízáramlás, hő- és anyagtranszport modellezésére íródott numerikus szimulátor, mely beépített numerikus megoldói segítségével komplex hidrogeológiai és geotermikus problémakörök vizsgálhatók. A kód 3D grafikus interfésszel rendelkezik, a pre- és post-processzorok a rendszer 
integrált részét képezik. A Modflow-val ellentétben itt a véges elemes módszer jelenti a számítások alapját, melynek köszönhetően számos elönnyel rendelkezik más szimulátorokkal szemben. A térbeli rácsháló például meglehetősen rugalmasan alakítható, az elemek valós geometriához illesztésével a numerikus hibák sokkal jobban kezelhetők. A szoftver fő jellemzői:

- fejlett 3D grafikus alapú modellezési környezet;

- telített és telítetlen szivárgáshidraulikai és szennyeződésterjedés modellezés 2D és 3D megjelenítéssel;

- konvektív, konduktív és termo-diszperzív hőtranszport;

- teljesen tranziens, félig tranziens és permanens szivárgáshidraulikai és transzport folyamatok;

- nyomás alatti és szabadfelületű vízadók ábrázolása;

- celluláris konvekciós folyamatok alkalmazása a dupla diffúziós, valamint a gravitáció és a hő hatására létrejövő konvekció szimulációjára;

- erőteljes végeselemes háló generálási képességek;

- adatbázis és GIS-kapcsolat az adatok hatékony kezelése érdekében;

- integrált adatcsoportosítási rutinok a diszkrét adatok interpolációjához;

- peremfluxusok és transzfer feltételek grafikus hozzárendelése;

- az eredmények megtekintéséhez lehetőséget nyújtó vizualizációs eszközök: kerítésdiagramok, részecskeútvonalak, izofelületek, tetszőleges kivágások, izochronok, modell elforgatás és áramlási vektorok;

- részletes mérlegkészítés: szivárgáshidraulikai, koncentráció és hőáram;

- interfész-menedzser a Feflow és egyéb szoftverek közti kapcsolat megteremtése érdekében.

\section{II.3.2.3 Az alternatívák rövid bemutatása}

A Visual Modflow (Waterloo Hydrogeologic Inc., 2006) a 3D hidrodinamikai és szennyeződés transzport modellezés széles körben elterjedt szabványalkalmazása, mely a Processing Modflow-hoz hasonlóan a véges differencia elvén működik. A program teljesen integrált modellezési környezetet biztosít, amely robosztus kezelőfelület alatt tökéletesen egyesíti a Modflow-2000, a Modpath, az MT3DMS, az RT3D, a Seawat és más programok legújabb verzióit. A Visual Modflow már tartalmazza a hőtranszport modellezéshez szükséges kiegészítőket, illetve a vízkivétel és besajtolás is jóval pontosabban szimulálható a kutak parametrizálásának bővítésével, mint ahogyan az egyébként a Processing Modflow-ban lehetséges. 
A Sutra (Voss és Provost, 2010) egy változó sűrüségü felszín alatti vízáramlás és energia transzport szimulátor, mely 2D és 3D-s problémák megoldására egyaránt alkalmas. A program véges elemes és véges differencia módszert használ az egymástól kölcsönösen függő folyamatokat leíró egyenletek megoldásához. A szimulált esetek a következők lehetnek:

1) fluidum-sűrüségtől függő felszín alatti vízáramlás telített vagy telítetlen közegben, kombinálva vagy

2) (a) oldott anyag transzporttal, vagy

(b) konvektív és konduktív termál energia transzporttal.

A szoftverkód nagy előnye, hogy a közismert Fortran programnyelven íródott, ami könnyü és hatékony beavatkozást tesz lehetővé speciális módosítási igények esetén.

A Tough2 (Pruess, 1991) általános célú numerikus szimulátor program, mely több komponensü és több fázisú fluidumok szivárgási és hőterjedési folyamatainak leírására és megjelenítésére használatos egy, kettő, illetve háromdimenziós porózus és repedezett közegben. Integrált véges differencia módszert használ a térbeli diszkretizáláshoz és időbeli differenciáláshoz, a különböző tulajdonságú és állapotú fluidumokkal végbemenő folyamatok megoldására pedig számos kiegészítő modult kínál. A repedezett-porózus közeg modellezésére a kettős-porozitás, kettős-permeabilitás és a többszörösen egymásra ható közeg (MINC - Multiple Interacting Continua) modelljei közül van lehetőség választani.

Legfőbb felhasználói területek a geotermikus rezervoárkutatás, környezetvédelem, radioaktív hulladék elhelyezés, valamint egyéb, vízadók áramlási és transzport folyamataival kapcsolatos vizsgálatok. 


\section{Repedéshálózatok módszertani elemzése}

\section{III.1. Perkolációs számítások}

A perkoláció kifejezés a latin per (keresztül) és colare (folyni) szavakból tevődik össze. Perkolációról akkor beszélünk, amikor egy struktúra számos, egymással kapcsolatban nem álló alrendszere egy nagy összefüggő egységbe áll össze. Ennek egyik, a mi szempontunkból érdekes földtudományi alapú megfeleltetése az, amikor a kőzet pórusainak vagy repedéseinek egymáshoz kapcsolódását vizsgáljuk a szilárd mátrix anyagban.

E szempont alapján tekintett perkoláció, avagy esetünkben a repedések összefüggősége (Bloomfield, 1996) hidraulikai szempontból a repedéshálózatok egyik leglényegesebb tulajdonsága, mely alapvetően meghatározza a fluidum által bejárható áramlási pályákat. Az összefüggőség kvantitatív kifejezésével gyakorlatilag az effektív porozitásról kapunk információt, azaz az elszigetelt törésklaszterek kizárásával lehatároljuk azt a térrészt, amely a fluidum-áramlásban részt vesz.

\section{III.1.1 A számítások alapja}

Jelenleg nem ismeretes olyan matematikai megoldás, mely a törések jellemző geometriai paraméterei és az összefüggőség kapcsolatát egzakt módon képes lenne leírni. A következőkben olyan módszert mutatok be, mely a RepSim szoftver felhasználásával, tetszőleges input paraméterek megadásával származtatni képes az összefüggő töréshálózatok méretét. A méret kvantitatív leírásához ez esetben az egymást metsző törések számának az összes repedés számához viszonyított százalékos aránya $(P[\%])$ használandó. A cél a $P$ számítása a törésrendszert leíró három független változó, a hosszúságeloszlás $E$ hatványkitevője (2,3), a $D$ fraktál dimenzió (1) és az $\alpha$ relatív dőlés értékei által kifeszített változótér $(E-D-\alpha)$ minden pontjában, majd az így kapott tulajdonságtest részletes jellemzése. Az $E$ és $D$ egyértelmüen jellemzi a töréshálózatot a kívánt szempontból, azonban a repedéssíkok dőlés és csapás értékeinek kétváltozós eloszlása helyett - a számítások átláthatósága érdekében - egy egyszerüsítést alkalmaztam. Adott generációhoz tartozó törések felnyílása mindig a kialakuláskor érvényes feszültségtérrel összhangban történik meg. A II.1 fejezetben részletesebben is kifejtésre került, hogy a főfeszültségek irányától és nagyságától függően általában két markáns térbeli orientációval rendelkező repedéscsoport (2.1 ábra) alakul ki. Hozzá kell tenni, hogy a természetben adott kőzetben több repedésgeneráció is jelen lehet. A két legnépesebb repedéscsoport, valamint a rá jellemző átlagos dőlés/csapás legkönnyebben sztereogrammal, a leggyakoribb értékek kiválasztásával határozható meg; így végül minden 
repedéscsoportot egy konkrét dőlés/csapás értékkel leírható közelítő sík reprezentál. Bár a korábban részletezett szimulációs eljárás során rendszerint dőlés-csapás értékpárok halmazát használjuk, jelen vizsgálatok során a modellben az említett két domináns repedéshalmaz egy-egy közelítő síkjának térbeli szögét, vagyis az $\alpha$ relatív dőlést használtam. A relatív dőlés automatizált számítására rövid programot készítettem Visual Basic programnyelven, melynek forráskódját a D. melléklet tartalmazza. A program két domináns térbeli irányultsággal jellemezhető repedéscsoport esetén számítja a síkok közötti valódi szögeltérést az áldőlés kiküszöbölésével.

A repedések összefüggőségére vonatkozó számítások ezek alapján az $E-D-\alpha(\{-2,8,-2,6$, $\left.-2,4,-2,2,-2,0,-1,8\} ;\{1,3,1,4,1,5,1,6,1,7\} ;\left\{10^{\circ}, 20^{\circ}, 30^{\circ}, 40^{\circ}, 50^{\circ}, 60^{\circ}, 70^{\circ}, 80^{\circ}, 90^{\circ}\right\}\right)$ tulajdonságtest rácspontjaiban készültek el a három alapparaméter értékeinek változtatásával. A pontok értékeinek kombinációjából következően a 270 db paraméterhármas mindegyike esetén legalább 15 független szimuláció történt, melyek során feljegyeztem a maximális méretü perkolációs klaszter elemeinek az összes töréshez viszonyított százalékos arányát. Emellett minden esetben regisztráltam a szórás alakulását is. A sztochaszikus szimulációk során használt további paraméterek, mint a legkisebb $\left(L_{\min }=0,5 \mathrm{~m}\right)$ és legnagyobb $\left(L_{\max }=15 \mathrm{~m}\right)$ modellezett repedés hossza, a hosszúságeloszlás $F(=15)$ paramétere (2) valamint a hosszúság és nyitottság kapcsolatát kifejező $a(=0,004)$ és $b_{2}(=0,368)$ paraméter a futtatások során konstans értéket képviseltek. A vizsgált térfogatot minden esetben egy 100 m élhosszúságú alapkocka reprezentálta.

\section{III.1.2 Diszkusszió}

\section{III.1.2.1 Az összefüggöség változása az E-D- $\alpha$ változótérben}

$\mathrm{Az}$ eredményeket megvizsgálva azt látjuk, hogy az $E-D-\alpha$ tulajdonságtest $\left(E_{-2,8}, D_{1,3}, \alpha_{10}\right)$ csúcsában minimális, $0,1 \%$ alatti, $\left(E_{-1,8}, D_{1,7}, \alpha_{90}\right)$ csúcsában pedig maximális, 99,9\% feletti az összefüggőség. A 10-80\% közötti intervallumot vizsgálva a kapott perkoláció értékek jellegzetes, térben elhajló testet rajzolnak ki az E-D- $\alpha$ változótérben (3.1 ábra). 


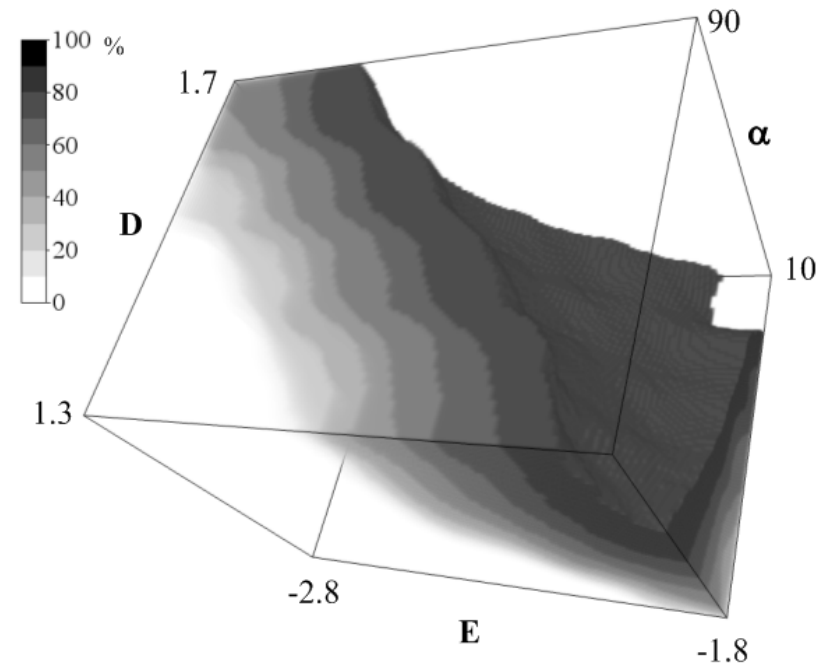

3.1. ábra A legnagyobb perkolációs klaszter relatív méretének alakulása az $E-D-\alpha$ változótérben.

A P $<10 \%$ és P>80\% zónák közötti átmenetet vizsgálva monoton növekvő értékeket tapasztalunk. A paraméter értékek középső tartományában a töréshálózat élesen vált át kis mértékben összefüggőből lényegében teljesen összekapcsolódó rendszerré. Ez a viselkedés igen kifejezően jelenik meg a tulajdonságtest rögzített $E$ paraméterủ szeleteinek átlója mentén készített metszeteken (3.2 ábra).

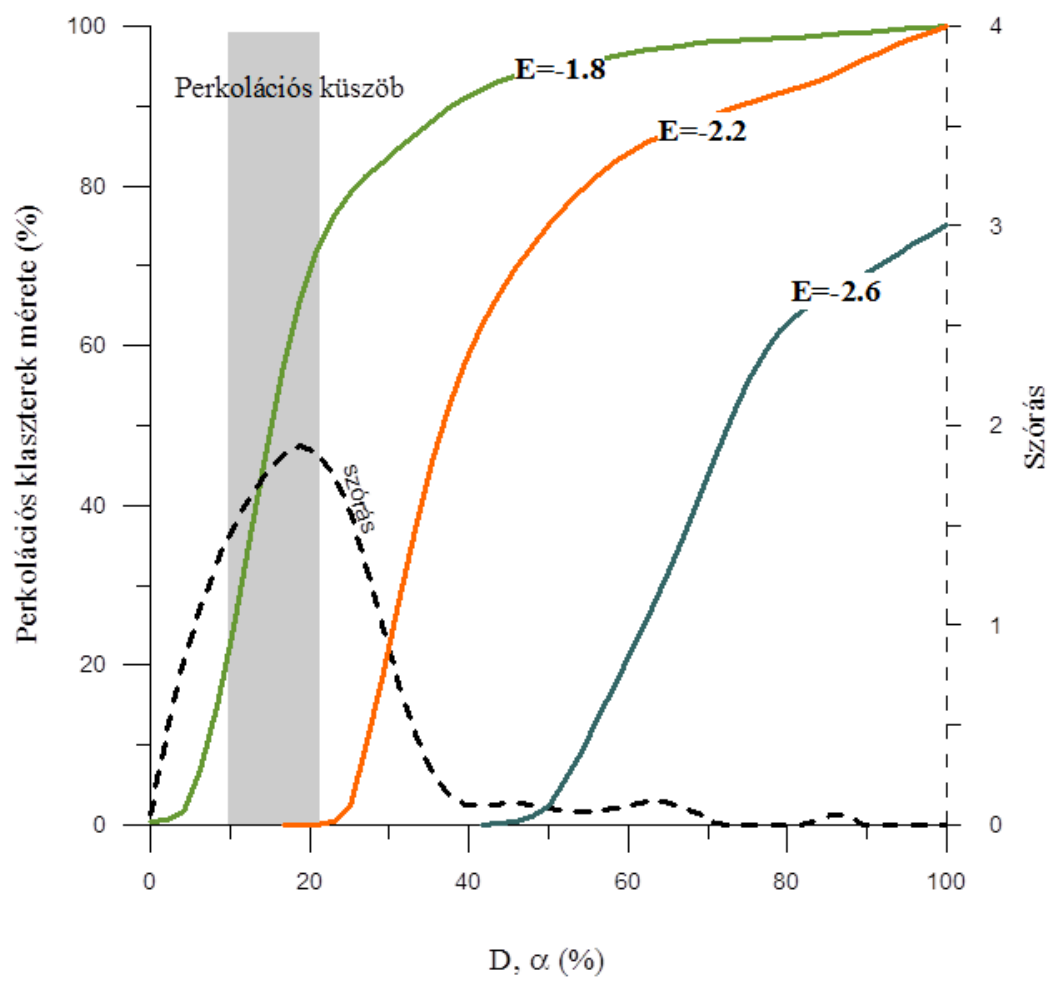

3.2 ábra S-alakú perkolációs görbék a $D$ - $\alpha$ változó sík átlói mentén értelmezett keresztmetszetben. A perkolációs küszöb megjelenése a szórás maximum környékén várható. 
A megjelenített görbék többé-kevésbé jól kifejlett $S$ alakba rendeződnek. Egy-egy görbe monoton növő, korlátos és folytonos (konvergens) az 5\% és 100\% közötti tartományt reprezentáló intervallumon, az ennél kisebb értékek bizonytalanul váltakoznak. A görbék inflexiós ponttal rendelkeznek. Az inflexiós pont szük környezetében a görbe meredeken növekvő jelleget ölt, tőle jobbra és balra pedig enyhén lejt. $\mathrm{Ha} \mathrm{x}_{1}$ és $\mathrm{x}_{2}$ az inflexiós pont közelébe esik, akkor $\left|\mathrm{x}_{1}-\mathrm{x}_{2}\right|$ jóval kisebb, mint $\left|\mathrm{P}\left(\mathrm{x}_{1}\right)-\mathrm{P}\left(\mathrm{x}_{2}\right)\right|$. Ezt a pontot perkolációs küszöbként ismerjük, mely közvetlen környezetében a több részrendszerből álló kisebb csoportok, valamint az egy nagy töréshálózattá rendező teljes rendszer egyaránt jelen vannak. Mivel a perkolációs küszöb környezetében a görbék igen meredek lefutásúak, ebben a tartományban a töréssürüség, töréshosszúság vagy éppen a dőlés minimális változása is alapvetően átrendezheti a repedéshálózat összefüggőségi viszonyait. A küszöbérték mentén elkülönülnek a lényegében nem összefüggő és összefüggő törésrendszerek. $E=-1,8$ értéknél az S-görbe közel ideális alakot ölt, a teljes tartományt átfogja, ellenben $E=-2,6$ esetén P értéke nem haladja meg a $70 \%$-ot, ami azt jelenti, hogy tetszőlegesen nagy $D$ és $\alpha$ esetén sem alakul ki akkora klaszter, amely a törések több mint felét magába foglalná.

A meghatározás bizonytalanságát tovább növeli, hogy a számított szórás értékek a perkolációs küszöbnél érik el maximumukat (3.2 ábra), azaz azonos paraméterhármashoz tartozó különböző realizációk eredménye is lényegesen eltér egymástól.

Az optimális áttekinthetőség érdekében az $E-D$ - $\alpha$ változótér mindhárom tengelyének irányában, minden mért $E, D$ és $\alpha$ értékhez tartozó síkmetszetet nomogramon ábrázoltam a várható érték és szórás esetén egyaránt. A nomogram tulajdonképpen többváltozós függvények síkbeli ábrázolására és az egymáshoz tartozó értékrendszerek megállapítására szolgáló ábra, mely lehetővé teszi adott kőzettest repedéshálózatának jellemzését a legfontosabb törésparaméterek ismeretében. A várható értékek nomogramjai az első és második legnagyobb klaszterre (A. és B. melléklet), míg a szórás nomogramjai a legnagyobb repedéscsoportra készültek el (C. melléklet). A kétdimenziós nomogramok megjelenítésénél a mért pontok között interpolált értékek szerepelnek, valamint egyes esetekben minimális simítási mủveleteket is végeztem. Az A., B. és $C$. mellékletekben bemutatott nomogram sorozatok a következők:

- 1. sorozat: az $\alpha-D$ változó síkbeli várható értékek a legnagyobb törésklaszter relatív méretére vonatkozóan, $E$ paraméter értékei rendre -2,8, -2,6, -2,4, -2,2, -2,0 és -1,8-nál rögzítve;

- 2. sorozat: az E- $\alpha$ változó síkbeli várható értékek a legnagyobb törésklaszter relatív méretére vonatkozóan, $D$ paraméter értékei rendre 1,3, 1,4, 1,5, 1,6 és 1,7-nél rögzítve; 
- 3. sorozat: az E-D változó síkbeli várható értékek a legnagyobb törésklaszter relatív méretére vonatkozóan, $\alpha$ paraméter értékei rendre $10^{\circ}, 20^{\circ}, 30^{\circ}, 40^{\circ}, 50^{\circ}, 60^{\circ}, 70^{\circ}, 80^{\circ}$ és $90^{\circ}$-nál rögzítve;

- 4-6. sorozat: az 1-3. sorozat kikötéseivel, azonban itt a várható értékek a második legnagyobb törésklaszter relatív méretére vonatkoznak;

- 7. sorozat: a $D-\alpha$ változó síkbeli szórás értékek a legnagyobb törésklaszter relatív méretére vonatkozóan, $E$ paraméter értékei rendre -2,8, -2,6, -2,4, -2,2, -2,0 és -1,8-nál rögzítve;

- 8. sorozat: az $E-\alpha$ változó síkbeli szórás értékek a legnagyobb törésklaszter relatív méretére vonatkozóan, $D$ paraméter értékei rendre 1,3, 1,4, 1,5 és 1,6-nál rögzítve;

- 9. sorozat: az E-D változó síkbeli szórás értékek a legnagyobb törésklaszter relatív méretére vonatkozóan, $\alpha$ paraméter értékei rendre $10^{\circ}, 20^{\circ}, 30^{\circ}, 40^{\circ}, 50^{\circ}, 60^{\circ}, 70^{\circ}, 80^{\circ}$ és $90^{\circ}$-nál rögzítve.

\section{III.1.2.2 Perkolációs csoportok}

Az előző, III.1.2.1 fejezetben bemutatott tulajdonságtest és az S-görbék jellege, azaz a perkoláció értékek változása arra enged következtetni, hogy a repedésrendszerek az E- $D$ - $\alpha$ paraméterek függvényében alapvetően három fő perkolációs típusba sorolhatók (M. Tóth és Vass, 2011) - ezeket nevezzük rendre 1., 2., és 3. zónának. A zónák az 3.3 ábrán az E-D- $\alpha$ tulajdonságtest tengelyekkel párhuzamos metszeteként előálló $D$ - $\alpha$ nomogramon kerülnek bemutatásra.

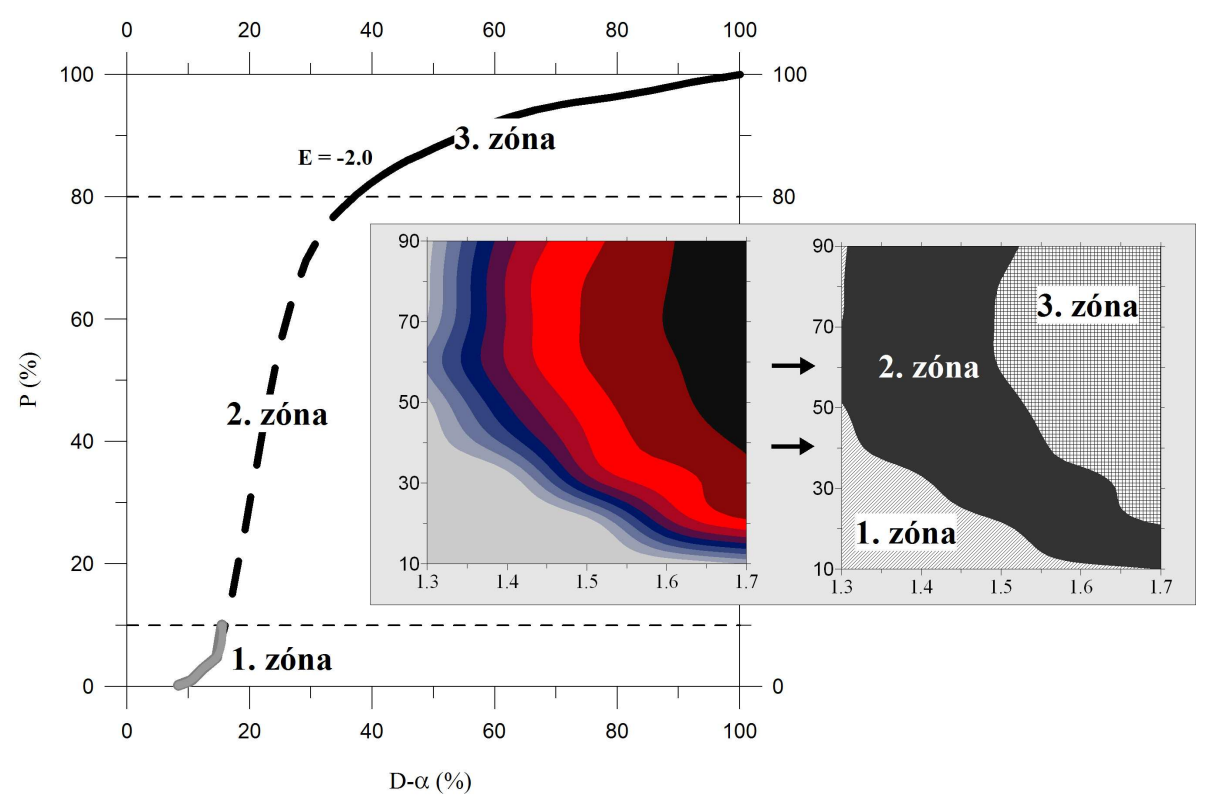

3.3 ábra A három fő perkolációs típus elkülönítése. 1. zóna: a törések kis hányada metszi csak egymást; 2. zóna: a repedéshálózat összefüggősége nehezen megjósolható; 3. zóna: a törések számottevő része kapcsolódik egymáshoz. 
Az első típus (1. zóna) esetében (kis paraméter értékeknél) az összefüggő rendszerek mérete szinte elhanyagolható, az összes repedésnek mindössze egy kis hányada metszi egymást. A zóna területe növekszik mind az $E, D$ és $\alpha$ csökkenésével, és a paraméterek legkisebb értékeinél szinte nem is lesz jelen más a rendszerben, csak önálló, elszigetelt törések. Az E=-2,8 nomogram esetében (A. melléklet, 1. sorozat) például extrém nagy dimenzióértéktől eltekintve nem alakul ki számottevő méretü töréscsoport, bárhogyan is változtatjuk a másik két paramétert. Ezzel szemben magas $E$, $D$ és $\alpha$ értékállásnál a zóna terjedelme minimálisra csökken, különösen $E=-1,8$ vagy $D=1,7$ esetekben. Ebben a zónában a szórás is minimális, általában <1 értéknél stabilizálódik (C. melléklet, 7-9. sorozat).

A második esetben (3. zóna), magas paraméter értékek esetén a törések nagy része összefüggő hálózatot alkot. A repedések több mint 80\%-át magába foglaló perkolációs klaszter alakul ki, s a zónán belül a paraméterek változása csak kis, az egész hálózatot tekintve elhanyagolható módosulást okoz az összefüggőségben. A zóna nagyjából az S-alakú görbe inflexiós pontjától jobbra lévő, enyhe lejtésű résznek felel meg. Magas $E$ értéknél például viszonylag kis $D$ és $\alpha$ mellett is biztosított a kapcsolat a törések több mint $80 \%$-a között. A zónára kis szórásértékek jellemzőek, és számottevő méretű második legnagyobb klaszter kialakulásához már nem marad elegendő repedés.

Az előbbi két típus szimulációja igen megbízható eredményt ad, a különböző realizációk eredményei alapvetően megegyeznek, a szórás mindkét esetben jóval kisebb egynél. A paraméterek meghatározásának bizonytalanságára ezek a repedésrendszer típusok kevéssé érzékenyek, a mérés során szükségszerűen fellépő pontatlanságok alapvetően nem befolyásolják az eredményt.

Ha figyelmen kívül hagyjuk a 0-10\% és 80-100\% tartományokat, akkor egy több vékony sávból álló zónát kapunk, amely közelítően a korábban vizsgált S-alakú görbe meredek lefutású részét reprezentálja. Ez a középső átmeneti tartomány (2. zóna) jellemző töréshálózata az első két zónával alapvetően ellentétes tulajdonságokkal jellemezhető, mely meghatározott vastagsággal és különböző alakot felvéve fut végig az egyes nomogramokon. Az $E$ és $D$ értékeinél rögzített metszeteken (A. melléklet, 1-2. sorozat) a zóna hasonlóan görbült jellegü, az $\alpha$-nál rögzített nomogramokon (A. melléklet, 3. sorozat) pedig átlós irányban, lineárisan haladnak a sávok.

Azon túl, hogy a nagy szórásnak köszönhetően az összefüggő rendszer mérete lényegében nem megjósolható, ez a zóna reagál legérzékenyebben az alapparaméterek mérési bizonytalanságaira is (3.4 ábra). 


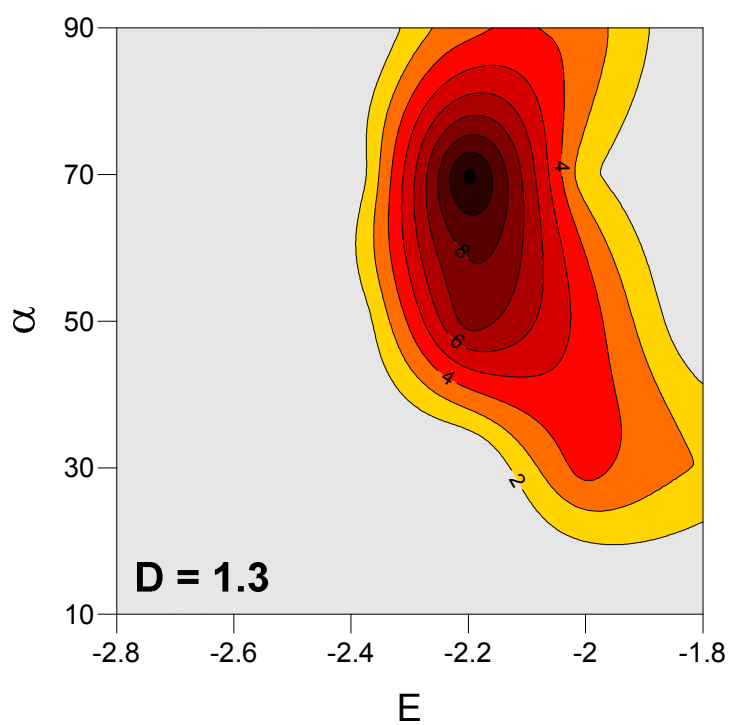

3.4 ábra A legnagyobb perkolációs klaszter relatív mérete szórásának változása. 10\%-os differencia észlelhető a metsző törések számában az $(E, D, \alpha)=(-2,2,1,3,70)$ pontban.

A második legnagyobb repedéscsoport (B. melléklet, 4-6. sorozat) esetében az 1\% feletti relatív méretű tartományok alakja a legnagyobb klaszter előbb tárgyalt érzékeny zónájának lefutását követi. Gyakorlatilag az történik, hogy a paraméterek növelésével elérjük a 2. zóna alsó határát, s innentől az összefüggő repedések száma ugrásszerüen elkezd nőni. Eleinte még marad annyi repedés, hogy több hasonló méretü klaszter alakuljon ki. Például a legnagyobb klaszter a repedések 25\%-át, a második a 22\%-át, a harmadik legnagyobb pedig az összes törés 16\%-át tartalmazza. Miután a repedéseknek már kb. egyharmada metszi egymást, a kimaradó törésekből összeállt csoportok mérete a paraméterek növekedésével egyre jobban elmarad a legnagyobb klaszter méretétől.

Fontos megjegyezni, hogy a 2. zónába eső összefüggő töréscsoportoknak nemcsak a mérete reagál érzékenyen az input paraméterek változására, hanem térbeli helyzetük is változó. Ez azt jelenti, hogy a repedéssürüség, -hosszúság eloszlás és -orientáció ismeretében nem tudjuk pontosan megmondani, hogy a kőzettest adott pontjában találunk-e összefüggő töréscsoportot, illetve ha igen, akkor annak mekkora a relatív mérete.

\section{III.1.2.3 A perkoláció paraméter-függése}

A kőzettestek repedéshálózatában kialakuló perkolációs klaszterek mérete az egyes geometriai repedésparaméterektől, esetünkben $E$-, $D$ - és $\alpha$-tól különböző mértékben függenek (3.5 ábra), melyre leginkább az előző fejezetben leírt 2. zóna szélességéből és orientációjából következtethetünk. 

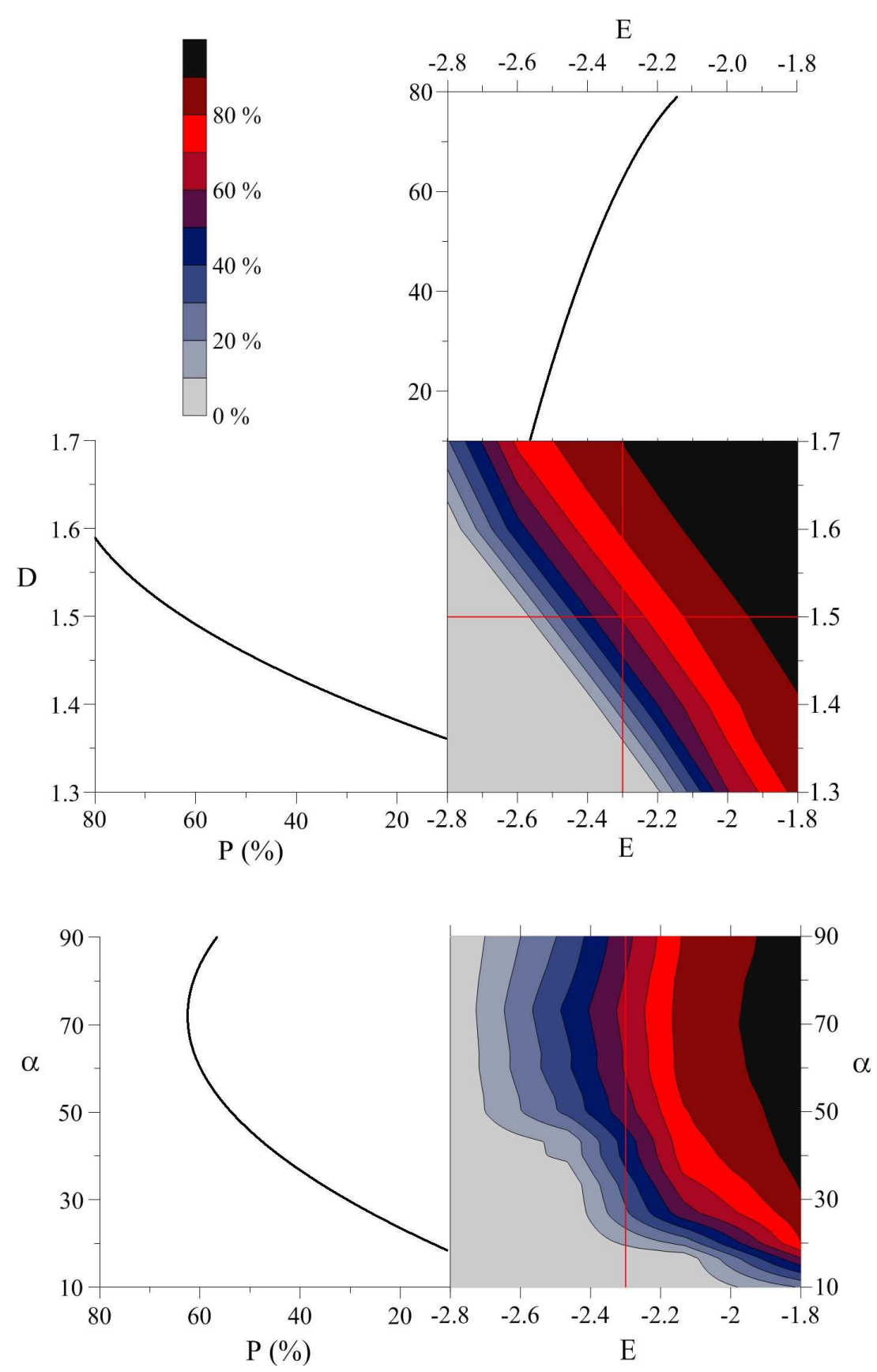

3.5 ábra A perkoláció érzékenysége az $E, D$ és $\alpha$ input paraméterek változására.

Minél meredekebben dől valamely zóna az adott paraméter tengelyéhez és minél keskenyebb, annál drasztikusabb módosulást idéz elő a legnagyobb perkolációs klaszter méretében az adott paraméter változása. Az $E-D$ változó síkon hasonlóan kis $E$ és $D$ növekedésre körülbelül egyformán nő az összefüggő repedések száma. Az E- $\alpha$ és $D$ - $\alpha$ síkokon pedig megfigyelhető, hogy kis $\alpha$-tól eltekintve - a relatív dőlés ugyan sokkal jobban befolyásolja a repedések összefüggőségét ebben a zónában, mint a másik kettőben (1. és 3. zóna), de közel sem olyan mértékben, mint $E$ és $D$. Másrészt a perkolációs klaszterek relatív mérete csökkenő tendenciát mutat $\alpha>\sim 70^{\circ}$ értékekre. A 
csökkenés mértéke annál nagyobb, minél kisebb az $E$ és $D$ paraméterek értéke. Meg kell jegyezni, hogy az áramlási tér anizotrópiáját tekintve nem a töréssürüség $(D)$ a meghatározó, sokkal inkább a repedések hosszúság- és nyitottság-eloszlása a fő befolyásoló tényező (Massonnat és tsai, 2002).

\section{III.1.2.4 Az E-D-a nomogramok alkalmazhatósága a Mórágyi gránit példáján}

Ismert $E$ - $D$ - $\alpha$ paraméterekkel jellemzett törésrendszer esetén az összefüggőség mértékének becslését nagyban segíti az $E-D, E-\alpha, D-\alpha$ nomogram sorozat (A.-C. melléklet). A módszer alkalmazhatóságának demonstrálására a Mórágyi-rög erdősmecskei felszíni kibúvásának gránit mintáit használtam fel.

A Mórágyi-rögöt variszkuszi korú gránitoid kőzetek építik fel (Klötzli és tsai, 2004), kiemelt jelentőségét az adja, hogy itt épült meg az első magyarországi kis- és közepesfokú radioaktív hulladéklerakó. Területe jelenleg részben felszínen van, részben vékony neogén-negyedidőszaki képződmények fedik. A posztmetamorf fejlődés során számos töréses deformációs esemény hatott a komplexum kőzeteire. Az egyedi törések uralkodó dőlésiránya az akusztikus lyukfaltelevíziós értékelés alapján ÉK- i, 70-80 dőlésszögek mellett. Ezentúl nagyszámú KÉK-NyDNy-i csapású, illetve meredek D-i dőlésü törések is megjelennek (Maros és tsai, 2003).

A gránit repedezett felszíne két különböző méretarányban lett digitalizálva; a mérések a teljes fal mentén, annak kb. $5 \cdot 10$ méteres, kinagyított részterületein, valamint $\mathrm{kb} .20 \cdot 20 \cdot 20 \mathrm{~cm}^{3}$ méretű kézipéldányokon történtek (Kaszai, 2003). Az erdősmecskei bánya gránitfalán közel 6500 db egyedi törés rögzítése történt meg digitális formában (M. Tóth, 2008). Ezek hosszúság eloszlása igen jó illeszkedéssel az elméletileg elvárt hatványfüggvény eloszlást mutatja. Kis és nagy méretek esetén ugyanakkor a tapasztalati eloszlásfüggvény lényegesen eltér a regressziós egyenestől, ami a szélső mérettartományokban a mérés bizonytalanságát mutatja. Míg kis mérettartományban az adott detektálási módszerre jellemző észlelési küszöb elérése miatt a törések darabszáma elmarad a várttól, a hosszú törések esetében a vizsgált térfogat nem bizonyult reprezentatívnak. Ehhez hasonló jellegű és paraméterü eloszlásfüggvények adódtak mind a gránit fal egyes részterületeinek nagyobb felbontású vizsgálatával ( $E=-2,46 \pm 0,2)$ (M. Tóth, 2008), mind a kézipéldány repedéseinek laboratóriumi, binokuláris mikroszkóp alatti elemzésével ( $E=-2,36$, Kaszai, 2003). A teljes falon végzett mérések alapján az $E$ paraméter értéke -2,48. A gránit fal 12 egyenlő méretű része alapján a törésközéppontok dimenziója $D=1,50 \pm 0,07$, a teljes falon számolt dimenzió érték $D=1,56$. A kézipéldányok esetében pedig, kis mérettartományra $D=1,45$ (Kaszai, 2003). Mindezek alátámasztják a vizsgált repedéshálózat skálainvarianciáját, fraktálszerü viselkedését.

$\mathrm{Az}$ általam teljes falon mért, a repedések nyomvonalából számított fraktál dimenzió $\mathrm{D}=$ 1,43-nak felel meg. A mórágyi gránitra jellemző repedéssürüség bizonyos gránitok jellemző 
fraktál dimenziójával hasonlóságot mutat, más képződmények adataitól pedig alapvetően eltér. A kapott érték alacsonyabb, mint a dél-angliai Dartmoor grániton végzett 1D és 2D vizsgálatok eredményei, melyek $\mathrm{D}=1,6$ és $\mathrm{D}=1,8$ között váltakoznak (Ehlen, 2000). A Velde és tsai (1991) által gránitoid kőzetekre meghatározott fraktál dimenzió intervallumba (1,24-1,51) ugyanakkor a mórágyi gránit is beleesik. Ehlen (1993) a montanai Pioneer hegység gránitjain szintén hasonló dimenzió értékeket állapított meg. Hozzávetőlegesen Barton és tsai (1991) gránitoid kőzeteken meghatározott dimenzió adatai csak kis mértékben térnek el az általam itt közölt eredményektől.

A mórágyi gránit repedésein mért geometriai paraméterek alapján a vizsgált kőzettest töréseinek 40-50\%-a kommunikál egymással. A perkolációs tulajdonságok - a 3.6 ábrán bemutatott nomogramok alapján - a mérés mérettartományától függetlenül hasonlóak.

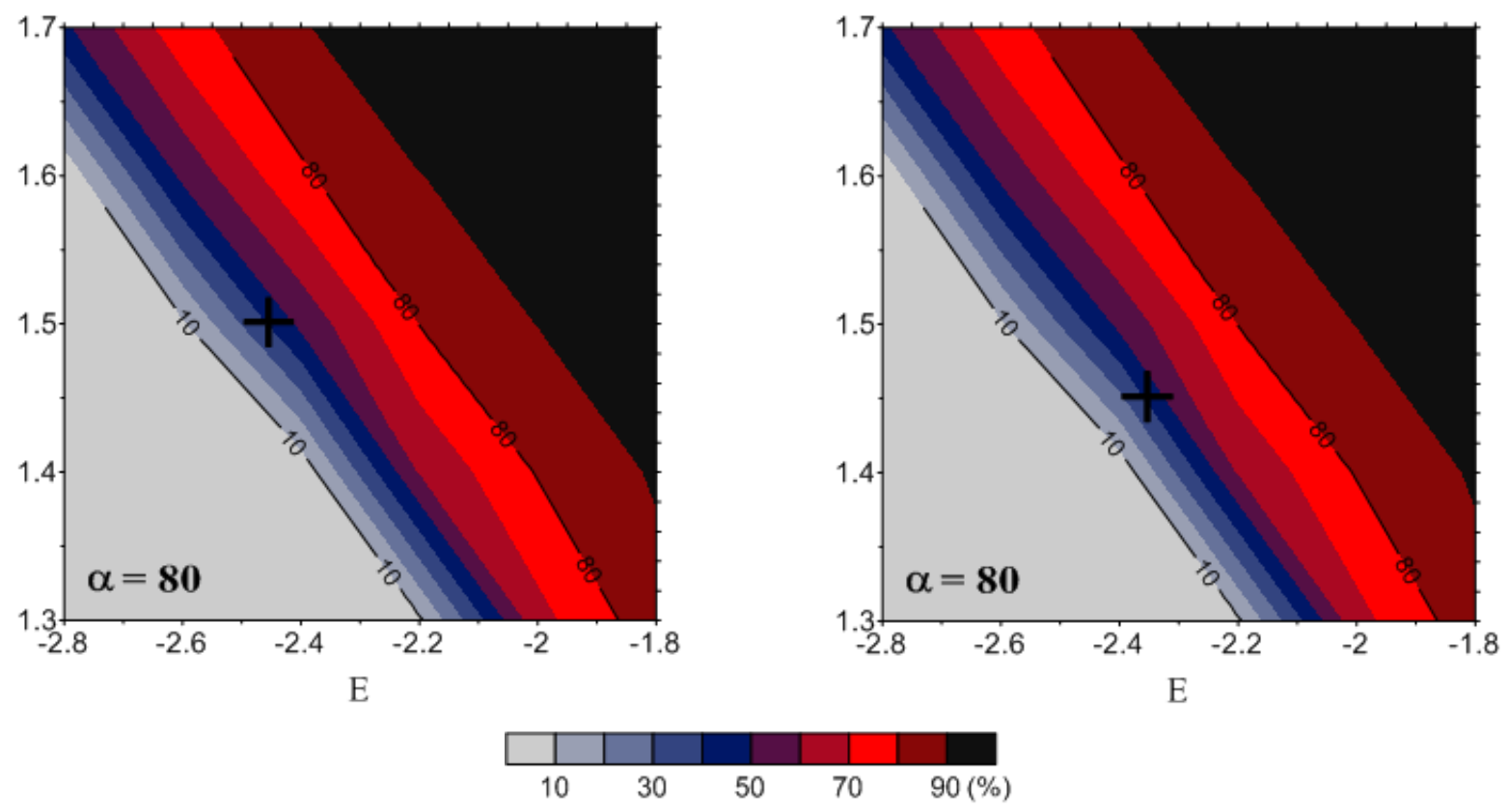

3.6 ábra A mórágyi gránit repedéshálózatának perkolációs jellemzői az $E-D$ - $\alpha$ nomogramok alkalmazásával, a gránitfalon (balra) és kézipéldányon (jobbra) mért paraméter értékek alapján.

Ugyanakkor az is jól látszik, hogy a repedéshálózat perkolációs tulajdonságai alapvetően eltérő eredményt mutatnak akár a fraktál dimenzió, akár az $E$ paraméter egytizedes, vagy annál kisebb mértékü különbségei esetén is. Ilyen kismértékü eltérés, valamint pontatlanság mind a mérettartományok közötti átjárás, mind a paraméterek közvetlen, illetve közvetett mérésénél szükségszerüen adódik. A kőzettesteken belül megjelenő litológiai változékonyság, a heterogenitás, továbbá olyan posztmagmás folyamatok, mint a mállás (Ehlen, 1999) további bizonytalanságot jelentenek a paraméterek pontos mérhetőségével szemben.

A perkolációs küszöb környékén nem becsülhető az adott kőzettest repedéshálózatának perkolációs viselkedése. Amennyiben valamely kőzetet reprezentáló pont az 1., illetve 3. zónába 
esik, abban az esetben a paraméter értékek meghatározásánál fellépő hibák ellenére is következtetni tudunk az összefüggőségi viszonyokra. Tehát, mivel a mórágyi gránit által reprezentált perkolációs tartomány nagyon érzékeny a paraméterek legkisebb változására is, az említett klaszter mérettől jelentősen eltérő eredmény is elképzelhető. 


\section{III.2. REV számítások}

A reprezentatív elemi térfogat (Representative Elementary Volume - REV) azt a legkisebb mérettartományt jelöli meg, amely felett bizonyos kőzettulajdonságok homogénnek tekinthetők (Bear, 1972). Ezen tulajdonságok alatt érthetünk akár hidraulikai, hőtranszport, mechanikai, vagy éppen geometriai paramétereket, azonban a különböző tulajdonságokra vonatkoztatott REV méretek nem feltétlenül azonosak egy adott kőzettest esetében. Általános esetben adott tulajdonság értéke a 3.7 ábrán szemléltetett módon változik a vizsgálódási skála függvényében, a REV pedig a változékonyság mértékének adott szint alá csökkenésével jelölhető ki.

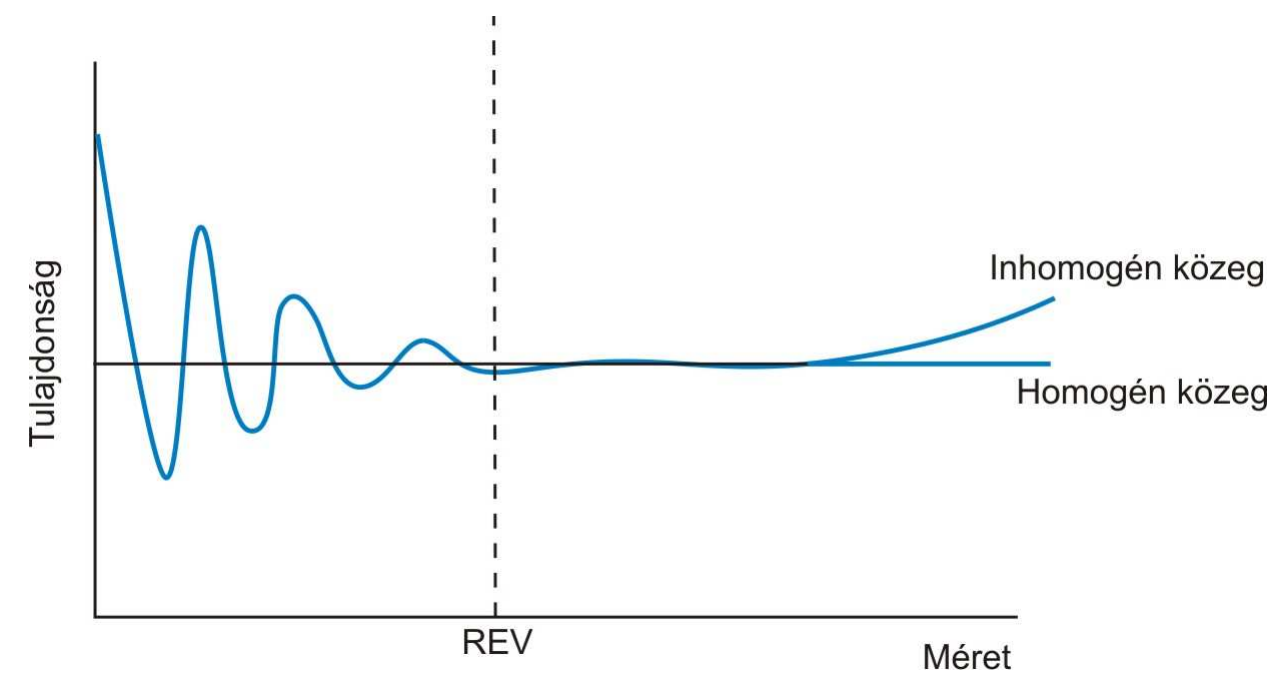

3.7 ábra A REV illusztrációja valamely kvantitatív tulajdonság változása tükrében - általános koncepció.

\section{III.2.1 $\underline{\text { A számítások alapja }}$}

A szimulált töréshálózat áramlásmodellezésre való alkalmazhatóság szempontjából - a perkoláció mellett - legfontosabb paraméterei a repedezett porozitás és belső permeabilitás tenzor (Oda, 1985). Valamely kőzettest számított porozitása ugyanakkor jelentős mértékben függ a választott térfogattól. A lépték fontos szerepét fejezi ki a REV fogalma, mely esetünkben azt a térfogatot jelenti, melynél nagyobb egységet választva már lényegében nem változik a számított, vagy mért porozitás. A RepSim program adott paraméterhalmazzal generált repedéshálózat porozitását a töréseket reprezentáló korongok és az őket tartalmazó rácselemek térfogatának arányából számítja, adott felbontás mellett a (6-8) képlet alapján. Így egy numerikus modellel végzett áramlási szimuláció során figyelembe veendő minimális cellaméret viszonylag egyszerüen kifejezhető. A továbbiakban a REV megadása az adott térfogatú kocka élhosszával fog történni a könnyebb átláthatóság miatt, a valódi méretet ennek köbre emelésével kapjuk. 
A REV vizsgálat olyan elméleti kőzettestekre készült, melyekben két, egymáshoz $60^{\circ}$-kal dőlő repedéscsoport van jelen, azaz $\alpha=60^{\circ}$. A számításokat a 3.1 ábrán bemutatott tulajdonságtest átlója mentén, az $E-D-\alpha\left\{\left(-2,8,1,3,60^{\circ}\right) ;\left(-2,6,1,4,60^{\circ}\right) ;\left(-2,4,1,5,60^{\circ}\right) ;\left(-2,2,1,6,60^{\circ}\right) ;(-2,0,1,7\right.$, $\left.\left.60^{\circ}\right) ;\left(-1,8,1,8,60^{\circ}\right)\right\}$ pontokban végeztem el. Az összes paraméterhármas esetén több mint száz azonosan valószínủ porozitás értéket generáltam az 1-50 m felbontású rácsháló lefedésével. Mivel a kapott porozitás értékek halmaza közel normális eloszlást mutat, a várható érték és a szórás jól jellemzi a statisztikai sokaságot. A 3.8 ábrán jól látszik, hogy a porozitások átlaga a felbontás növekedésével kis mértékben változik, míg a szórás monoton csökken bármely input paraméterhármas esetén.

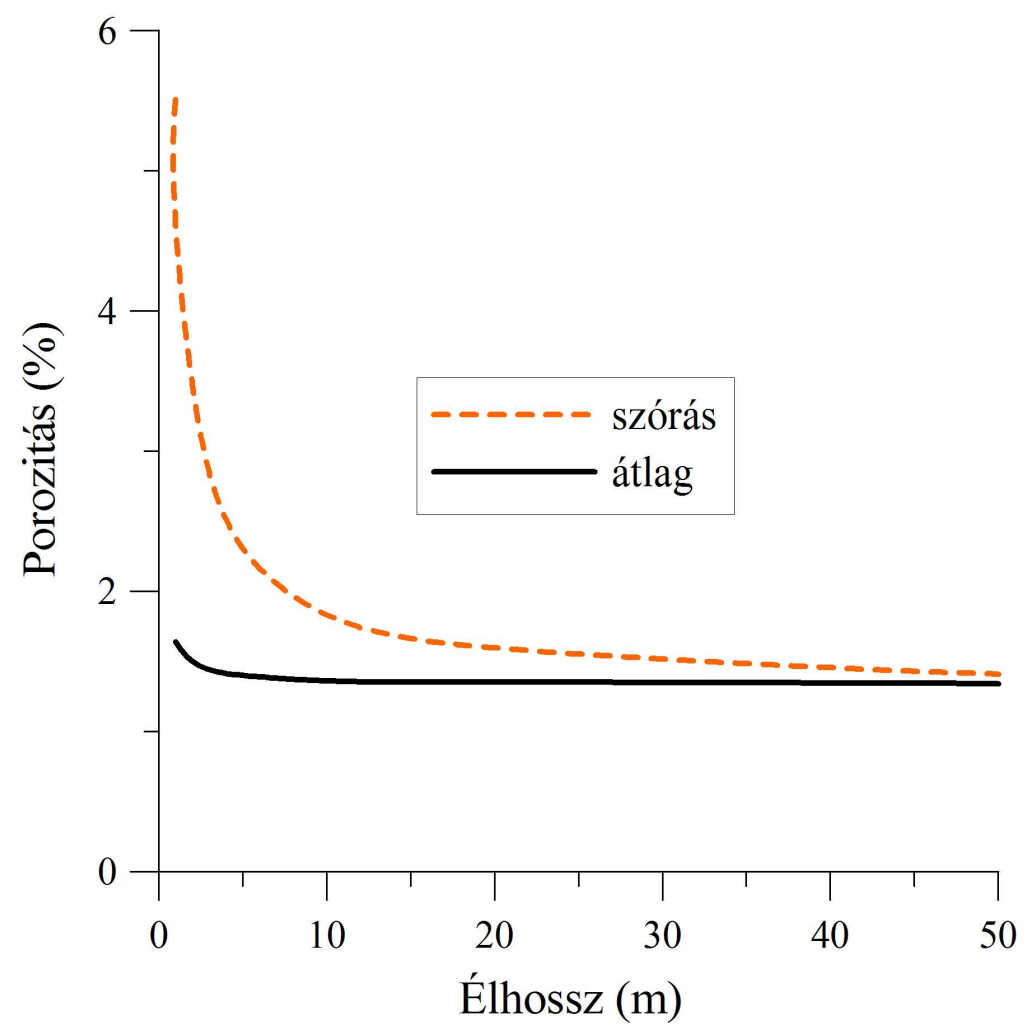

3.8 ábra A RepSim belső modulja által számított porozitás változása különböző felbontású rácshálók alkalmazása esetén.

Mivel ugyanakkor az átlag $(M)$ és a szórás $(\sigma)$ értékei a paraméterek függvényében széles határok között változnak, a különböző esetek összehasonlítására, valamint az egyes eseteken belül a REV kijelölésére célszerü a variációs tényezőt (५) használni:

$$
\varsigma=\frac{\sigma}{M}
$$




\section{III.2.2 Diszkusszió}

Mivel $M$ kis numerikus hibáktól eltekintve konstans, és $\sigma$ monoton csökkenő, így $\varsigma(s)$ monoton és konvergens függvény. Míg számos szerző (pl. Ahmed, 2002) szerint a variációs tényezö használata esetén 10\%, vagy annál kisebb vágásérték alkalmazandó, számos példa alapján esetünkben célszerübbnek tűnt ennél nagyobb, $\varsigma(s)=0.2$ értéket használni. A REV ekkor $s$ értékével lesz egyenlö.

A REV méretét tehát alapvetően a kőzet repedezettségének mértéke határozza meg, ami pedig az $E, D$ és $\alpha$ alapparaméterek állásától függ. A számítások azt bizonyítják, hogy a REV csökken a töréssürüség és -hosszúság növekedésével, míg a porozitás ezzel ellentétesen viselkedik (Vass és M. Tóth, 2007). A REV görbe monoton csökkenő, az $E$ és $D$ növekedésével egyre kisebb értékeket vesz fel. Olyan kőzetben tehát, ahol a repedések közül a hosszabbak dominálnak, és ezek sűrün töltik ki a teret, egy néhány tíz köbméteres térfogat vizsgálata már valósághű eredményt adhat a kőzet porozitásáról. Ellenben a rövidebb törésekkel ritkán átszőtt kőzet másodlagos porozitásának becsléséhez kb. 30-40 m (3.9 ábra), extrém esetekben még nagyobb élhosszúságú egységet szükséges választani.

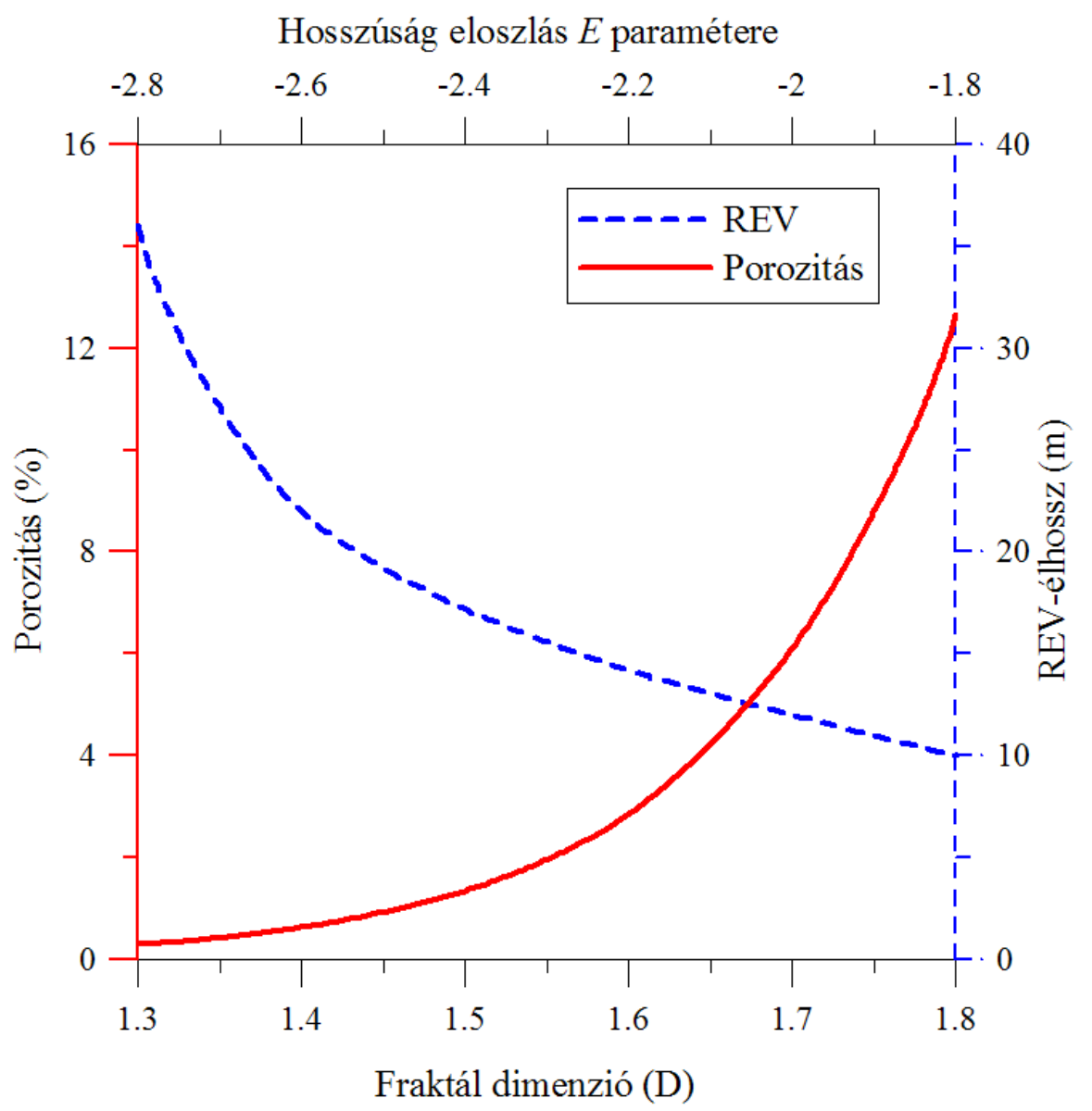

3.9 ábra A repedéssürüség és repedéshosszúság eloszlás hatása a porozitás és REV alakulására. 
Az ábrán jól látszik, hogy míg alacsony paraméter-értékek $\left(-2,8,1,3,60^{\circ}\right)$ esetén a REV élhossza meghaladja a $30 \mathrm{~m}$-t, addig a maximumnál $\left(-1,8,1,8,60^{\circ}\right)$ nagysága mindössze 10 métert tesz ki. A szóban forgó mérettartomány a skálának pontosan az a része, amely fúrómag léptékben már nem, geofizikai módszerekkel pedig még nehezen vizsgálható. Ez tehát megerősíti a repedéshálózat szimulációjára irányuló valós igényt, valamint a hidrodinamikai paraméterek törésmodellből történő származtatásának szükségességét.

Egy adott kőzettest másodlagos porozitását, azaz a benne jelen lévő repedéshálózat által kitöltött térfogat nagyságát alapvetően a törések száma, hosszúsága és nyitottsága határozza meg. Amíg a porozitás egyértelműen nő a hosszúság és nyitottság növekedésével, addig az adott paraméterhármassal generált töréshálózatra jellemző REV független lesz a nyitottság $(A)$ megválasztásától (M. Tóth és Vass, 2011), mivel:

$$
\frac{\sigma(A \cdot L)}{M(A \cdot L)}=\frac{\sqrt{\frac{n \sum_{i=1}^{n}\left(A \cdot L_{i}\right)^{2}-\left(\sum_{i=1}^{n} A \cdot L_{i}\right)^{2}}{n(n-1)}}}{\frac{\sum_{i=1}^{n}\left(A \cdot L_{i}\right)}{n}}
$$

ahol $L_{i}$ az $i$-dik repedés hossza, $n$ a repedések száma, ami továbbá egyenlő

$$
\frac{A^{2} \cdot\left[n^{2} \sum_{i=1}^{n} L_{i}^{2}-n \cdot\left(\sum_{i=1}^{n} L_{i}\right)^{2}\right]}{(n-1) \cdot A^{2} \cdot\left(\sum_{i=1}^{n} L_{i}\right)^{2}}
$$

végül

$$
\frac{\sqrt{\frac{n \sum_{i=1}^{n} L_{i}^{2}-\left(\sum_{i=1}^{n} L_{i}\right)^{2}}{n(n-1)}}}{\frac{\sum_{i=1}^{n} L_{i}}{n}}=\frac{\sigma}{M}
$$

Az tehát, hogy a szimuláció során milyen input paraméterekkel számoltuk a hosszúságból a nyitottságot, nem befolyásolja a REV méretét. Ez igen lényeges szempont, hiszen a repedéseken végzett nyitottság mérések általában jelentős hibával terheltek. 


\section{Aljzati kristályos magaslatok hidrodinamikai és hőtranszport folyamatainak komplex tanulmányozása}

\section{IV.1. Földtan - vízföldtan - geotermikus viszonyok}

\section{IV.1.1 Földtani tulajdonságok}

\section{IV.1.1.1 Pre-kainozóos aljzat}

A Tiszai nagyszerkezeti egység délkeleti részén, a Villány-Bihari és Békés-Kodru szerkezeti egységek területén a kristályos aljzat alapvetően paleozóos magmás és metamorf képződményekből épül fel. A kristályos alaphegységre helyenként mezozóos karbonátok is települnek (pl. Kiskunhalas, Tázlár, stb.) élesen elhatárolódva a harmadidőszaki medencebeli kőzetektől. A morfológiára az intenzív tektonika okozta erős tagoltság jellemző, felszíne 300 m-től egészen a 6000 m alatti mélységtartományig nyomon követhető.

A Békés-Kodru öv takarófrontjától északra húzódó Villány-Bihari szerkezeti egység északon a Szolnoki Flis övre és a Mecseki szerkezeti öv mezozóos rétegösszletére tolódott rá. Nyugati részét a Jászszentlászlói metamorfit összlet, keleti részét a Körösi metamorfit összlet alkotja. A két terület kristályos aljzata lényegében egységes felépítésű, dominánsan amfibolit fáciesű gneisz-csillámpalából áll, amfibolit-amfibolitgneisz betelepülésekkel (Fülöp, 1994). A Békési-medence északi oldalának aljzatában alapvetően három, eltérő metamorf fejlődéstörténettel rendelkező kristályos blokk követi egymást, ahol a legmélyebb szerkezeti helyzetben található ortogneisz fölött szillimanitos biotitgneisz és amfibolos biotitgneisz következik, posztmetamorf szerkezeti határok mentén (M. Tóth és Zachar, 2006).

A Békés-Kodru öv az Alföld D-DK-i, tektonikusan erősen tagolt takarós szerkezeti egységét képezi. További részegységeiként nevezhetők meg a következő, esetenként földtani felépítésükben is eltérő területek: Kelebia-Üllés (kétcsillámú pala, helyenként amfibolittal és gneisszel), AlgyőFerencszállás (kétcsillámú gneisz, elvétve amfibolit; csillámpala), Pusztaföldvár-Battonya (csillámpala, amfibolit, gránit) és Sarkadkeresztúr (csillámpala, gneisz, amfibolit).

A komplexumon belül az említett két szerkezeti öv területén elhelyezkedő aljzati magaslatokra fókuszáltam (4.1 ábra), melyek, bár szerkezetfejlődésük és metamorf evolúciójuk részletei alapján számottevően eltérnek egymástól, alapvető litológiai felépítésük hasonlónak tekinthető. 


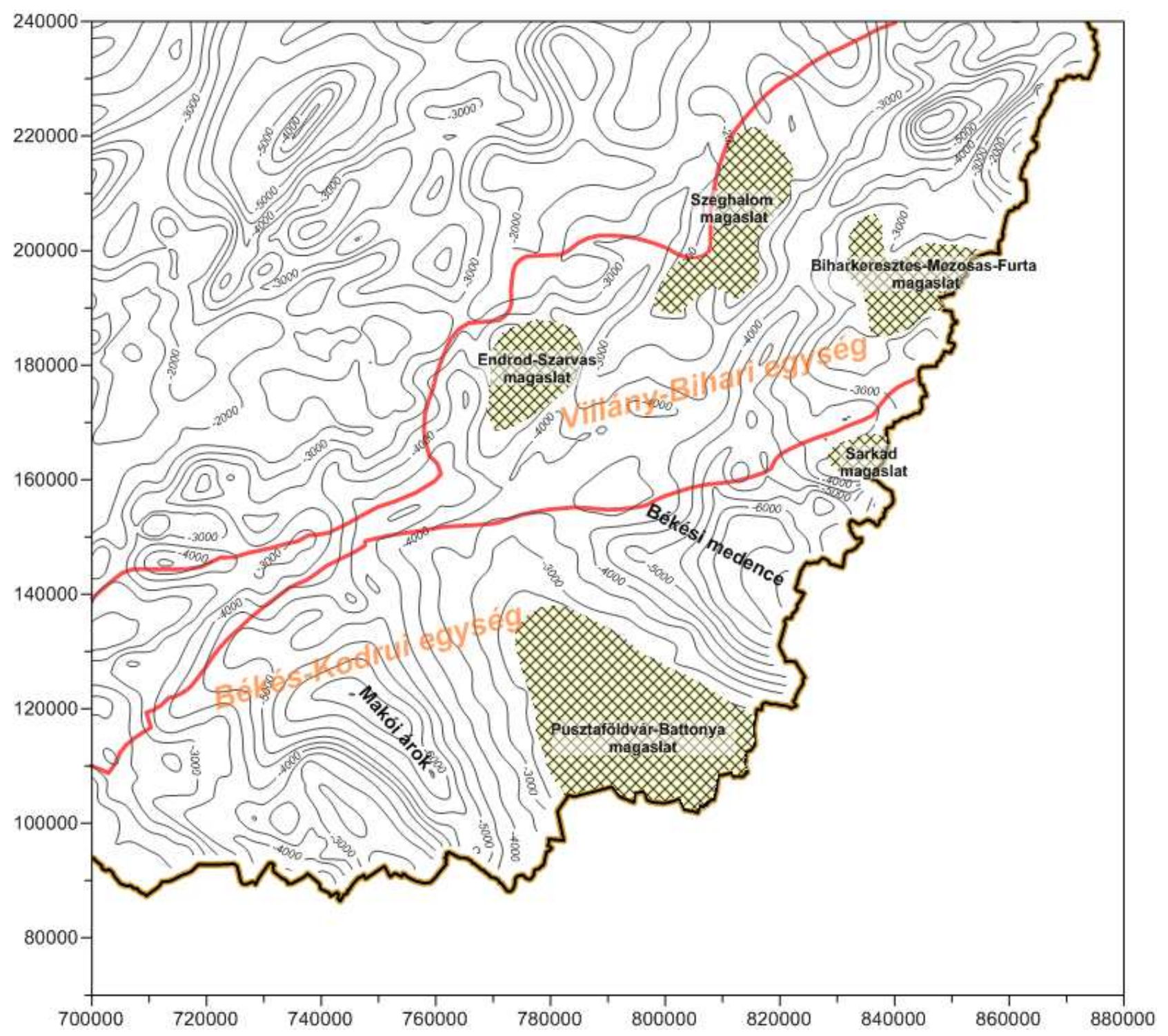

4.1 ábra A preneogén aljzat morfológiája a DK-Alföldön a kiemelt helyzetü kristályos hátak és mély medencék elhelyezkedésével (Haas és tsai, 2010 nyomán).

Az északi részen húzódó Endrőd-Szarvas, Szeghalom és Mezősas-Furta magaslatok központi zónájában a szillimanitos biotitgneisz és gránátos amfibolit dominál (M. Tóth és tsai, 2000). A Békés-Kodru egység ÉK-i részén, Sarkad és Sarkadkeresztúr vonalában húzódó aljzati kiemelkedés nagy részét csakugyan gneisz (kétföldpátos augnegneisz és kevés paragneisz), amfibolit és csillámpala építi fel (Lelkesné Felvári, 2007). A Pusztaföldvár-Battonya tengelyében húzódó metamorf hát déli részén inkább nagy kiterjedésủ migmatit- és gránittömegek dominálnak, de keleten itt is megjelenik a gránitosodott képződmények közé ékelődött gneisz és amfibolit.

Villány-Bihari és Békés-Kodru szerkezeti egységek területére eső aljzati hátak közül a Szeghalom dóm az egyik legjobban megkutatott, így a kőzettani felépítést tekintve ezt választottam mintapéldának. Szeghalomnál az aljzat alapvetően közepes és nagyfokú metamorf 
képződményekből áll, melyek döntően amfibolit és eltérő fejlődésü gneisz típusok, alárendelten csillámpala. Az eltérő metamorf fejlődésű kőzetblokkok határát posztmetamorf nyírási zónák jelölik ki (M. Tóth és tsai., 2008); az aljzati kiemelkedést számos, közel ÉD-i csapású normálvető tagolja kisebb egységekre.

\section{IV.1.1.2 Neogén és fiatalabb medencekitöltö üledékek}

Az Alföld alatti komplex üledékes medencében a tengeri, delta, tavi, fluviális és eolikus törmelékes üledékek rétegek több száz - több ezer méter vastagságban rakódtak rá a variszkuszi kristályos aljzatra. A neogén üledékképződés riftesedéssel kezdődött (kora miocén), melyet főként agyag és konglomerátum képződésével társuló gyors süllyedés követett. A középső-miocénben vastag tengeri eredetü mészkő, turbidit és márga rétegeket hátrahagyva folytatódik az extenzió és riftesedés. Ezt követően az alsó-pannóniai eleji transzgresszió hatására a kiemeltebb helyzetủ aljzati szárazulatok is víz alá kerülnek, ami jelentős laterális fáciesbeli változásokat idéz elő. A szigetek körül lerakódó parti, partközeli konglomerátumot és durva szemcsés homokkövet helyenként már néhány kilométeres távolságban aleurolit, márga illetve mészkő követi.

Az alsó-pannóniai formációk legidősebb tagja a Békési Konglomerátum Formáció, mely az alaphegységből származó, helyi eredetü vagy kis távolságból szállított, uralkodóan metamorf és mezozóos kőzettörmelékből álló, abráziós partszegélyi konglomerátum, homokkő, ritkábban breccsa anyagú bázisképződmény. Elterjedése a pannóniai alsó részében meglévő szigetek környezetére korlátozódik, vastagsága nem haladja meg a néhány 100 m-t (Császár, 1997).

Az Endrődi Formáció rendkívül változatos vízmélységviszonyok között kialakult nyíltvízi, hemipelágikus képződmény, összesített vastagsága átlagosan 100-200 m, maximálisan 700 m. A rétegsor általában mészmárgával, márgával indul (Tótkomlósi Mészmárga Tagozat), felfelé fokozatosan mélyvízi (hemipelágikus) agyagmárgába megy át (Nagykörüi Agyagmárga Tagozat). A mészmárga több litofáciest képvisel: kiemelt hátak fölött, sekély vízben világosszürke, sárgásszürke, a mélyzónákban sötétszürke, helyenként feketésszürke. Meredek aljzatmorfológia esetén elszórtan az aljzatból származó kaviccsal (Dorozsmai Márga Tagozat) együtt jelenik meg. A formáció felsőbb részén a disztális turbiditként vékony aleurolit-homokkő csíkok jelennek meg, fokozatos átmenetként a Szolnoki Formáció felé (Vásárhelyi Márga Tagozat). Kora túlnyomó részt alsó-pannóniai, az Alföld DK-i részén egészen a felső-pannóniai emeletig terjed (Császár, 1997).

A Szolnoki Homokkő Formáció elsősorban mélyvízi környezetben keletkezett, turbidit eredetü finomszemcsés homokkő, aleurolit és agyagmárga-márga rétegek váltakozásából áll, melyek üledékfolytonosan települnek az Endrődi formációra. Vastagsága nagyon változó, a 
mélymedencékben meghaladja az 1000 m-t, a medenceperemek irányában kiékelődik (Császár, 1997).

Az Alföldön az alsó-pannóniai emelet végét elsősorban víz alatti lejtő környezetben (delta lejtő és medence lejtő) lerakódott sötétszürke agyagmárgás képződmények, az Algyői Formáció képviseli. A rétegsorban helyenként torkolati zátony, víz alatti mederkitöltés és gravitációs eredetü aleurolit és homokkő testek települnek területenként változó vastagsággal és gyakorisággal. A formáció vertikális kiterjedése 100-900 m között alakul (Császár, 1997). Erre települnek a delta front és delta síkság felfelé egyre durvább szemcsés üledékei, valamint alluviális homok és aleurolit (Újfalui és Zagyva Formáció).

A negyedidőszakban az Alföld egyes területei tovább süllyedtek, minek következtében helyenként sok 100 m-t is elérő finom-durva szemcsés, konszolidálatlan rétegek rakódtak le.

\section{IV.1.2 Vizföldtani jellemzök}

A Pannon-medence hidrosztratigráfiailag 2 nagy egységre osztható: preneogén rezervoár, illetve a fiatalabb vízadó rétegek. Utóbbi a litológia és permeabilitás változása alapján további 5 részegységre tagolható, ezek képviselői tételesen a pre-pannóniai vízadó, Endrőd víztartó, Szolnok vízadó, Algyő víztartó és a Nagyalföld vízadó (Tóth és Almási, 2001). A negyedidőszaki üledékes kőzetek, sok helyen kiegészülve a pannóniai hévíztartóval, hidrogeológiailag egységes áramlási rendszert alkotnak, melynek fő mozgatóereje a felszín domborzatából eredő gravitáció. Ez a regionálisan nyitott áramtér alapvetően a felszínen beszivárgó csapadékból kapja az utánpótlást, melyet a regionális egységeken belül müködő további kisebb, intermedier és lokális rendszerek szállítanak tovább.

A nyomásviszonyok ebben a zónában a hidrosztatikus vagy ahhoz közeli állapotokat tükrözik. A lefelé csökkenő potenciálú területek jelentik a rendszer fő tápterületeit, a legfontosabbak az Alföldön a Duna-Tisza közi hátság és a Nyírség. Az itt beszivárgó víz a lefelé növekvő potenciálú megcsapolási területeken, az Alföld mélyebb részein és a folyóvölgyekben, különösen a Tisza-völgy irányában jön a felszínre. Az alsó-pannóniai finomszemcsés üledékek ezzel szemben általában rossz vízvezetők, innen származó jelentősebb vízkivétel, vízfelhasználás nem jellemző, alsó részükön szigetelő márgás, agyagos rétegek korlátozzák a mélyebb rendszerekkel való kapcsolatot.

A preneogén rezervoárban tározódó mélységi vizek az előzőtől alapvetően elszigetelt áramlási rendszert alkotnak. A szivárgás itt elsősorban a repedéshálózat egyes elemeihez kötött, mivel a kristályos kőzetek mátrix porozitása szinte elhanyagolható. E vizek kémiai összetételére a 
magas, 10-20 g/l közötti sótartalom jellemző (MOL adatbázis, Varsányi és tsai, 1999), de nem ritkán találkozhatunk 30 g/l-t is meghaladó értékekkel (Zilahi-Sebess és Gyuricza, 2012a, 2012b).

A Pannon-medence aljzatának nyomásviszonyai az Alföld területén igen sajátos képet mutatnak. Míg a medencekitöltő üledékek a felső-pannóniai rétegek alsó határáig hidrodinamikailag nyitott rendszert alkotnak, ahol a potenciál a hidrosztatikus, vagy közel hidrosztatikus állapotoknak megfelelően alakul, addig az aljzati kristályos komplexum többnyire elszigetelt, zárt hidrogeológiai egységét a hidrosztatikusnál lényegesen nagyobb, helyenként akár 3-3,5-szer is nagyobb túlnyomás (30-35 MPa/km) jellemzi (Almási, 2001). A túlnyomásban felfedezhető eloszlásbeli különbségeket elsősorban a litológiai változatosság, porozitás és permeabilitás változása, valamint a felelős geológiai folyamatok térbeli és időbeli eloszlása okozza.

Adott földtani rezsim esetén a túlnyomást okozni képes természetes mechanizmusok négy csoportra oszthatók (Osborne és Swarbrick, 1997):

\section{a) kompresszió}

A kompressziós folyamatok alatt érthetünk egyrészt kompakciót, másrészt laterális tektonikus kompressziót. Az első esetben a folyamatos üledékfelhalmozódás és vele egyidejü, gyors medencesüllyedés hatására nő meg a vertikális főfeszültség, ami a kőzetanyag kompakcióját, s egyben a pórustér csökkenését és a tárolt fluidum kipréselődését eredményezi. Amennyiben a réteg alacsony permeabilitással rendelkezik, úgy jelentős túlnyomás alakulhat ki, ahol a lerakódott üledék súlyából származó nyomás nagy részét tulajdonképpen a pórustérből kiszorított fluidum viseli.

A második esetben a horizontális feszültségtérben bekövetkező változások hatására (pontosabban, amikor a horizontális föfeszültség nagysága meghaladja a vertikálisét) alakul ki túlnyomás a tektonikailag aktív területeken.

\section{b) vízrekesztő fedőképződmények}

Az előző pontban részletezett horizontális stressz hatására kialakuló túlnyomás akkor tud igazán sokáig, geológiai időléptékben is fennmaradni egy adott mélységszintben, ha felette vastag vízrekesztő üledékes réteg van jelen. Többek között ilyen szerepet tölt be a Tiszai egységben regionálisan elterjedt Endrődi formáció, mely bizonyos geológiai helyzetekben korlátozza a mélységi fluidumok feláramlását, s egyben a nyomás kiegyenlítődését (Almási, 2001).

A vízrekesztő agyag és márga rétegekben, ahol a szivárgási tényező extrém alacsony értékeket is felvehet, sok esetben egyébként is tapasztalható a nyomásgradiens lokális megnövekedése. 


\section{c) a fluidum térfogatnövekedése}

A fluidum térfogatnövekedése, avagy a pórustér csökkenése ugyancsak túlnyomásos zónák kialakulásához vezethet. Ennek egyik oka lehet bizonyos ásványok diagenezis során bekövetkező vízvesztése, mint például a szmektit dehidrációja, mely a permeabilitás romlását idézi elő. A kerogén termikus érése során keletkező folyékony és gáznemü szénhidrogének szintén a fluidum térfogatbeli növekedését okozzák, mely lokálisan túlnyomáshoz vezethet a pórustér növekedési ütemének meghaladása esetén.

d) fluidum-mozgás és sủrüségkülönbség által gerjesztett folyamatok

A hidraulikus gradiens, felhajtóerő és ozmózis által előidézett sürüségkülönbségen (sótartalom) alapuló folyamatok és fluidum-áramlás szintén túlnyomásos zónák kialakulásához vezethet, ám ezek, ha bizonyos esetekben jelentős mértéküek is lehetnek, a Pannon-medencében csak lokálisan vannak jelen (Almási, 2001).

Az üledékes medencék egy részére jellemző mélységi túlnyomásos zónák jelenléte kompakció által indukált pórusnyomás növekedés, ahol a nyomás-kompenzációt vastag finomszemcsés réteg gátolja (Gordon és Flemings, 1998) - megfigyelhető Dél-Texas államban a Mexikói-öböl partvidéke közelében is, ahol a hidrosztatikust több mint 100\%-kal meghaladó nyomásértékeket regisztráltak a 3400 m alatti tartományban (Engelder és Leftwich, 1997).

Ezzel szemben a Dél-ausztráliai Cooper Basin mélységi kőzeteinek túlnyomásos jellegét nem a szedimentáció okozza, hanem valószínüleg a felső-kréta végétől megnövekvő horizontális feszültségek és mélységi gázképződés együttesen játszhattak szerepet (Van Ruth és tsai, 2003).

Az Alföldön az aljzati túlnyomásos régiók kialakulásában a jelenlegi ismereteink szerint a fent részletezett mechanizmusok közül elsősorban a Pannon-medencében uralkodó, miocén végétől jelen lévő regionális kompresszió a felelős (Van Balen és Cloetingh, 1994; Tóth és Almási, 1998; Almási, 2001), mely ott tud igazán nagy hatást kifejteni, ahol viszonylag nagy vastagságú, impermeábilis fedőkőzetek is jelen vannak.

\section{IV.1.3 Geotermikus viszonyok}

Az Alföld térségében lezajló mélységi geotermikus folyamatok megismeréséhez elsősorban a földi hőáram eloszlásának tanulmányozása vezethet. A Pannon-medence földi hőáramsürüségének térképét Dövényi és társai 1983-ban publikálták (4.2 ábra). A számítások alapját jelentő adatbázis több mint 4600 olyan kutat tartalmaz, melyek hőmérsékleti szelvénnyel rendelkeznek és ismert 
litológiai leírás tartozik hozzájuk, esetleg történt magminta vétel, ami lehetővé tette a hővezetőképesség mérését.

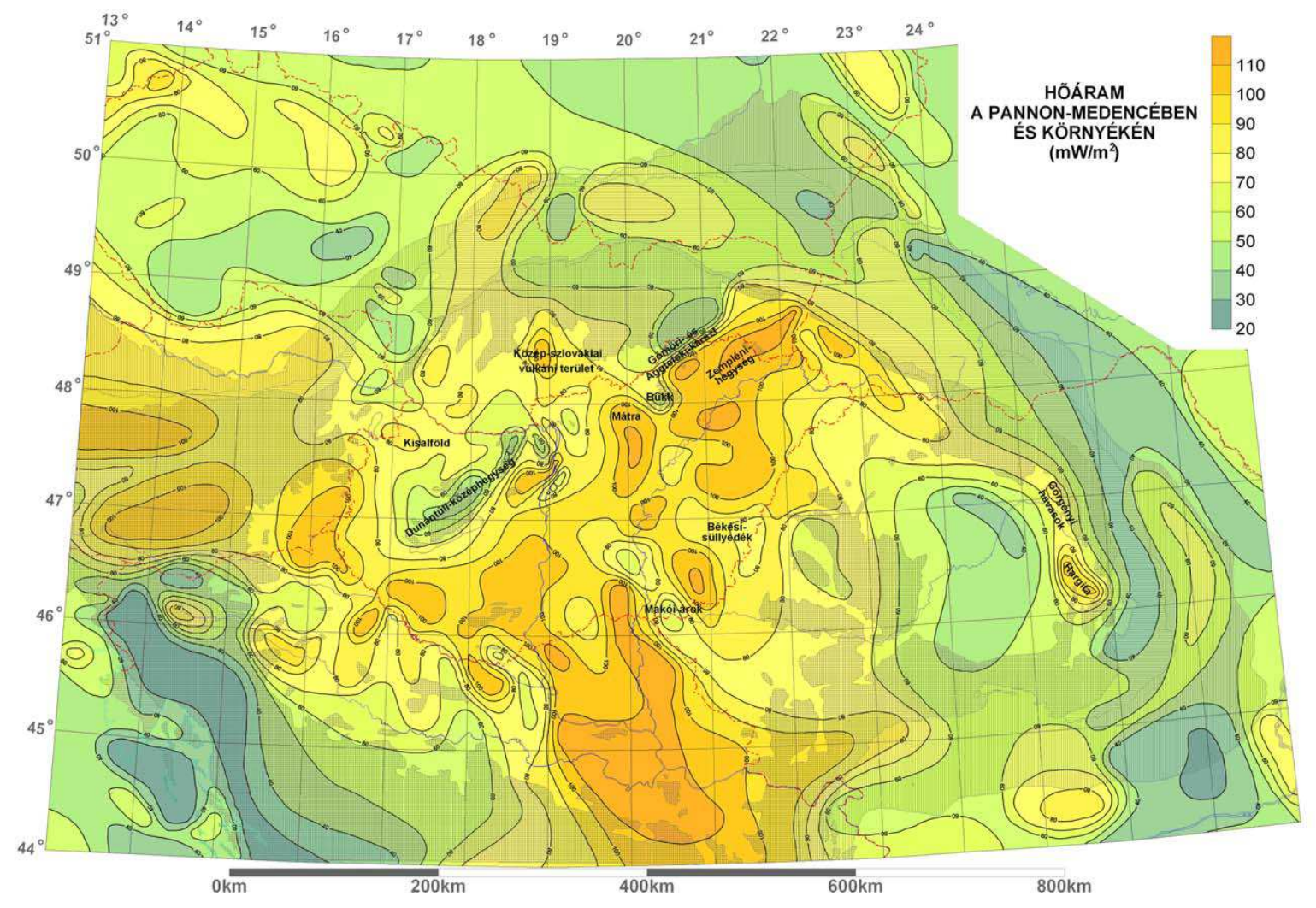

4.2 ábra Az Alföldön jellemző felszíni hőáramsürüség (kivágat, Dövényi és tsai, 1983 alapján).

A hőáramsűrüség eloszlása jól követi az aljzat morfológiáját: a kristályos hátak felett, ahol viszonylag vékony a szigetelő üledékes réteg, az értékek meghaladják a 90-100 mW/m²-t; ezzel szemben a mélyebb medencék, árkok központi részén a $80 \mathrm{~mW} / \mathrm{m}^{2}$ alatti értékek sem ritkák.

A Pannon-medence alatti magas hőáram a harmadidőszaki lemeztektonikai mozgásokig vezethető vissza. A külső-kárpáti óceáni kéreg Tiszai egység alá történő szubdukciója a Kárpátok hegységrendszerétől nyugatra ív-mögötti régiót hozott létre (Royden, 1988; Horváth, 1993). A területre jellemző extenziós feszültségtér kialakulása a középső-miocénre tehető, melyet közvetlenül a litoszféra elvékonyodása követett. A kivékonyodott és lesüllyedt kéregre ezután nagy vastagságban változatos üledékek települtek, ahol a medence felfütődésének mértékét a medence süllyedése és a lerakódó kőzetanyag együttesen alakították.

Ezen okokra vezethető vissza, hogy a geotermikus gradiens Magyarországon viszonylag magas, átlagos értéke $\sim 45^{\circ} \mathrm{C} / \mathrm{km}$, s ennek köszönhetően a viszonylag sekély aljzati tárolók egy része már a magas entalpiájú (Muffler és Cataldi, 1978) geotermikus rezervoárok körébe sorolható (4.3 ábra). 


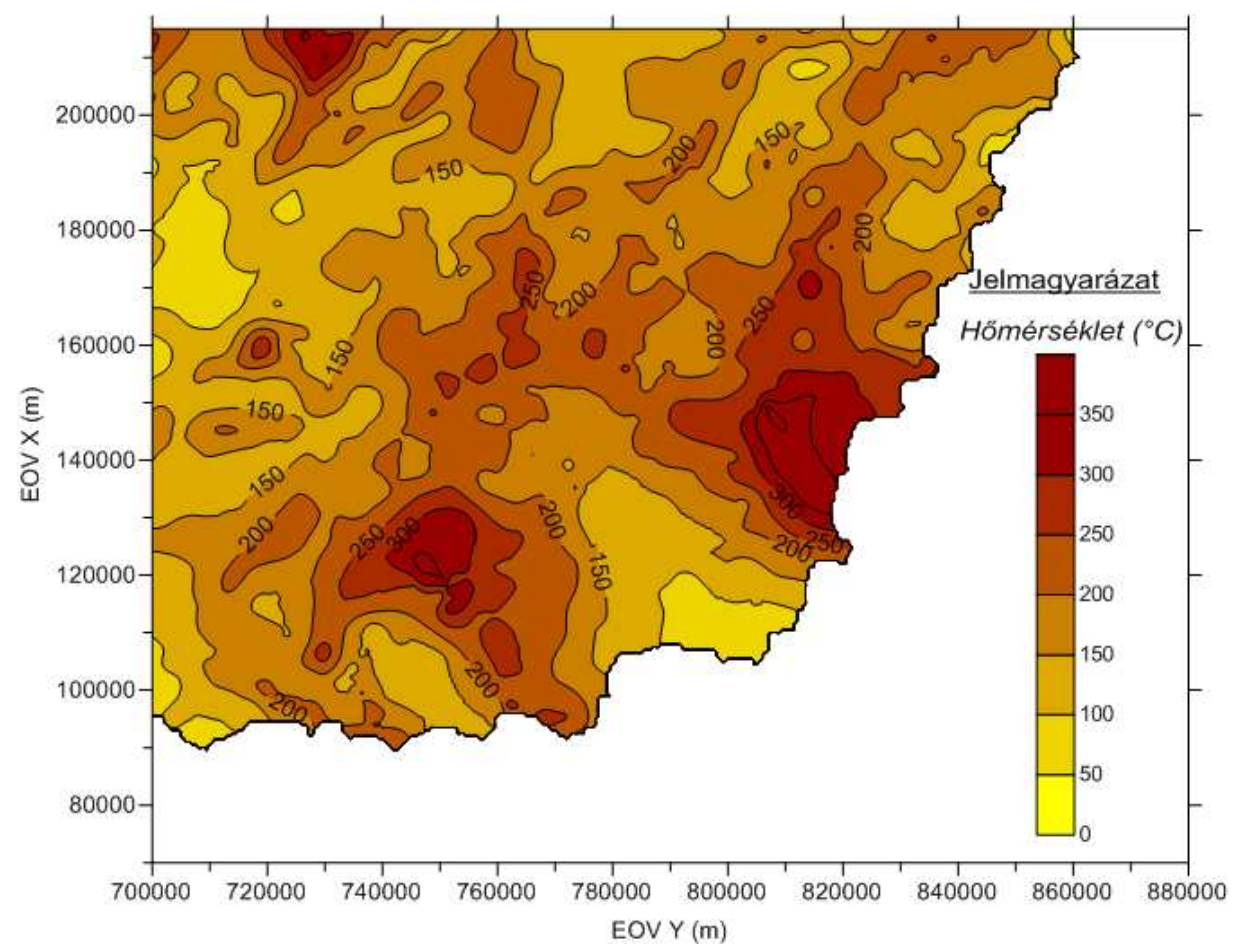

4.3 ábra Várható hőmérséklet a preneogén aljzat felszínén, az Alföld területén (Pethő és Vass, 2011). 


\section{IV.2. $\quad$ Alkalmazott módszerek}

Az Alföld kristályos aljzatának kiemelt helyzetü blokkjaiban, illetve az aljzat és az üledékes fedő képződmények között lejátszódó hidrodinamikai és hőtranszport folyamatok vizsgálata a hagyományos módszerekkel igen nehézkes, ugyanis a porózus közeg áramlási viszonyainak numerikus modellezésére alkalmas szoftver rendszerek nem képesek megfelelöen kezelni a repedezett tárolókra jellemző szerkezeti elemeket. Ennek megoldását olyan összetett repedéshálózat vizsgálati módszer és modellezési eljárás alapján végeztem, ami egyúttal eszközt nyújt azokra a problémákra, melyek elsősorban kristályos kőzettestek által felépített rezervoárok fluidum-áramlási sajátosságaira kívánnak megoldást találni.

A módszer lényege, hogy a numerikus modell struktúrájába szisztematikusan beépítjük a repedezett kőzettestről nyert információkat (4.4 ábra). Először a repedezett kőzettest egyedi töréseinek és töréshálózatának legfontosabb paramétereit (repedéssürüség, töréshosszúság-, nyitottság eloszlás, orientáció) adjuk be egy alkalmas DFN szimulátorba, esetünkben a RepSim-be. A sztochasztikusan generált töréshálózatokon ezután további hidrodinamikai paramétereket számítunk (porozitást és permeabilitás), ezen kívül REV és perkolációs vizsgálatot készítünk, ahogyan azt a III. fejezetben láttuk. Ezek az információk végül egy ekvivalens kontinuum modellben (Modflow ill. Feflow) fognak szerepelni a hidrodinamikai és hőtranszport számítások bemeneti paramétereiként. A folyamat egészét tekintve valójában egy hibrid típusú modellezés valósul meg a diszkrét repedések és homogenizált áramlási tér összekapcsolásával, ahol a számszerüsítés a következőképpen zajlik:

- DFN szimulátorral számolt permeabilitás tenzor konvertálása horizontális és vertikális szivárgási tényezőkké (IV.3.4.3 fejezet);

- REV vizsgálat elvégzése a DFN szimulátorral számolt porozitás alapján, REV megfeleltetése, mint homogén cellaméret (IV.3.2 fejezet);

- perkolációs vizsgálat elvégzése a DFN szimulátor használatával, majd az összefüggő és nem összefüggő repedéscsoportokból effektív porozitás becslése (IV.3.4.2 fejezet).

Ezeknek az egységesített repedésparamétereknek, valamint a porózus kőzetek paramétereinek importálása már a szokásos módon történik, ennek részleteire a következő fejezetben térek ki. 


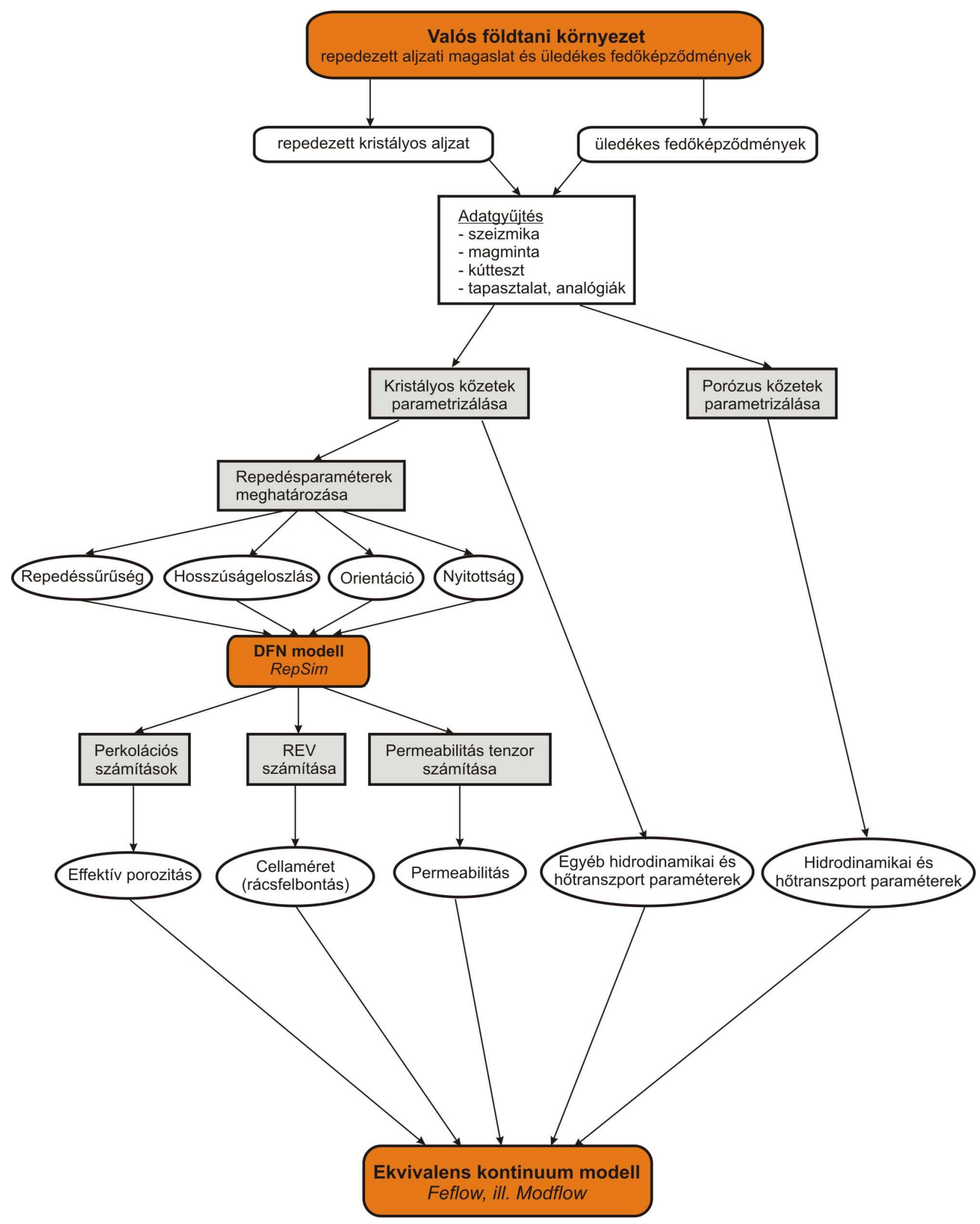

4.4 ábra A komplex repedezett-porózus rendszer hidrodinamikai és hőtranszport modellezési sémája.

A magmás-metamorf komplexum repedéshálózatának modellezése a RepSim 4.1 DFN algoritmust használó szimulátorával készült. A hidrodinamikai modell elkészítéséhez, valamint az 
áramlás törvényszerüségeinek meghatározásához a Processing Modflow Pro szoftver környezet 5.3.0 (Copyright (C) 1991-2001 W.-H. Chiang \& W. Kinzelbach) verzióját, illetve a Feflow 6.0 (Copyright (C) 1979-2010 DHI-WASY GmbH) szimulátort használtam. Az áramlási egyenleteket a Modflow-96 ill. Modflow-2000 programok által felkínált algoritmusok segítségével, valamint a Feflow beépített, iteratív egyenletrendszer megoldóival számítottam. Az elérési idők a PMPATH részecske követő modul 6.1.4 (Copyright (C) 1999-2004 W.-H. Chiang \& W. Kinzelbach) verzióját, illetve a Feflow rendszer integrált részecske nyomvonal elemzőjét alkalmaztam. A numerikus számításoknak így a két leggyakrabban alkalmazott - véges differencia és véges elemes - módszere egyrészt összevethető a közös modell alapján, másrészt az eredmények is jobban kontrollálhatóvá válnak.

A hőtranszport folyamatok modellezéséhez szükséges számításokat a véges elemes Feflow rendszerben volt lehetőségem elvégezni, ugyanis a rendelkezésemre álló Modflow Pro szoftver a szivárgáson kívül csak anyagtranszport megjelenítésére képes. 


\section{IV.3. $\underline{\text { Adatok }}$}

\section{IV.3.1 A modellek felépitése}

A hidrodinamikai modell egy $10 \cdot 12 \mathrm{~km}^{2}$-es területet ábrázol, mintegy $1500 \mathrm{~m}$-es mélységtartományban. A felső és alsó határfelszínek vízszintes síkok, tengerszinthez viszonyított magasságuk $-1250 \mathrm{~m}$, illetve $-2750 \mathrm{~m}$ (4.9, 4.10 ábra).

A Feflow modellben 30 réteget definiáltam, melyek egyenként 50 m vastagságúak. Ehhez képest a Modflow modellben vertikálisan sűrítettem a vízrekesztő agyagmárgát és fedő törmelékes üledéket, így itt végül 50 réteg került lehatárolásra.

Mivel rétegek kiékelődése, metszése sem a Modflow, sem a Feflow rendszerekben nem megengedett, így az aljzati kristályos hát parametrizálása az egyes mélységszintekben zonálisan történt meg, élesen elkülönítve az üledékes formációktól. Így vált lehetségessé a $\mathbf{4 . 5}$ ábrán bemutatott geológiai szituáció modellbe ültetése.

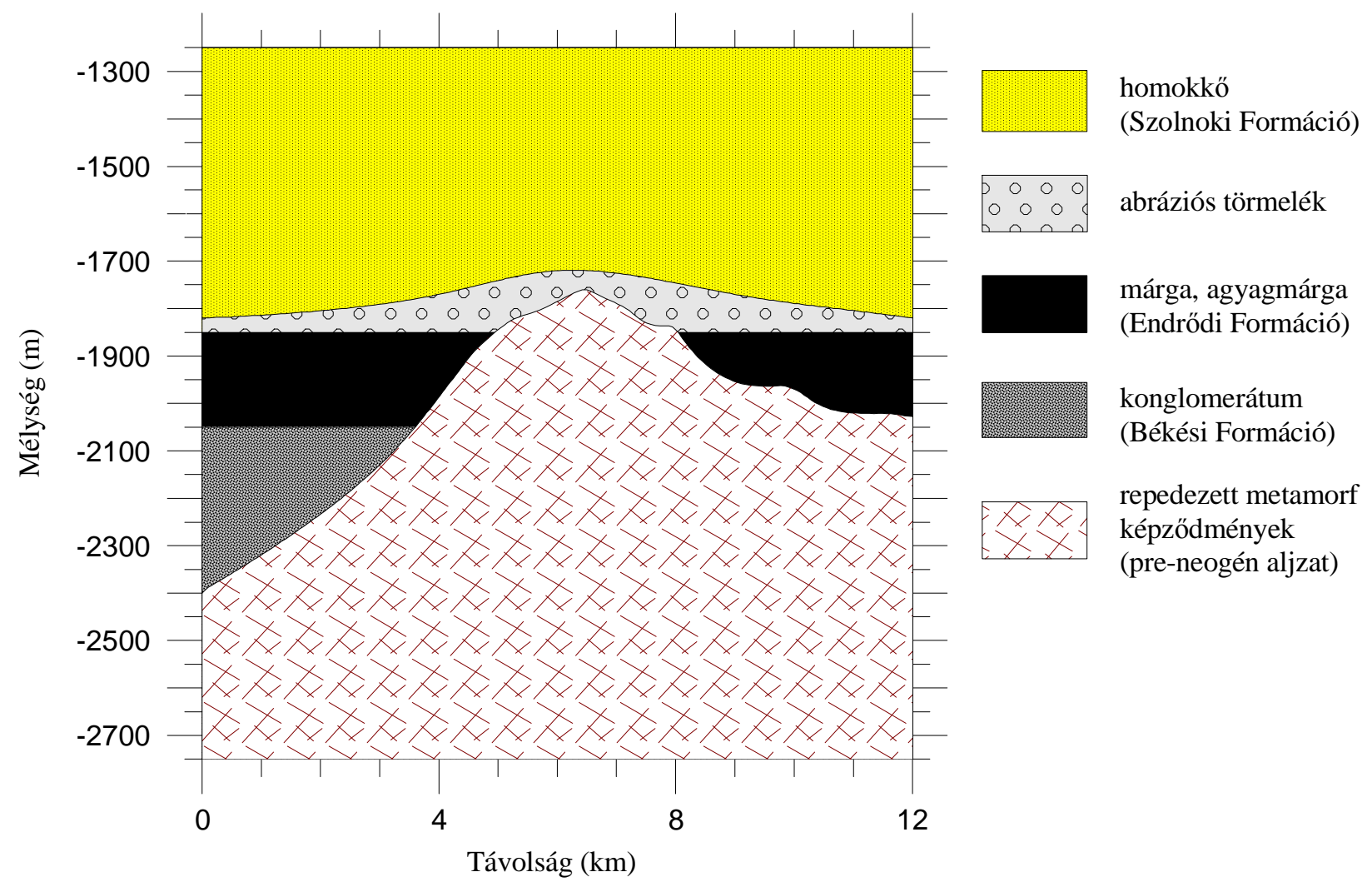

4.5 ábra Aljzati repedezett kiemelkedés és üledékes fedőképződményeinek geológiai szelvénye.

A modell magját a variszkuszi aljzati repedezett magmás-metamorf hát alkotja, melynek központi része $-1800 \mathrm{~m}$ magasságig nyúlik, legnagyobb mélysége pedig -2600 m a DNY-i sarokban. A kőzetegyüttest a Szeghalom dóm és a Békési-medencét körülölelő többi aljzati 
magaslat felépítésének analógiájára amfibolit és gneisz alkotja, melynek szerkezeti megoszlását a továbbiakban részletezem. Ezen a részen a kristályos blokk meredek lejtőjére a Békési konglomerátumot reprezentáló törmelékes üledékes réteg települ, mely középen kiékelődik, a modell peremén pedig eléri a $350 \mathrm{~m}$ vastagságot is. Fedőjében az alsó-pannóniai Endrődi Formációra jellemző, kvázi impermeábilis márga, agyagmárga összlet települ, melyet középen mintegy áttör az eróziónak egykor jobban ellenálló aljzati kiemelkedés. Mindezt a Pannon tó partvidéki régióiban ismeretes abráziós törmelék borítja, a modell szélei felé csökkenő szemcseméretet feltételezve. A sort felfelé a Szolnoki Formáció finomszemcsés homokkövei zárják.

\section{IV.3.2 Cellakiosztás}

Az ekvivalens kontinuum elven működő numerikus szimulátorok, mint a Modflow és Feflow egyik fő sajátossága, hogy az áramlási és transzport teret homogén tulajdonságokkal jellemzett egységekre osztja fel. Ennek mérete, a REV jelentősen eltérhet különböző szerkezetü kőzetek esetében. Dominánsan szemcseközi porozitással rendelkező képződményeknél természetesen a tektonikai elemektől eltekintve - ez a cm-es mérettartományban keresendö, míg fejlett repedéshálózattal rendelkező kőzetek esetén nagyságrendekkel nagyobb (>10 m), ahogy azt a III. 2 fejezetben is láttuk.

A modellben tehát, míg a porózus kőzeteket tartalmazó cellák méretének megválasztása tág határok közt változhat, a kristályos komplexum homogén áramlási tulajdonságú cellái méretének kijelölésénél az azt felépítő amfibolit és gneisz számított REV méretét (ld. III. fejezet) kellett figyelembe venni. Ezt a terület egyik legfontosabb, legrészletesebben kutatott tárolója, a Szeghalom metamorf dómból származó magminták repedéshálózatának geometriai paraméterei alapján számoltam. Jellemző példaként, az amf-1 és gne-1 magminták (4.6 ábra) a Szegh-2 illetve Szegh-15 fúrásokból származnak. 

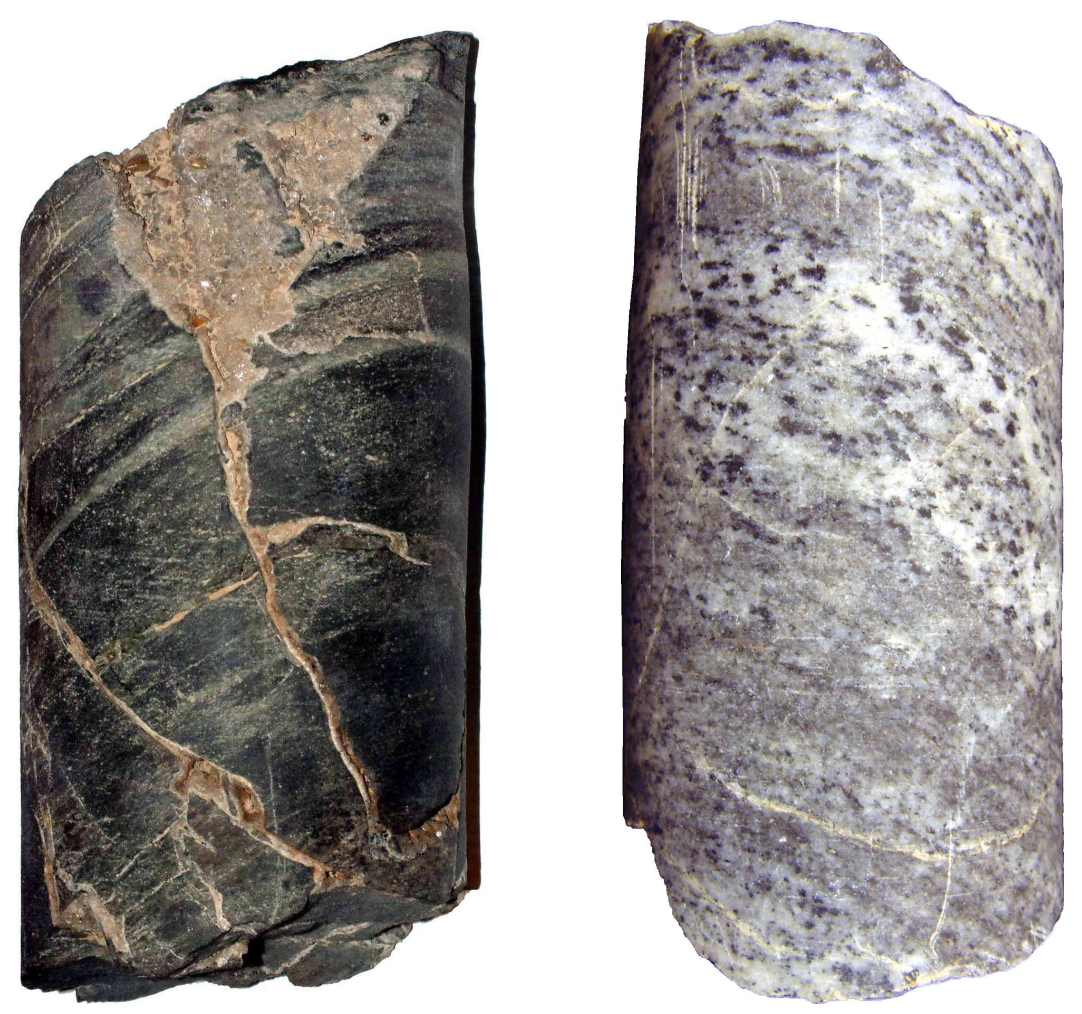

4.6 ábra Ásványi anyaggal kitöltött repedésekkel átszőtt amfibolit (balra) és gneisz (jobbra) magminta a Szegh-2 és Szegh-15 fúrásokból.

Az amfibolit esetén a repedések három különböző meredekségü síkcsoportba sorolhatók (két igen meredek egymás ellen dőlő és egy igen lapos), és a síkok közel azonos csapásiránnyal rendelkeznek. Mivel a két meredek dőlésủ csoportba tartozik a repedések meghatározó mennyisége, ezért csak ezek értékeit vettem figyelembe. A két meredek sík által bezárt szög átlagosan $65^{\circ}$. A hosszúságeloszlás $E$ paramétere -1,8 körüli értéknek felel meg, a fraktál dimenzió pedig a síkmetszetek dimenzióiból 1,3-nak adódott (M. Tóth és tsai, 2004) (4.1 táblázat).

A gneisz magmintán regisztrált repedéshalmazon egy lapos dőlésű és egy kevesebb számú törést tartalmazó meredek síkcsoport különíthető el, melyek csapásiránya hasonló, és az általuk bezárt szög $60^{\circ}$. A másik két paramétert, a hosszúságot és a fraktál dimenziót a következő értékekkel jellemezhetjük: $E=-2,5$ és $D=0,9$ (4.1 táblázat). 


\begin{tabular}{cccc}
\hline Magminta & $\mathbf{E}[-]$ & $\mathbf{D}[-]$ & $\boldsymbol{\alpha}\left[{ }^{\circ}\right]$ \\
\hline amf-1 & $-2,5$ & 0,9 & 60 \\
gne-1 & $-1,8$ & 1,3 & 65
\end{tabular}

4.1 táblázat Az amfibolit (amf-1) és gneisz (gne-1) magminták repedéshálózatát jellemző E-D- $\alpha$ paraméterhármas értékei.

A III.2 fejezetben részletezett módszert alkalmazva a fenti adatok felhasználásával meghatároztam az amfibolit és gneisz kőzettípusok jellemző REV méretét. Az amfibolit esetében a porozitás adatok relatív szórása 18 m-es felbontás esetén éri el a korábban definiált 20\%-os határt; a jellemző REV élhossz-méret ekkor $s=18$ m (4.7 ábra).

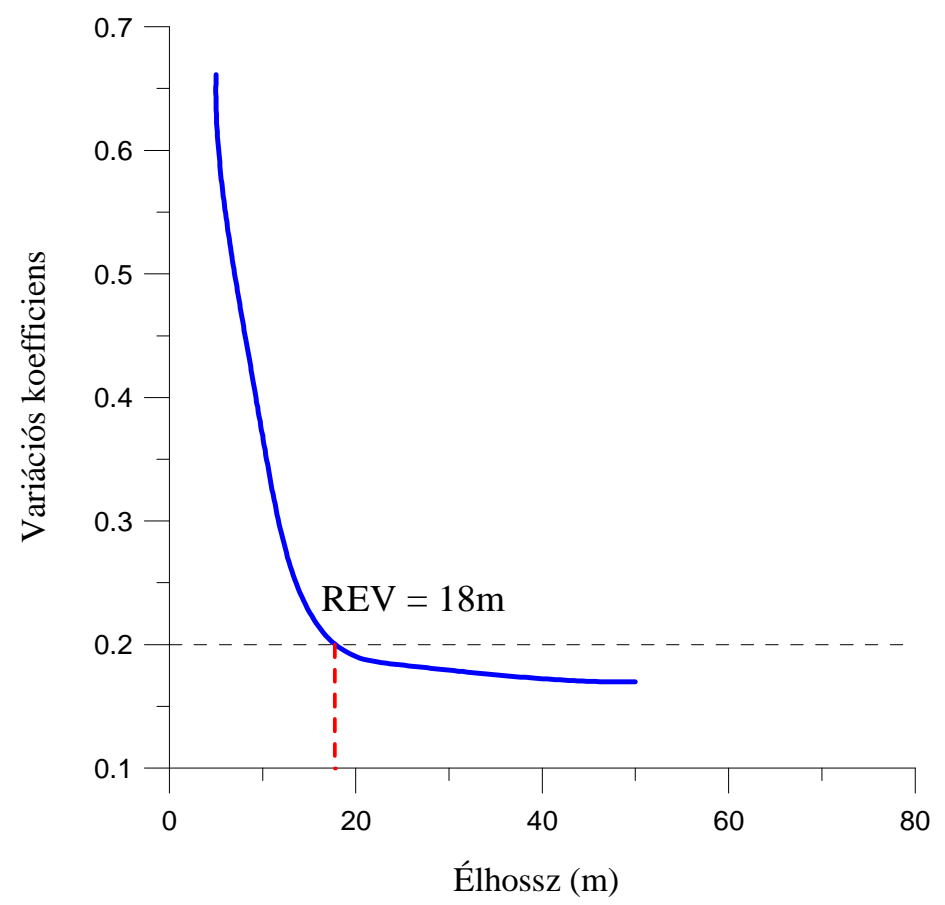

4.7 ábra Az amfibolitra jellemző reprezentatív elemi térfogat kijelölése a variációs koefficiens segítségével.

A gneisz mintára jellemző REV élhossz-méret többszöröse az amfibolitra jellemző értéknek, ez esetben $s=70 \mathrm{~m}$ (4.8 ábra). Ez a relatíve rövid és ritkán előforduló repedések jelenlétével magyarázható. 


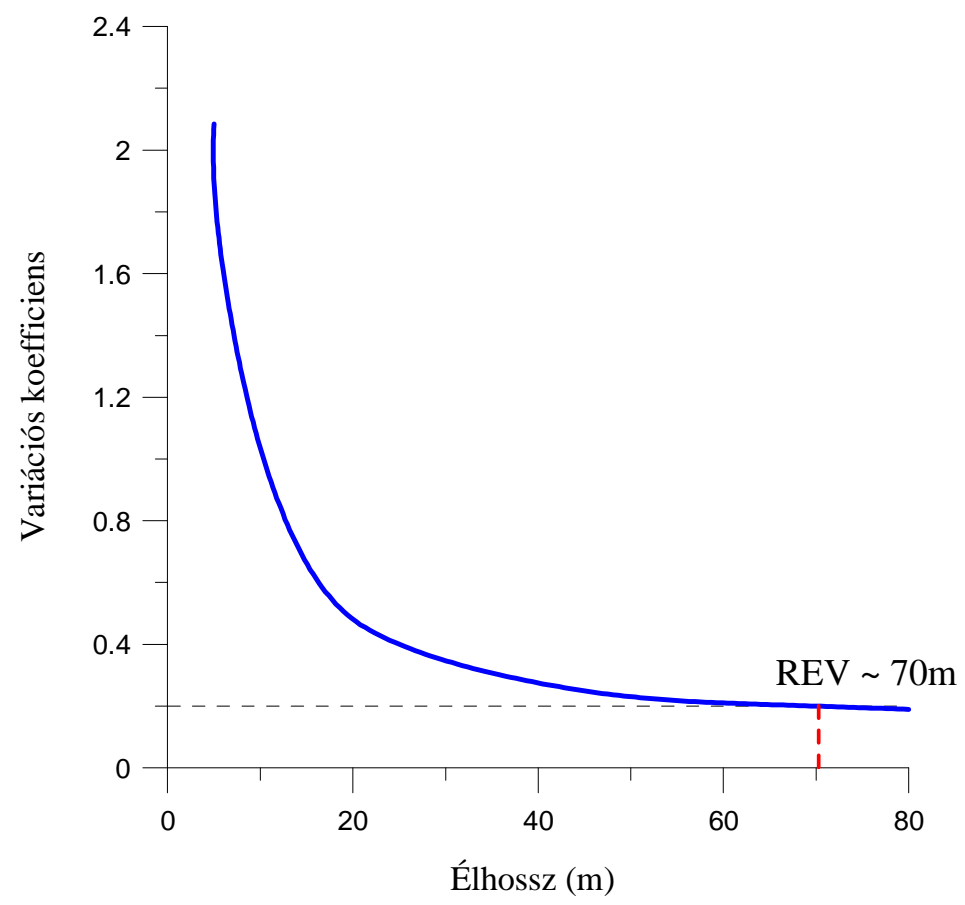

4.8 ábra A gneiszre jellemző reprezentatív elemi térfogat kijelölése a variációs koefficiens segítségével.

Ezek alapján a véges differencia modellben alkalmazott cellák élhosszát 100 m-nek adtam meg, ami - a kisebb mértékü lokális sürítésektől eltekintve - REV méret feletti homogenizációt jelent (4.9 ábra). A végeselemes modellháló kialakításakor szintén a 100 m-es gridpont-távolság megtartására törekedtem (4.10 ábra).
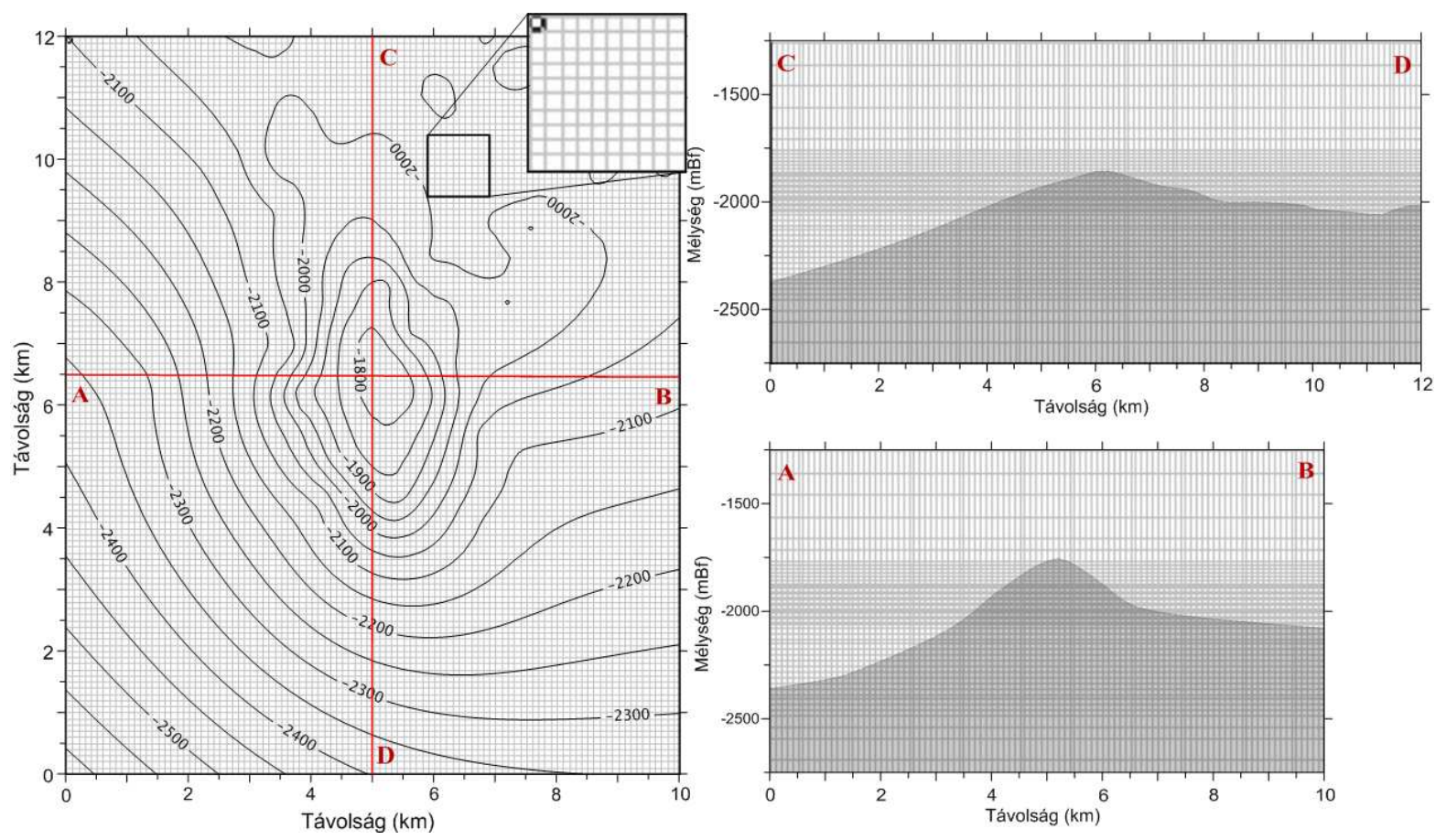

4.9 ábra A Modflow modell felülnézeti rácshálós képe (a), K-Ny-i (A-B) szelvénye (b), illetve É-D-i (C-D) szelvénye (c) az aljzati morfológia feltüntetésével. 

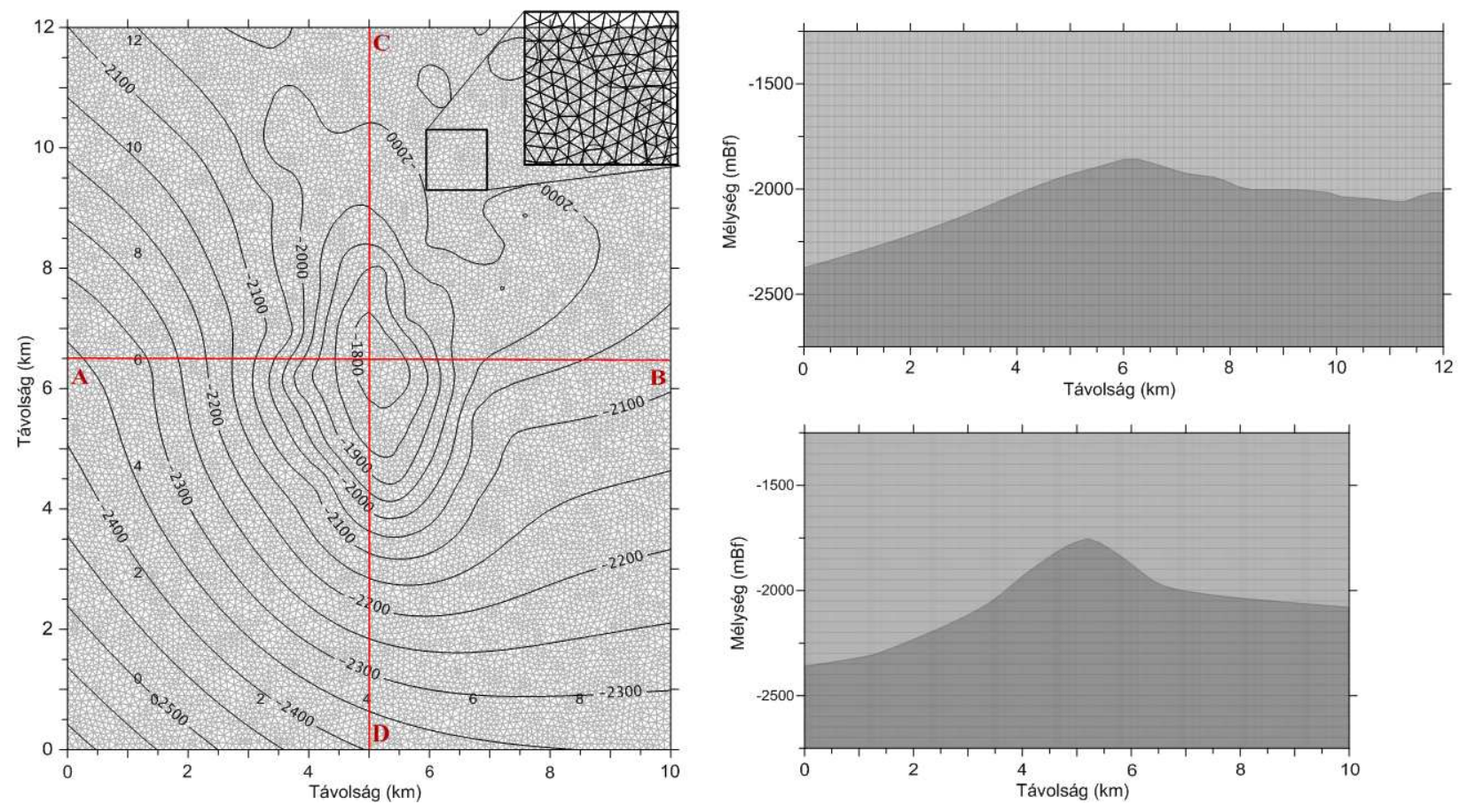

4.10 ábra A Feflow modell felülnézeti rácshálós képe (a), K-Ny-i (A-B) szelvénye (b), illetve É-D-i (C-D) szelvénye (c) az aljzati morfológia feltüntetésével.

\section{IV.3.3 Peremfeltételek}

\section{IV.3.3.1 Hidrodinamikai peremfeltételek}

A vízrekesztő agyag-agyagmárga rétegek esetében, a gravitációs és túlnyomásos hidrogeológiai egységek határán az uralkodó szivárgás vertikális, ezért az oldalról érkező vízmennyiség elhanyagolható mértékü. Ezeken a rétegeken zárt peremfeltételt definiáltam, a modell határa itt impermeábilisnak tekinthető, ezzel szemben a modell alsó és felső peremén a nyomáscsökkenés nem megengedett.

Oldalsó hozzááramlásra a kristályos aljzat lejtőjére lerakódott üledékekbe fix nyomású peremeken keresztül van lehetőség, vagyis ebből az irányból az utánpótlódás korlátlan.

\section{IV.3.3.2 Hötranszport peremfeltételek}

Habár a modellezett terület megválasztásánál arra törekedtem, hogy a belső folyamatok hatásai minél kevésbé legyenek érzékelhetők a határokon, a 17-28 rétegek oldalsó peremének egy részén, ahol jelentősebb beáramlás várható, valamint a legfelső rácson konstans hőmérsékleti feltételeket adtam meg. Itt, az egyes kőzetcsoportokat elválasztó felületek szélein a megfelelő mélységhez tartozó hőmérsékleteket a IV.3.5.1 fejezetben bemutatott, átlagos geotermikus gradiens 
alapján vettem figyelembe, a modell tetején $77,1{ }^{\circ} \mathrm{C}$ szélsőértékkel. A modell alsó felületén Neumann-típusú peremfeltételt definiáltam, ami a területre jellemző geotermikus viszonyok alapján $111.4 \mathrm{~mW} / \mathrm{m}^{2}\left(9625 \mathrm{~J} / \mathrm{m}^{2} \cdot \mathrm{d}\right)$ hőfluxus értékkel biztosítja a hőutánpótlást (ld. IV.3.5.3 fejezet).

\section{IV.3.4 Hidrodinamikai paraméterek}

A különböző modellrétegekben alkalmazott hidrodinamikai paraméterek összegző tábláját az E. melléklet tartalmazza, részletes leírásukra az alábbi alfejezetekben térek ki.

\section{IV.3.4.1 Nyomásviszonyok}

Az Alföld medencekitöltő üledékes rétegeinek nyomásviszonyai többségében hidrosztatikus, vagy ahhoz közeli jelleget mutatnak. A felszíni morfológia és a gravitáció hatása az áramlási rendszerekre egészen a pannóniai rétegek alsó részéig nyomozható, az alsó-pannóniai Algyői Formációban, de a legtöbb helyen a feküjében található Szolnoki Formációban is még hidrosztatikushoz közeli pórusnyomásokkal lehet számolni (MOL adatbázis). Kivételt jelent ez alól például Szarvas térsége, ahol a túlnyomásos zóna már a Szolnoki Formációban megjelenik (MOL adatbázis; Almási, 2001).

Az alapmodellben a Szolnoki Formációt, valamint a feküjében található abráziós törmeléket reprezentáló 8-13 (Modflow), illetve 11-12 (Feflow) rétegek hidraulikus emelkedési magasságát egységesen 100 m-nek választottam. Mindemellet hidrosztatikustól eltérő nyomásprofilú, regionális be- és kiáramlási zónák vizsgálatával is foglalkoztam.

A modellben a túlnyomásos rezsim felső határát - ahogyan azt a legtöbb esetben az alföldi mélyfúrások többségének nyomásmérései is megerősítik - a vízrekesztő Endrődi Formáció jelöli ki. Ebben az alacsony permeabilitású zónában a felső gravitációs és alsó túlnyomásos áramlási rendszer közötti nyomásátmenet markánsan jelenik meg, a változás folyamatos, a gradiens itt a legnagyobb.

A modellben a kristályos aljzatot reprezentáló amfibolitot és gneiszet szintén meredek nyomásemelkedés és litosztatikushoz közeli nyomásértékek jellemzik (4.11 ábra). A gradienst Szeghalom, Endrőd, Köröstarcsa, Dévaványa, Biharkeresztes és Földes térségének aljzatot érintő kútjaiban mért nyomás-mélység profilok alapján határoztam meg (Almási, 2001). 


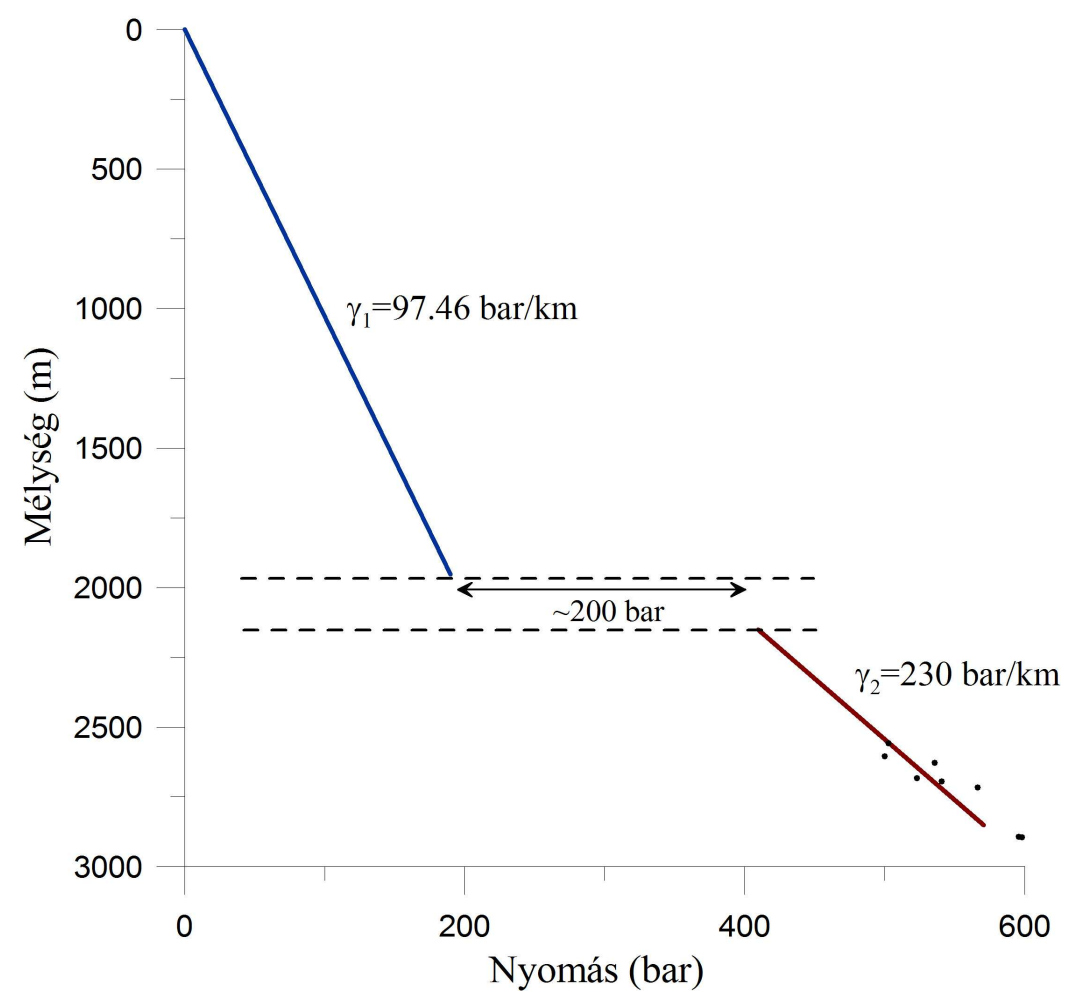

4.11 ábra A modell kezdeti hidraulikus emelkedési magasságainak alapjául szolgáló nyomás mélység profil (En-É-5-8, Mtúr-2, Köt-2-4 kutak adatainak feltüntetésével).

A felvázolt nyomásgradiens alapján az egyes zónák határára jellemző hidraulikus emelkedési magasságokat (Hubbert, 1940) a

$$
h=z+\frac{p}{\rho \cdot g}
$$

egyenlet alapján számítottam, ahol $z$ a vonatkoztatási sík (réteghatár) mélysége negatív előjellel, $p$ a nyomás, $\rho$ a víz sürüsége, $g$ pedig a gravitációs gyorsulás. A termálvíz sürüségét rezervoár kondíciók között úgy határozhatjuk meg, ha a standard, felszínen jellemző vízsürüséget osztjuk az adott mélységben jellemző víz teleptérfogati tényezőjével, továbbá

$$
B_{w}=\left(1+\Delta V_{w p}\right)+\left(1+\Delta V_{w T}\right),
$$

ahol

$$
\Delta V_{w T}=-1.0001 \cdot 10^{-2}+1.33391 \cdot 10^{-4} \cdot T+5.50654 \cdot 10^{-7} \cdot T^{2}
$$

a hőmérsékletváltozás hatására bekövetkező térfogatváltozást,

$$
\Delta V_{w p}=-1.95301 \cdot 10^{-9} \cdot p \cdot T-1.72834 \cdot 10^{-13} \cdot p^{2} \cdot T-3.58922 \cdot 10^{-7} \cdot p-2.25341 \cdot 10^{-10} \cdot p^{2}
$$

pedig a nyomásváltozás okozta térfogatváltozást fejezi ki (McCain, 1990). 


\section{IV.3.4.2 Porozitás}

Az alföldi olajkutató fúrásokból származó magmintákon végzett mérések (Szalay, 1982) arra utalnak, hogy az agyag és homokkő típusú kőzetek porozitása exponenciálisan csökken a felszíntől mintegy 2500 m-es mélységhatárig, majd onnan további, de jóval enyhébb redukció várható a hézagtérfogat alakulásában. A homok- és agyagkövek esetén 4500-5000 m-es mélységben már a kezdeti magas értékeknél egy nagyságrenddel kisebb porozitásról beszélhetünk. Ezt a trendet alkalmazva, az üledékes rétegek modellben használt mélység-korrekciós porozitását az alábbi táblázat szemlélteti (4.2 táblázat).

\begin{tabular}{ccccccc}
\hline \multicolumn{2}{c}{ Réteg } & \multicolumn{2}{c}{ Mélység [m] } & \multicolumn{3}{c}{ Effektív porozitás [-] } \\
Modflow & Feflow & - tól & $-i g$ & üledékes közetek & amfibolit & gneisz \\
\hline $1-2$ & $1-2$ & -1250 & -1350 & 0,26 & - & - \\
$3-10$ & $3-11$ & -1350 & -1800 & 0,25 & - & - \\
$11-13$ & 12 & -1800 & -1850 & 0,25 & 0,02 & 0,002 \\
$14-29$ & $13-16$ & -1850 & -2050 & 0,05 & 0,02 & 0,002 \\
$30-33$ & $17-18$ & -2050 & -2150 & 0,21 & 0,02 & 0,002 \\
$34-37$ & $19-20$ & -2150 & -2250 & 0,2 & 0,02 & 0,002 \\
$38-41$ & $21-22$ & -2250 & -2350 & 0,15 & 0,02 & 0,002 \\
$42-45$ & $23-24$ & -2350 & -2450 & 0,13 & 0,02 & 0,002 \\
$46-48$ & $25-28$ & -2450 & -2650 & 0,12 & 0,02 & 0,002 \\
$49-50$ & $29-30$ & -2650 & -2750 & - & 0,02 & 0,002 \\
\hline
\end{tabular}

4.2 táblázat A modellek egyes rétegeiben használt porozitás értékek.

A repedezett aljzati tároló amfibolit és gneisz kőzeteinek porozitását a RepSim programmal számítottam a III.2 fejezetben leírt módon. A hidrodinamikai és hőtranszport szimuláció bemeneti paramétere azonban az effektív porozitás, melynek meghatározásához először az amfibolit és gneisz kőzetek perkolációs vizsgálatát kell elvégezni a III.1 fejezetben bemutatott módszer segítségével.

A 4.1 táblázat input paraméterei alapján az amfibolit testek repedésrendszere 80-90\%-ban összefüggő (4.12 ábra). A kőzet átlagos porozitása $\phi ~ 2 \%$-nak adódott, ami a repedések összefüggősége miatt lényegében megegyezik az effektív porozitás értékével. 

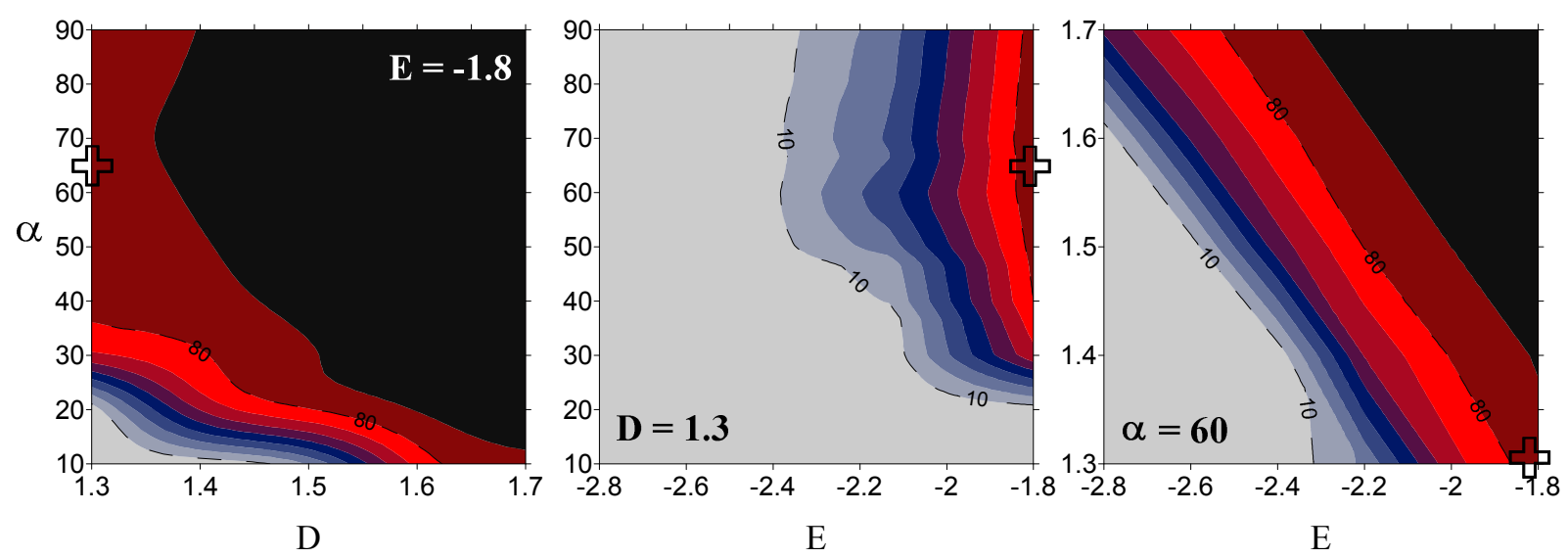

$0 \quad 10 \quad 20 \quad 30 \quad 40 \quad 50 \quad 60 \quad 70 \quad 8090(\%)$

4.12 ábra A legnagyobb perkolációs klaszter relatív mérete amfibolit típusú kőzetek esetén.

A gneiszben ezzel szemben számottevő összefüggő töréshálózat kialakulása nem valószínű. Bár a vizsgált gneisz minták jellemző fraktál dimenzió értéke kívül esik a nomogramok által lefedett tartományon, $E=-2,5$ mellett $D=1,3$ értéknél a legnagyobb perkolációs klaszter mérete $<10 \%$, ami $D \sim 0,9$ esetén tovább csökken (4.13 ábra).

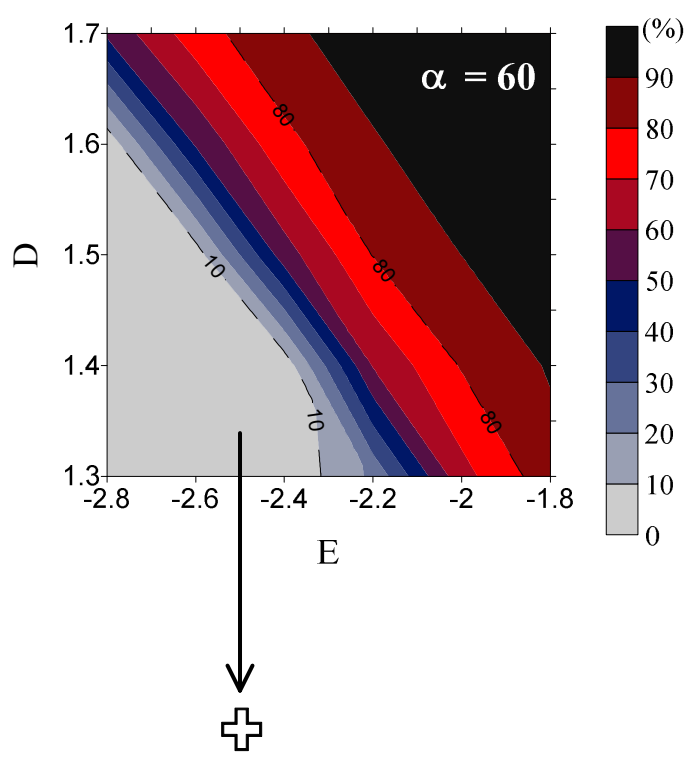

4.13 ábra A legnagyobb perkolációs klaszter relatív mérete gneisz típusú kőzetek esetén.

A kőzet teljes porozitása $\phi \sim 1 \%$, az effektív porozitás pedig még ezt az értéket sem éri el ezt a modellben extrém alacsony, az amfiboliténál egy nagyságrenddel kisebb porozitás értékek $(0,2 \%)$ megfeleltetésével oldottam meg. A Szeghalom környéki szénhidrogén termelési adatok megerősítik, hogy a gneisz litológiájú kőzetblokkokból is számolni kell kisebb mértékü beáramlással, ami alapvetően az esetenként előforduló kedvező szerkezeti helyzetnek, nagyobb 
tektonikai zónák jelenlétének köszönhető. Emiatt a kapott alacsony perkolációs értékek végső soron nem indokolják a gneisz teljes mértékü kizárását az áramlásból.

Az eredmények lényegében mind az amfibolit, mind a gneisz minták esetében egyeznek a korábbi vizsgálatok eredményeivel (M. Tóth és tsai, 2004). Mindez összességében arra utal, hogy a repedezett aljzat jó tároló és vezető zónái az amfibolitokhoz kapcsolódhatnak, míg a gneisz domének kevésbé vesznek részt az aljzati tároló hidrodinamikai rendszerében.

\section{IV.3.4.3 Permeabilitás, szivárgási tényezök}

Az üledékes képződmények közül a legrosszabb vízvezető tulajdonsággal az agyagos, márgás felépítésủ Endrődi Formáció rendelkezik. A tapasztalatok alapján a kőzet permeabilitása a laborvizsgálatokkal még meghatározható érték $\left(10^{-17} \mathrm{~m}^{2}\right.$, illetve $\left.0,01 \mathrm{mD}\right)$ alatt várható, a modellben $\mathrm{k}_{\mathrm{h}}=10^{-8} \mathrm{~m} /$ nap-ot választottam (Freeze and Cherry, 1979). A Békési konglomerátum a felsőpannóniai vízadó rétegekhez képest alacsony vízvezetőképességü Szolnoki homokkőnél valamivel jobb hidraulikai paraméterekkel rendelkezik; valamint hasonlóan nagyobb szivárgási tényezők jellemzik az aljzati magaslat fedőjében lévő abráziós törmelék központi zónáját is.

A vertikális szivárgási tényezők megadásánál minden üledékes réteg esetén egységesen $\mathrm{k}_{\mathrm{v}} / \mathrm{k}_{\mathrm{h}}=0,2$ arányt vettem figyelembe.

Az aljzatot felépítő amfibolit és gneisz kőzetek mátrix permeabilitása a gyakorlatban szinte elhanyagolható, a fluidum-áramlás teljes egészében a repedéshálózatban zajlik. A repedezett permeabilitás a rendelkezésre álló Szeghalom környéki fúrómagokon ugyan mérhető lenne laboratóriumi körülmények között, ám a repedezett kőzetek REV méretének nagysága (> $10 \mathrm{~m}$ ) miatt nem adna valós eredményt.

A repedezett közeg átlagos permeabilitás értékeit a RepSim-be épített algoritmusra hagyatkozva határoztam meg. Az áramlás modellező rendszerek igényei miatt végül az anizotrópiát nem az ellipszoid tengelyeinek hosszával és helyzetével, hanem x, y, z irányú értékekkel, majd ezek átlagolásával adtam meg. Eszerint az amfibolitnál $0.0109 \mathrm{mD}\left(1.1 \cdot 10^{-17} \mathrm{~m}^{2}\right)$, a gneisznél pedig $0.0849 \cdot 10^{-3} \mathrm{mD}\left(8.4 \cdot 10^{-20} \mathrm{~m}^{2}\right)$ permeabilitás értékeket kaptam.

A módszer további korrekciót igényelt, mivel a mag felszínre hozatalakor bekövetkező relaxáció miatt számolni kell a töréshálózat torzulásával, vagyis a nyitottság értékek megnövekedésével, ami végül a számított permeabilitás értékek pozitív eltéréséhez vezet.

A permeabilitás a valóságban a mélység és nyomás növekedésével monoton csökkenő tendenciát mutat (Morrow és Lockner, 1994); a KTB fúrás (Morrow és tsai, 1994) amfibolit és gneisz mintáin végzett laboratóriumi vizsgálatok például azt mutatják, hogy 25 MPa nyomáson a 
permeabilitás kb. egy-másfél nagyságrenddel csökken a felszíni körülményekhez képest. A kapott értékeket ennek megfelelően csökkentettem, végül a bemenő szivárgási tényezők előállításánál a fluidum viszkozitásának hőmérséklet-függését is figyelembe vettem (a Feflow ehhez beépített algoritmussal rendelkezik).

Fontos megjegyezni, hogy a RepSimmel számított permeabilitás értékek mellett a hagyományos és teszteres rétegvizsgálatok szolgáltathatnak még releváns adatokat a REV feletti mérettartományban, ilyen adat azonban nem állt rendelkezésemre.

\section{IV.3.5 Hötranszport paraméterek}

A különböző modellrétegekben alkalmazott hőtranszport paraméterek összegző tábláját a hidrodinamikai paraméterekkel együtt az E. melléklet tartalmazza, részletes leírásukra az alábbi alfejezetekben térek ki.

\section{IV.3.5.1 Hömérséklet eloszlás}

A kiindulási hőmérsékletek megadásakor a modell egész területén konstans geotermikus gradiens értéket vettem figyelembe. Ehhez a 4.1 ábra térképén bemutatott aljzati magaslatokat elérő mélyfúrások talphőmérséklet értékeiből (Dövényi és tsai, 1983) számított átlagot használtam, mely a figyelembe vett $8 \mathrm{db}$ kút alapján $49,7^{\circ} \mathrm{C} / \mathrm{km}$-nek adódott. A felhasznált kutak és a mért hőmérsékletek listáját a 4.3 táblázat szemlélteti.

\begin{tabular}{ccccc}
\hline Helység & Kút jele & Mélység [m] & Hőmérséklet $\left[{ }^{\circ} \mathbf{C}\right]$ & Geotermikus gradiens [ $\left.{ }^{\circ} \mathbf{C} / \mathbf{k m}\right]$ \\
\hline Dévaványa & Deva-1 & 2485 & 142 & 52,3 \\
Dévaványa & Deva-2 & 2710 & 140,5 & 47,4 \\
Endrőd & En-2 & 2382 & 141 & 54,2 \\
Gyoma & Gyo-1 & 2817 & 134 & 43,3 \\
Sarkadkeresztúr & Sark-35 & 2720 & 138 & 46,3 \\
Sarkadkeresztúr & Sark-36 & 2940 & 157 & 49,3 \\
Szarvas & Szr-4 & 2593 & 140 & 49,4 \\
Szeghalom & Sz-2 & 1959 & 121 & 55,6 \\
\hline
\end{tabular}

4.3 táblázat Az aljzatot elérő mélyfúrások talphőmérséklete és ez alapján számított geotermikus gradiens értéke.

A modell területre meghatározott geotermikus gradiens értékből kiindulva a Feflow modell minden egyes határfelületére (“slice”) konstans kezdeti hőmérsékletértéket definiáltam a

$$
T_{\text {grad }}=\frac{\Delta T}{\Delta z}+T_{0}
$$

képlet alapján, ahol $\mathrm{T}_{0}=11{ }^{\circ} \mathrm{C}$ az éves átlagos középhőmérséklet. 


\section{IV.3.5.2 Hövezetöképesség}

A hővezetőképesség a hőmérséklet térbeli és időbeli eloszlásának jellemzésére szolgáló belső anyagi tulajdonság, mely stacioner körülmények között jelzi a hőáramlási viszonyokat. Adott anyag hővezetőképessége több tényezőtől függ, nagyságát legjobban az ásványos összetétel, a porozitás, a fluidum-telítettség és a hőmérséklet befolyásolja.

Az első esetben a hővezetési tényező nagyságára a magas (kvarc, halit, anhidrit, dolomit), közepes (kalcit) és alacsony (agyagásványok) hővezetőképességü ásványos elegyrészek részaránya a szignifikáns hatótényezö.

A második tényezőnek, a porozitásnak szintén jelentős szerepe van a hővezetőképesség alakulásában. A tapasztalati adatok azt mutatják (Brigaud és tsai, 1990), hogy azonos összetétel esetén0 az elhanyagolható porozitással rendelkező kőzetek hővezetési tényezője akár háromszorosa is lehet a 40-50\%-os hézagtérfogattal rendelkező kőzetekhez képest. A jelenség alapvetően a porozitásból következő fluidumtartalommal magyarázható, ugyanis a víz jóval rosszabb vezető (0,6 W/mK $20{ }^{\circ} \mathrm{C}$-on), mint a kőzetmátrix, s ezáltal a telítettség csökkenése a hővezetőképesség javulását eredményezi.

Ugyancsak tapasztalati adatokból tudjuk, hogy a hőmérséklet is jelentős hatással van a kőzetmátrix - és kisebb mértékben a fluidum - hővezetőképességének nagyságára (Roy és tsai, 1981). A hőmérsékleti korrekciót (Chapman és tsai, 1984), feltételezve hogy a kőzetmátrix vezetőképessége arányos az abszolút hőmérséklettel, a

$$
\lambda_{m, T}=\lambda_{m, 20} \cdot[293 /(273+T)]
$$

összefüggés alapján tehetjük meg, ahol $\lambda_{\mathrm{m}, \mathrm{T}}$ és $\lambda_{\mathrm{m}, 20}$ a kőzetmátrix hővezetési tényezője T rezervoár hőmérsékleten, illetve $20{ }^{\circ} \mathrm{C}$-os laboratóriumi körülmények között. Ez az összefüggés elsősorban medencekitöltő üledékekre érvényes, ám a magmás-metamorf kőzetek hővezetőképességében is ennél kisebb mértékben ugyan, de - hasonló tendencia mutatható ki (Clauser és Huenges, 1995).

A modellben a Szolnoki és Endrődi Formációk jellemző hővezetési tényezőjét Dövényi és társai (1983) mérései alapján a Sándorfalva S-I fúrás rétegsorában mért alsó- és felső-pannóniai korú homokkő, aleurolit és agyagmárga mintáinak (20 db) átlagértékéből, valamint alsó- és felsőpannóniai korú márga és agyagkő mintáinak $(8 \mathrm{db})$ átlagértékéből számítottam.

Az ásványok közül a kvarc az egyik legjobb hővezető, ami a gneiszben dúsulva növeli annak hővezetési tényezőjét. A modellben használt értékek a Sándorfalva S-I fúrás 3850-4000 m közötti mélységtartományából származó paleozóos gneisz magok értékeit reprezentálják (Dövényi 
és tsai, 1983). Ehhez képest az amfibolit általában kisebb értékekkel jellemzhető az alacsonyabb hővezetéssel jellemzett színes elegyrészeknek (hornblende) köszönhetően (Clark, 1966).

A modellbe illesztés előtt a bemutatott hővezetési tényezőkön, a porozitásról, illetve fluidumtartalomról való információ függvényében hőmérsékleti korrekciót végeztem el (4.4 táblázat).

\begin{tabular}{lcc}
\hline \multicolumn{1}{c}{ Kőzetegyüttes } & Átlagos hővezetési tényező $(\boldsymbol{\lambda})$ & $\begin{array}{c}\text { Hómérsékleti hatással korrigált } \\
\text { átlagos hővezetési tényező }(\boldsymbol{\lambda})\end{array}$ \\
\hline Szolnoki Homokkő & 2,20 & 1,78 \\
Abráziós törmelék & 2,80 & 2,18 \\
Endrődi Formáció & 1,97 & 1,50 \\
Békési konglomerátum & 2,80 & 2,03 \\
Gneisz & 3,44 & 2,92 \\
Amfibolit & 2,91 & 2,47 \\
\hline
\end{tabular}

4.4 táblázat A modellben használt litológiák jellemző hővezetési tényezői a hőmérsékleti hatással korrigált értékek feltüntetésével.

\section{IV.3.5.3 Höáram}

A Föld felszínén időegység alatt átáramló hőmennyiséget nevezzük felszíni hőáramnak, melynek nagyobb része a köpenyből, kisebb része a kéregből származik (Beardsmore és Cull, 2001). Á Oltalánosságban elmondható, hogy a hő a köpenyen keresztül konvekcióval, a kéregben pedig alapvetően kondukció útján terjed.

A Föld felszínén mért konduktív hőáram átlagos értéke $87 \pm 2 \mathrm{~mW} / \mathrm{m}^{2}$ (Pollack és tsai, 1993); az óceánoknál $101 \pm 2.2 \mathrm{~mW} / \mathrm{m}^{2}$, a szárazföldek felett pedig ennél lényegesen alacsonyabb $\left(65 \pm 1.6 \mathrm{~mW} / \mathrm{m}^{2}\right)$. Magyarországon az átlagnál nagyobb felszíni hőáramsűrüség jellemző, mely alapvetően a kora miocéntől nyomon követhető extenziós medencefejlődés következményeként kivékonyodott kontinentális kéregre vezethető vissza. Az országos átlag $~ 90 \mathrm{~mW} / \mathrm{m}^{2}$, a legnagyobb értékek a medence peremeken, valamint az aljzati kiemelkedések felett mérhetők. A felszíni hőáramot a hővezetőképesség és a geotermikus gradiens szorzataként kapjuk a következő összefüggés alapján:

$$
Q_{0}=\lambda \cdot \frac{\Delta T}{\Delta z} \quad\left[\mathrm{~mW} / \mathrm{m}^{2}\right]
$$

A modell felső részére jellemző hőáramsürüség meghatározásához először figyelembe vettem az üledékes fedőkőzetek hőmérsékleti hatással korrigált hővezetőképesség értékeit az egyes modellrétegekre, majd ezeknek számítottam a harmonikus középértékét $\left(\lambda_{1}=2,1 \mathrm{~W} / \mathrm{mK}\right)$. Az aljzati 
amfibolit és gneisz kőzeteknél hasonló módon jártam el, itt azonban - a blokkos elrendeződés miatt - a hővezetőképességek aritmetikai közepét $\left(\lambda_{2}=2,61 \mathrm{~W} / \mathrm{mK}\right)$ használtam. Végül a felső üledékes és alsó kristályos rezsim átlagos hővezetési tényezőiből újabb harmonikus közepet $\left(\lambda_{3}=2,21 \mathrm{~W} / \mathrm{mK}\right)$ számoltam, és ezt szoroztam a geotermikus gradienssel $\left(\mathrm{T}_{\mathrm{grad}}=49,7{ }^{\circ} \mathrm{C} / \mathrm{km}\right)$. A felszíni hőáramsürüség a modell területén így $111,9 \mathrm{~mW} / \mathrm{m}^{2}$.

A kéregben a radiogén hőképződés nem egységes, a radioaktív elemek főként a savanyú magmás és gránithoz hasonló összetételü metamorf kőzetekben koncentrálódnak. Ennek a hőnek a 98\%-a az urán $\left({ }^{238} \mathrm{U}\right)$, tórium $\left({ }^{232} \mathrm{Th}\right)$ és kálium $\left({ }^{40} \mathrm{~K}\right)$ izotópjainak hasadásából származik. Ha bizonyos mélységszint jellemző hőáramát $\left(q_{z}\right)$ akarjuk meghatározni, akkor a felsorolt radioaktív elemek által termelt hőt (I) ki kell vonnunk a felszíni hőáramból:

$$
q_{z}=Q_{0}-I z
$$

A modell alsó peremén lévő hőáramsürüség értékét az aljzati kristályos komplexum hőtermelésével csökkenteni kell. A gneisz és amfibolit belső hőképződésére $I_{g n e}=1,2 \mu \mathrm{W} / \mathrm{m}^{3}-\mathrm{t}$ illetve $I_{a m f}=0,37 \mu \mathrm{W} / \mathrm{m}^{3}$-t vettem Cermak és tsai (1990) tapasztalati adatsora alapján, ami a modell alján $\mathrm{kb} .0,5 \mathrm{~mW} / \mathrm{m}^{2}$ höáram csökkenést eredményez. Így végül $q_{-2750}=111,4 \mathrm{~mW} / \mathrm{m}^{2}$ adódott.

\section{IV.3.5.4 A közet és a fluidum fajlagos hökapacitása}

A bemenő fajlagos hőkapacitás értékeket irodalmi adatok (Somerton, 1992; Stüwe, 2007) alapján határoztam meg és rendeltem hozzá a hőtranszport modellben felépített kőzetformációkhoz. A hőkapacitás mélység szerinti alakulásában - a hővezetőképességgel ellentétben - egy növekvő trend figyelhető meg (Somerton, 1992), így ezt mind a kőzet, mind a fluidum input adatainál figyelembe vettem, és a hőmérsékleti korrekciót elvégeztem.

\section{IV.3.6 Szimulációs paraméter beállítások}

A hidrodinamikai és hőtranszport modellezés során a hidraulikus emelkedési magasságok és a hőmérsékleteloszlás számítását permanens állapotra végeztem. Konvergencia kritériumnak az úgynevezett euklideszi integrál (RMS) normalizálást választottam, küszöbértékként pedig $10^{-5}-\mathrm{t}$ vettem fel, törekedve a számítások pontosságára. A numerikus eredmények stabilizására a „streamline upwind” módszert választottam, ami a modell szélein egyébként megjelenő hőmérséklet oszcillációkat hatékonyan kiküszöbölte. 


\section{IV.4. A modellezés eredményei}

\section{IV.4.1 Vízáramlás modellezés eredményei}

A szimuláció előtti, alapparaméterekkel felruházott hidrodinamikai modell azt az alapállapotot reprezentálja, amikor a regionális tektonikai mozgások okozta kompresszió (miocén) az aljzati nyomás jelentős megemelkedéséhez vezetett. Ott, ahol később kvázi impermeábilis fedőüledékek rakódtak le nagy vastagságban, a túlnyomás általában megőrződött és az áramlási rendszer elszigetelődött a felette elhelyezkedő hidrosztatikus rezsimtől. Ahol azonban az aljzat morfológiája miatt a szigetelő üledékes réteg elvékonyodott vagy hiányzik, a hidraulikai kapcsolat ki tudott alakulni a két zóna között. A valóságban ez a nem ritka geológiai-hidrogeológiai szituáció folyamatosan alakulhatott ki a felső-miocén inverzió (Fodor, 2010) kezdetétől.

A szimulációval, eltekintve a feszültségtér időbeli változásától, egy kvázi stacionárius állapotot közelítettem, ahol a megadott peremfeltételek által szabályozva az aljzati repedezett tárolón keresztül kompenzálódni képes a felhalmozódott túlnyomás. Az egyensúly beállta után az ekvipotenciális vonalak továbbra is sürün, vízszintesen futnak a vízrekesztő márga-agyagmárga rétegekben, ahol az alacsony vertikális szivárgási tényezőknek köszönhetően a nyomás a nagy hidraulikus gradiens ellenére sem tud kiegyenlítődni (4.14 ábra).

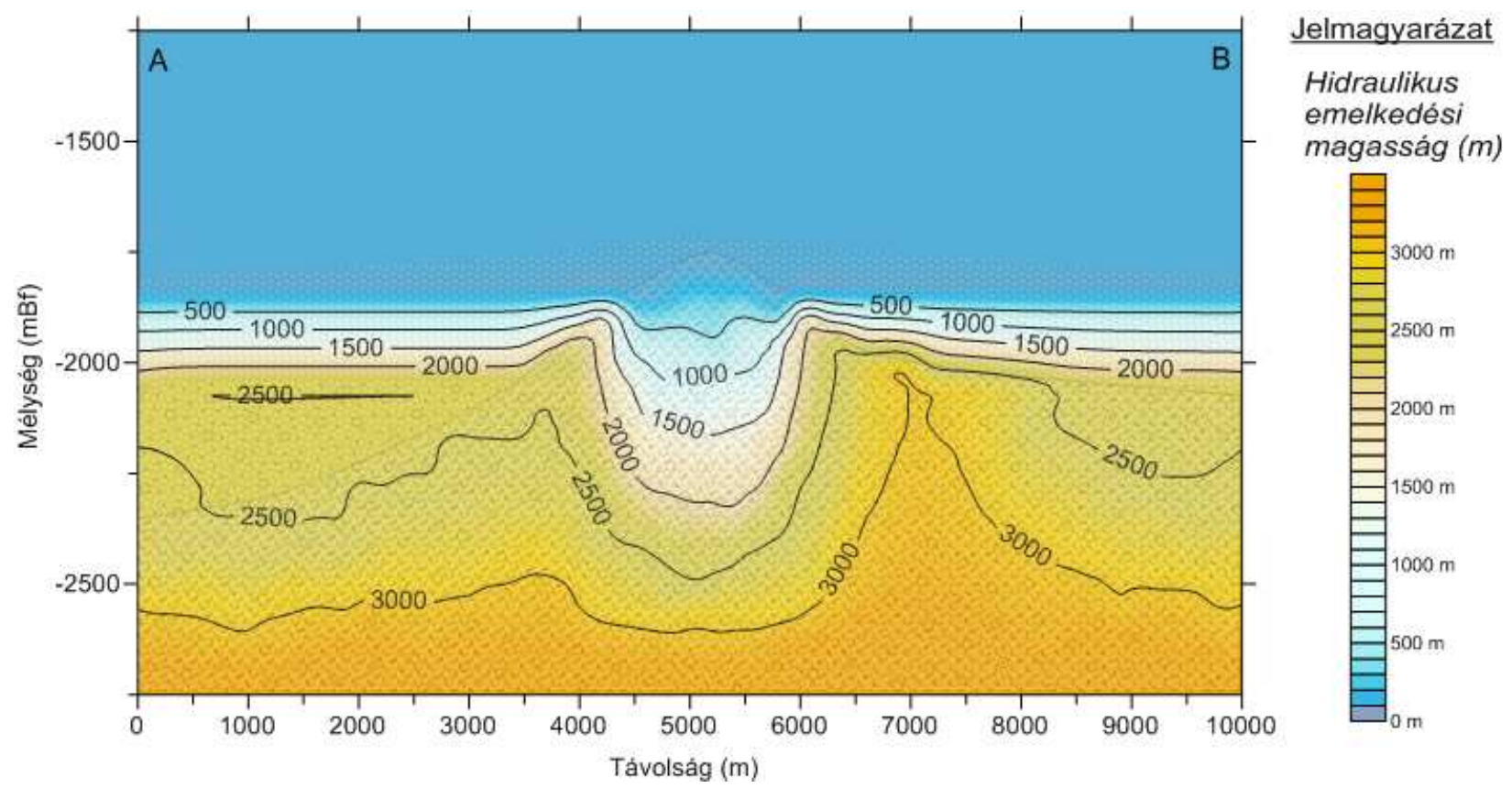

4.14 ábra A hidraulikus emelkedési magasságok alakulása a modell közepét átszelő, Ny-K irányú vertikális metszeten (A-B szelvény, ld. következő ábra).

Az agyag alatt, a repedezett kőzettest belsejében azonban jelentős depresszió alakul ki - a mélyebb túlnyomásos rezsim kompressziója miatt az alsó régióban folyamatos az utánpótlódás, a 
középső határsávban és az felett, a gravitációs áramlási rezsim alján viszont lokálisan negatív nyomás-anomáliákra számíthatunk. Itt az adott mélységszintre jellemző értékeknél kisebb nyomású zóna jön létre (4.15 ábra), melynek következményeként a kristályos komplexum lejtőjén felhalmozódott durvatörmelékes kőzetekből a fluidum beszivárog az aljzat töréshálózatába (Vass és tsai, 2009). Mindez megtörténik annak ellenére, hogy a gneisz és amfibolit kőzetek permeabilitása nagyságrendekkel kisebb a rá települő konglomerátumra jellemző értékeknél.

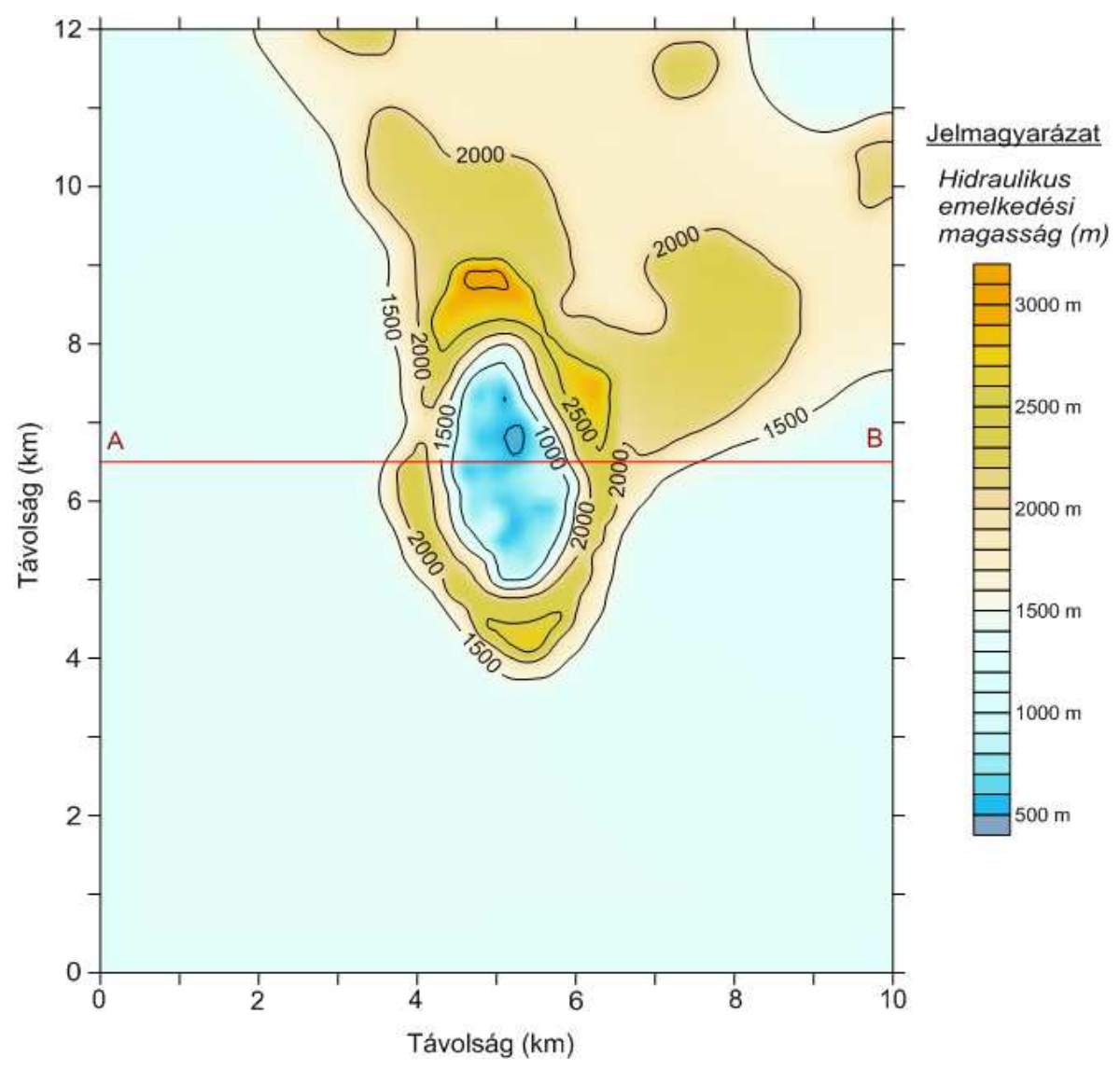

4.15 ábra A hidraulikus emelkedési magasságok alakulása a 15. modell rétegben.

A szivárgási sebesség a nagy fluxus miatt ugrásszerüen megnő, és a „kémény” belsejében egy viszonylag gyors feláramlás valósul meg (4.16 ábra). A fluidum-áramlás a modell szélei felől a kristályos hát központi része felé tart, majd a kémény belsejébe érve felfelé irányul. Az áramlási sebesség egyre nagyobb, maximumát a kristályos mag tetejénél éri el. 


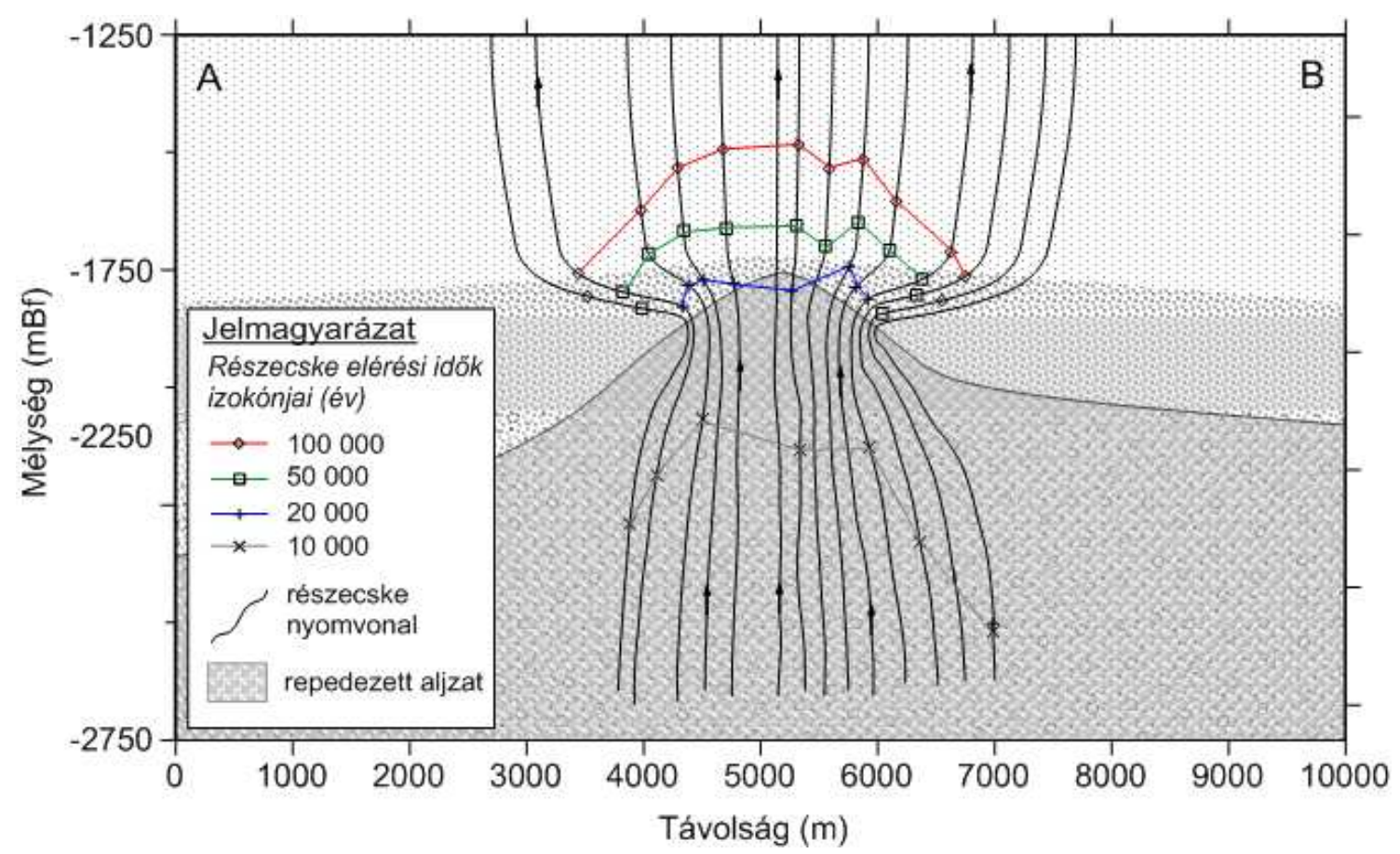

4.16 ábra A modell alsó régiójából induló vízrészecskék nyomvonala keresztmetszeti képen, az érkezési idők feltüntetésével - kiáramlási terület.

A hidrodinamikai modell alátámasztja azt a geokémiai adatok alapján ismert jelenséget, miszerint a mélységi fluidum - mely az alsó-pannóniai homokkövekben már a túlnyomás kiegyenlítődésével mérsékeltebb ütemben szivárog - idővel bekapcsolódik és keveredik a gravitációs áramlási rendszerekben mozgó, általában alacsonyabb sótartalmú, fiatalabb $\mathrm{HCO}_{3}$-os vizekkel. A felső-pannóniai és pleisztocén vizek regionális kiáramlási zónái (Tisza-mente, Tiszántúl nagy része) alól érkéző sós fluidum közvetlenül felfelé (4.17 ábra), míg a betáplálási területek (Duna-Tisza köze) alatti aljzati magaslatokból származó fluidum laterálisan eltérítve folytatja útját a felszín felé (4.18 ábra) (Mádlné Szőnyi és tsai, 2005; Mádl-Szőnyi és Tóth, 2009). 


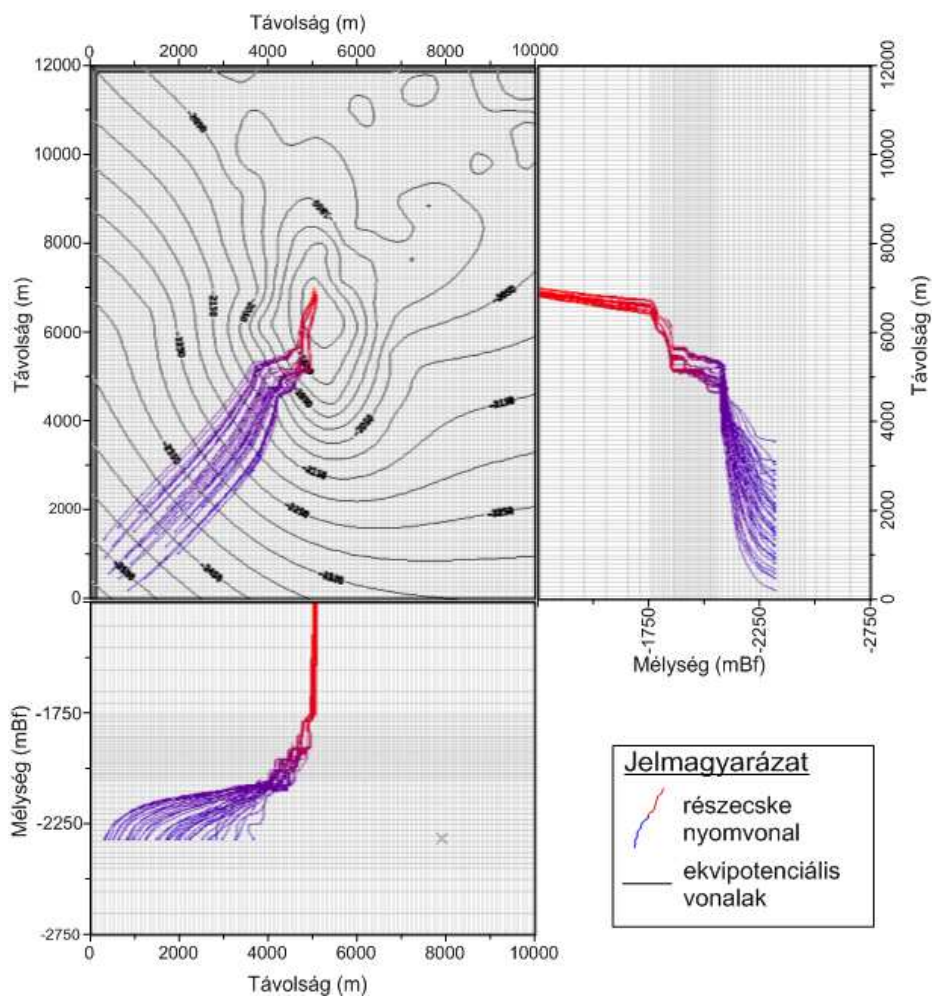

4.17 ábra Az aljzati magaslat lejtőjét fedő üledékes kőzetből induló vízrészecskék nyomvonalai keresztmetszeti képen - kiáramlási terület.

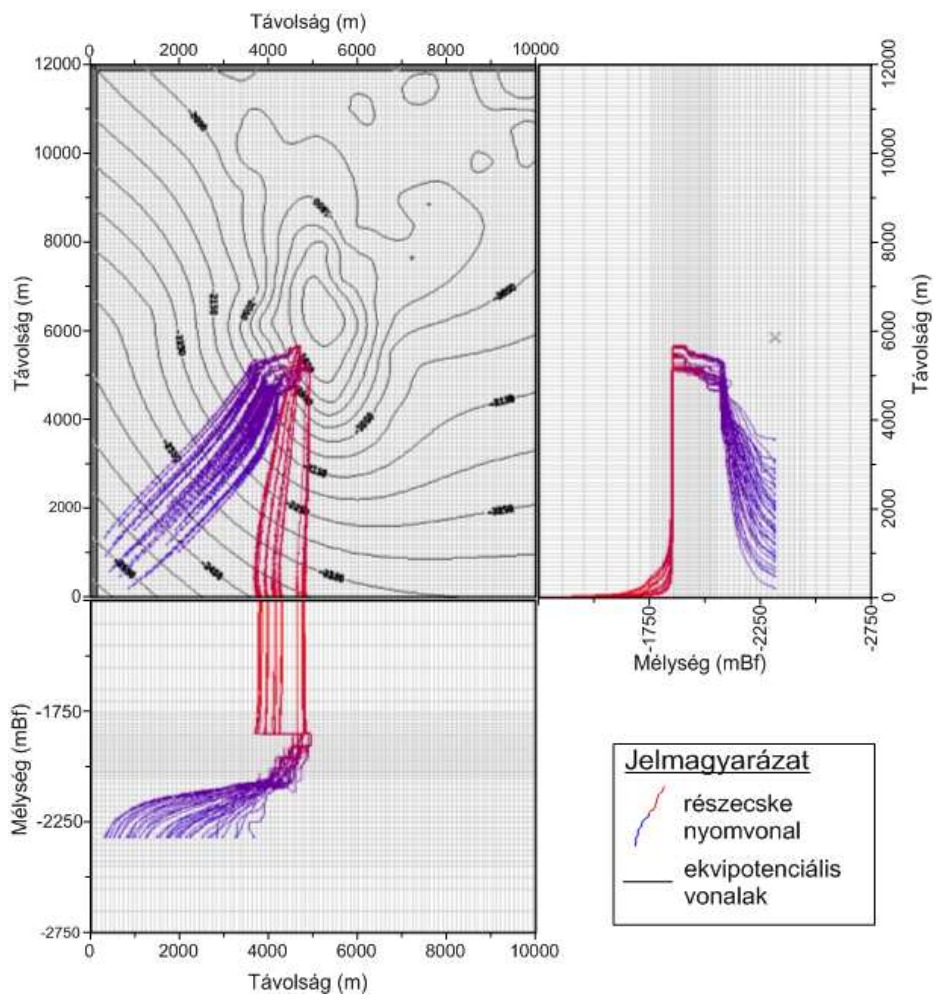

4.18 ábra Az aljzati magaslat lejtőjét fedő üledékes kőzetből induló vízrészecskék nyomvonalai keresztmetszeti képen - beáramlási terület. 


\section{IV.4.1.1 A litológia szerepe}

Az aljzati metamorf képződmények szerkezeti elrendeződése, geometriája fontos tényező lehet az áramlási sajátosságok, áramlási pályák kialakításában. A valóságban ez persze nagyon sokszínű és bonyolult képet mutat, ám kellő egyszerüsítést alkalmazva a modellel is jól bemutathatók a litológiai és szerkezeti változatosság okozta alapvető különbségek. Ennek szemléltetésére kétféle forgatókönyvet készítettem: az első ( $S c 1)$ determinisztikus esetben hipotetikus szerkezeti elemekkel elválasztott, kiterjedt amfibolit és gneisz blokkok (4.19 ábra) alkotják az aljzati magaslatot, míg a másodikban $(S c 2)$ a két képződmény sokkal kisebb blokkokat alkotva, véletlenszerúen váltakozva tölti ki a teret (4.20 ábra).

A nyomás kiegyenlítődésével az $S c 1$ és $S c 2$ esetben egyaránt, a vízrészecskék más és más pályákat járnak be, ami - az aljzati képződményeket tekintve - az amfibolit testek domináns hidrodinamikai szerepének köszönhető. Ezt jól mutatja az izobárok lehajlása az amfibolit blokkok határán, illetve a blokkok belsejében kialakuló nagyobb anomáliák. A különbség határozottabban jelentkezik a nagyobb blokkok esetén $(S c 1)$, de $S c 2$-ben is könnyen azonosítható. A jól repedezett amfibolitban sokkal intenzívebb feláramlás valósul meg, ugyanis hiába nagyobb a gneisz hidraulikus gradiense, az amfibolit szivárgási tényezőjében megfigyelhető nagyságrendnyi pozitív irányú differencia miatt ez utóbbiban nagyobb fluxus alakul ki. Az aljzati túlnyomás végül a rosszabb vezetőképességű gneiszben is képes kiegyenlítődni, ám a feláramlás elsősorban az amfibolithoz kötődik.

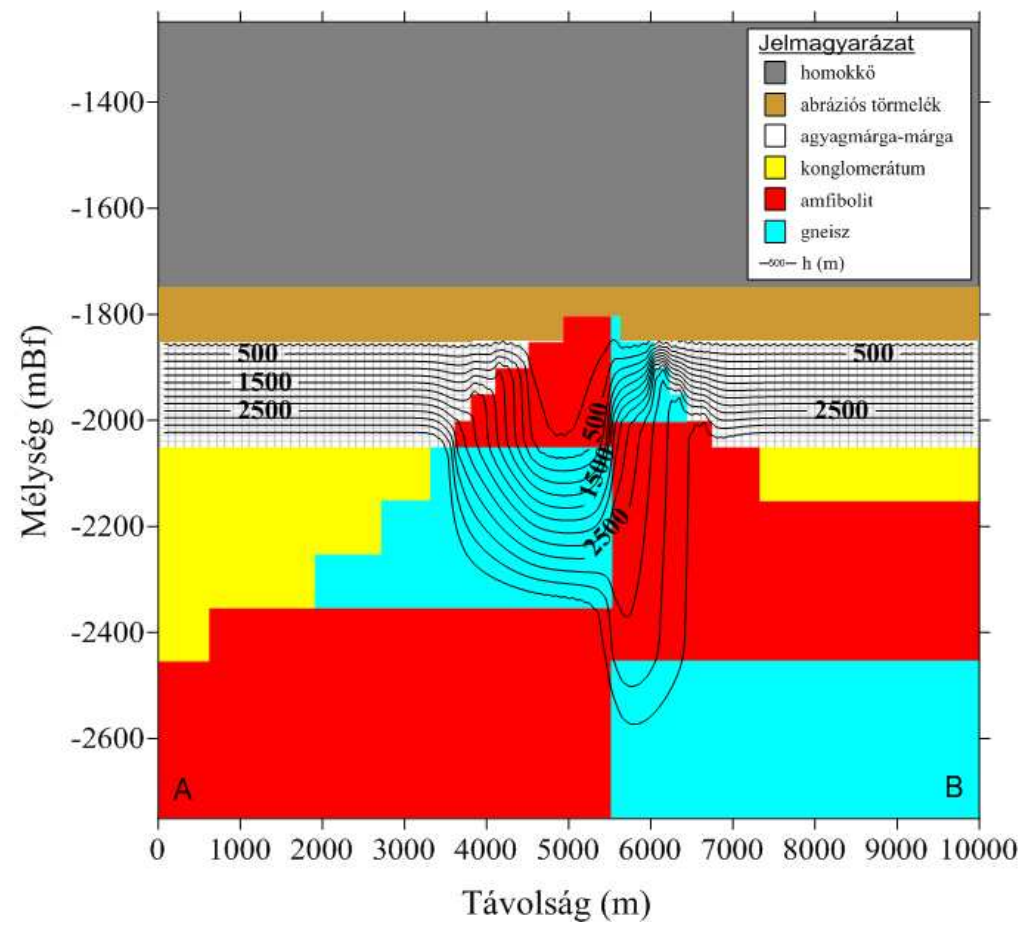

4.19 ábra A potenciál (m) alakulása nagyobb blokkos aljzati felépítés esetén $(S c 1)$. 


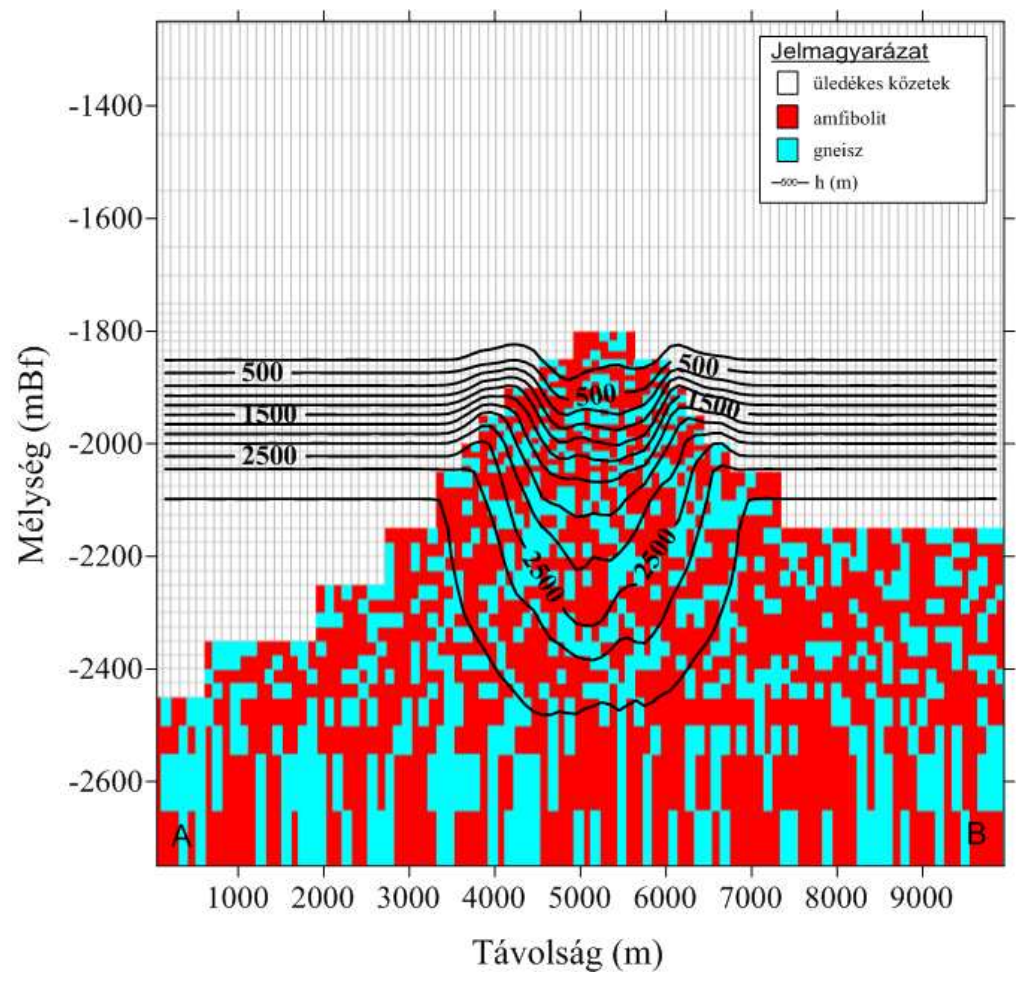

4.20 ábra Sürün váltakozó amfibolit-gneisz cellák hatása a potenciál (m) alakulására $(S c 2)$.

Az aljzati, egymással kommunikáló és egymástól elszigetelt kőzetblokkok fluidumáramlásban betöltött eltérő szerepét egy más szemléletű megközelítéssel, a fluidumzárványok komplex elemzésével is alá lehet támasztani. Ennek alapja, hogy a repedésrendszerben egykor migrált fluidumok a cementáció során a repedéskitöltő ásványokban, mint fluidumzárványok csapdázódhattak, amiből a bezáródás fizikai körülményeire, valamint az egykori folyadékok összetételére kaphatunk választ. A Szeghalom dóm Sz-2, Sz-20 és Sz-11 jelü fúrásaiból, a repedezett metamorf aljzatot feltárt magminták alapján készült vizsgálatok (Schubert és tsai, 2007) eredményeként elmondható, hogy a Szeghalom dóm metamorf aljzati blokkjának repedésrendszerében egyidőben (azonos hőmérsékleten) eltérő szalinitású víztestek és különböző kémiai összetételű szénhidrogének voltak jelen (M. Tóth és tsai, 2006). Ez más megközelítésből is alátámasztja az amfibolit blokkok kiterjedt, egymással jól kommunikáló repedésrendszerének, valamint a közéjük ékelődő, a rendszer teljes átjárhatóságát korlátozó gneisz domének elszigetelt töréscsoportjainak jelenlétét.

\section{IV.4.1.2 Tektonika, vetök szerepe}

A Tiszai nagyszerkezeti egység Békés-Kodru és Villányi-Bihari öveiben dominánsan K-Ny-i irányultság figyelhető meg az északi vergenciájú eo-alpi (középső-kréta - paleocén) deformációnak köszönhetően (Tari, 1994). A terület jelenleg É-D-i illetve ÉÉK-DDNy-i 
kompresszió alatt áll, majd ez az irány az Alföldön ÉK-DNy-i irányúvá válik. Ez jól egybecseng az aljzat főbb szerkezeti elemeivel, ami kőzetmechanikai szempontból is valószínüsíti azok oldalelmozdulásokkénti ismételt reaktivációját (Bada és tsai, 2007).

A kristályos aljzatban a nagyobb léptékü vetők a medence kialakulásával szinkron extenziós tektonika során alakulhattak ki, majd ezek a jelenleg uralkodó kompressziós feszültségtér irányultságával összhangban reaktiválódva meggyorsíthatják a mélységi fluidum feláramlását a fedő üledékek irányába. Ennek szemléltetésére meredek dőlésü, K-Ny-i csapásirányú aktív vető került beépítésre a Feflow és Modflow modellekbe egyaránt.

A Feflow lehetöséget nyújt 1D és 2D diszkrét alakzatok porózus környezetbe való integrálására, melyekben a Darcy és Hagen-Poiseuille törvények alkalmazhatók a repedésekbeli fluidum-mozgás leírására. A vetőket rendszerint központi magzóna, valamint a fluidum-áramlásban domináns, repedezett kárzóna alkotja. Ez utóbbi vastagságát 20 m-nek definiáltam (Caine és tsai, 1996; Evans és tsai, 1997) a szivárgást pedig Darcy típusúra állítottam, ugyanis a vetőt övező áramlási zóna így jobban közelíthető, mintha egy - egyébként nagyon nehezen becsülhető konstans nyitottság-értékkel jellemzett nyílt, párhuzamos falú repedést tételeztem volna fel.

A szimuláció eredménye, hogy az aljzati kiemelkedésben a túlnyomás hatására kialakuló feláramlás láthatóan felgyorsul a vető mentén (4.21 ábra), az izobárok lehajlanak, a fluidum pedig oldalirányban beáramlik a repedéshálózatból.
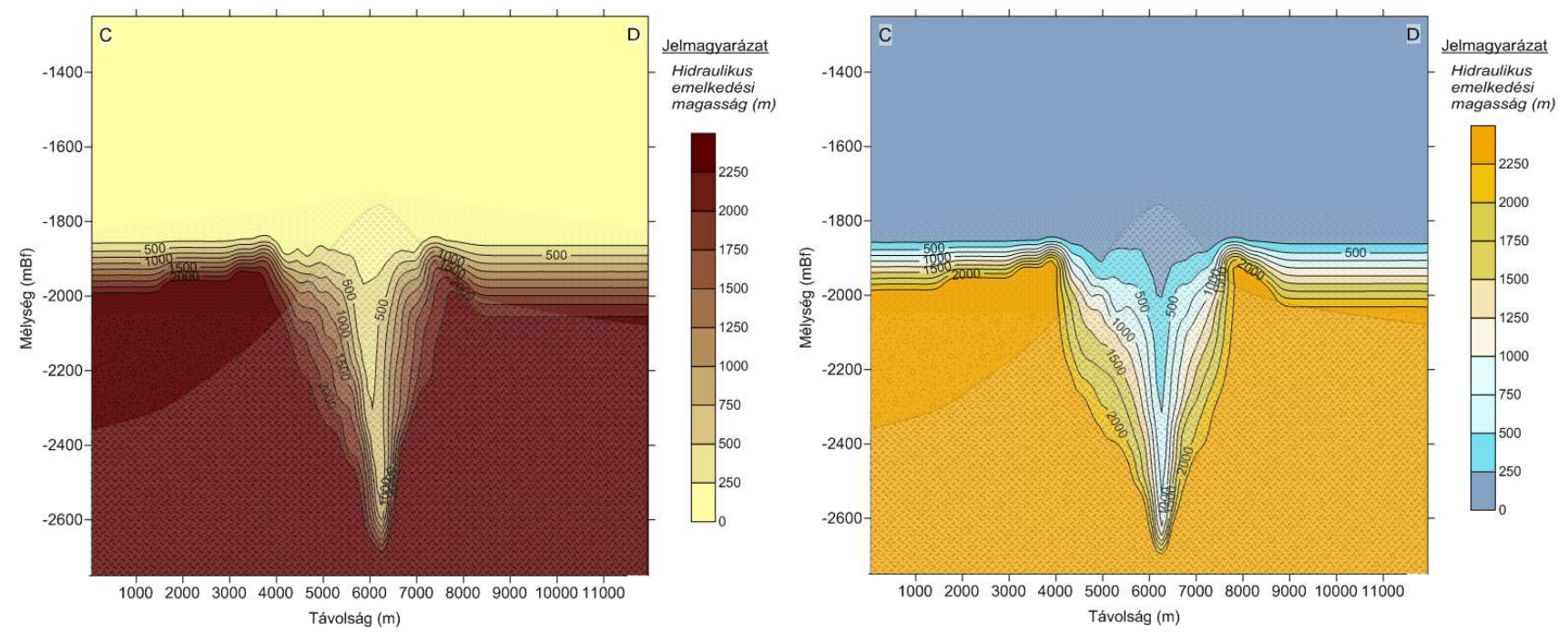

4.21 ábra Modellezett nyomás-anomália a vetőt reprezentáló diszkrét elem mentén (balra: Modflow, jobbra: Feflow),

$$
\mathrm{K}_{\mathrm{vetö}}=0,1 \mathrm{~m} / \mathrm{d} \text { esetén. }
$$

A Modflow-ban ugyan nincs lehetőség diszkrét szerkezetek definiálására, a töréses elemek mégis reprodukálhatók kétféle közelítő módszerrel: az egyik megoldás egy anizotróp porózus közeg 
létrehozása lehet a tektonikai elem mentén, a másik pedig, melyet magam is alkalmaztam, egy magas hidraulikai vezetőképességű zóna kialakításával érhető el a vető helyén.

A zóna mentén, hasonlóan a Feflow diszkrét elemeiben lezajló folyamathoz, a fluidumforgalom megnő, a szivárgási paraméterek javulásával pedig exponenciális ütemben nőni kezd a felfelé szállított víz mennyisége (4.22 ábra). Kellően kiterjedt, széles és permeábilis vetőzóna $\left(\mathrm{A}=20 \mathrm{~m}, \mathrm{~K}_{\text {vetỏ }} \sim 500 \mathrm{mD}\right.$ ) esetén a vízforgalom elérheti az ipari geotermikus hasznosításhoz már elegendő, egy kútra vetített 5000-10000 m³/nap-os tartományt - természetesen ez a mennyiség a vető teljes hosszában értendő.

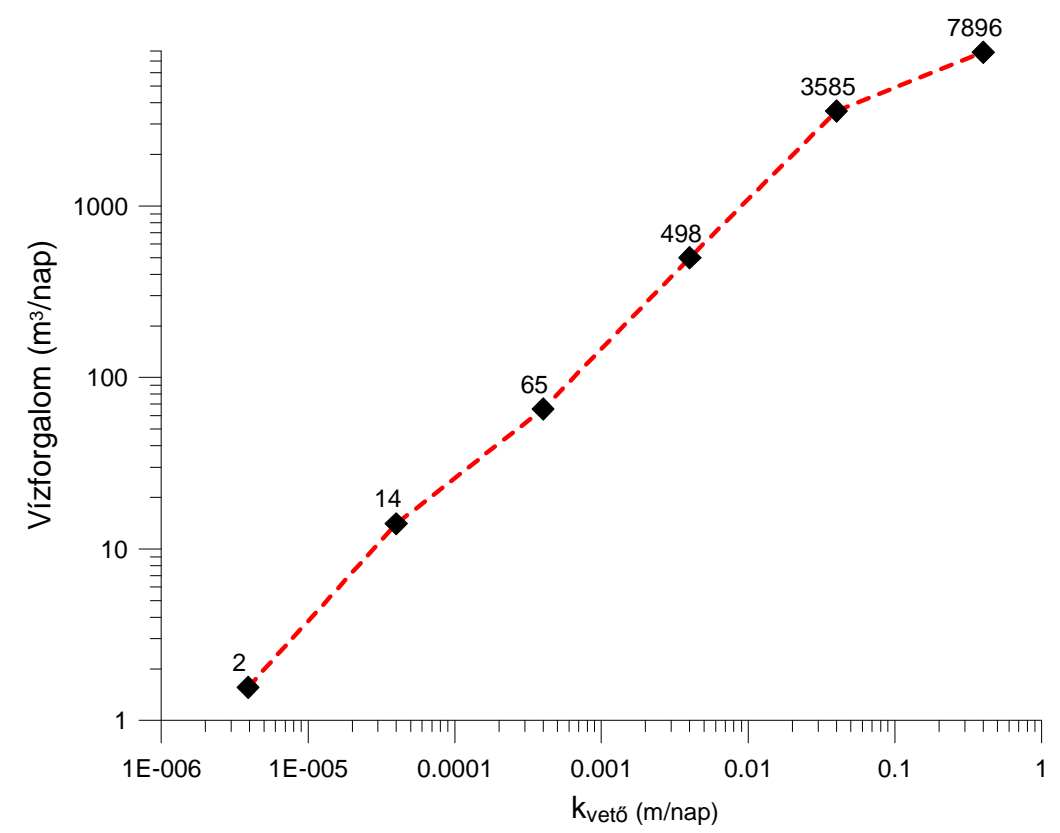

4.22 ábra Függőleges irányú vízforgalom változása a szivárgási tényező függvényében a vetőt reprezentáló, jó hidraulikai vezetőképességű zóna mentén.

\section{IV.4.1.3 Érzékenység vizsgálat-szivárgási tényezö}

A modell megfelelő kalibrációjához nem állt rendelkezésemre elegendő tapasztalati adat, mivel az a csekély számú rövid kútteszt, amit hasonlóan magas nyomású környezetben végeztek, csak igen hiányos és nehezen használható információval szolgálhat (MOL adatbázis).

Az aljzati kristályos kőzetek esetében a hidraulikai paraméterek közül az egyik legnehezebben a szivárgási tényező határozható meg, így az érzékenységvizsgálatot ennek a paraméternek a változására alapoztam.

A K-tényező növelésével az ekvipotenciális kép megváltozik, s ez legmarkánsabban a kristályos hát központi részének tetején érzékelhető. Az ekvipotenciális vonalak itt felfelé tolódnak, felboltozódnak, vagyis a mélyebb részek túlnyomásának hatása a kristályos dóm jobb 
vezetőképessége miatt a sekélyebb részekre is kitolódik, a nyomáskompenzáció vertikálisan nagyobb tartományra terjed ki (4.23 ábra).

Ezzel szemben a vertikális szivárgási tényező csökkentése a potenciál-eloszlásban sokkal kisebb mértékủ változást okoz és a feláramlás lassulását idézi elő.

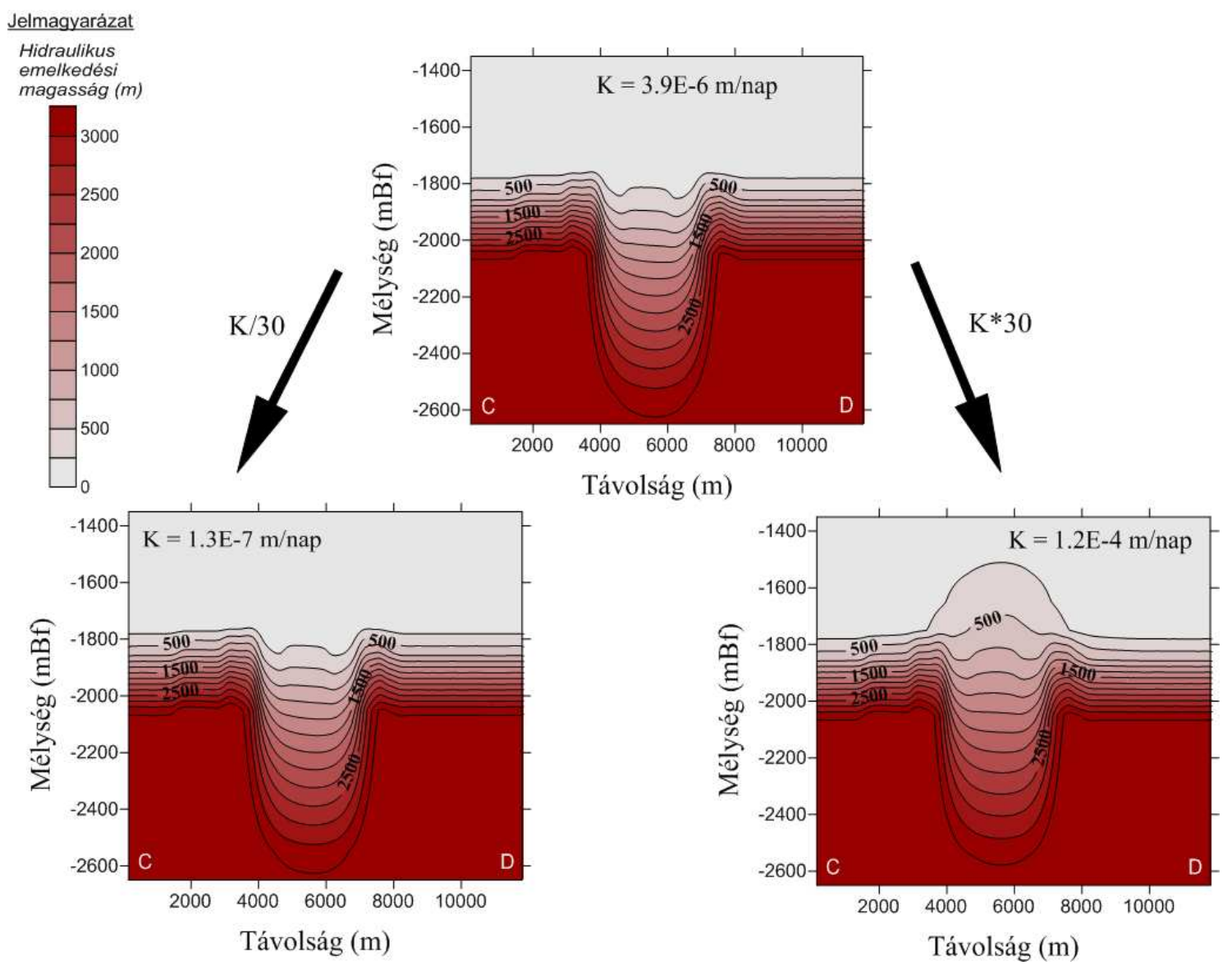

4.23 ábra A szivárgási tényező változásának hatása a potenciál eloszlás alakulására.

\section{IV.4.2 A höterjedés modellezés eredményei}

A kiemelt helyzetü aljzati kristályos hátak és környezetük hőháztartásának kialakulásában mind a konduktív, mind a konvektív hőterjedés szerepet játszik (M. Tóth és tsai, 2007). Azt, hogy a kettő közül melyik jut döntő szerephez, legegyszerübben a Peclét-szám bevezetésével gondolhatjuk végig. A hőtranszport kontextusában a Peclét-szám $\left(P_{e}\right)$ a Reynolds- $\left(R_{e}\right)$ és a Prandtl-számok $\left(P_{r}\right)$ szorzataként áll elö, azaz

$$
P_{e}=R_{e} \cdot P_{r}=\frac{\rho \cdot K \cdot \Delta h}{\mu} \cdot \frac{c_{p} \cdot \mu}{\lambda}=\frac{K \cdot \rho \cdot c_{p} \cdot \Delta h}{\lambda}
$$

ahol $K$ a szivárgási tényező, $\rho$ a víz sürüsége, $c_{p}$ a víz fajlagos hőkapacitása, $\Delta h$ az áramlási csatorna két végén mért hidraulikus emelkedési magasság különbség, $\mu$ a dinamikus viszkozitás, $\lambda$ pedig a 
kőzetre jellemző hővezetőképesség. Bredehoeft és Papadopulos (1965) nyomán, $P_{e}>0,5$ esetekben a konvekciós hőterjedés hatásával is számolni kell, míg ha $P_{e}>1$, a konduktív hővezetés már csak alárendelt szerepet kap.

Ha ezt kivetítjük a vízrekesztő agyagos, márgás üledékek által kitöltött 200 m-es mélységtartományra, akkor $P_{e} \sim 0,8$ körüli értéket kapunk $(F$. melléklet). Modellünkben a fő áramlási csatornaként szolgáló amfibolit vertikális szivárgási tényezője ugyan elég alacsony (mélységgel korrigált $\left.k_{v}=1,8 \cdot 10^{-5} \mathrm{~m} / \mathrm{nap}\right)$, azonban a hidrosztatikus és túlnyomásos rezsim közötti extrém $\Delta h(\sim 2350 \mathrm{~m})$ miatt a hő közvetítésében a felszálló aljzati fluidum is domináns szerepet játszik. E megállapítást a továbbiakban analitikus és numerikus modell-számításokkal is igazolom.

A konduktív hőterjedés és általa létrehozott hőmérsékleti különbségeket a 4.24 ábra alapján gondolhatjuk végig. Ahogy azt a IV.3.5.3 fejezetben láttuk, a -2750 m-es mélységszintben konstans hőáram értéket $\left(q_{-2750}=111,4 \mathrm{~mW} / \mathrm{m}^{2}\right)$ vettem fel a modell teljes területére vonatkoztatva. Ezt azzal a feltétellel tehettük meg, hogy ennél mélyebben a litológia laterális változatosságát elhanyagoltuk, valamint a köpenyből származó hőáramot csakugyan egységesnek vettem a lehatárolt területen belül. A geotermikus gradiens $49,7{ }^{\circ} \mathrm{C} / \mathrm{km}$, a modell felső peremén pedig fix $77,1^{\circ} \mathrm{C}$ a hőmérséklet (ld. IV.3.5.1 fejezet).

Ezekkel az input paraméterekkel, a fluidum-áramlással való hőterjedést egyelőre figyelmen kívül hagyva, a hőmérséklet vertikális eloszlásának kialakulása elsősorban az egyes rétegek vastagságától és hővezetőképességétől függ. Ennek megfelelően a kis hővezetőképességü, finomszemcsés üledékekben (pl. Endrődi Formáció) nagyobb geotermikus gradiens tapasztalható, mint a jobb hővezetési tulajdonságokkal rendelkező magmás és metamorf (pl. gneisz) kőzetekben. A modell központi részén, az aljzati dóm csúcs régiójában, valamint a modell szélén, a mélyebb medencékben számolt geotermikus gradienst a 4.24 ábra szemlélteti. 


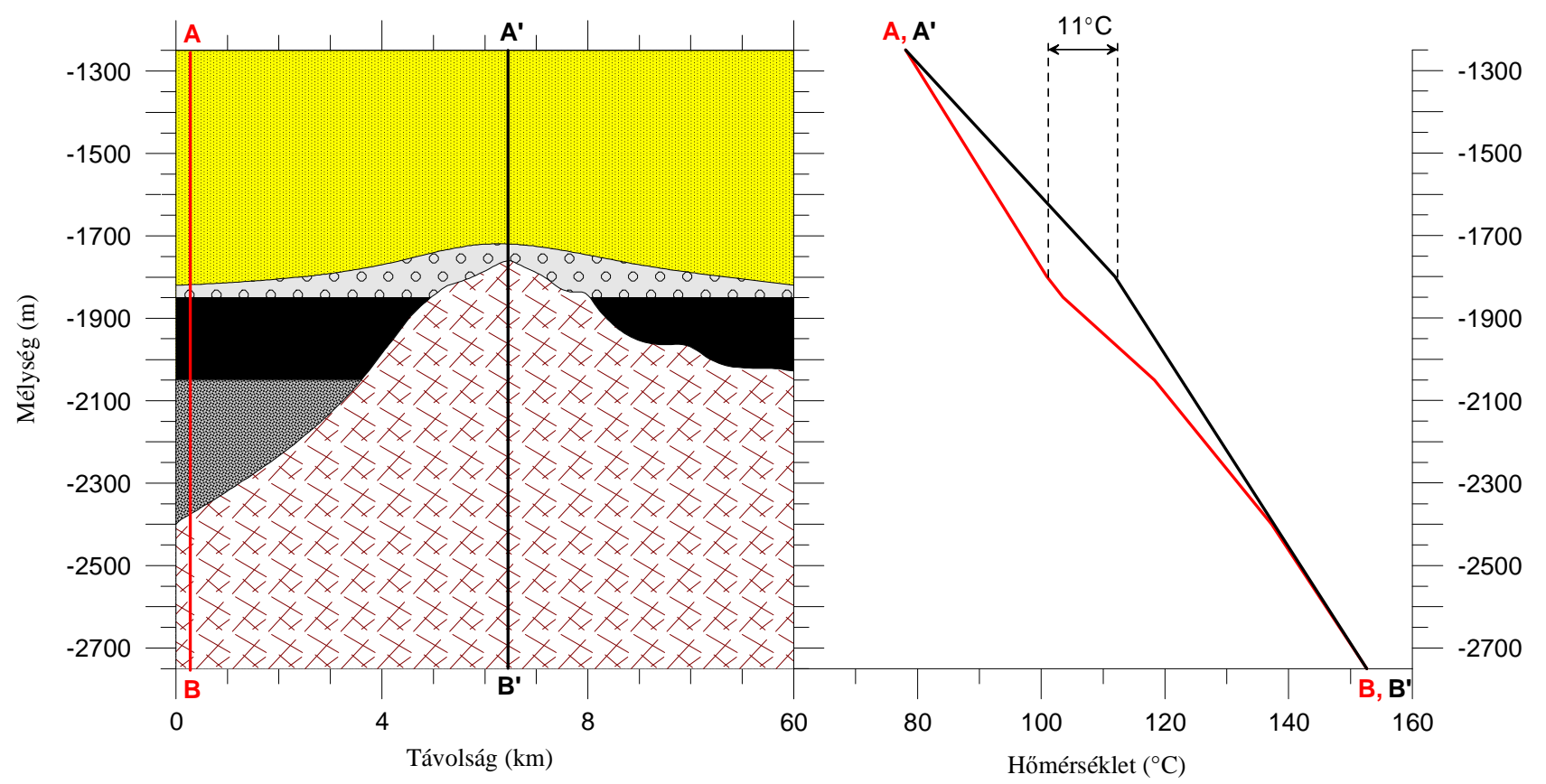

4.24 ábra A geotermikus gradiens alakulása a különböző hővezetőképességü kristályos dóm magjában (A'-B'), illetve a mélyebb, üledékkel kitöltött részeken (A-B).

Az ábrán jól látható, hogy a kristályos komplexumból kilépve, az A-B vonal alsó részén a hőmérsékleti gradiens ugrásszerủen megnő, majd ez tovább fokozódik a (-1850) - (-2050) m közötti szakaszon, a többnyire márga-agyagmárga típusú üledékek alacsony hővezetőképességének köszönhetően. Ezzel szemben az aljzati dóm tengelyében, a magasabbra nyúló jó hővezető kristályos kőzettömeg és a szigetelö fedőüledékek hiánya miatt a konduktív hővezetés pozitív hőanomáliát okoz a kristályos aljzati magaslat csúcs régiójában. Ennek mértéke kb. plusz $10{ }^{\circ} \mathrm{C}$ az üledékkel fedett medencebeli területek hasonló mélységszintjéhez képest. Az aljzattól távolodva a sekélyebb zónák felé, ott ahol a kristályos hát fütő hatása már nem érvényesül (-1700 - -1750 m), az A-B és A'-B' szakaszok gradiensei összeolvadnak. Ez a hatás jól visszatükröződik az egyes mélységszintek hőmérsékleti térképein (Lorberer és tsai, 2004), a kristályos vonulat közelsége általában pozitív hőmérsékleti anomáliát rajzol ki.

A Feflow numerikus szimulátorral elvégzett hőtranszport modell kezdeti hőmérsékleti értékeit, azaz a számítás kiindulásához szükséges input hőmérsékleti mezőt, a kutatási terület fúrásaiból (Deva-1, Deva-2, En-2, Gyo-1, Sark-35, Sark-36, Szr-4, Sz-2) ismert geotermikus gradiensek átlagolt konstans értéke alapján számoltam, a hőáram és hővezetési tényezők figyelembe vételével, tehát a konduktív - és természetesen a konvektív - hőterjedés hatása a kiindulási állapotban még nincs jelen. A numerikus hőtranszport modell futtatásával a konduktív és konvektív hőszállítás együttes hatása látható. A tisztán konvektív folyamatok által okozott 
hőmérsékleteloszlásbeli különbségek végül a konduktív számítások ismeretében már egyszerü matematikai művelettel leválaszthatók.

A hőtranszport szimuláció a szivárgási részhez hasonlóan permanens esetet ábrázol, vagyis a hőtranszport egyenletek iteratív megoldása a számítási háló egyes elemei között addig történik, míg a peremfeltételeknek megfelelően be nem áll az egyensúly. Ezt a valóságot jellemző állapotot tükrözi a 4.25 ábra.

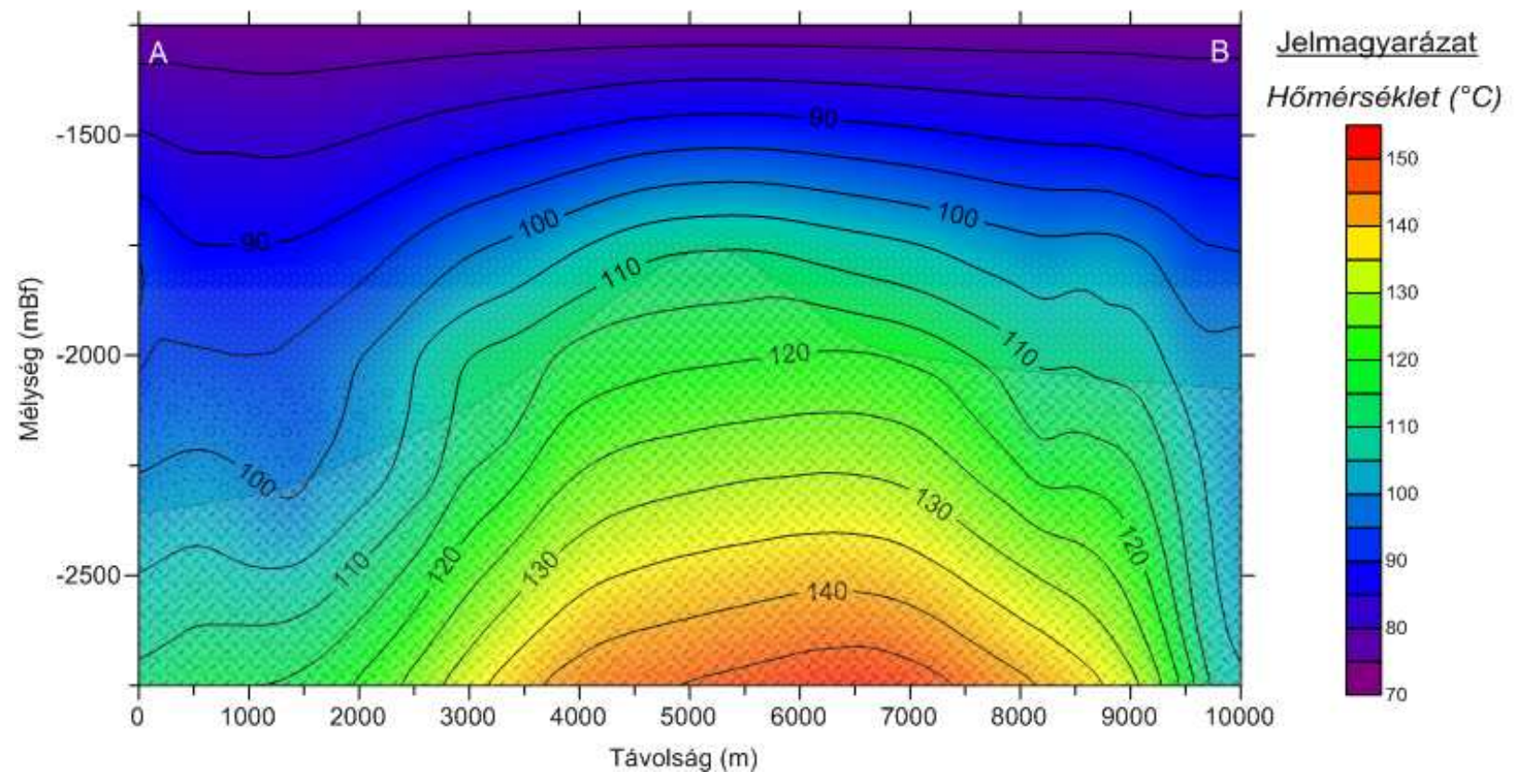

4.25 ábra Az aljzati magaslat és környezetében számított hőmérsékleti mező keresztmetszeti képe

(A-B szelvény, ld. következő ábra).

A hőmérsékleti képen jól látszik, hogy az izotermák nem egyenesen futnak, hanem a modell középső részén felfelé tolódnak, vagyis ebben a régióban, adott mélységszintben melegebb lesz, mint a modell szélein. Ez egyrészt a magmás-metamorf komplexumot felépítő kőzetanyag magasabb hővezetési tényezőjéből fakad (konduktív elem), másrészt az itt tapasztalható túlnyomás miatt a feláramló forró fluidum által szállított hő tehető felelőssé a jelenségért.

A modell szélei és tengelye között horizontálisan enyhén csökken a különbség, ahogy felfelé haladunk. A -1850 m és -2050 m közötti 200 m-es mélységtartományban még magas, $220^{\circ} \mathrm{C}$ az anomália, ennél sekélyebben azonban hirtelen lecsökken ez a differencia. Ezt a 15. modellréteg vízszintes szelvényén követhetjük nyomon (4.26-4.27 ábra). 


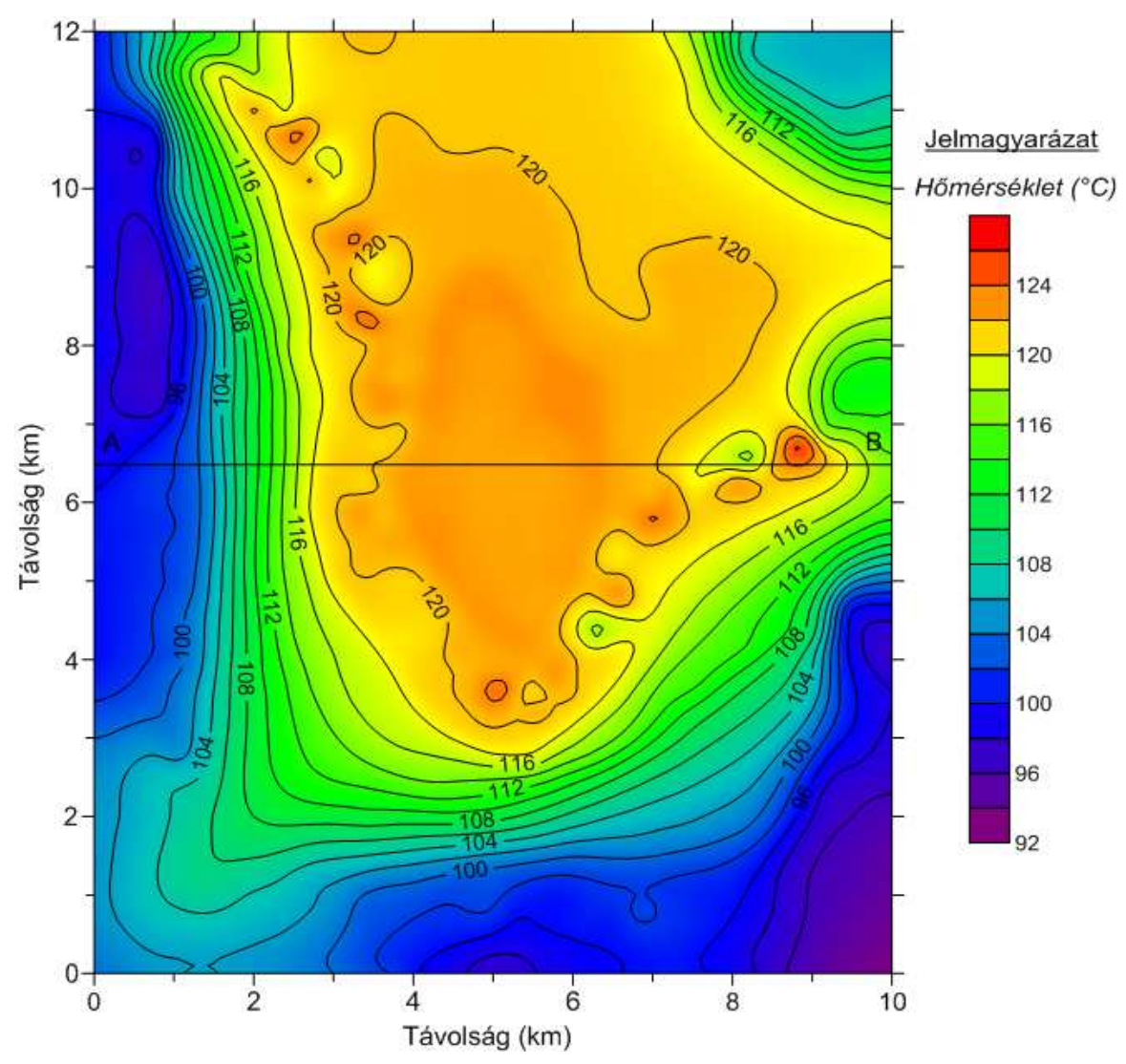

4.26 ábra A hőtranszport szimulációval számított hőmérsékleti eloszlás a 15. modellrétegben.

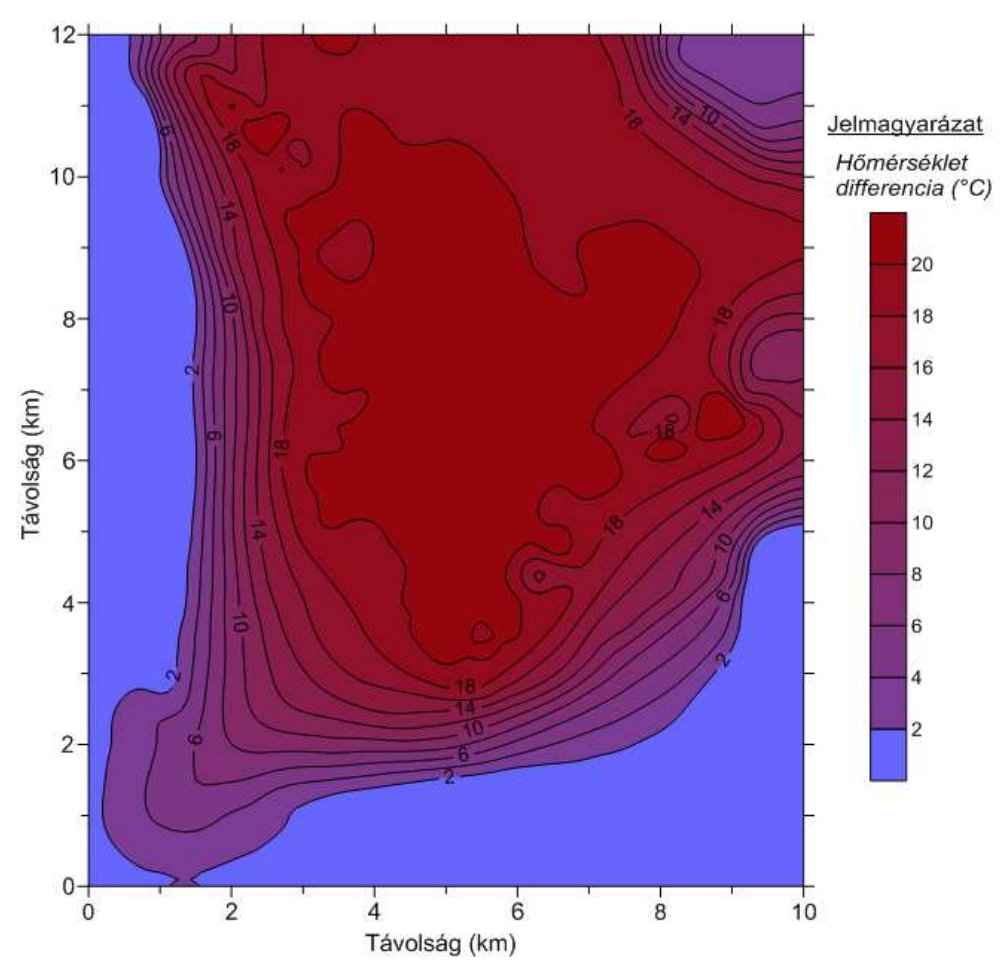

4.27 ábra A kezdeti és a hőtranszport szimulációval számított hőmérsékleti eloszlás különbsége a 15. modellrétegben. 
A maximális hőanomália a hidraulikai "kémény" középpontjában jelentkezik, mértéke megközelíti a $20{ }^{\circ} \mathrm{C}$-ot. Utalva a korábbi számításra (4.24 ábra), miszerint a konduktív hővezetés által okozott hőtöbblet ugyanitt kb. $10{ }^{\circ} \mathrm{C}$-ot tett ki, beláthatjuk, hogy a hőterjedés konvektív összetevője is hasonló mértékü, 8-10 ${ }^{\circ} \mathrm{C}$-os pozitív hőanomáliát okoz. Mindezt alátámasztja a Peclét-számra meghatározott 0,8 körüli érték is, miszerint a konvekciós hőterjedés hatásával már számolni kell $\left(P_{e}>0,5\right)$, de még nem tulajdoníthatunk neki egyértelmüen vezető szerepet $\left(P_{e}>1\right)$. Meg kell jegyezni, hogy az Alföld területén sok helyen tapasztalható viszonylag kisebb, 20-50\%-os túlnyomás esetén - a kristályos komplexum rossz szivárgási tulajdonságai miatt - a konvektív hatás háttérbe szorulására lehet számítani.

Ez a pozitív hőmérsékleti anomália kissé tompítva ugyan, de megmarad az aljzati kiemelkedés központi része feletti üledékekben is (4.28-4.29 ábra), ami geotermikus energiakutatási szempontból potenciális helyszíneket jelenthet, amennyiben a hidrodinamikai paraméterek is kedvezően alakulnak. A hatás vertikálisan pár száz méterig még nyomon követhető, a Szolnoki Formáció felső részében már elhanyagolható jelentőségü.

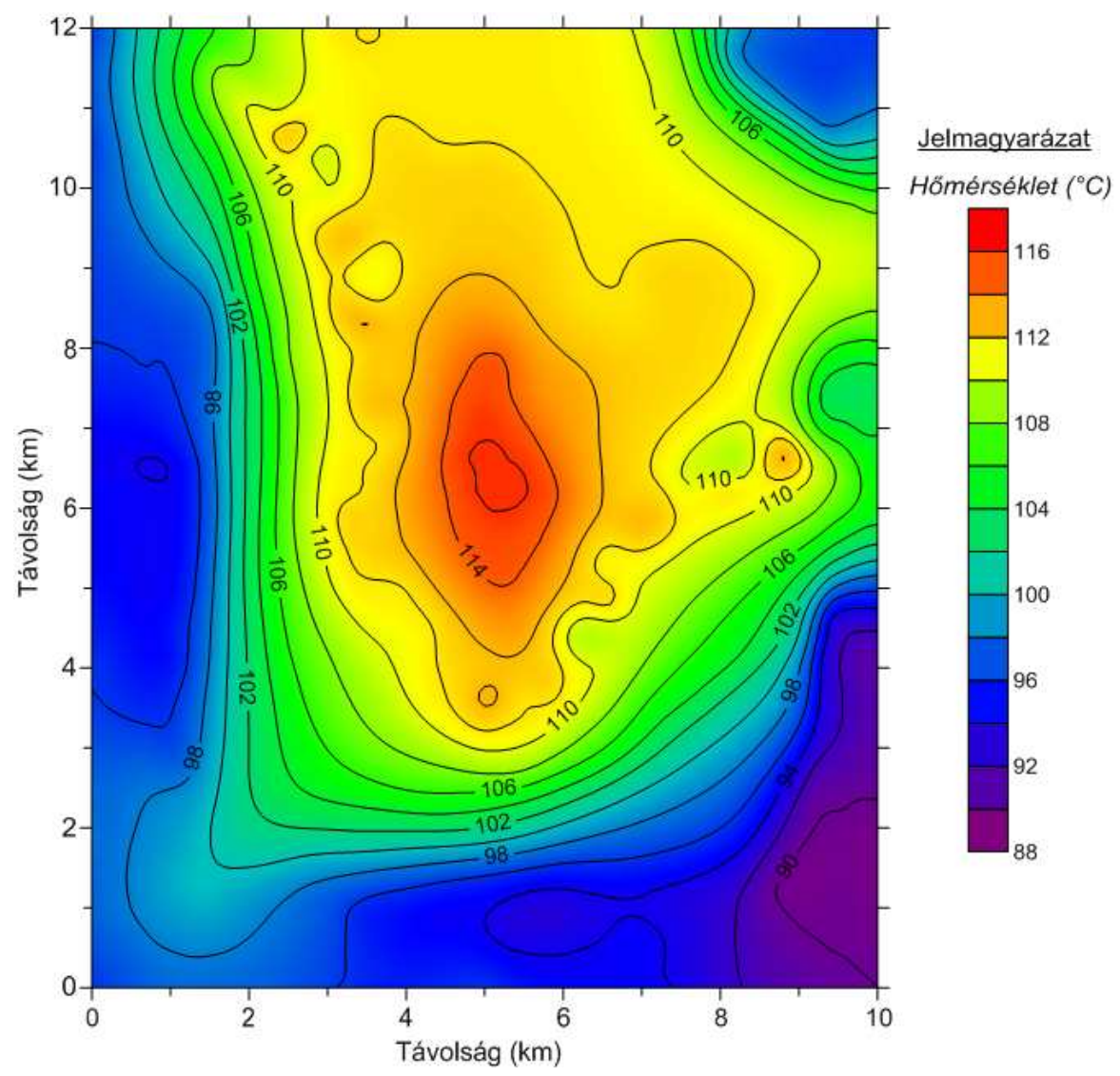

4.28 ábra A hőtranszport szimulációval számított hőmérsékleti eloszlás az aljzat felett, a 12. modellrétegben. 


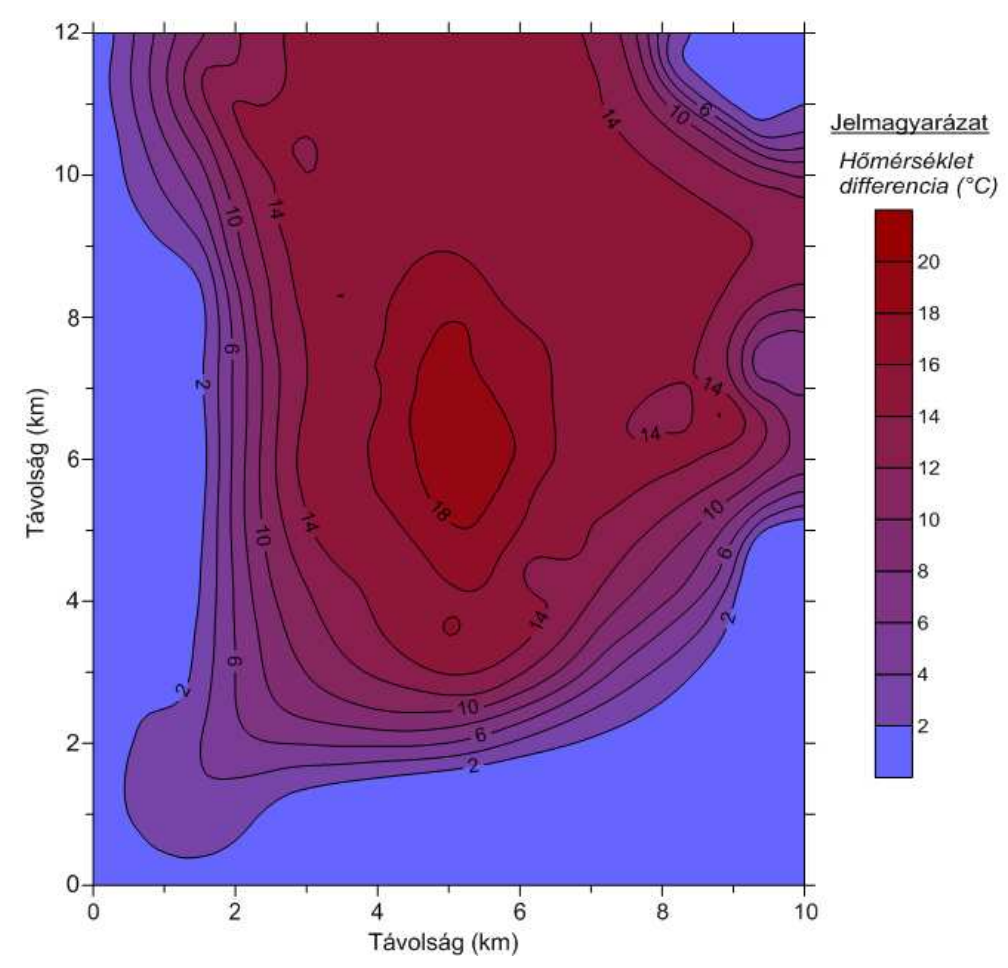

4.29 ábra A kezdeti és a hőtranszport szimulációval számított hőmérsékleti eloszlás különbsége a 12. modellrétegben.

A hidrodinamikai és hőtranszport modellezés eredményeit figyelembe véve láthatjuk, hogy a repedezett metamorf aljzatban a komplex litológiának és szerkezeti fejlődésnek köszönhetően egy megosztott áramlási rendszer alakul ki. Amíg a gneisz töréshálózata főként egymástól elszigetelt csoportokat tartalmaz, addig az amfibolit típusú zónák jóval a perkolációs küszöb fölött helyezkednek el, föszerepet vállalva így az áramlási tér kialakításában.

Régóta ismert, hogy regionális földtani okok miatt a Pannon-medence mélyebb üledékes részmedencéiben sok helyen magas túlnyomás alakul ki. A numerikus modell azt szemlélteti, hogy bizonyos geológiai szituációkban a metamorf kőzetegyüttes rossz szivárgási tulajdonságai ellenére a fluidum beszivárog és felfelé migrál a nyomáskompenzáció által létrehozott hidrodinamikai „kéményen” keresztül. A magaslatok fölött az áramlási rendszer viselkedése nagyban függ a gravitációs rendszer karakterisztikájától a medence magasabb részein. Mindemellett a kapcsolt konvektív és konduktív hőterjedés, melyek közel azonos szerepet vállalnak, pozitív hőmérsékleti anomáliát okoz a magaslatok csúcsán. Ez számításaim szerint $\sim 20^{\circ} \mathrm{C}$ körül alakul, s hatása még vertikálisan pár száz méterig nyomon követhető a fedő üledékekben. Adott földtani körülmények között tehát ezek a zónák geotermikus energia-kutatás szempontjából is figyelmet érdemelnek. 


\section{IV.5. A numerikus medellek összehasonlító értékelése}

Véges differencia típusú hőtranszport modellezést nem végeztem, így a Feflow és Processing Modflow rendszerek csak fluidum-áramlás szimuláció terén kerülnek összevetésre. A fő különbség tapasztalataim szerint abban rejlik, hogy a végeselemes rendszerben sokkal rugalmasabb, pontosabb modellvázat lehet építeni, ami a végeselemes háló kedvező tulajdonságai miatt jobban közelíti a valós morfológiát. A modell szerkezet utólagos módosítása, kisebb igazítások csakugyan könnyebben elvégezhetők a Feflow-val, a kitüntetett szerepü elemek, mint kutak, diszkrét törések, stb. körüli felbontás növelés itt kisebb számításigénnyel, koncentráltan megoldható. A véges differenciás rendszerben ezzel szemben egy utólagos módosítás sokszor nem hajtható végre a modell újraépítésének igénye nélkül, a hálósürítés pedig óhatatlanul számos feleslegesen generált cellát is eredményez.

Ami a diszkrét elemek (vetők, repedések) kezelését illeti, azok beépítése a Modflow rendszerbe egyértelmüen nehézkes, mind a geometria leképezése, mind a hidrodinamikai paraméterek kiosztása terén egyszerüsítésekre van szükség. Mindez a Feflow-ban - az 5.4 verzió és az felett - különálló modulként adva van, habár a diszkrét elemek dőlése itt is csak korlátozottan definiálható, és a törésparaméterek statisztikai eloszlásokon alapuló parametrizálása sem teljesen lehetséges.

A szimuláció utáni 2D és 3D megjelenítésben a Feflow több lehetőséget nyújt, bár az adatok exportálása terén néhány praktikus opció még megkönnyítené a további elemzéseket.

Az előbb felvázolt tulajdonságokkal szemben a REV méret jobban értelmezhető a véges differencia rendszer szabályos rácshálójában, ezáltal a hidraulikai paraméterek homogenizálása is közelebb áll a valósághoz.

Geotermikus rezervoárok esetén a Feflow megoldást nyújt a hidrodinamikai paraméterek hőmérséklet okozta változásának modellezésére is. Ennek hiányában ügyelni kell a szivárgási tényezők kiosztására, mert a viszkozitás és sürüségbeli különbségek akár 4-5-szörös eltérést is okozhatnak már 2000-2500 m mélységben.

A vízrészecskék nyomvonalainak és az elérési idők vizsgálata terén a Modfow bizonyult használhatóbbnak, a Feflow-ban igen nehézkes a rétegek között terjedő áramlási pályák lekövetése és megjelenítése.

Az eredmények kiértékelésére és az utólagos elemzések elvégzésére mindkét rendszerben széleskörü a lehetőségek tárháza, az adatok kimentése viszonylag egyszerü és logikus. 
Mindezt összevetve, eddigi tapasztalataim alapján a véges elemes módszereket valamivel alkalmasabbnak tartom a témához hasonlóan komplex hidrodinamikai és hőtranszport jelenségek modellezésére, hivatkozva a fentebb részletezett pozitívumokra. 


\section{Összefoglalás}

A kutatásom fő célja az Alföld kristályos aljzatának kiemelt helyzetü blokkjaiban, illetve az aljzat és az üledékes fedő képződmények között lejátszódó hidrodinamikai és hőtranszport folyamatok megismerése volt, melyet komplex repedéshálózat vizsgálati módszer és numerikus modellezési séma alapján végeztem el.

A repedezett rezervoárok hidrodinamikai szempontból egyik leglényegesebb tulajdonsága a diszkrét töréses elemek összekapcsolódási struktúrájában rejlik. Ez a tulajdonság gyakorlatilag az egymást metsző törések részarányaként számszerüsíthető, melyet alapvetően a repedéshálózat geometriai paraméterei határoznak meg. A három legfontosabb független változó, mely adott törésrendszer valósághü leírásához elengedhetetlen, a hosszúságeloszlás $E$ hatványkitevője, a $D$ fraktál dimenzió és az $\alpha$ relatív dőlés. Mivel az összefüggő, perkolációs klaszterek nagyságának kifejezésére nem létezik explicit $f(E, D, \alpha)$ formula, a cél érdekében e helyett az $E-D, E-\alpha$ és $D-\alpha$ változósíkok nomogram sorozatát készítettem el. Az E-D- $\alpha$ tér kétdimenziós metszetein a repedéshálózatoknak három altípusa különíthető el.

Az első típus esetében, kis paraméter értékeknél az összefüggő rendszerek mérete szinte elhanyagolható, az összes repedésnek mindössze kis hányada metszi egymást. Ezzel szemben a második típusnál, nagy paraméter értékek esetén a törések jelentős része egy összefüggő hálózatba tömörül. E két típus szimulációja igen megbízható eredményt ad, a különböző realizációk eredményei alapvetően megegyeznek, a szórás alacsony marad. Ezek a repedésrendszer típusok továbbá kevésbé érzékenyek a mérési pontatlanságokra és a paraméterek meghatározása során fellépő bizonytalanságokra. A harmadik típusnál a repedésrendszer nagyon érzékenyen viselkedik a bemenő paraméterek változására, s egyúttal megjósolhatatlanná válik a perkolációs klaszterek relatív mérete.

A vizsgált alföldi, metamorf szénhidrogén tárolók esetén az eredmények azt mutatják, hogy az aljzati heterogén kőzettest hidrodinamikai jellege litológiai kontroll alatt van. Míg a kvázi impermeábilis gneisz domének jóval a perkolációs küszöb alatt helyezkednek el, addig az amfibolit zónák kiterjedt, összefüggő repedéshálózattal rendelkeznek. A gneisz extrém alacsony porozitással és közelítőleg 70 m-es élhosszúságú REV-vel, az amfibolit egy nagyságrenddel nagyobb hézagtérfogattal (2\%) és jóval kisebb REV élhossz-mérettel ( 20 m) jellemezhető.

Kihasználva azt, hogy a repedezett rezervoárok bizonyos mérettartomány felett ekvivalens kontinuumként kezelhetők, a perkolációs számítások mellett a reprezentatív elemi térfogat származtatása is hasonlóan fontos szerepet kap a hidrodinamikai modellezésnél. A REV pontos 
meghatározása a repedéshálózat geometriai alapparamétereinek függvényében lehetséges. A számítások azt mutatják, hogy a REV görbe monoton csökkenő, tehát egyre kisebb értékek jellemzik a töréshosszúság és -sürüség növekedésével.

A repedéshálózatról a perkolációs klaszterek méretének meghatározásával és a REV elemzéssel nyert információkat ekvivalens kontinuum modellbe építettem be a hidrodinamikai és hőtranszport számítások bemeneti paramétereiként. A folyamat egészét tekintve valójában egy hibrid típusú modellezés valósult meg a diszkrét repedések és homogenizált áramlási tér összekapcsolásával, ahol a számszerüsítésnek három fő mozzanatát kell kiemelni. Először is a DFN szimulátorral számolt permeabilitás tenzort konvertáltam horizontális és vertikális szivárgási tényezőkké. Ezt követte a REV vizsgálat a DFN szimulátorral számolt porozitás alapján, majd a REV megfeleltetése, mint homogén cellaméret. Végül a perkolációs vizsgálat és az effektív porozitás becslése történt meg az összefüggő és nem összefüggő repedéscsoportok alapján. Az egységesített repedésparamétereknek, valamint a porózus kőzetek paramétereinek importálása ezen túlmenően a szokásos módon zajlott.

Az ily módon parametrizált numerikus modell olyan több területről is ismert geológiai szituációt mutat be, ahol az aljzati magaslat kiemeltebb részein kivékonyodtak, vagy hiányoznak a fedő impermeábilis rétegek. A hidrodinamikai modellezés eredményei azt mutatják, hogy ezeken a területeken a hidraulikai kapcsolat kialakul a mélyebb túlnyomásos és a sekélyebb gravitációs áramlási rendszerek között. A kristályos komplexum lejtőjén felhalmozódott durvatörmelékes kőzetekből beszivárog a fluidum a jóval alacsonyabb vezetőképességgel rendelkező aljzati töréshálózatba, s a repedezett tárolón keresztül kompenzálódik a felhalmozódott túlnyomás. A felfelé tartó fluidum az alsó-pannóniai homokkövekben már a túlnyomás kiegyenlítődésével mérsékeltebb ütemben szivárog, idővel bekapcsolódik és keveredik a gravitációs áramlási rendszerekben mozgó vizekkel.

Kapcsolt hőterjedés modellezéssel illusztráltam a kiemelt helyzetű kristályos hátak és környezetük hőháztartásának kialakulási folyamatát. Az eredmények alapján, melyeket analitikus számításokkal is ellenőriztem, mind a konduktív, mind a konvektív hőterjedés közel azonos szerepet játszik. A maximális hőanomália a hidraulikai "kémény" középpontjában jelentkezik, mértéke megközelíti a $20{ }^{\circ} \mathrm{C}$-ot. Ez a pozitív hőmérsékleti anomália észlelhető az aljzati kiemelkedés központi része feletti üledékekben is, növelve ezzel e helyszíneknek a geotermikus jelentőségét. 


\section{Summary}

The main objective of the exploration was to study the hydrodynamic and heat transport processes between the uplifted basement blocks and overlying sediments in the Hungarian Great Plain, which was performed by a complex fracture network analysis method and numerical modelling scheme.

One of the most essential parameters of the hydrodynamic behaviour of fractured reservoirs is the interconnectivity of the discrete fractures. This feature can be measured as the proportion of the interconnected fractures that basically depends on the geometric parameters of the fracture network. The three most important independent variables that are essential in describing the fracture network on a realistic way are the following: exponent $E$ of the length distribution, fractal dimension $D$ and relative dip $\alpha$. A series of $E-D, E-\alpha$, and $D-\alpha$ nomograms were computed as there is no way to calculate the percolation cluster size through any explicit $f(E, D, \alpha)$ formula. Fracture networks tend to exhibit three different subtypes on these two-dimensional sections of the $E-D-\alpha$ variable space.

In the first class the sizes of the interconnected fracture clusters are negligible, while the majority of the fractures are joined in case of the second type, creating a mutually interconnected system. Simulations result in very stable outputs with low standard deviation in both subtypes. These fracture networks are less sensitive to uncertainties from parameter recording; measurement errors do not influence significantly the final result of the model. In case of the third subtype, however, not only the fracture system tends to be the most sensitive to measurement errors of the input parameters, but it is also impossible to predict the size of the interconnected clusters due to the high standard deviation.

In case of the investigated metamorphic hydrocarbon reservoirs in the Hungarian Great Plain, the results show that the hydrodynamic behaviour of the heterogeneous rock body is under lithological control. The amphibolite zones have intensively fractured, connected network, while the quasi-impermeable gneiss domains are far below the percolation threshold. The gneiss can be characterized by extremely low porosity and approximately $70 \mathrm{~m}$ REV size, the amphibolite has an order of magnitude higher porosity and far lower REV size $(\sim 20 \mathrm{~m})$.

Given that a fractured reservoir acts as an equivalent continuum above some scale, REV plays an essential role in hydrodynamic modelling studies. Accurate estimation of REV size is possible as a function of the basic geometric parameters of the fracture network. Calculations suggest that the REV curve is monotonously decreasing, taking successively smaller and smaller values with the increase of $E$ and $D$. 
The acquired information from determining the relative size of the percolation clusters and performing REV calculations was built into an equivalent continuum model as the input parameters of the hydrodynamic and heat transport calculations.

A hybrid type modelling was performed in such a way regarding the whole process with connecting the discrete fractures and the homogenized flow field - three main steps should be underlined during quantification. At first the permeability tensor calculated by the DFN simulator was converted to horizontal and vertical hydraulic conductivity values. Secondly REV analysis was carried out based on the porosity calculated by the DFN simulator, and then REV was assigned as homogeneous cell size. Finally the percolation analysis and estimation of the effective porosity were performed based on the connected and not connected fracture groups. The import of the unified fracture parameters and the parameters of the porous rocks was happened on a common way beyond that.

The numerical model introduces such a geological situation known from several locations, where the overlying impermeable layers have been thinned out or absent at the most uplifted parts of the basement high.

The results of the hydrodynamic model show that hydraulic connection exists between the deeper overpressured and the shallower gravitational flow systems in these areas. The fluid flow into the lower permeability fracture network of the basement from the coarse grained sediments accumulated on the slope of the crystalline complex and the overpressure can be compensated through the fractured reservoir. The upflowing fluid then moves moderately in the lower pannonian sandstones and mix with the water stored in the gravitational flow system.

The coupled heat transport model illustrates how the heat distribution develops in the centre and in the vicinity of the uplifted basement highs. The result - checked by analytic calculations as well - show that conductive and convective heat flows have both similar effects. The maximum heat anomaly is approximately $20{ }^{\circ} \mathrm{C}$ appearing in the centre of the hydraulic „chimney”. This positive effect can also be observed in the overlying sediments, giving more significance and attention to geothermal energy. 


\section{Eredmények tézisszerü összefoglalása}

1., A repedéshálózatok - fluidum-átjárhatóság szempontjából kritikus - perkolációs viszonyai meghatározhatók a legfontosabb geometriai törésparaméterek, mint repedéshosszúság eloszlás, repedésorientáció és repedéssürüség alapján. Az említett geometriai paraméterek és a repedéshálózat összefüggősége közötti matematikai kapcsolat explicit függvénnyel nem írható le. A kapcsolat meghatározására egy DFN modellezési módszer felhasználásával olyan nomogram sorozatot készítettem, amely segítségével bármely ismert paraméterekkel rendelkező töréshálózat perkolációs jellemzői meghatározhatók.

2., A nomogramok segítségével az egyes kőzettípusokra jellemző repedéshálózatokat $E-D-\alpha$ ( $E$ : hosszúságeloszlás hatványkitevője, $D$ : fraktál dimenzió, $\alpha$ : relatív dőlés) paramétereik alapján 3 fö perkolációs csoportba soroltam. Az első típus esetében, alacsony paraméter értékeknél az összefüggő rendszerek mérete elenyésző, az összes repedésnek csak maximum 10 százaléka alkot kommunikáló hálózatot. A második esetben, magas paraméter értékeknél a törések több mint 80 százaléka összefüggő hálózatot alkot. Mindezekkel ellentétes tulajdonságú a középső zóna jellemző töréshálózata, ahol az összefüggő rendszer mérete lényegében nem megjósolható. Ez a rendszer reagál legérzékenyebben az alapparaméterek mérési bizonytalanságaira is.

A második legnagyobb egymással kommunikáló törésekből álló csoport az input paraméterek ( $E, D$ és $\alpha$ ) értékeitől függően akkor éri el maximumát, ha a szóban forgó repedéscsoport a perkolációs küszöb környezetébe esik - ez alatt és felett a kimaradó törésekből összeálló csoportok mérete a paraméterek növekedésével egyre jobban elmarad a legnagyobb klaszter méretétől.

3., Adott E-D- $\alpha$ paraméterhármassal rendelkező töréshálózat reprezentatív elemi térfogatának meghatározására modellezési eljárást dolgoztam ki. A módszer lényege, hogy ezen paramétereket meghatározott intervallumon változtatva, minden paraméterhármas esetén azonosan valószínü porozitás értékeket generálunk egyre növekvő felbontású rácshálók esetén. Ezután a porozitások átlagát és szórását feljegyezve, a variációs koefficiens számításával határozzuk meg a reprezentatív elemi térfogatot.

4., A Pannon-medence kristályos aljzati kiemelkedései és neogén fedőképződményei között lejátszódó fluidum-áramlási és hőtranszport folyamatok vizsgálatára modellezési módszert 
dolgoztam ki. A módszer lényege, hogy a numerikus modell struktúrájába szisztematikusan beépítjük a repedezett kőzettestről nyert információkat. Először a repedezett kőzettest egyedi töréseinek és töréshálózatának legfontosabb paramétereit (repedéssürüség, töréshosszúság-, nyitottság eloszlás, orientáció) adjuk be egy DFN szimulátorba, majd a sztochasztikusan generált töréshálózatokon további hidrodinamikai paramétereket számítunk (porozitást és permeabilitás), ezen kívül REV és perkolációs vizsgálatot végzünk. Ezek az információk végül egy ekvivalens kontinuum modellben fognak szerepelni a hidrodinamikai és hőtranszport számítások bemeneti paramétereiként. Az folyamat egészét tekintve valójában egy hibrid típusú modellezés valósul meg a diszkrét repedések és homogenizált áramlási tér összekapcsolásával, ahol a számszerüsítés a következőképpen zajlik:

- DFN szimulátorral számolt permeabilitás tenzor konvertálása horizontális és vertikális szivárgási tényezőkké;

- REV vizsgálat elvégzése a DFN szimulátorral számolt porozitás alapján, REV megfeleltetése, mint homogén cellaméret;

- perkolációs vizsgálat elvégzése a DFN szimulátor használatával, majd az összefüggő és nem összefüggő repedéscsoportokból effektív porozitás becslése.

5., Az Alföld egyes kiemelt helyzetben lévő aljzati kőzetblokkjaiban jelentős mennyiségü fluidum van jelen, melynek eredete eddig nem teljesen tisztázott. A disszertációmban részletezett numerikus modellezés a preneogén repedezett tárolók feltöltődési mechanizmusát mutatja be. Számításaim szerint a helyenként észlelhető extrém túlnyomás ellenére az aljzati magaslatok fluidum utánpótlása mindvégig biztosított a lejtőre települő fiatalabb üledékes képződmények felől. Ez az áramlási pálya magyarázatot ad az aljzati képződmények szénhidrogén tárolóvá válásáról, illetve igazolja a geotermikus energia kutatás szempontjából értékesnek nyilvánítható speciális területek jelenlétét.

6., A hidrodinamikai modell bizonyítékkal szolgál arra, hogy a túlnyomásos aljzati magaslatokba oldalirányból beszivárgó fluidum felfelé továbbáramlik a pannóniai üledékes kőzetekbe, ahol az aljzati komplexumok teteje felett jellemzően szétseprüződő nyomvonalak mentén vagy közvetlenül a sekély gravitációs vízáramlási rendszerek regionális megcsapolási zónáit táplálja, vagy azok beszivárgási pályái által eltérítve folytatja útját a felszín felé.

7., Az 5. és 6. pontban említett folyamatok geotermikus vonatkozásának ismertetésére numerikus hidrodinamikai és hőtranszport modellt készítettem. A szimuláció eredménye arra szolgáltat 
bizonyítékot, hogy a geotermikus és hidrogeológiai folyamatok az aljzati kristályos magaslatok csúcsának környezetében pozitív hőanomáliát indukálnak. A modellezett területen, az üledékes fedőképződmények alsó szakaszán ennek értéke kb. $20^{\circ} \mathrm{C}$, mely hatás felfelé fokozatosan csökken és a magaslatok felett mintegy 2-300 méterrel gyakorlatilag megszűnik, kiegyenlítődik.

8., A túlnyomásos aljzati magaslatok csúcsán, ahol az üledékes impermeábilis fedőképződmények hiányoznak, a központi zóna feletti üledékekben jelentkező pozitív hőmérsékleti anomália kialakulásában mind a konduktív, mind a konvektív hőterjedés szerepet játszik. A két tényező egyéni hatására analitikus és numerikus számításokkal következtettem, amit a Peclét-szám meghatározásával is sikerült alátámasztani. Eszerint a konduktív és konvektív hőterjedés közel egyforma hatást fejt ki a vizsgált földtani-hidrodinamikai rendszerben, ami nagyrészt az extrém aljzati túlnyomásnak köszönhető. 


\section{Irodalomjegyzék}

Ahmed, S. E. (2002). Simultaneous estimation of coefficients of variation. Journal of Statistical Planning and Inference, 104, p. 31-51.

Almási, I. (2001). Petroleum Hydrogeology of the Great Hungarian Plain, Eastern Pannonian Basin, Hungary. PhD értekezés, University of Alberta, Edmonton, Canada, p. 312.

Anderson, E. M. (1951). The Dynamics of Faulting and Dyke Formation with Applications to Britain. Edinburgh, Oliver and Boyd.

Babadagli, T. (2001). Fractal Analysis of 2-D Fracture Networks of Geothermal Reservoirs in South-western Turkey. J. of Volcanology and Geothermal Res., vol. 112/1-4, p. 83-103.

Bada, G., Ruszkiczay Rüdiger, Zs., Windhoffer, G. (2007). Neotektonika szerepe a Magyar Középhegység fiatal morfostrukturális fejlődésében. Project Report. OTKA.

Bahorich, M., Farmer, S. (1995). 3-D seismic discontinuity for faults and stratigraphic features: The coherency cube: The Leading Edge, Vol. 24.10.

Barton, N. (1973). Review of a new shear strength criterion for rock joints: Engineering Geol., v. 7 , p. 287-332.

Barton, C. C. (1995). Fractal analysis of scaling and spatial clustering of fractures. In: Barton, C. C., La Pointe, P. R. (eds.): Fractals in the Earth Sciences. Plenum Press, New York, p. 168.

Barton, C. C., Larsen, E. (1985). Fractal geometry of two-dimensional fracture networks at Yucca Mountain, Southwestern Nevada. In: Stephanson, O. (ed.): Proc. Int. Symp. on Fundamentals of Rock Joints, p. 77-84.

Barton, C. C., La Pointe, P. R., Malinverno, A. (1991). Fractals and their use in Earth sciences. Short course manual. Geol Soc Am ann meeting, San Diego, CA.

Bear, J. (1972). Dynamics of fluids in porous media, Elsevier, New York, p.764.

Beardsmore, G. R., Cull, J. P. (2001). Crustal heat flow: a guide to measurement and modelling. Cambridge, Cambridge University Press, p. 324.

Benedek, K., Bőthi, Z., Mező, Gy., Molnár, P. (2009). Compartmented flow at the Bátaapáti site in Hungary. Hydrogeology Journal, 17, p. 1219-1232. 
Bloomfield, J. (1996). Characterization of hydrogeologically significant fracture distributions int the Chalk: an example from the Upper Chalk of southern England. J. of Hydrology, 184, p. 355-379.

Bredehoeft, J. D., Papadopulos, I. S. (1965). Rates of vertical groundwater movement estimated from the Earth's thermal profile: Water Resources Research, v. 1, p. 325-328.

Brigaud, F., Chapman, D. S., Le Douaran, S. (1990). Estimating thermal conductivity in sedimentary basins using lithologic data and geophysical well logs. AAPG Bulletin, 74(9), p. 1459-1477.

Bürgmann, R., Pollard, D. D., Martel, S. J. (1994). Slip distributions on faults: effects of stress gradients, inelastic deformation, heterogeneous host-rock stiffness and fault interaction. J. Struct. Geol. 16, p. 1675-1690.

Cacas, M. C., Ledoux, E., de Marsily, G., Tillie, B. (1990). Modeling fracture flow with a stochastic discrete fracture network: calibration and validation. 1: The flow model. Water Resources Research, 26, p. 479-489.

Caine, J. S., Evans, J. P., Forster, C. B. (1996). Fault zone architecture and permeability structure, Geology, v. 24, p. 1025-1028.

Carlson, W. D., Rowe, T., Ketcham, R. A., Colbert, M. W. (2003). Geological applications of high-resolution X-ray computed tomography in petrology, meteoritics and paleontology. In: Mees, F., Swennen, R., van Geet, M., Jacobs, P. (eds) Applications of X-ray computed tomography in geosciences. 215, p. 7-22.

Carrera, J., Heredia, J., Vomvoris, S., Hufschmied, P. (1990). Modeling of flow on a small fractured monzonitic gneiss block. Pp. 115-167 in Hydrogeology of Low Permeability Environments, International Association of Hydrogeologists, Hydrogeology: Selected Papers, vol. 2, S. P. Neuman and I. Neretnieks, eds. Hannover: Heise.

Cartwright, J. A., Trudgill, B., and Mansfield, C. S. (1995). Fault growth by segment linkage: An explanation for scatter in maximum displacement and trace length data from the Canyonlands grabens of SE Utah: J. Struct. Geol., v. 17, p. 1319-1326.

Cermak, V., Bodri, L., Rybach L., Buntebarth, G. (1990). Relationship between seismic velocity and heat production: comparison of two sets of data and test of validity. Earth and Planetary Science Letters, 99, p. 48-57. 
Chaplow, R. (1996). The geology and hydrogeology of Sellafield: An overview, Quarterly J. Engineering Geology, 29, p. 1-12.

Chapman, D. S., Keho, T., Bauer, M., Picard, M. D. (1984). Heat flow in the Uinta basin determined from bottom hole temperature (BHT) data. Geophysics, v. 49, p. 453-466.

Chiang, W-H., Kinzelbach, W. (1999). Processing Modflow: A simulation system for modelling groundwater flow and pollution, v5.0, User's manual, kézirat.

Cladouhos T. T., Marrett, R. (1996). Are Fault Growth and Linkage Models Consistent with Power-Law Distribution of Fault Length? J. Struct. Geol., 17, p. 863-873.

Clark, R. M., Cox, S. J. D. (1996). A modern regression approach to determining fault displacement length scaling relationship: J. Struct. Geol., v. 18, p. 147-152.

Clark, S. P. Jr. (1966). Thermal conductivity, in Handbook of physical constants, edited by S. P. Clark Jr., p. 459-482, Geol Soc of America, Memoir 97, New York.

Clauser, C., Huenges, E. (1995). Thermal conductivity of rocks and minerals. Rock Physics and phase relations, A handbook of physical constants. AGU reference shelf 3, p. 105-126.

Committee on Fracture Characterization and Fluid Flow (1996). Rock Fractures and Fluid Flow: Contemporary Understanding and Applications, Washington D.C., National Academy Press, p. 551 .

Cowie, P. A., Scholz, C. (1992). Displacement-Length scaling relationship for faults. Data synthesis and discussions: J. Struct. Geol., v. 14, p. 1149-1156.

Császár, G. (szerk.) (1997). Magyarország litosztratigráfiai alapegységei. MÁFI - Magyar Rétegtani Bizottság, Budapest.

Davatzes, N.C., Hickman, S. (2005). Comparison of acoustic and electrical image logs from the Coso geothermal field, CA. Proceedings, Thirtieth Workshop on Geothermal Reservoir Engineering, Stanford University, January 31- February 2, 2005. SGP-TR-176, p. 1-11.

Dershowitz, W. S. (1984). Rock joint systems, Ph.D. thesis, Massachusetts Institute of Technology, Cambridge.

Dershowitz, W. S., Lee, J., Geier, J., La Pointe, P. R. (1998). FracMan: Interactive Discrete Fracture Data Analysis, Geometric Modelling, and Exploration Simulation. p. 154. 
Dezayes, C., Valley, B., Maqua, E., Sysen, G., Genter, A. (2005). Natural fracture system of the Soultz granite based on UBI data in the GPK3 and GPK4 wells, Proceedings, EHDRA Scientific Meeting. Soultz-sous-Forêts, France.

Diersch, H.-J. (2002). FEFLOW finite-element subsurface flow and transport simulation system. User's Manual/Reference Manual/White Papers, Release 5.0.

Dövényi, P., Horváth, F., Liebe, P., Gálfi, J., Erki, I. (1983). Geothermal conditions of Hungary. Geophys. Transact., 29, p. 3-114.

Dövényi, P., Homola, V., Horváth, F., Kohl, T., Rybach, L. (2005). European HDR/EGS resources: Future potential development in Hungary. Final Report, GEOWATT AG (May 26, 2005), p. 1-41.

Ehlen, J. (1993). Variations in fractal dimension for joint patterns in granitic rocks. Geol Soc Am Abstr Progr 25:A33.

Ehlen, J. (1999). Fracture characteristics in weathered granite. Geomorphology 31, p. 29-45.

Ehlen, J. (2000). Fractal analysis of joint patterns in granite. Int J Rock Mech Min Sci 37, p. $909-922$.

Engelder, T., Leftwich, J. T. (1997). A pore-pressure limit in overpressured south Texas oil and gas fields. Seals, traps and the petroleum system: AAPG Memoir 67. R. C. Surdam. Tulsa, OK, AAPG, p. 255-267.

Evans, J. P., Forster, C. B., Goddard, J. V. (1997). Permeability for fault related rocks and implication for hydraulic structure of fault zones. Journal of Structural Geology, 19, p. 1393-1404.

Fisher, R. A. (1953). Dispersion on a sphere. Proceedings of the Royal Society of London, Series A, 217, p. 295-305.

Fodor, L. I. (2010). Mezozoos-kainozoos feszültségmezők és törésrendszerek a Pannon-medence ÉNy-i részén - módszertan és szerkezeti elemzés. Akadémiai doktori értekezés, Budapest, p. 128.

Freeze, R. A., Cherry, J. A. (1979). Groundwater. Prentice-Hall, Inc. Englewood Cliffs, NJ. p. 604.

Fülöp, J. (1994). Magyarország geológiája. Paleozoikum 2. Budapest, Akadémia Kiadó, p. 447.

Geiger, J., Hunyadfalvi, Z., Bogner, P. (2008). Analysis of small-scale heterogeneity in clastic rocks by using computerized X-ray tomography (CT). Engineering Geology. vol. 103. 3-4. p. 112-118. 
Gordon, D. S., Flemings, P. B. (1998). Generation of overpressure and compaction-driven fluid flow in a Plio-Pleistocene grwoth-faulted basin, Eugene Island 330, offshore Louisiana. Basin Research, 10, p. 177-196.

Haas, J., Budai, T., Csontos, L., Fodor, L., Konrád, Gy. (2010). Magyarország pre-kainozoos földtani térképe, 1 : 500 000. Földtani Intézet kiadványa, Budapest.

Hedin, A. (2008). Semi-analytic stereological analysis of waste package/fracture intersections in a granitic rock nuclear waste repository. Mathematical Geosciences; 40, p. 619-637.

Horváth, E. (1993). Towards a mechanical model for the formation of the Pannonian basin. Tectonophysics, 226, p. 333-357.

Hounsfield, G. N. (1972). A method of and apparatus for examinations of a body by radiation such as X- or gamma- radiation, British Patent No. 1,283,915, London.

Hubbert, M. K. (1940). The theory of ground-water motion. Journal of Geology, v. 48, p. 785-944.

Huitt, J. L. (1955). Fluid Flow in Simulated Fractures, Amer. Inst. Chem. Eng. Journal, vol. 2, p. $259-264$.

Jamison, W. R. (1997). Quantitative evaluation of fractures on Monkshood anticline, a detachment fold in the foothills of western Canada: Am. Assoc. Petroleum Geologists Bull., v. 81, p. 1110-1132.

Jing, L., Stepahnsson, O. (1995). Mechanics of rock joints: experimental aspects. In: Mechanics of Geomaterial interfaces (eds. Selvadurai \& Boulon), Elsevier, Amsterdam, p. 317-342.

Johnston, J. D., McCaffrey, K. J.W. (1996). Fractal geometries of vein systems and the variation of scaling relationships with mechanism: J. Struct. Geol., v. 18, p. 349-358.

Kaszai, B. (2003). A Mórágyi gránit repedezettsége az erdősmecskei bánya területén. (Brittle deformation of Mórágy granite around Erdősmecske, Hungary). MSc thesis, University of Szeged, Dept. Mineralogy, Geochemistry and Petrology, p. 52.

Klötzli, U. S., Buda, G., Skiöld, T. (2004). Zircon typology, geochronology and whole rock Sr-Nd isotope systematics of the Mecsek Mountain granitoidsin the Tisia Terrane (Hungary). Mineralogy and Petrology, 81(1-2), p. 113-134.

Kohl, T., Baujard, C., Zimmermann, G. (2007). Modelling geothermal reservoirs - an overview. ENhanced Geothermal Innovative Network for Europe Mid-term Conference, Potsdam. 
Kovács B. (2004). Hidrodinamikai és transzportmodellezés Processing MODFLOW környezetben I., Miskolci Egyetem - Szegedi Tudományegyetem - Gámageo, p. 160.

Lelkesné Felvári, Gy. (2007). A metamorf fejlődéstörténet egyes eseményeinek elkülönítése és jellemzése geokronológiai módszerek segítségével magyarországi polimetamorf kőzetekben. Project Report, OTKA.

Lespinasse, M. (2000). Quantification of fluid flow: hydro-mechanical behaviour of different natural rough fractures. Journal of Geochemical Exploration (69-70), p. 483-486.

Lomize, G. M. (1951). Filtratsiya v Treshchinovatykh Porodakh. (Flow in fractured rocks), Gosenergoizdat, Moscow, p. 127.

Long, J. C. S., Remer, J. S., Wilson, C. R., Witherspoon, P. A. (1982). Porous media equivalents for networks of discontinuous fractures. Water Resources Research, 18(3), p. 645-658.

Lorberer, Á., Tóth, Gy., Takács, E., Fodor, B., Rezessy G., Szanyi, J., Davideszné Dömötör, K., Nagy, A., Szita, K., Szőcs, M., Dövényi, P., Szafián, P., Hajdú, Gy., Csarankó, F. (2004). A geotermális energiahasznosítás fejlesztési koncepciója 2010-ig. Összefoglaló jelentés, kézirat, Vízgazdálkodási Tudományos Kutató Rt., Budapest, 43.

M. Tóth, T. (2008). Repedezett, metamorf fluidumtárolók az alföld aljzatában. MTA doktori értekezés, Szeged, p. 399.

M. Tóth, T. (2010). Determination of geometric parameters of fracture networks using 1D data. Journal of Structural Geology, 32, p. 878-885.

M. Tóth, T., Schubert, F., Zachar, J. (2000). Neogene exhumation of the Variscan Szeghalom dome, Pannonian Basin, E. Hungary. J. Geol. 35/3-4, p. 265-284.

M. Tóth, T., Szücs, É., Schubert, F., Hollós, Cs. (2004). Conceptual fracture network model of the crystalline basement of the Szeghalom Dome (Pannonian Basin, SE Hungary). Acta Geol. Hung. 47(1), p. 19-34.

M. Tóth, T., Zachar, J. (2006). Petrology and deformation history of the metamorphic basement in the Mezősas-Furta crystalline high (SE Hungary). Acta Geol. Hung., 49/2, p. 165-188.

M. Tóth, T., Vass, I., Schubert, F. (2006). Repedéshálózat szimuláció és paleofluidum rekonstrukció szerepe kommunikáló törésrendszerek vizsgálatában. In: Török Ákos, Vásárhelyi Balázs (ed.) Mérnökgeológia-Kőzetmechanika 2006. Budapest, Hungary, Mủegyetemi Kiadó, p. 163-184. 
M. Tóth, T., Vass, I., Szanyi, J., Kovács, B. (2007). Water and heat flow through uplifted metamorphic highs in the basement of the Pannonian Basin. In: Groundwater and Ecosystems. Lisbon, Portugal, 17-21/Sep/2007, p. 503-512.

M. Tóth, T., Redlerné Tátrai, M., Kummer, I., (2008). A Szeghalom környéki metamorf aljzat kiemelkedés szerkezetfejlődése és felépítése kőzettani és szeizmikus adatok alapján. Magyar Geofizika, 49/4, p. 143-151.

M. Tóth, T., Vass, I. (2011). Relationship between the geometric parameters of rock fractures, the size of percolation clusters and REV. J. Mathematical Geosciences, 43, p. 75-97.

Mádl-Szőnyi, J., Tóth, J. (2009). A hydrogeological type section for the Duna-Tisza Interfluve. Hydrogeology Journal Vol. 17. No. 4. p. 961-980.

Mádlné Szőnyi, J., Tóth, J., Simon, Sz., Pogácsás, Gy. (2005). Felszíni és felszínalatti vizek kapcsolatának eredménye a Duna-Tisza közi Kelemen-szék és Kolon-tó esetében. Általános Földtani Szemle, 30, pp. 93-110.

Mandelbrot, B. B. (1983). The Fractal Geometry of Nature. Freeman, New York, pp. 468.

Mandelbrot, B. B. (1985). Self-affine fractals and fractal dimension. Physica Scripta 32, p. $257-260$.

Maros, Gy., Koroknai, B., Palotás, K., Fodor, L., Dudko, A., Forián-Szabó, M., Zilahi-Sebess, L., Bán-György, E. (2003). Tectonic analysis and structural evolution of the north-eastern Mórágy Block. Annual Report of the Geological Institute of Hungary, p. 371-386.

Massonnat, G., Viszkok, J., Vrignon, M. (2002). Hierarchical organization of flow network in fractured carbonate reservoirs: identification and characterization of key parameters. Proceedings SPE annual technical conference and exhibition 2002, p. 1381-1398.

McCain, W. D. (1990). The Properties of Petroleum Fluids, 2nd Edition. Pennwell Publishing, p. 548.

Mees, F., Swennen, R., Van Geet, M., Jacobs, P. (2003). Applications of X-ray computed tomography in the geosciences. Geological Society, London, Special publications, 215, p. 1-6.

Min, K. B., Jing, L., Stephansson, O. (2004). Determining the equivalent permeability tensor for fractured rock masses using a stochastic REV approach: Method and application to the field data from Sellafield, UK. Hydrogeology Journal; 12(5), p. 497-510. 
Morrow, C. A., Lockner, D. A. (1994). Permeability differences between surface-derived and deep drillhole core samples. Geophysical Research Letters, V. 21(19), p. 2151-2154.

Morrow, C., Lockner, D., Hickman, S. (1994). Effects of lithology and depth on the permeability of core samples from the Kola and KTB drill holes. Journal of Geophysical Research, V. 99(B4), p. 7263-7274.

Muffler, P., Cataldi, R. (1978). Methods for regional assessment of geothermal resources, Geothermics, 7, p. 53-89.

Nelson, R. A. (2001). Geologic Analysis of Naturally Fractured Reservoirs (2nd Edition). Gulf Professional Publishing, Elsevier, p. 332.

Oda, M. (1985). Permeability Tensor for Discontinuous Rock Masses, Geotechnique Vol. 35, p. 483.

Olson, J. E. (1993). Joint pattern development: Effects of subcritical crack growth and mechanical crack interaction: J. Geophys. Rese., v. 98(B7), p. 12, 251-212, 265.

Oppermann, R. H. J. (2012). High-resolution fracture recognition from seismic data - applying oil and gas technology to mining. Deep Mining 2012, Australian Centre for Geomechanics, Perth, p. 247-256.

Osborne, M. J., Swarbrick, R. E. (1997). Mechanisms for generating overpressure in sedimentary basins; a reevaluation: American Association of Petroleum Geologists Bulletin, v. 81, p. 1023-1041.

Özkaya, S. I. (2003). Fracture length estimation from borehole image logs. Mathematical Geology, 35(6), p. 737-753.

Patton, F. D. (1966). Multiple modes of shear failure in rock. Proc. 1st. Congr., Int. Soc. Rock Mech. (1), p. 509-513.

Peacock, D. C. P. (1991). Displacements and segment linkage in strike slip fault zones: J. Struct. Geol., v. 13, p. 1025-1035.

Pepper, R., Bejarano, G. (2005). Advances in seismic fault interpretation automation. Search and Discovery Article, \#40169, p. 1-16.

Pethő, S., Vass, I. (2011). Deep-geothermal plays in Hungary, Heat resource estimation and ranking. Internal exploration report, CEGE Zrt., Budapest.

Pollack, H. N., Hurter, S. J., Johnson, J. R. (1993). Heat flow from the Earth's interior: analysis of the global data set. Rev. Geophys. 31, p. 267-280. 
Prensky, S. E. (1999). Advances in borehole imaging technology and applications. In: Lovell, M. A., Williamson, G and Harvey, P. K. (eds.). Borehole Imaging: Applications and Case Histories. Geological Society Special Publication No. 159, p. 1-43.

Pruess, K. (1991). TOUGH2 - A General-Purpose Numerical Simulator for Multiphase Fluid and Heat Flow. LBNL-29400, UC-251, Earth Sciences Division, Lawrence Berkeley National Laboratory, Berkeley, CA.

Pruess, K., Narasimhan, T. N. (1988). Numerical modeling of multiphase and nonisothermal flows in fractured media. In proceedings of the symposium conference on fluid flow in fractured rocks, Georgia State University, May 15-18.

Ranalli, G., Gale, A. D. (1976). "Lectures on the Rheology of the Earth, Part I: Basic Concepts," Carleton University, Department of Geology, Geological Paper 76-1, Ottawa, Canada, p. 157.

Riley, M. S. (2004). An algorithm for generating rock fracture patterns: Mathematical analysis. Mathematical Geology, 36(6), p. 683-702.

Rouai, M. (2006). Application of fractal geometry to 2D fracture networks in the middle Atlas aquifer (Marocco). Poster presented at the 9th AGILE Conference on Geographic Information Science, Visegrád, Hungary, 2006.

Roxar (2005). FracPerm Reference Manual.

Roy, R. F., Beck, A. E., Touloukian, Y. S. (1981). Thermophysical properties of rocks, in Touloukian, Y. W., Judd, W. R., Ho, C. Y. eds., Physical properties of rocks and minerals, New York, McGraw-Hill, p. 409-502.

Royden, L. H., (1988). Late Cenozoic tectonics of the Pannonian basin system. In: Royden, L. H., Horváth, E. (szerk.), The Pannonian Basin. Ass. Amer. Petr. Geol. Mem., 45, p. 27-48.

Scholz, C. H., Cowie, P. A. (1990). Determination of total strain from faulting using slip measurements. Nature, 346, p. 837-839.

Schubert, F., Diamond, L. W., M. Tóth, T. (2007). Fluid inclusion evidence of petroleum migration through a buried metamorphic dome in the Pannonian Basin, Hungary. Chemical Geology, 244/3-4, p. 357-381.

Segall, S. W., Pollard, D. D. (1983). Joint formation in granitic rocks of the Sierra Nevada. Geological Society of America Bulletin, 94, p. 563-575. 
Simon, Sz., Mádlné Szőnyi, J., Müller, I., Zsemle, F. (2009). Geophysical and chemical identification of near-surface saline water, Lake Kelemenszék Area. Central European Geology, 51(3): 219-230.

Singhal, B. B. S., Gupta, R. P. (1999). Applied hydrogeology of fractured rocks. Springer, p. 408.

Snow, D. T. (1965). A parallel plate model of fractured permeable media. Ph.D. thesis, University of California, Berkeley, p. 331.

Somerton, W. H. (1992). Thermal properties and temperature-related behavior of rock/fluid systems, W.H. Somerton Elsevier, Amsterdam; New York, p. 257.

Stearns, D.W., Friedman, M. (1972). "Reservoirs in Fractured Rock", American Association of Petroleum Geology, Memoir 16, pp. 82-100.

Stüwe, K. (2007). Geodynamics of the lithosphere: an introduction (2nd edition). Springer, p. 493.

Snow, D. T. (1965). A Parallel Plate Model of Fractured Permeable Media, Ph.D. Dissertation, University of California.

Szalay, Á. (1982). A túlnyomás okai és a paleopórusnyomás becslése, Kőolaj és Földgáz, v. 115, p. 41-46.

Szanyi, J., Kovács, B. (2010). Utilization of geothermal systems in South-East Hungary. Geothermics 39, p. 357-364.

Tari, G. (1994). Alpine tectonics of the Pannonian basin. PhD thesis, Rice University, Houston, Texas, p. 501.

Terzaghi, R. (1965). Sources of error in joint surveys. Geotechnique; 15, p. 287-304.

Tester, J. W., Anderson, B. J., Batchelor, A. S., Blackwell, D. D., DiPippo, R., Drake, E. M., Garnish, J., Livesay, B., Moore, M. C., Nichols, K., Petty, S., Toksöz, M. N., Veatch, R. W. Jr. (2006). The Future of Geothermal Energy: Impact of Enhanced Geothermal Systems (EGS) on the United States in the 21st Century, Massachusetts Institute of Technology, Cambridge, MA: http://geothermal.inel.gov.

Tóth, J., Almási, I. (2001). Interpretation of observed fluid potential patterns in a deep sedimentatry basin under tectonic compression: Hungarian Great Plain, Pannonian Basin; Geofluids, 1(1), p. 11-36.

Twiss R. J. \& Moores, E. M. (1992). Structural Geology, New York: W. H. Freeman and Company. 532 p. 
Tsuchiya, N., Nakatsuka, K. (1995). Fractal analysis and modeling of a two-dimensional fracture network in a geothermal reservoir. Geotherm. Res. Coun. Trans. 19, p. 547-552.

Tsuchiya, N., Nakatsuka, K. (1999). A two-dimensional monofractal approach to natural fracture networks in rock. Geotherm. Sci. Tech. 6, p. 63-82.

Van Balen, R., Cloetingh, S. (1994). Tectonic control of the sedimentary record and stress-induced fluid flow. In: Geofluids: origin, migration, and evolution of fluids in sedimentary basins, J. Parnell (ed.), Geological Society of London, Spec. Pub. 78, p. 9-26.

Van Ruth, P., Hillis, R., Swarbrick, R., Tingate, P., Midren, S. (2003). The Origin of Overpressure in the Cooper Basin, Australia. ASEG Extended Abstracts 2003, p. 1-5.

Varsányi, I., Mátray, J.-M., Ó. Kovács, L. (1999). Hydrogeochemistry in two adjacent areas in the Pannonian Basin (Southeast-Hungary) - Chemical Geology, v. 156, p. 25-39.

Varsányi, I., Ó. Kovács, L. (2009). Origin, chemical and isotopic evolution of formation water in geopressured zones in the Pannonian Basin, Hungary. Chemical Geology, 264, p. 187-196.

Vass, I., M. Tóth, T. (2007). A Reprezentatív Elemi Térfogat (REV) meghatározása sztochasztikusan generált repedéshálózatok vizsgálatával. In: Török Á, Vásárhelyi B (ed.) Mérnökgeológia-Közetmechanika 2007. Budapest: Müegyetemi Kiadó, p. 53-62.

Vass, I., M. Tóth, T., Szanyi, J., Kovács, B. (2009). Az aljzati kristályos hátak szerepe az Alföld fluidum áramlási és hőtranszport folyamataiban. In: M. Tóth Tivadar (ed.) Magmás és metamorf képződmények a Tiszai Egységben. Szeged, Geolitera SZTE Földrajzi és Földtani Tanszékcsoport, p. 325-339.

Velde, B., Dubois, J., Moore, D., Touchard, J. (1991). Fractal patterns of fractures in granites. Earth Planet Sci Lett 104, p. 25-35.

Vermilye, J. M., Scholz, C. H. (1995). Relation between vein length and aperture. J. Struct. Geology., v. 17, p. 423-434.

Voss, C. I., Provost, A. M. (2010). SUTRA - A model for saturated-unsaturated, variable-density ground-water flow with solute or energy transport. USGS Water-Resources Investigations Report 02-4231, Reston, Virginia.

Walsh, J. J., Watterson, J. (1988). Analysis of the relationship between displacement and dimensions of faults: J. Struct. Geol., v. 10, p. 239-247. 
Waterloo Hydrogeologic Inc. (2006). Visual MODFLOW User's Manual for professional applications in three-dimensional groundwater flow and contaminant transport modeling. p. 632.

Williams, C. (2007). Updated Methods for Estimating Recovery Factors for Geothermal Resources. Thirty second Workshop on Geothermal Reservoir Engineering, Stanford University.

Witherspoon, P. A., Wang J. S. Y., Iwai, K. (1980). Validity of cubic law for fluid flow in deformable rock fracture. Water Resources Res. 16(6), p. 1016-1024.

Yielding, G., Walsh, J. J., Watterson, J. (1992). The prediction of small-scale faulting in reservoirs. First Break; 10, p. 449-460.

Zilahi-Sebess, L., Gyuricza, Gy. (2012a). Gádoros geotermikus koncessziós terület komplex érzékenységi és terhelhetőségi vizsgálati jelentés. MBFH, Budapest, p. 208.

Zilahi-Sebess, L., Gyuricza, Gy. (2012b). Kecskemét geotermikus koncessziós terület komplex érzékenységi és terhelhetőségi vizsgálati jelentés. MBFH, Budapest, p. 176. 
A. melléklet: a legnagyobb törésklaszter relatív méretének változása az $E, D$ és $\alpha$ paraméterek függvényében
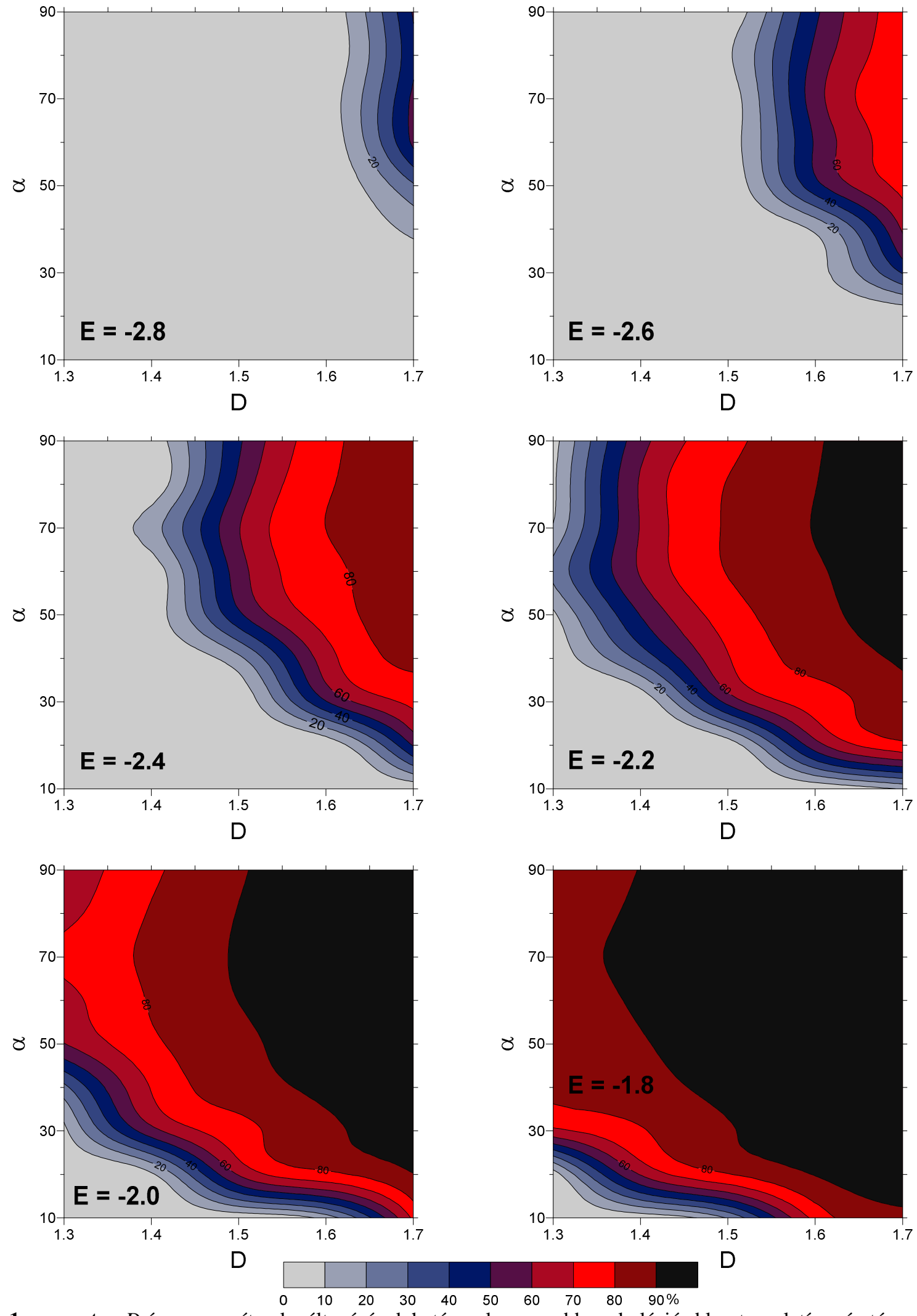

1. sorozat: a $D$ és $\alpha$ paraméterek változásának hatása a legnagyobb perkolációs klaszter relatív méretére 

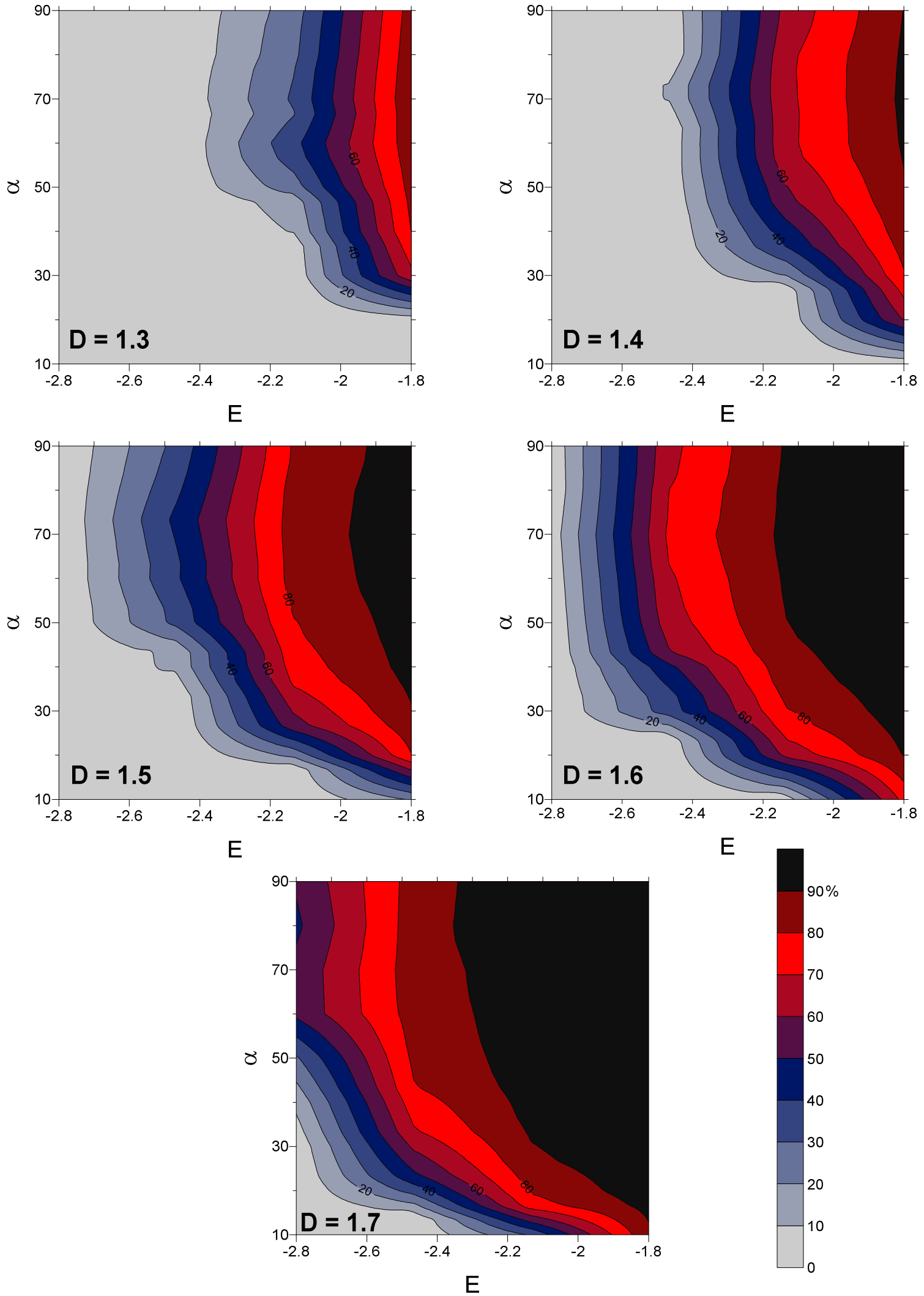

2. sorozat: az $E$ és $\alpha$ paraméterek változásának hatása a legnagyobb perkolációs klaszter relatív méretére 

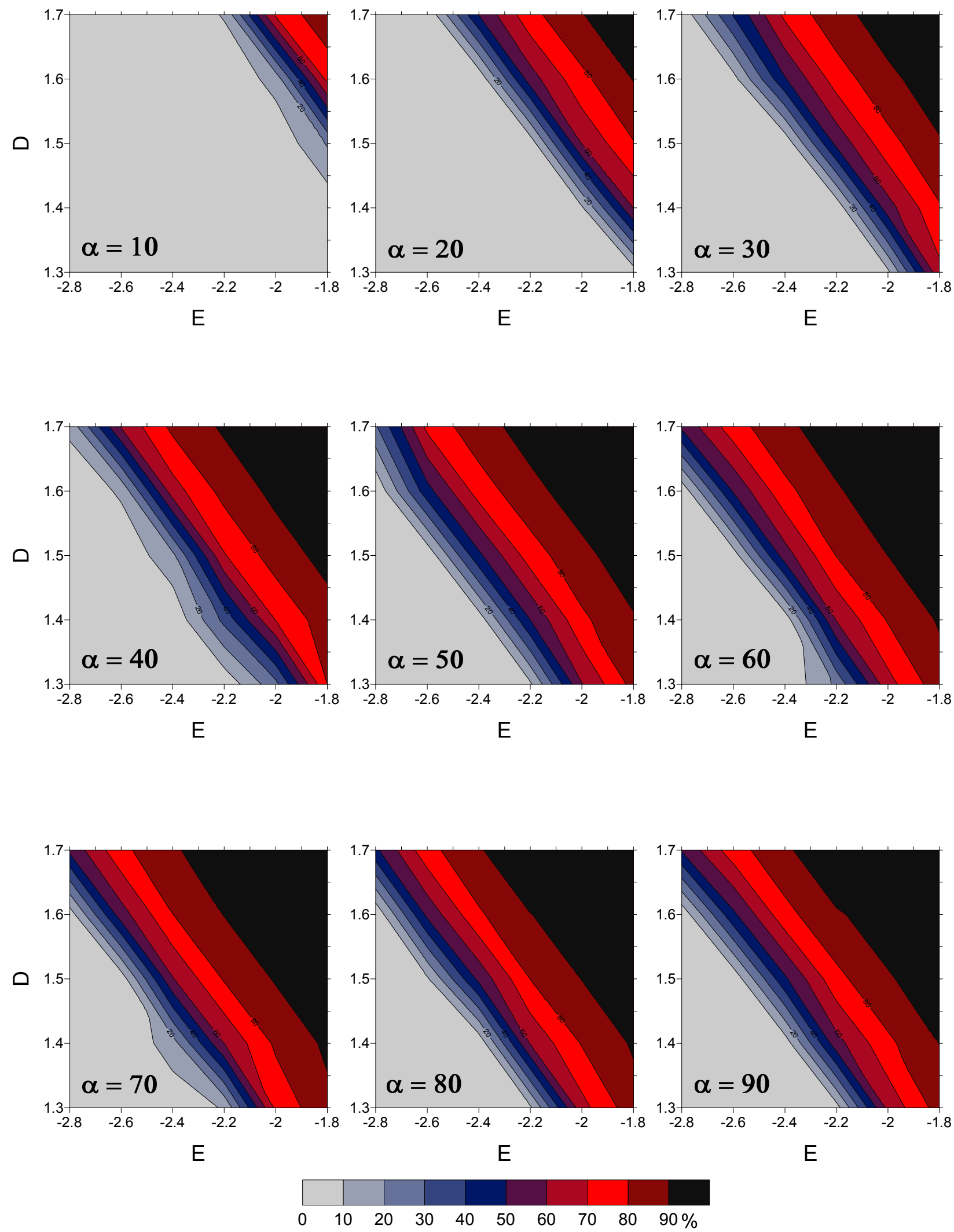

3. sorozat: az $E$ és $D$ paraméterek változásának hatása a legnagyobb perkolációs klaszter relatív méretére 
B. melléklet: a legnagyobb törésklaszter relatív mérete szórásának változása az $E, D$ és $\alpha$ paraméterek függvényében
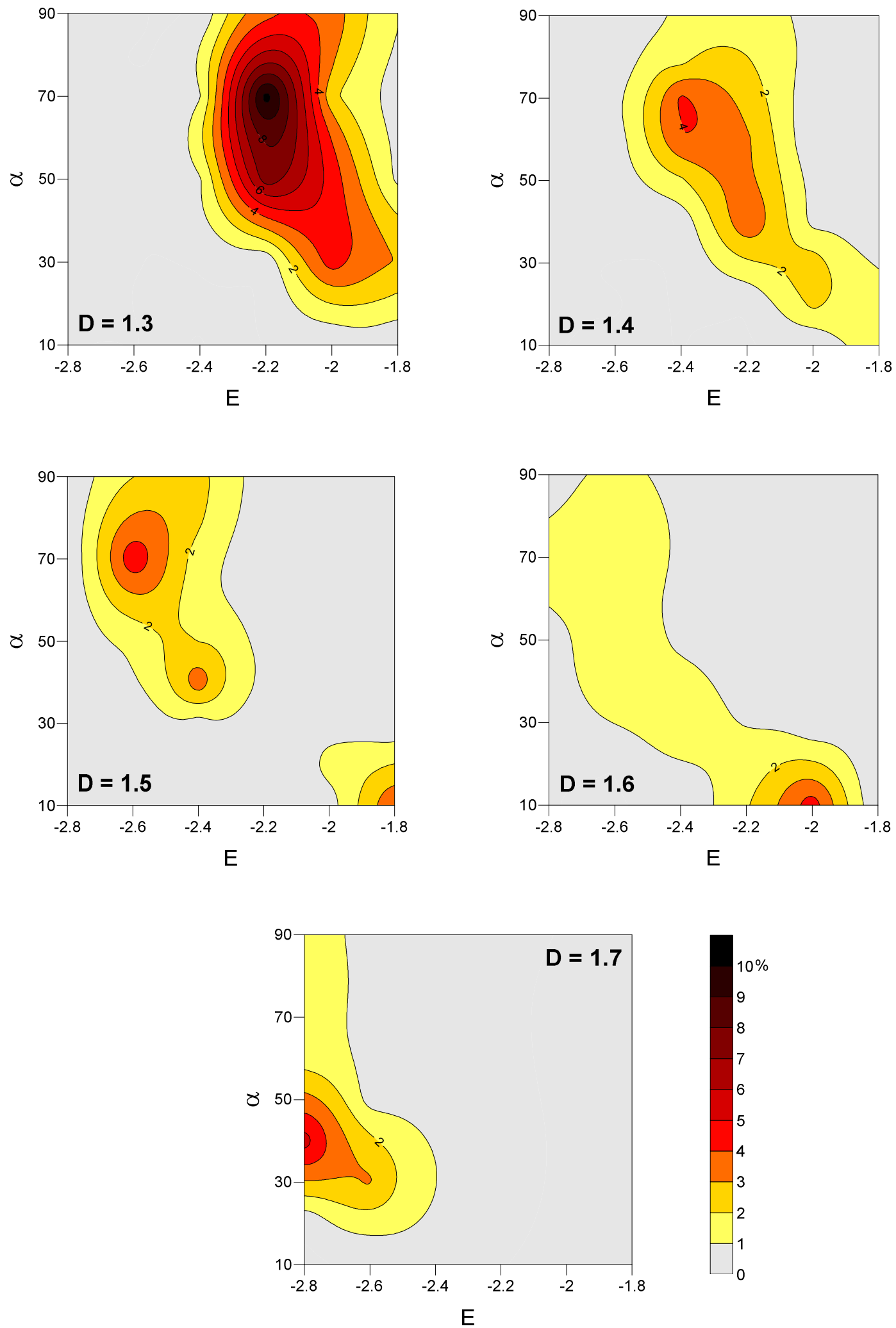

$\mathrm{E}$

4. sorozat: az $E$ és $\alpha$ paraméterek változásának hatása a legnagyobb perkolációs klaszter relatív méretének szórására 

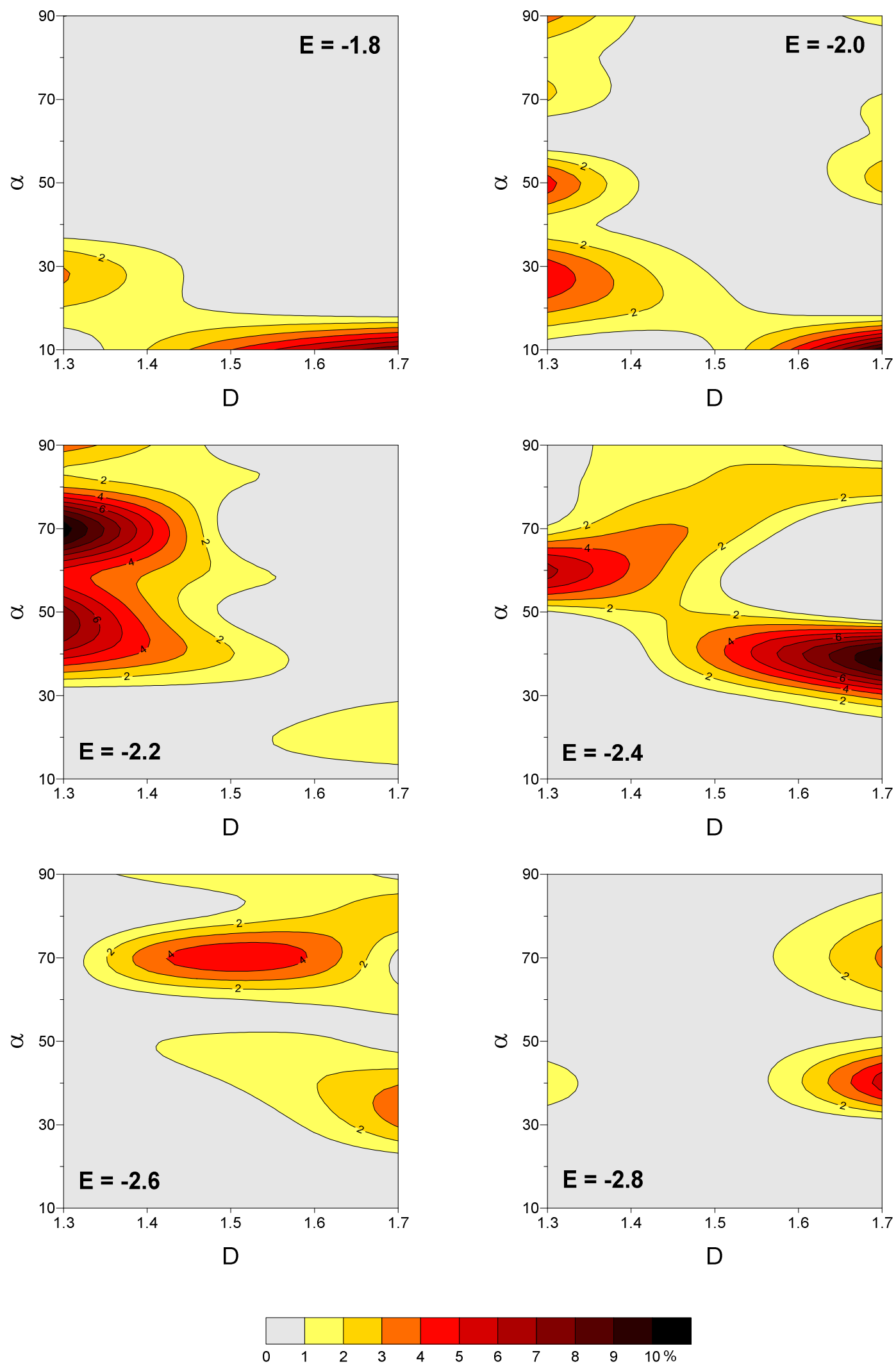

5. sorozat: a $D$ és $\alpha$ paraméterek változásának hatása a legnagyobb perkolációs klaszter relatív méretének szórására 

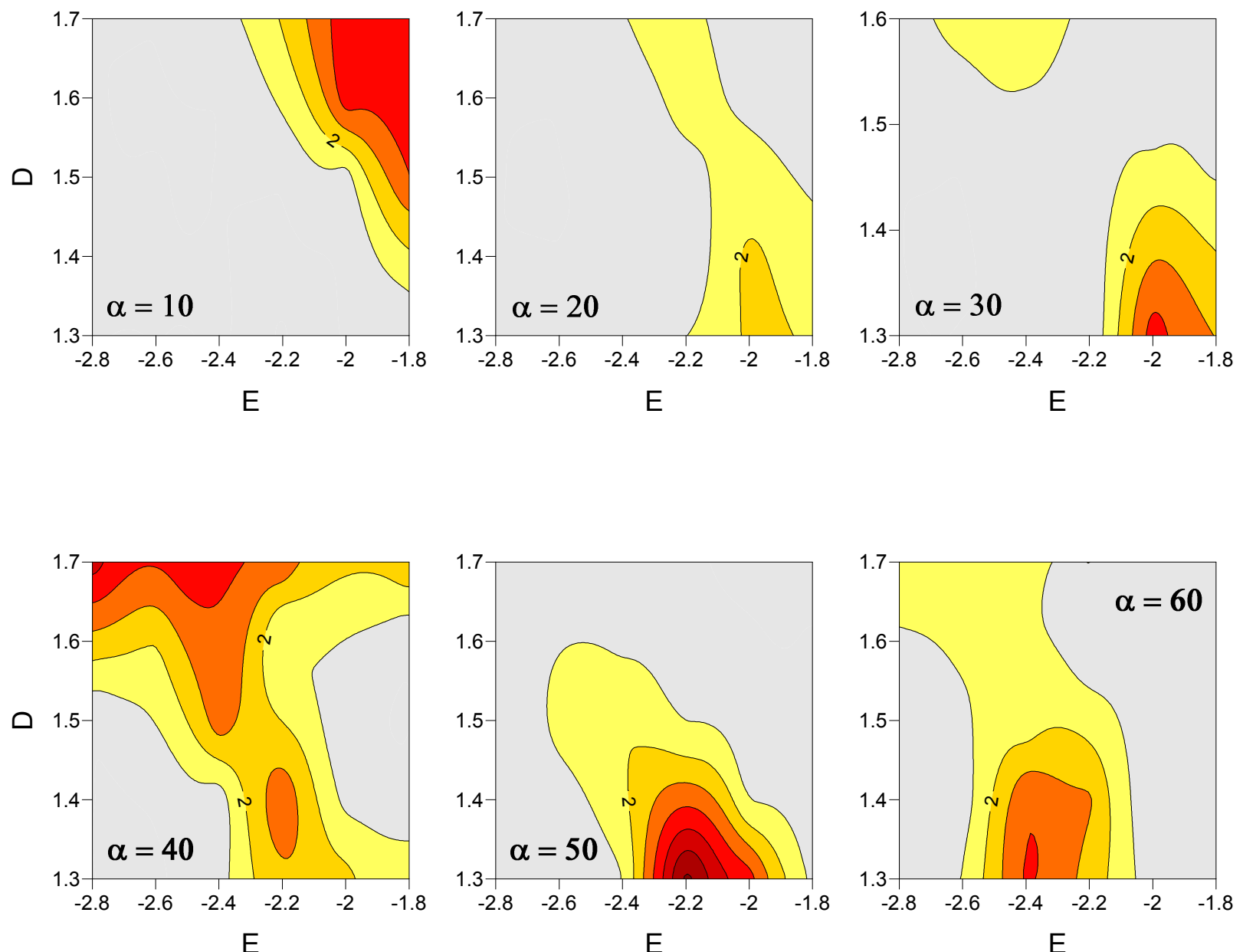

$\mathrm{E}$

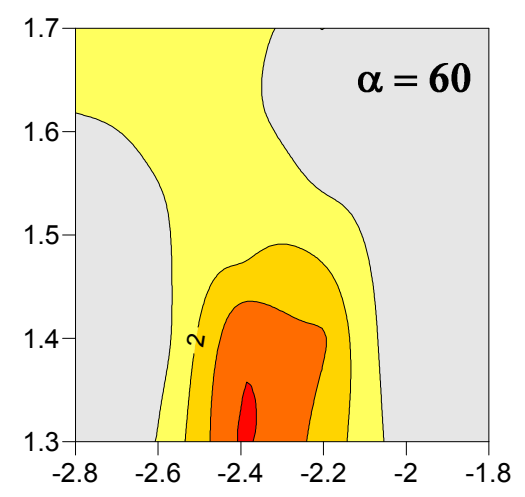

$\mathrm{E}$
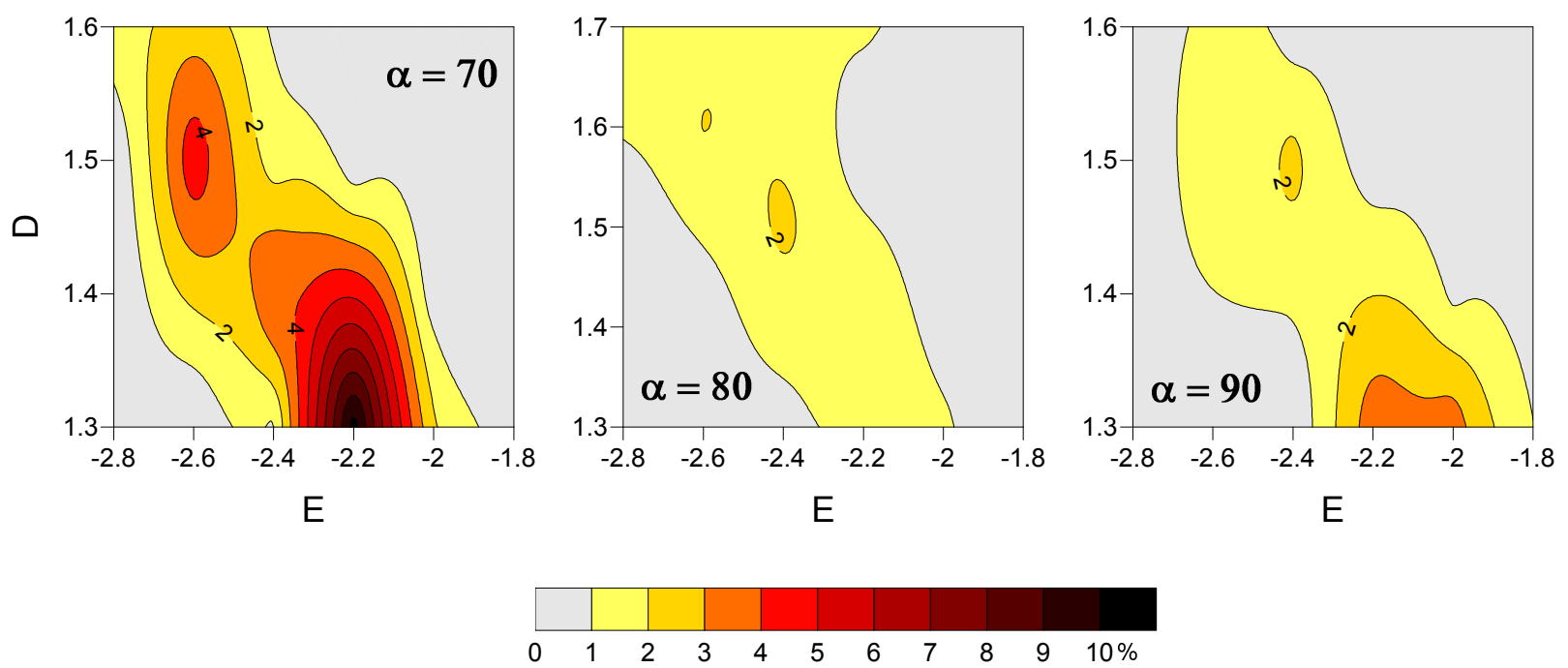

6. sorozat: az $E$ és $D$ paraméterek változásának hatása a legnagyobb perkolációs klaszter relatív méretének szórására 
C. melléklet: a második legnagyobb törésklaszter relatív méretének változása az $E, D$ és $\alpha$ paraméterek függvényében
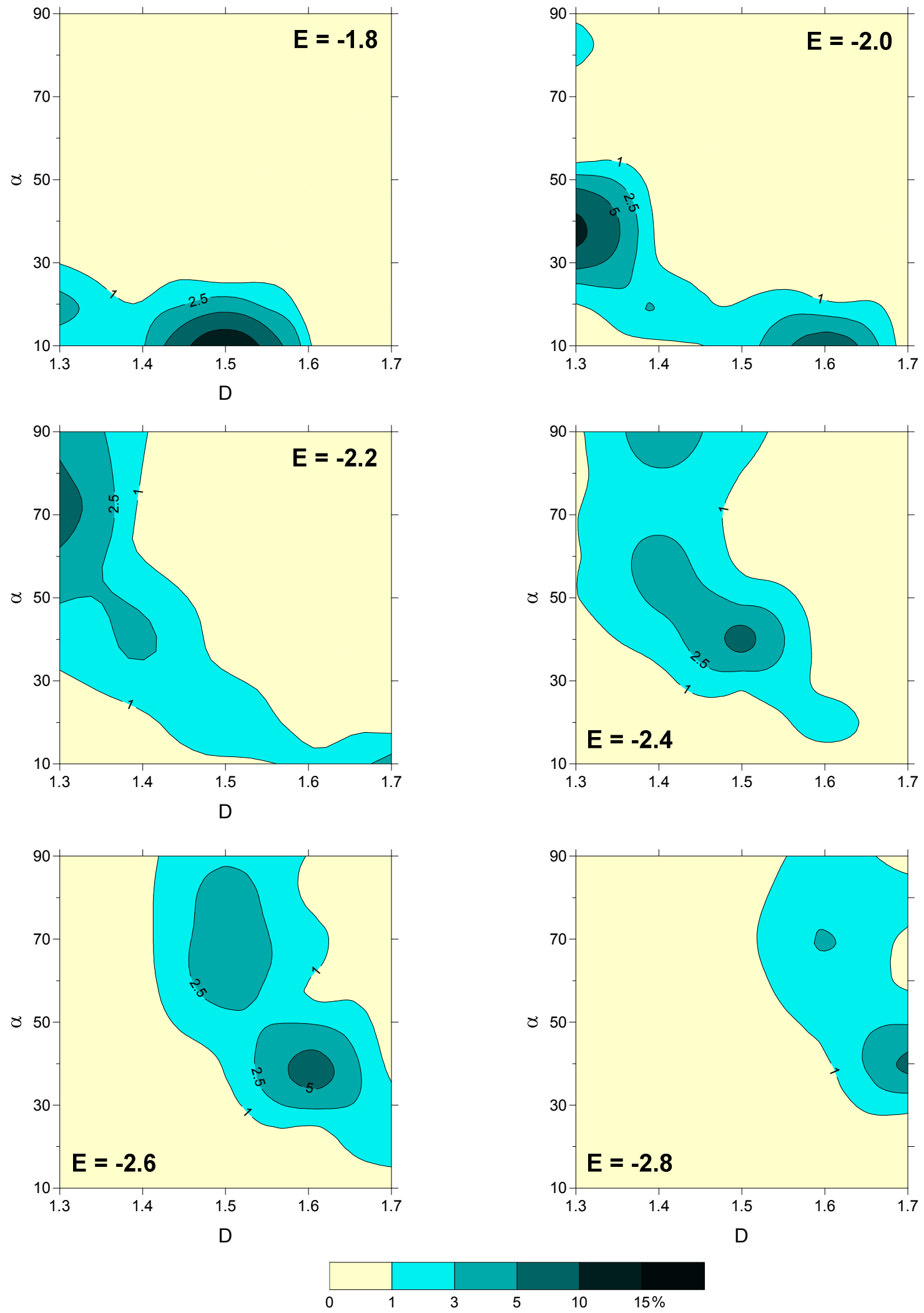

7. sorozat: a $D$ és $\alpha$ paraméterek változásának hatása a második legnagyobb perkolációs klaszter relatív méretére 

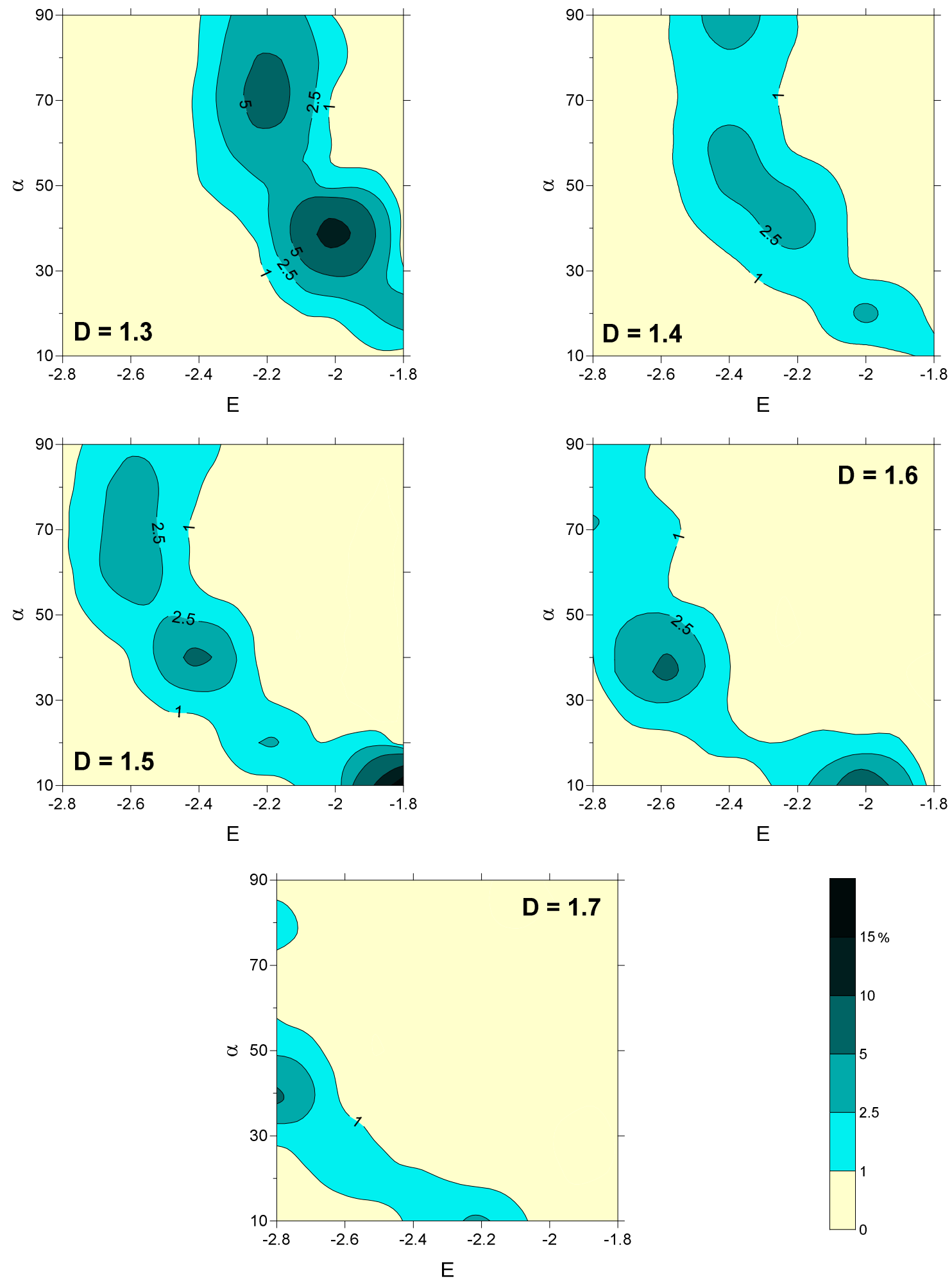

8. sorozat: az $E$ és $\alpha$ paraméterek változásának hatása a második legnagyobb perkolációs klaszter relatív méretére 

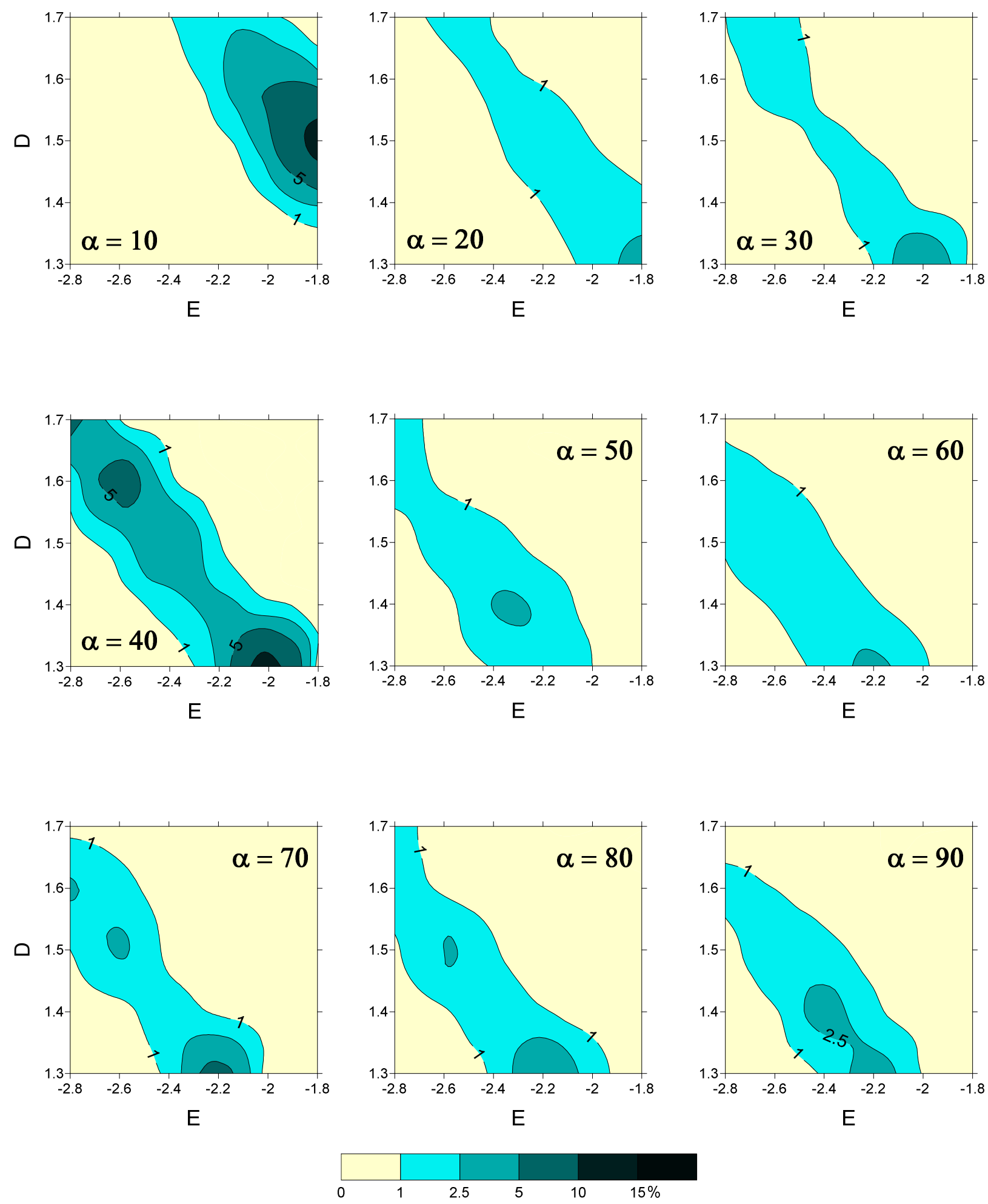

9. sorozat: az $E$ és $D$ paraméterek változásának hatása a második legnagyobb perkolációs klaszter relatív méretére 
D. melléklet: a relatív dőlés számítására íródott Visual Basic program forráskódja

Public Class szamolas

Public Shared Function szamol(ByVal alf1 As Double, ByVal bet1 As Double, ByVal alf2 As Double, ByVal bet2 As Double) As Double

$$
\begin{aligned}
& \text { alf1 }=\text { alf1 } *(2 * \mathrm{PI}) / 360 \\
& \text { alf2 }=\text { alf2 }{ }^{*}\left(2{ }^{*} \mathrm{PI}\right) / 360 \\
& \text { bet1 }=\text { bet1 }{ }^{*}\left(2{ }^{*} \mathrm{PI}\right) / 360 \\
& \text { bet2 }=\text { bet2 }{ }^{*}\left(2{ }^{*} \mathrm{PI}\right) / 360
\end{aligned}
$$

'Csapásirány megadása: dőlésirány - 90 fok

$$
\begin{aligned}
& \operatorname{Dim} A 1=\operatorname{Cos}(\text { alf1 }) *(-\operatorname{Tan}(\text { bet1) }) \\
& \operatorname{Dim} A 2=\operatorname{Cos}(\text { alf2 }) *(-\operatorname{Tan}(\text { bet2) }) \\
& \operatorname{Dim~B1}=(\operatorname{Sin}(\text { alf1 }) *(-\operatorname{Tan}(\text { bet1) })) \\
& \operatorname{Dim~B2}=(\operatorname{Sin}(\text { alf2 }) *(-\operatorname{Tan}(\text { bet2) }))
\end{aligned}
$$

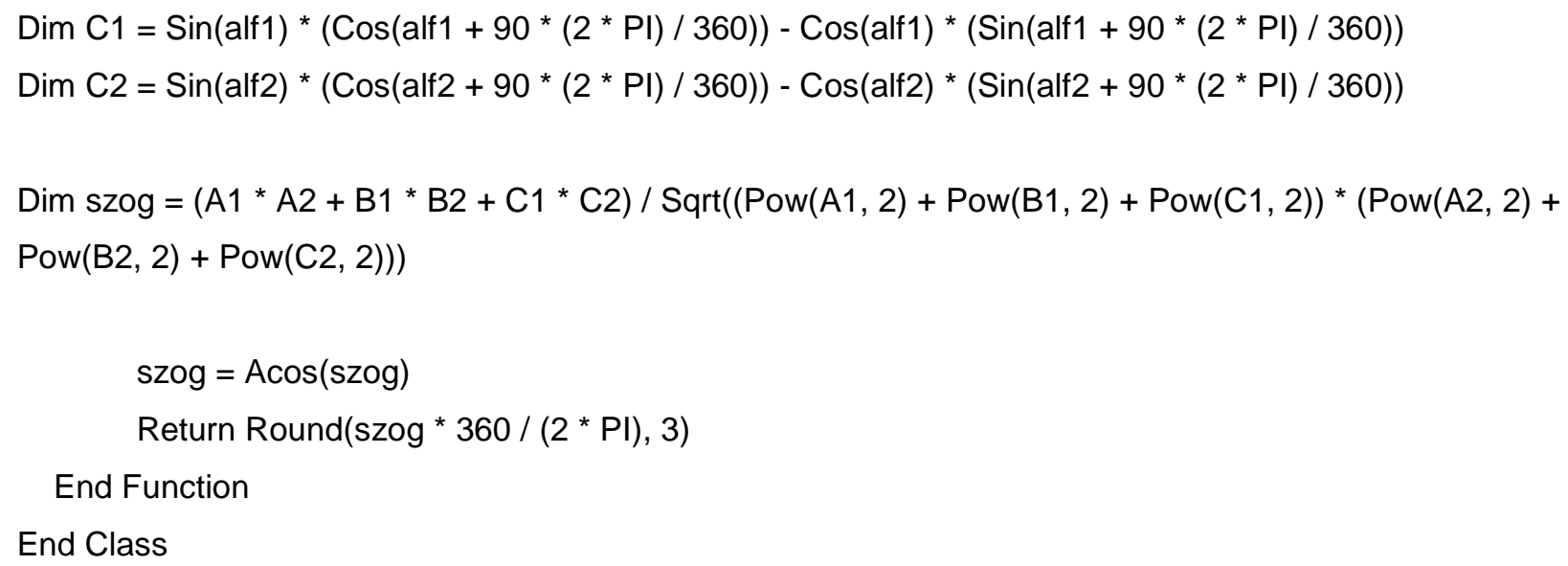


$\boldsymbol{E}$. melléklet: A véges differencia és végeselemes modellek hidrodinamikai és hőtranszport paraméterei

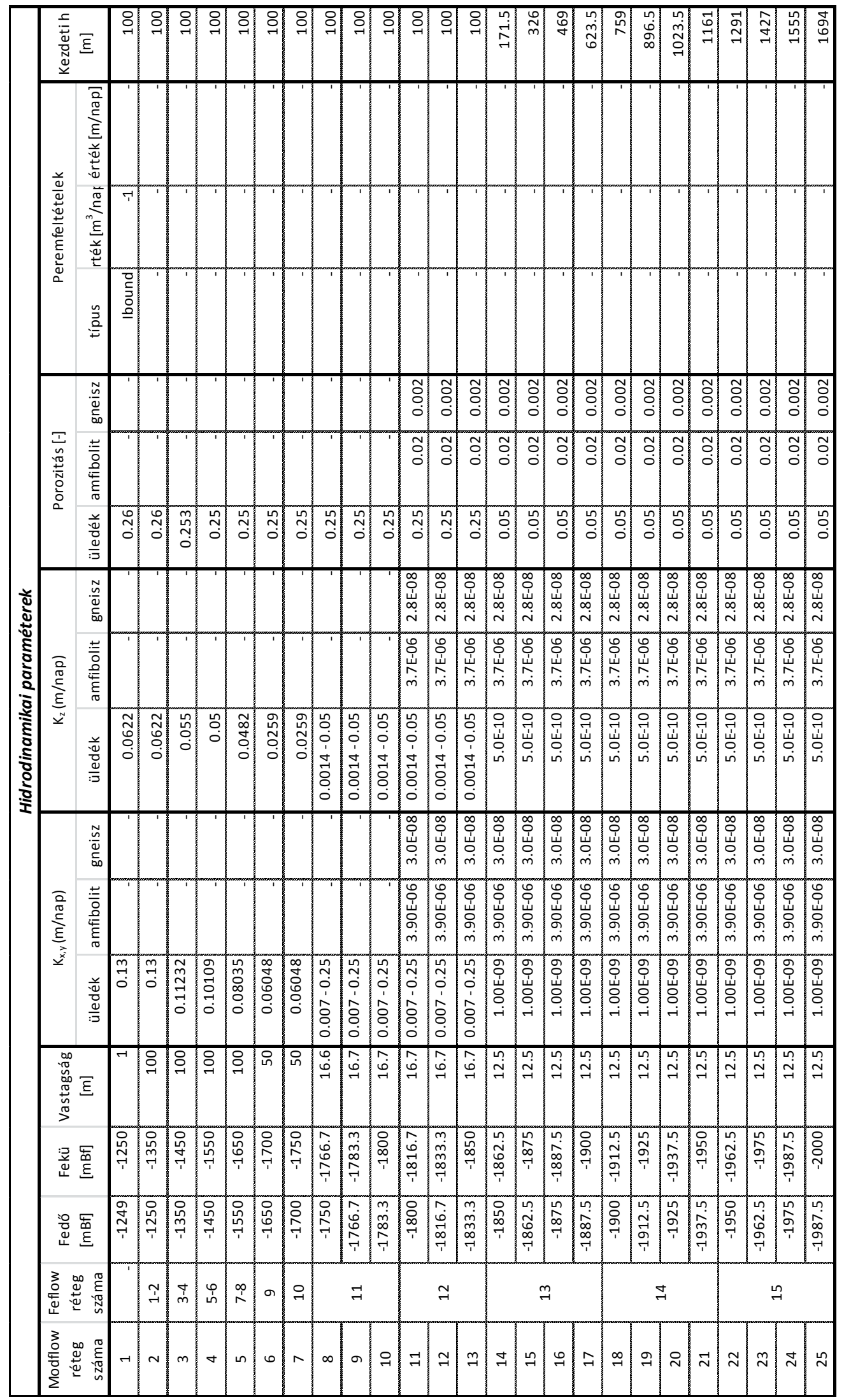




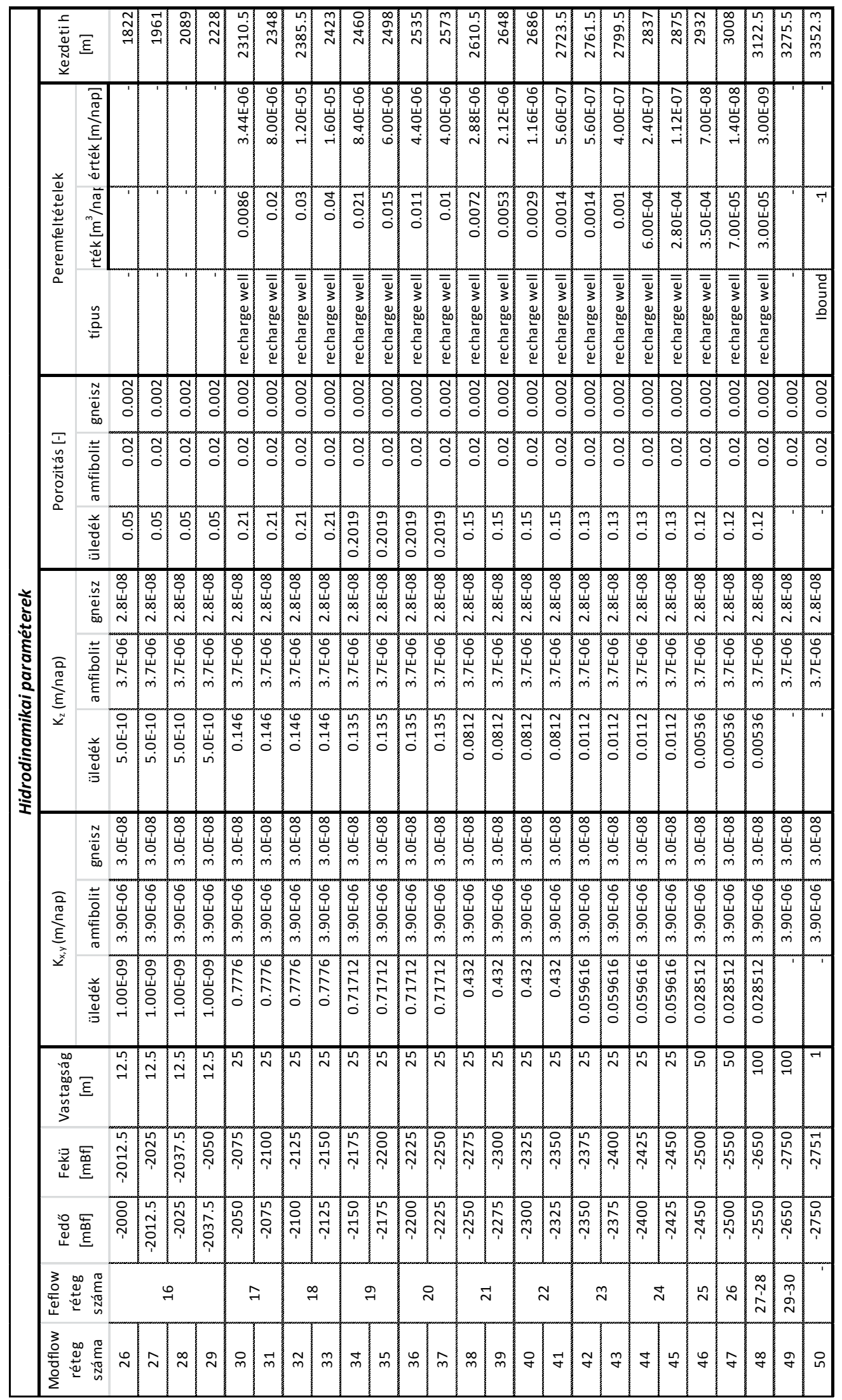




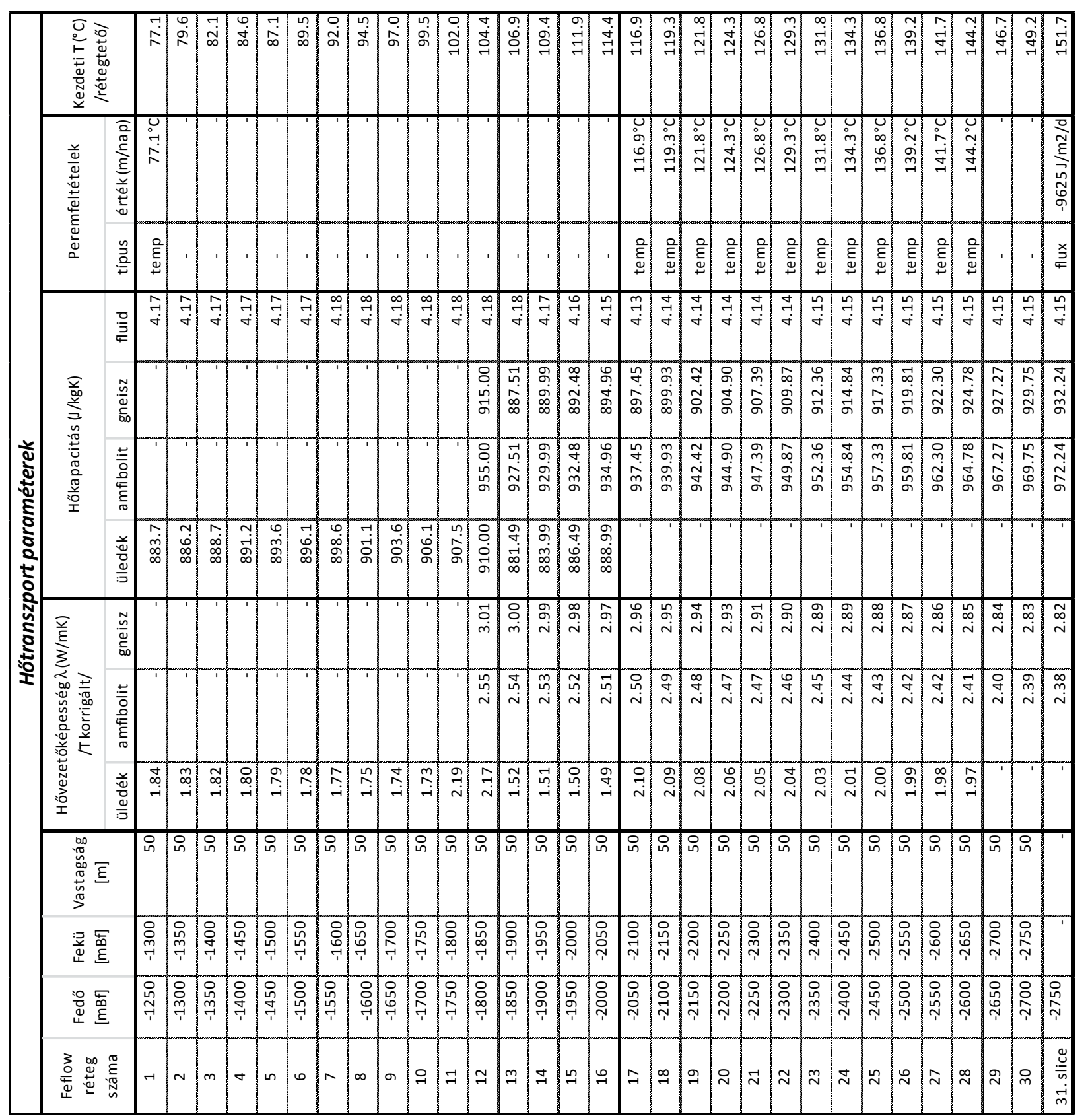


$\boldsymbol{F}$. melléklet: a konduktív és konvektív hőterjedés arányának analitikus számítása az aljzati magaslat központi részén

\begin{tabular}{|c|c|c|c|c|}
\hline$\rho_{1}$ & $=$ & 956 & $\mathrm{~kg} / \mathrm{m}^{3}$ & Fluidum sủrüsége a nyomásátmeneti zóna tetején $\left(108^{\circ} \mathrm{C}\right)$ \\
\hline$\rho_{2}$ & $=$ & 960 & $\mathrm{~kg} / \mathrm{m}^{3}$ & Fluidum sűrüsége a nyomásátmeneti zóna alján $\left(118^{\circ} \mathrm{C}\right)$ \\
\hline$\rho_{\text {átl }}$ & $=$ & 958 & $\mathrm{~kg} / \mathrm{m}^{3}$ & Fluidum átlagsűrüsége a nyomásátmeneti zónában \\
\hline$c_{\mathrm{p} 1}$ & $=$ & 4185 & $\mathrm{~J} / \mathrm{kg}^{\circ} \mathrm{C}$ & Fluidum fajlagos hőkapacitása a nyomásátmeneti zóna tetején \\
\hline$c_{\mathrm{p} 2}$ & $=$ & 4152 & $\mathrm{~J} / \mathrm{kg}^{\circ} \mathrm{C}$ & Fluidum fajlagos hőkapacitása a nyomásátmeneti zóna alján \\
\hline$c_{p}$ átl & & 4169 & $\mathrm{~J} / \mathrm{kg}^{\circ} \mathrm{C}$ & Fluidum átlagos fajlagos hőkapacitása a nyomásátmeneti zónában \\
\hline $\mathrm{K}$ & $=$ & $2,08 \cdot 10^{-10}$ & $\mathrm{~m} / \mathrm{s}$ & Aljzat szivárgási tényezője (hőmérséklettel korrigált átlag) \\
\hline$\lambda$ & $=$ & 2,52 & $\mathrm{~W} / \mathrm{m}^{\circ} \mathrm{C}$ & Aljzat hővezetőképessége (hőmérséklettel korrigált átlag) \\
\hline $\mathrm{p}_{1}$ & $=$ & 190 & bar & Nyomás nagysága -1850 m-ben \\
\hline $\mathrm{p}_{2}$ & $=$ & 409,5 & bar & Nyomás nagysága -2050 m-ben \\
\hline $\mathrm{L}$ & $=$ & 200 & $\mathrm{~m}$ & Túlnyomásos és gravitációs rezsim közötti átmeneti zóna hossza \\
\hline$\Delta \mathrm{h}$ & $=$ & 2335,6 & $\mathrm{~m}$ & Az átmeneti zóna teteje és alja közötti potenciál-különbség \\
\hline
\end{tabular}

$$
P_{e}=R_{e} \cdot P_{r}=\frac{\rho \cdot K \cdot \Delta h}{\mu} \cdot \frac{c_{p} \cdot \mu}{\lambda}=\frac{K \cdot \rho \cdot c_{p} \cdot \Delta h}{\lambda}=\frac{2,08 \cdot 10^{-10} \cdot 958 \cdot 4169 \cdot 2335,6}{2,52}=0,77
$$

